\title{
CITY OF SAN LUIS OBISPO \\ MONITORING PROGRAM AND PROCEDURES FOR INCLUSIONARY HOUSING
}

\author{
A Professional Project \\ presented to \\ the Faculty of California Polytechnic State University, \\ San Luis Obispo
}

\author{
In Partial Fulfillment \\ of the Requirements for the Degree \\ Master of City and Regional Planning
}

by

Shannon Marie Blomst

June 2012 
(C) 2012

Shannon Marie Blomst

ALL RIGHTS RESERVED

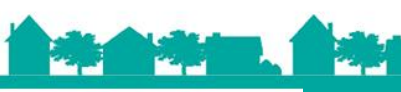




\section{COMMITTEE MEMBERSHIP}

TITLE: $\quad$ City of San Luis Obispo: Monitoring Program and Procedures for Inclusionary Housing

AUTHOR: $\quad$ Shannon Marie Blomst

DATE SUBMITTED: June 2012

COMMITTEE CHAIR: Hemalata Dandekar, CRP Department Head, Professor

COMMITTEE MEMBER: Umut Toker, Associate Professor

COMMITTEE MEMBER: Tyler Corey, Housing Programs Manager, City of San Luis Obispo 


\section{ABSTRACT}

City of San Luis Obispo: Monitoring Program and Procedures for Inclusionary Housing

\section{Shannon Marie Blomst}

The Monitoring Program for all Inclusionary housing units in the City of San Luis Obispo is a needed component to the Affordable Housing Program. It ensures eligible households are occupying the affordable units and those that are renting are being charged according to the Affordable Housing Standards. Within the City's Municipal Code it specifies monitoring and management of inclusionary units shall be done, however this hasn't happened until now.

This professional project provides a needed analysis of the current affordable housing stock. It examines multiple case studies that look at exemplary designed affordable housing units as well as implemented monitoring programs, which serve as a guide to the City of San Luis Obispo's monitoring program. An extensive assessment survey was administered to all the inclusionary units within the City of San Luis Obispo that included some questions pertaining to the quality and design of the current units, location to local services, primary mode of transportation and miles traveled to work. The analysis of the survey responses were compiled into different analyzed categories: overall, senior, owner and renter. The analysis information and monitoring program procedures manual were completed as deliverables to the City of San Luis Obispo. The project concludes with recommendations for future affordable housing developments and toolkits, including the monitoring program procedures manual, to help with preservation of the current housing stock and ensure quality and sustainable affordable housing projects.

Keywords: Monitoring Program, Inclusionary, Affordable Housing Program, Assessment Survey, Toolkits, Procedures Manual 


\section{ACKNOWLEDGMENTS}

I express my sincerest appreciation to my committee chair Professor and CRP Department Head, Hemalata Dandekar for her invaluable guidance, insightful feedback, willingness to answer questions and fun times conversing about our personal lives.

I am especially appreciative of Tyler Corey, Housing Programs Manager for the City of San Luis Obispo and committee member, for providing me with the opportunity to pursue this project. Without his guidance and constant willingness to answer questions, this work would not have been possible. His patience and enthusiasm were greatly appreciated throughout the completion of this project.

I would also like to extend my appreciation to Umut Toker, Associate Professor and committee member, for his knowledge and guidance regarding community participation through surveys. I would like to thank him for his feedback on relevant questions to be asked of the community.

I extend a special thank you to my husband, Andreas for his unwavering support and patience as I worked on this project. Without his encouragement and needed distractions I would not have been able to complete this work.

Finally, I thank my family and my Papa for always standing behind me and supporting my efforts. Their daily encouragement was greatly appreciated. 


\section{Table of Contents}

LIST OF TABLES .......................................................................................................... ix

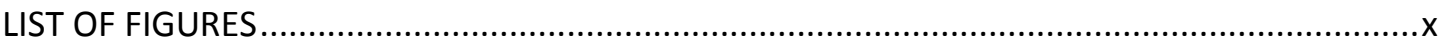

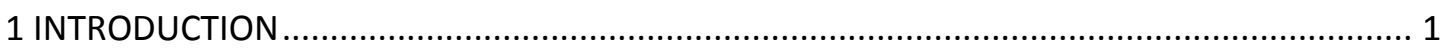

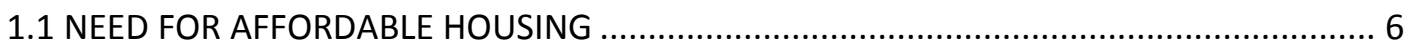

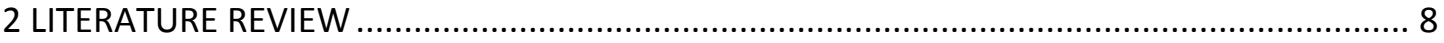

2.1 HISTORY OF AFFORDABLE HOUSING IN THE U.S …………................................. 8

2.2 POST OCCUPANCY EVALUATIONS FOR AFFORDABLE HOUSING .................................. 9

2.3 DESIGN STIGMA SURROUNDING AFFORDABLE HOUSING........................................ 13

2.3.1 Why Design Matters ...................................................................................... 14

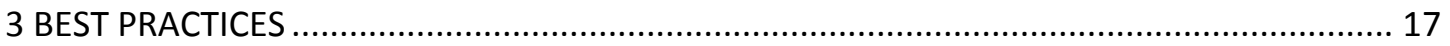

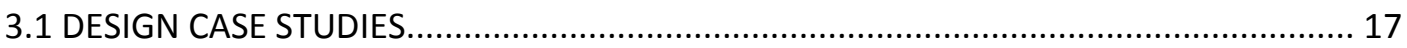

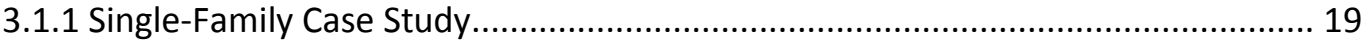

3.1.2 Senior Center Case Study .......................................................................... 20

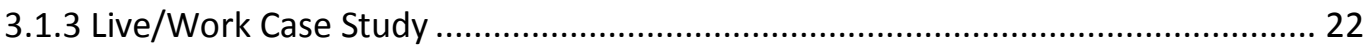

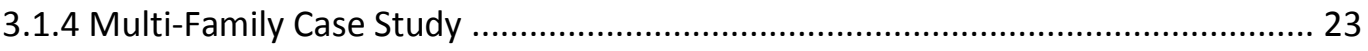

3.1.5 Traditional Approach to Affordable Housing Design-Senior Center....................... 26

3.1.6 Traditional Approach to Affordable Housing Design-Multi-Family ....................... 27

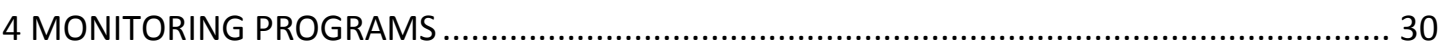

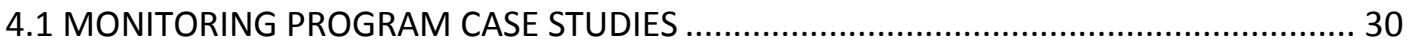

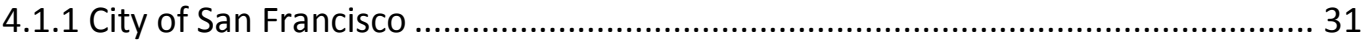

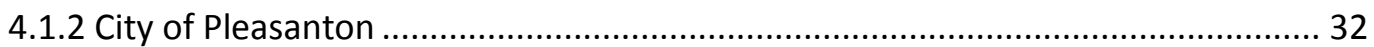

4.1.3 Santa Barbara County Monitoring Program …………………………………..... 32

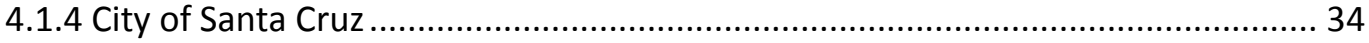

5 ASSESSMENT OF THE CURRENT AFFORDABLE HOUSING STOCK.......................................... 36

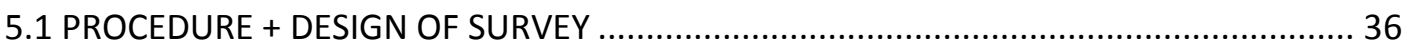

5.2 ARCHITECTS KEY ELEMENTS IN DESIGN ............................................................ 38

5.3 PLANNERS KEY ELEMENTS IN DESIGN .................................................................. 41

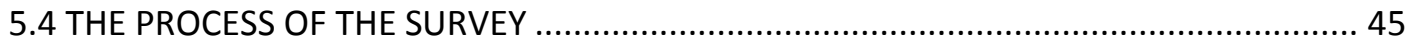




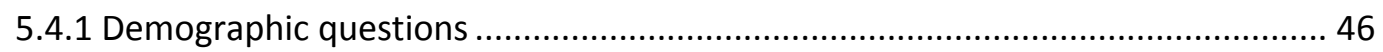

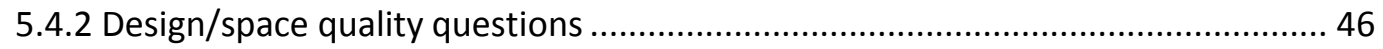

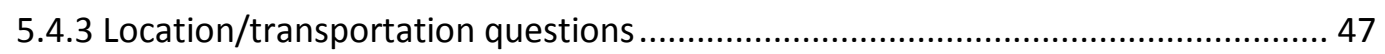

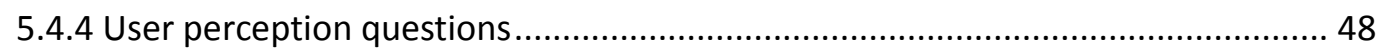

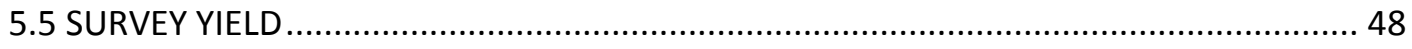

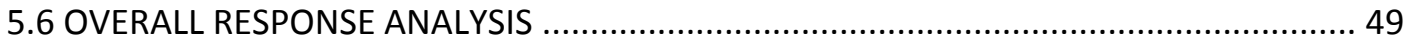

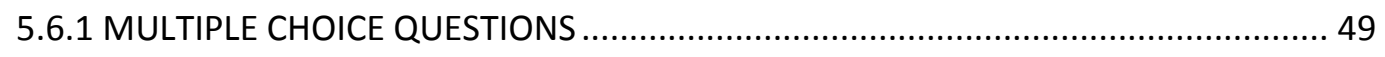

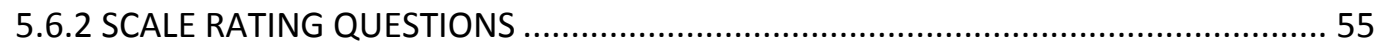

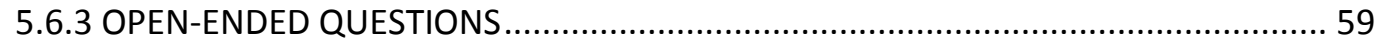

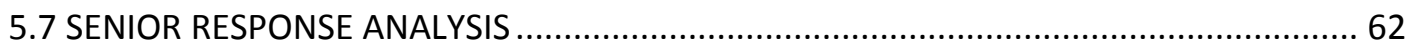

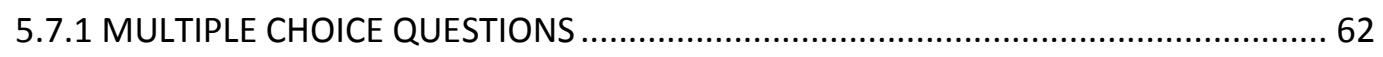

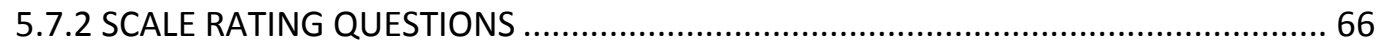

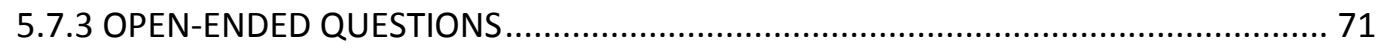

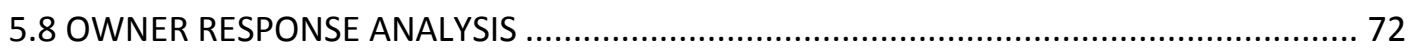

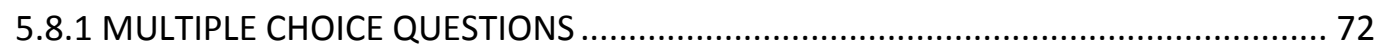

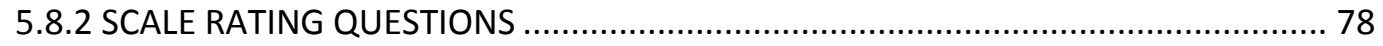

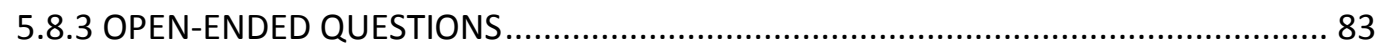

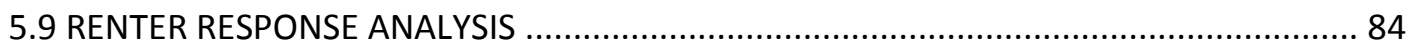

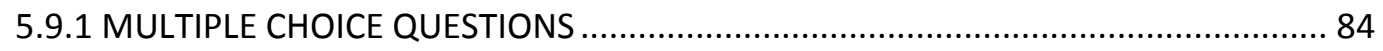

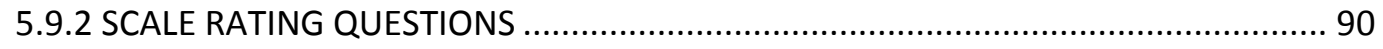

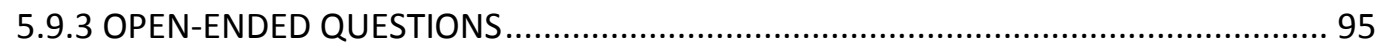

5.10 BEST LOCATIONS FOR AFFORDABLE HOUSING IN SAN LUIS OBISPO .......................... 97

5.11 DESIGN RECOMMENDATIONS FOR AFFORDABLE HOUSING IN SAN LUIS OBISPO.. 105

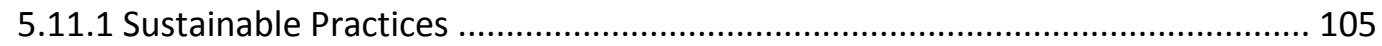

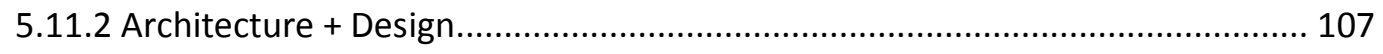

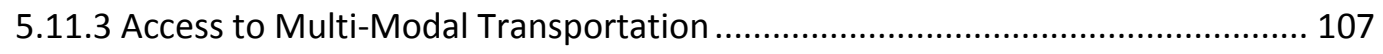

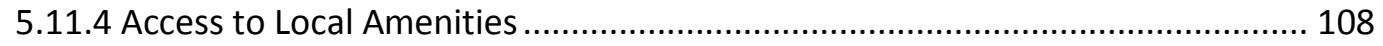

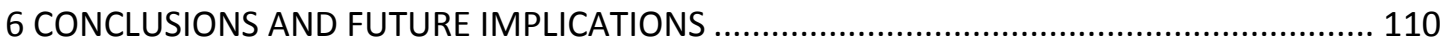

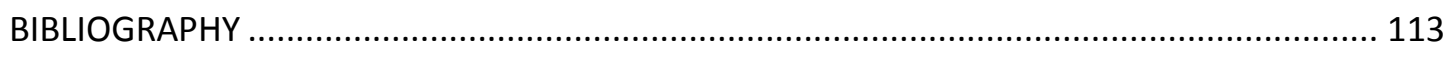

APPENDIX A: MONITORING PROGRAM PROCEDURES MANUAL(Deliverable to the City of

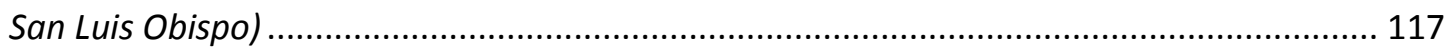

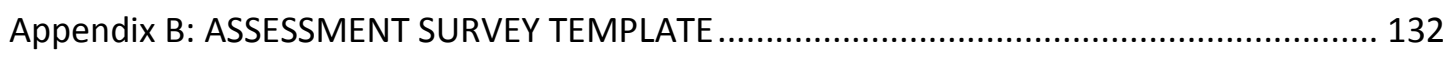


Appendix C: COMPLIANCE SURVEY TEMPLATE (Side One).

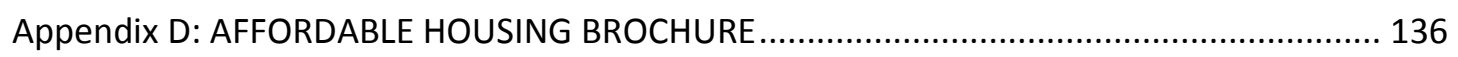

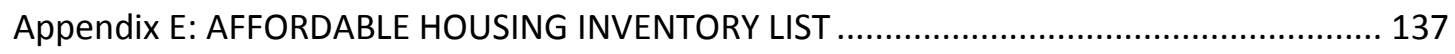

Appendix F: CITY OF SANTA MONICA GREEN AFFORDABLE HOUSING CHECKLIST .............. 138

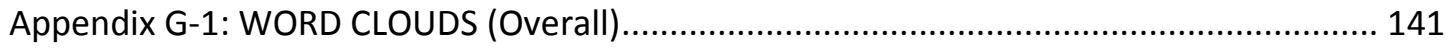

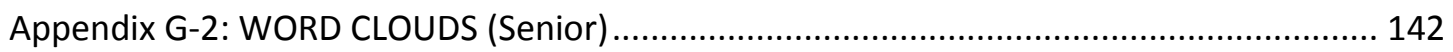

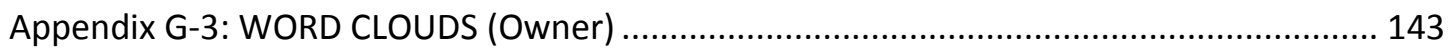

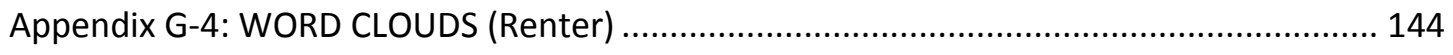

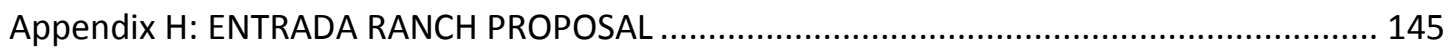




\section{LIST OF TABLES}

TAble 1. Results from AsSESSment SURVey rating Air Quality, Ventilation, Natural Lighting and HEATING/COOLING OF ONE'S HOME. 


\section{LIST OF FIGURES}

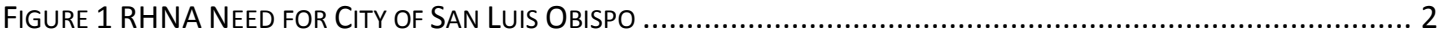

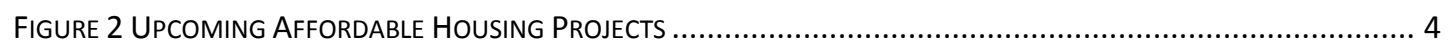

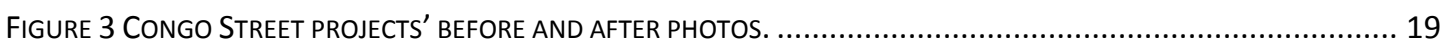

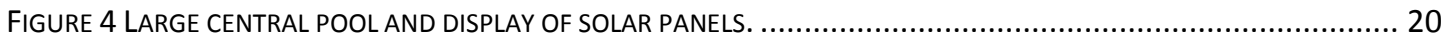

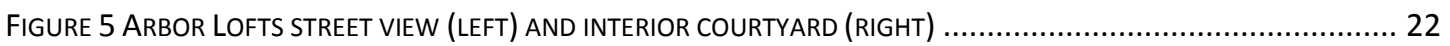

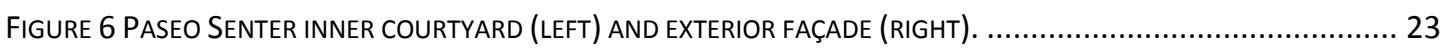

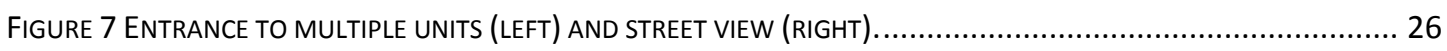

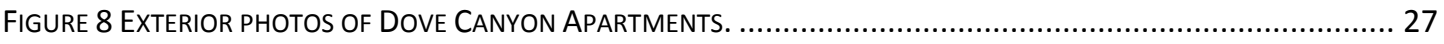

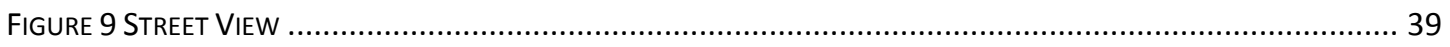

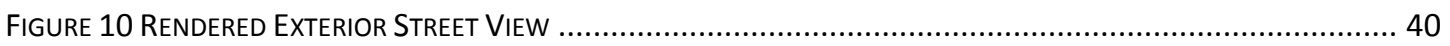

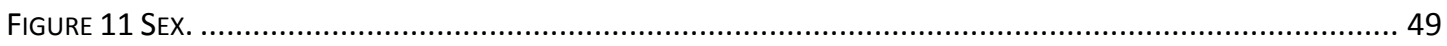

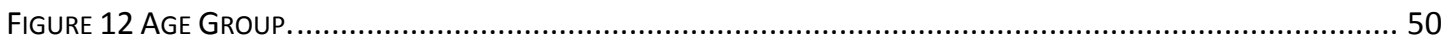

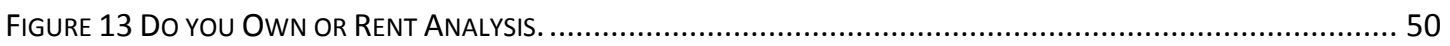

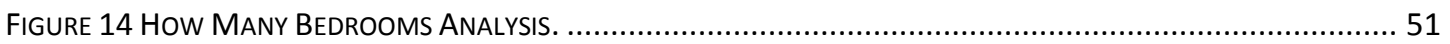

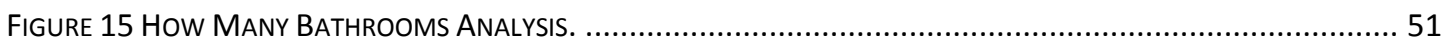

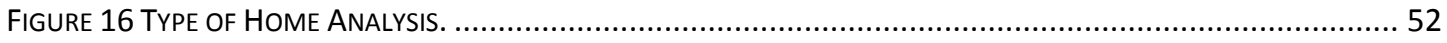

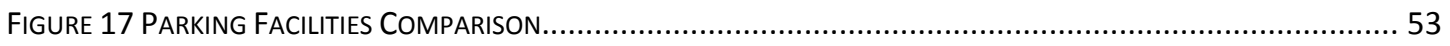

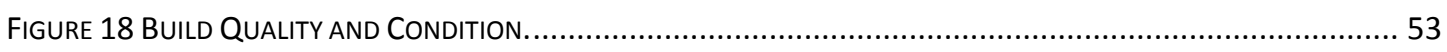

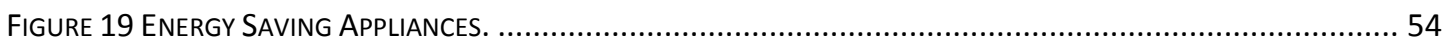

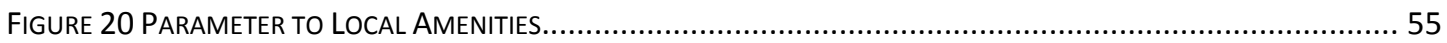

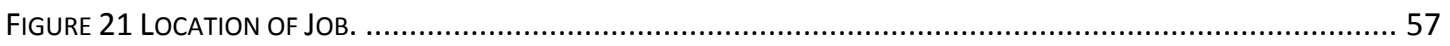

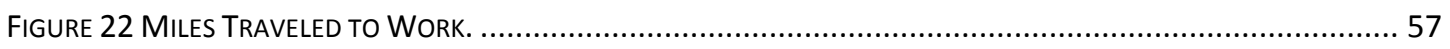

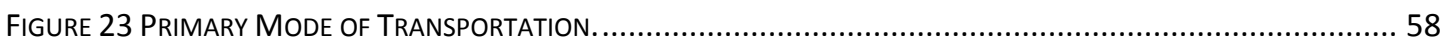

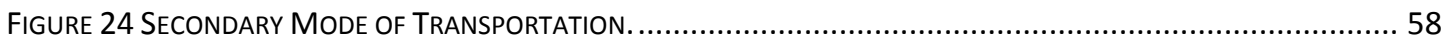

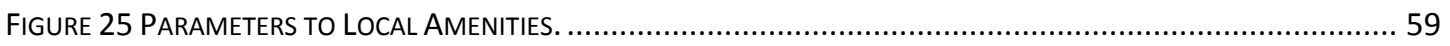

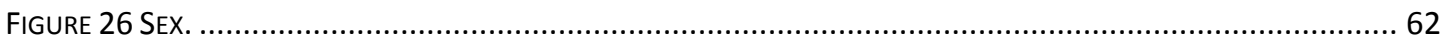

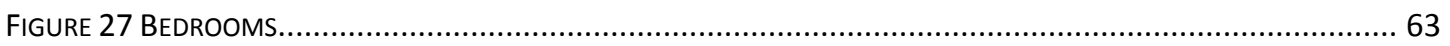

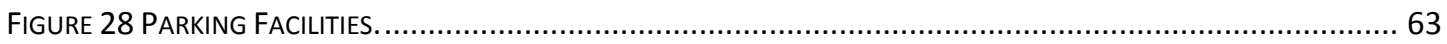

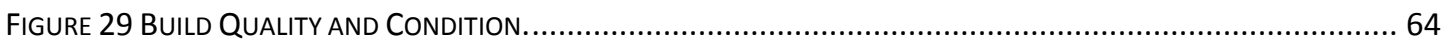

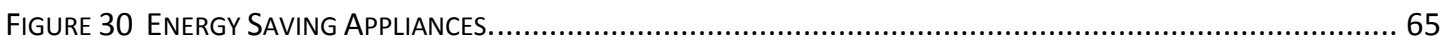

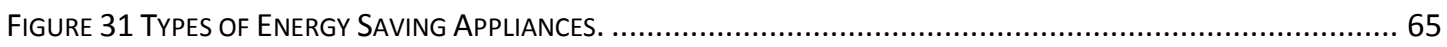

FIGURE 32 HOURS SPENT IN SPACES OF THE HOME.

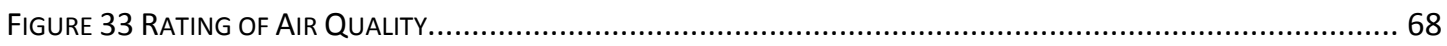

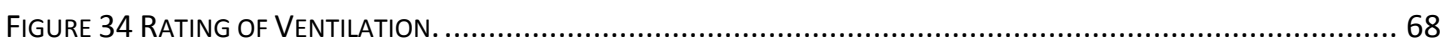

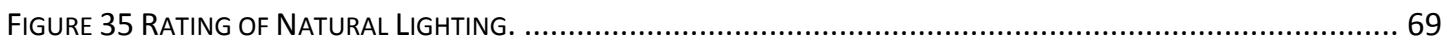

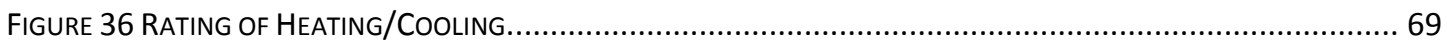

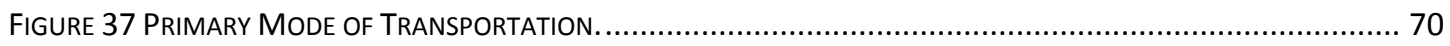

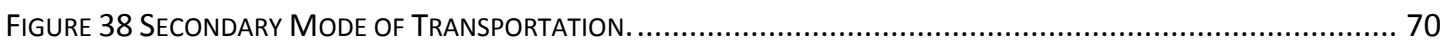

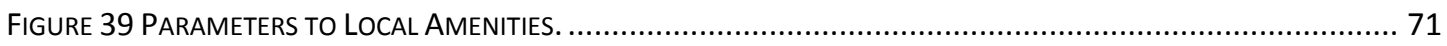

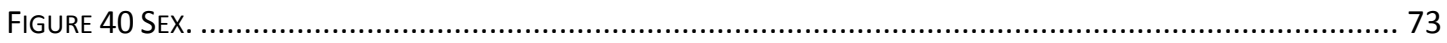

FIGURE 41 AGE GROUP

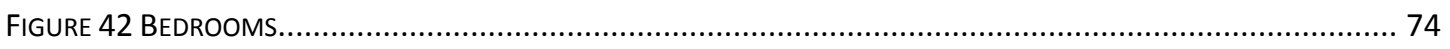

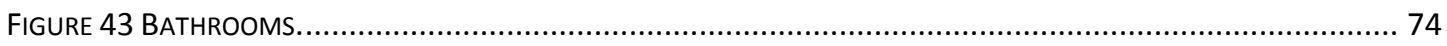

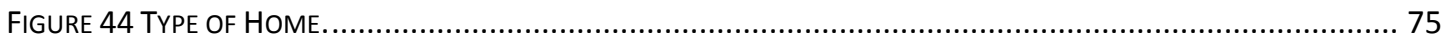

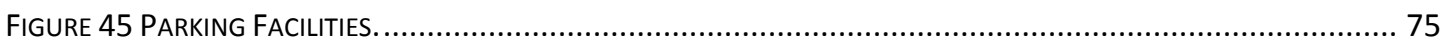




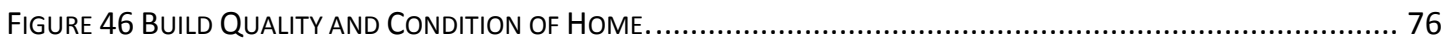

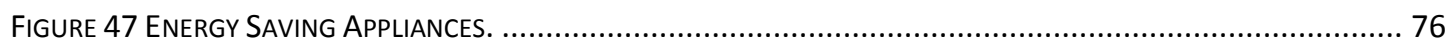

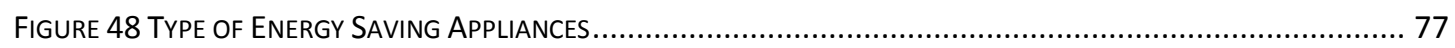

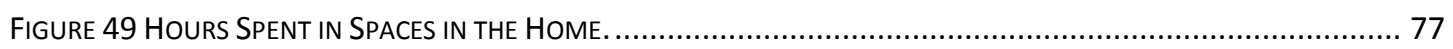

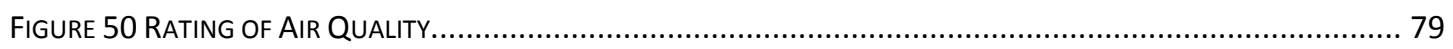

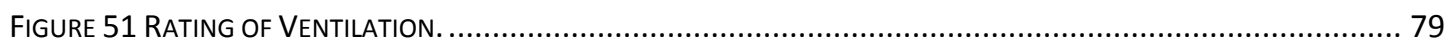

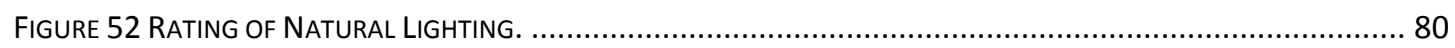

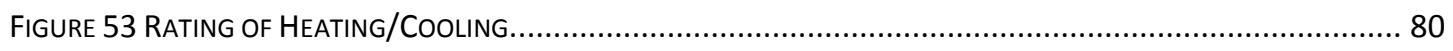

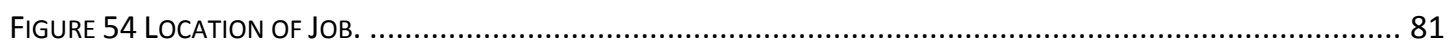

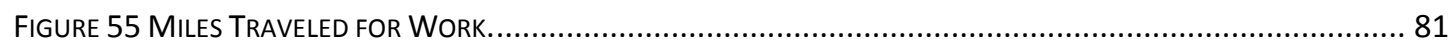

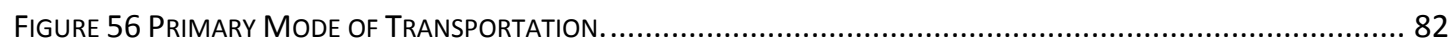

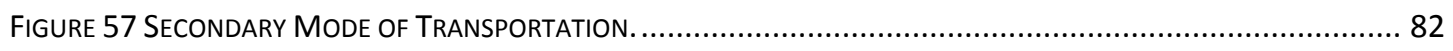

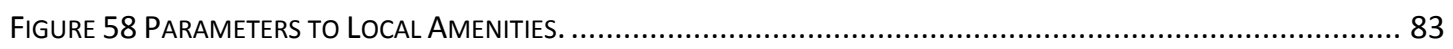

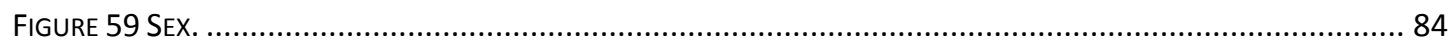

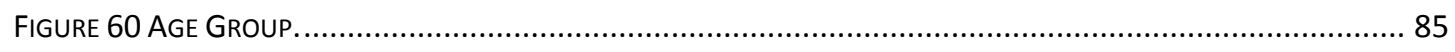

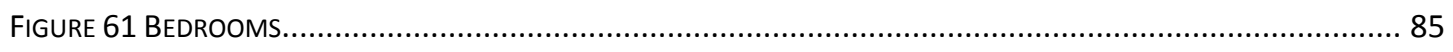

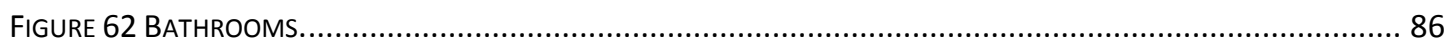

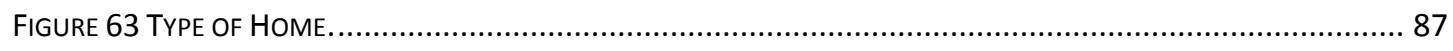

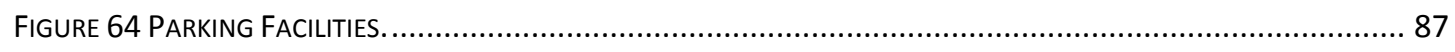

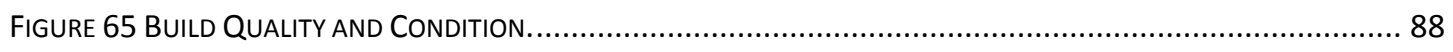

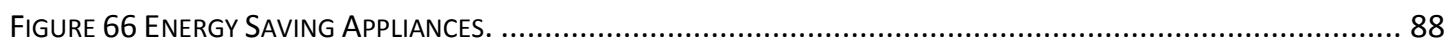

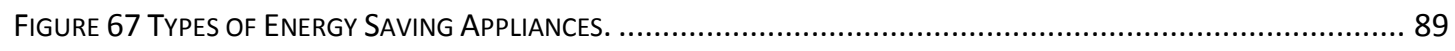

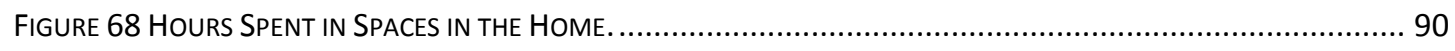

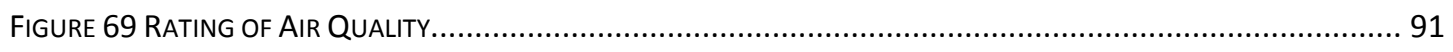

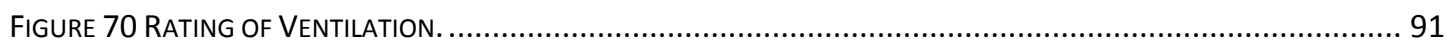

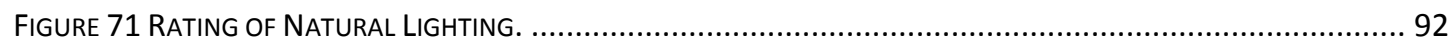

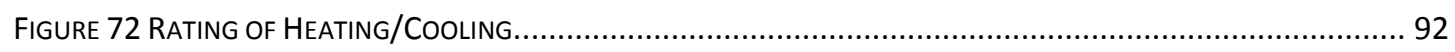

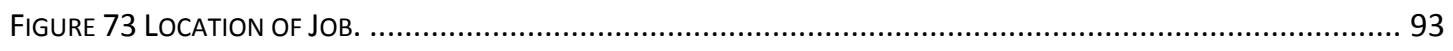

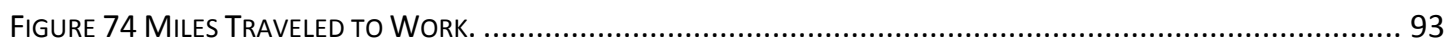

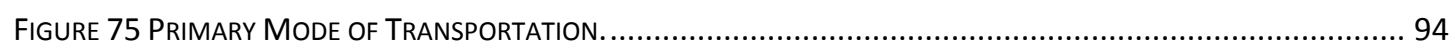

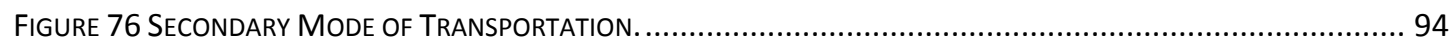

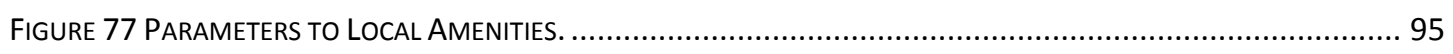

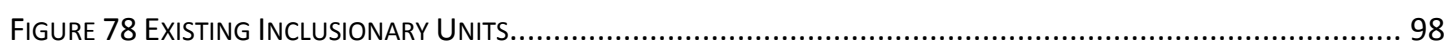

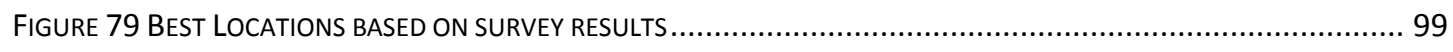

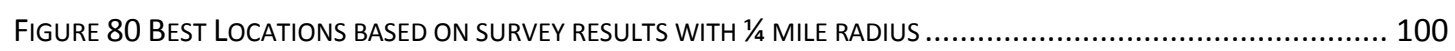

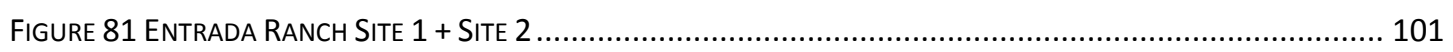

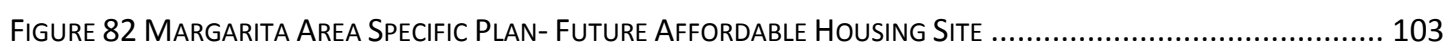

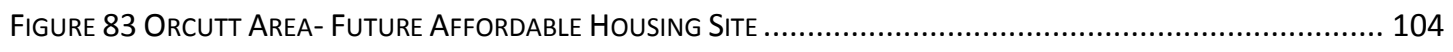




\section{INTRODUCTION}

Millions of people across the United States find themselves struggling to afford a roof over their head. Many are spending well over the 30 percent of their annual income on rent, which according to the U.S. Department of Housing and Urban Development (HUD) standards, is a rent-burden. About 12 million renter and homeowner households are paying 50 percent of their income for housing. The lack of affordable housing for the lower income households makes it difficult to afford housing as well as other everyday basic needs. The affordability gap is increasing throughout the United States, with the lack of jobs and a decline in the creation of new jobs. In order to achieve a perfectly balanced housing market that provides homes to people in all income strata, a dramatic increase of affordable housing catering to the needs of families in lower income groups is needed.

According to Tyler Corey the Housing Programs Manager of the City of San Luis Obispo, "The City's Inclusionary Housing program was initiated in 1999 to increase the production and availability of affordable housing citywide. Prior to the effective date of the Ordinance, there was no formal requirement that developers include affordable housing in their projects or 
pay an in-lieu fee to the City to assist with affordable housing development and rehabilitation."

Despite the ordinance, the City of San Luis Obispo currently still needs more affordable housing. According to the City's Housing Element, the City currently has some 45,000 residents and more than 30,000 people commuting into the City of San Luis Obispo during the work week. The housing prices are much higher than the surrounding cities, so many cannot afford to live in San Luis Obispo and must choose to commute five days a week for work.

The City's Regional Housing Needs Allocation (RHNA) clearly displays in Table 6 of the Housing Element, the need for affordable housing, especially in the very-low income category (Housing Element, 2010, pg.64).

\section{Figure 1 RHNA Need for City of San Luis Obispo}

Remaining RHNA Need Based on Dwelling Units Approved, Under Construction or Built, January 1, 2007 to December 31, 2009

\begin{tabular}{|c|c|c|c|}
\hline & $\mathbf{A}$ & B & A-B \\
\hline Income Category & $\begin{array}{c}\text { New } \\
\text { Construction } \\
\text { Need (RHNA) }\end{array}$ & $\begin{array}{c}\text { Dwelling Units } \\
\text { Approved, Under } \\
\text { Construction or Built }\end{array}$ & $\begin{array}{c}\text { Remaining Need, } \\
\text { Dwelling Units }\end{array}$ \\
\hline $\begin{array}{l}\text { Extremely-Low } \\
(<31 \% \text { of AMI })\end{array}$ & 185 & 8 & 177 \\
\hline $\begin{array}{c}\text { Very Low (31-50\% of } \\
\text { AMI) }\end{array}$ & 185 & 164 & 21 \\
\hline $\begin{array}{c}\text { Low }(51-80 \% \text { of } \\
\text { AMI })\end{array}$ & 259 & 32 & 227 \\
\hline $\begin{array}{c}\text { Moderate }(81-120 \% \\
\text { of AMI) }\end{array}$ & 295 & 42 & 253 \\
\hline $\begin{array}{c}\text { Above Moderate } \\
\text { (over } 120 \% \text { of AMI) }\end{array}$ & 665 & $1,033^{1}(665)$ & $0^{1}$ \\
\hline TOTAL UNITS & 1,589 & $1,279(911)$ & 678 \\
\hline
\end{tabular}

Source: City of San Luis Obispo Community Development Department, 2010

${ }^{1}$ No credit allowed for the number of units built that exceed RHNA. 
Every state has a mandated Regional Housing Needs Allocation (RHNA). The RHNA quantifies the need for housing within each jurisdiction during specified planning periods. To help in this housing gap the City has several affordable housing projects in the pipeline. There are over 200 affordable units in the works. One hundred and twenty of the 200 are part of a rehabilitation project on Madonna Road, whereas others are in the approval process located on Nipomo Street, Humbert Ave, Rockview Place and Orcutt Street. 
Figure 2 Upcoming Affordable Housing Projects

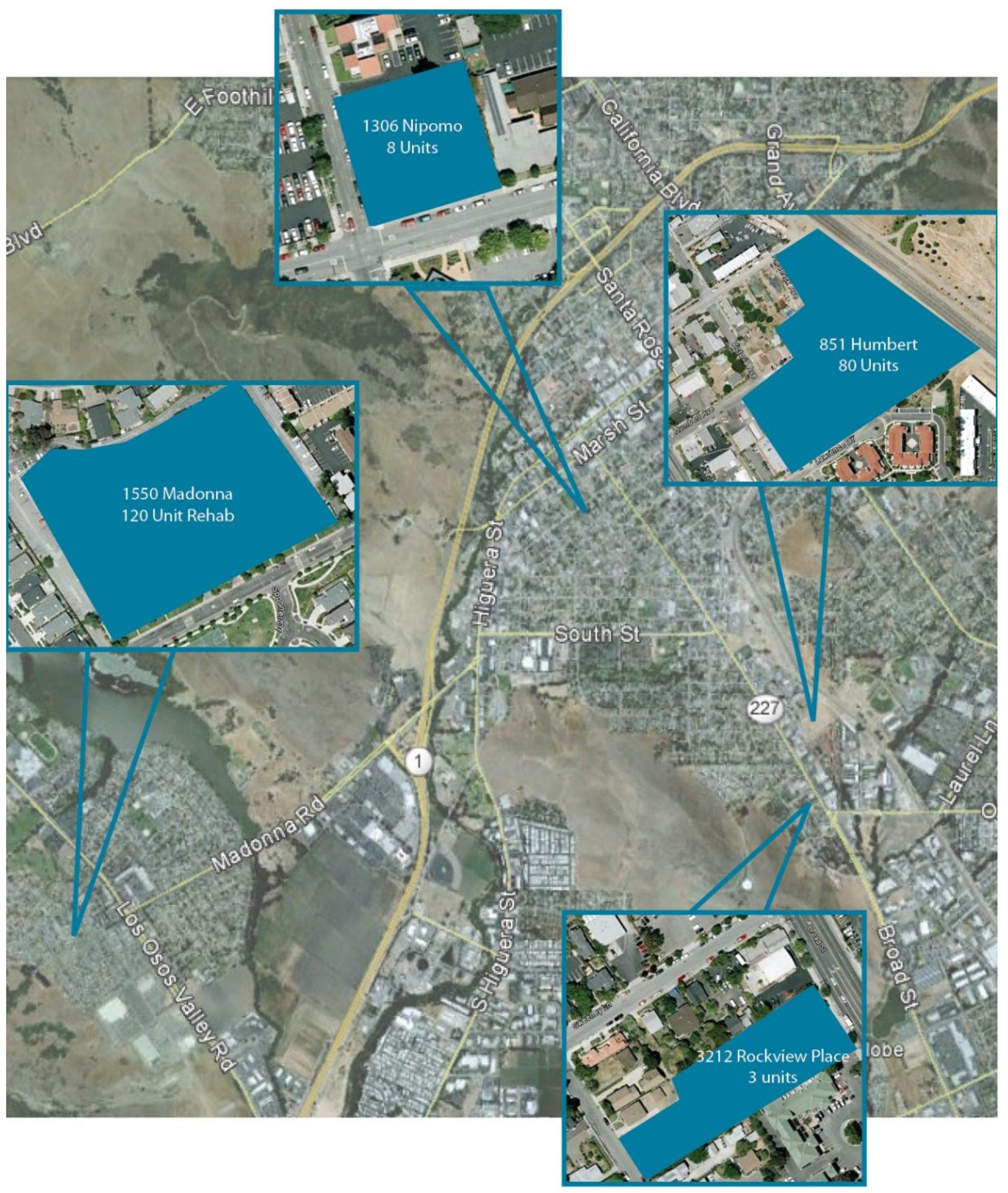


The City of San Luis Obispo currently has 230 inclusionary housing units, 50 are owner occupied and 180 are renter occupied. One difference between the stipulations for an owner and renter occupied unit is the affordability period. The owner must occupy the ownership units at all times and the affordability period, is currently 45 years. The owners of the affordable units may sell the unit before the affordability period expires, but it must be sold to an eligible household. An eligible household consists of one who receives income certification through a qualified non-profit organization. The income certifications are required for owner occupied units in order to ensure they qualify to own an affordable unit. The owner's cost for the income certification is $\$ 350$. The sale of a unit and other stipulations must be consistent with the Affordable Housing Standards (slocity.org/communitydevelopment/housing), which are based on income limits and number of bedrooms within the dwelling unit. The sale prices of the owner occupied units are determined by the City. They base the prices off of the information received from the state and use particular calculations to determine the maximum sales prices for the affordable units. Every year these standards are updated and generally reflect a 1-2\% increase, which in turn can generate a small increase in equity for an affordable unit.

The renter occupied units must also be occupied by an eligible renter, but the affordability period is 55 years. The rental rates are determined by the Affordable Housing Standards and are based on the income level of the unit and number of bedrooms. These rental rates are set by the City, but carried 
out by the property management company overseeing the property. For example if the rental unit is a two-bedroom, very-low income unit the rent is set to not exceed \$848. (Affordable Housing Standards 2012). In order to ensure the City's effort to create a sound affordable housing program that is in conformance with these rules and regulations, a monitoring system and/or program is needed. This project moves the City forward in developing a proposed evaluation and monitoring effort that ensures the City's affordable units comply with the City's affordability agreements and that affordable housing projects are designed to preserve and establish affordable housing for the community.

\subsection{NEED FOR AFFORDABLE HOUSING}

The City of San Luis Obispo does not have a monitoring program or procedure. The development of a compliance program will help track both compliant and noncompliant affordable units and fill the need for information to support an assessment of the effectiveness of the program. The need for a monitoring program is listed in the Housing Element, under goal 3: "Housing Conservation, which will establish a monitoring and early warning system to track affordable housing units at-risk of being converted to market rate housing" and the Inclusionary Housing Requirements 17.91.160 (Management and Monitoring), which states: "inclusionary rental units shall be managed and operated by the property owner, or the owner's agent, for the term of the Affordable Housing Agreement". Sufficient documentation shall be submitted to ensure compliance with this chapter, to the satisfaction 
of the Director. Implementation of a monitoring program for the City of San Luis Obispo will allow a biennial measure of compliance for the inclusionary units and provide a process for both renter and owner occupied units, to correct agreement violations. In order to evaluate possible reasons to why units are out of compliance, further investigation and an assessment will be done on those units that are deemed non-compliant through a POE (Post Occupancy Evaluation) and/or Design Assessment questionnaire that will later be compared to the second survey pertaining to compliance.

This work will discuss the current conditions of affordable housing in San Luis Obispo. It will compare these findings to literature research, case studies that address best practices for designing affordable housing, as well as provide an overview through an analysis of administered surveys, which are designed to evaluate the quality, design and location of the current affordable housing stock. The paper will conclude with extrapolations of the future prognosis for the creation of affordable housing in San Luis Obispo. It also describes toolkits that can and should be implemented to help the growth and quality of affordable housing in the City. 


\section{LITERATURE REVIEW}

\subsection{HISTORY OF AFFORDABLE HOUSING IN THE U.S}

The Housing Act of 1937 seemed to be a benchmark for the beginning of affordable housing in the U.S. However, before the Housing Act was adopted the correlation between housing and income existed and was seen as an issue the U.S. had to face. According to Martens (2009) "housing was not a policy issue in our nation until the mid to late 1800's. Prior to that, before the industrialization of America, most Americans worked where they lived. By the 1850's, when massive job creation occurred in the cities and when rural Americans and immigrants flooded the urban centers in great numbers, there was a critical housing shortage" (pg. 2). With the housing shortage occurring, the only response was to redevelop or convert the single-family homes into apartment style homes and fit in as many people as possible. This caused deplorable conditions to the homes and affected the health and safety of those living in these cramped quarters. These were not decent living condition.

In 1879, the New York Housing Act was established. This was the first tenement house code, which required "tenements to provide minimal air and 
light to the interior rooms of the building. It resulted in what came to be known as "dumbbell" buildings, because of the two narrow interior air shafts that were added to meet the code requirements. Significant changes to the standards for ventilation, fireproofing, and adequate sanitary facilities, however, did not take place until the new century with the enactment of the Tenement House Act of 1901, which served directly or indirectly, as a chief working model for most of the tenement house legislation of America since that date" ( Mallach, 2009, pg. 30).

Affordability for the tenement dwellers was a factor, especially since many were taking in boarders or doubling up with other families to afford the rent. As it is still true today, the balance between income and rent is a large problem associated with affordability.

\subsection{POST OCCUPANCY EVALUATIONS FOR AFFORDABLE HOUSING}

The significance of a home as it differs from a house is described by Mallach as follows:

A home has always meant far more than shelter from elements or a convenient place to carry out the necessities of daily life. Individually, they provide the setting within which each family frames its domestic existence; collectively, they define their block, their neighborhood, and their community. How well they perform those tasks greatly affects the stability and health of the family and community (Mallach, 2009, pg. $54)$. 
In many cities, new housing projects are built and never evaluated after the new occupant has moved in. Often times, the developers and designers don't follow-up with the user(s) of the space to find out what qualities of the building work well and which cause projects to fail. In best practice cases, POE's or Post-Occupancy Evaluations are done 6 to 9 months after being occupied.

In the 1940's public-affordable housing was thought as being "purposely cheap and austere. Apartments contained no storage space for such large articles as bicycles or suitcases, as these purchases represents a more comfortable life than the tenant was supposed to enjoy" (Mallach, 2009, pg. 55). "Many low income housing projects developed in the past, have been showing inadequacy of the designs to reality and a high level of dissatisfaction of its users" (Ralid, pg. 1). The demand for affordable housing is rising, especially with the decline in the economy and loss of jobs. However, the design and quality of construction for affordable housing has not superseded the demand for affordable housing. Although affordable housing has the word "affordable" in it, it doesn't mean the materials should be cheap or the thought that goes into the design be any different. Often times new affordable housing is being constructed in a budgetary sense by cutting construction cost, which in turn diminishes the quality of the materials as well as the construction. By conducting POE's, the architect or designer can focus on what needs are and are not being met by the construction of new affordable housing units. 
Although residential POE's are desirable, they often are not done. POE's conducted in office buildings or buildings that are LEED (Leadership in Energy and Environmental Design) rated are more common. POE's for LEED rated buildings often include surveys of the building occupants, observations and/or interviews with building users, performance in terms of energy and/or water consumption and physical measurements such as; temperature, humidity, acoustical, lighting, and day lighting. When using the LEED for NC (New Construction) rating system, facility managers can receive one point for doing POE surveys that assess thermal comfort. In order to receive the one point the survey must be performed six to 18 months after the facility has been occupied. Not only do the developers receive an extra point in the LEED rating system, they often seek to use the LEED rated building as best practice case studies for future projects. Many new developments are not considering conducting POE's, but many are choosing to design with LEED standards. Since POE's are an integral part of the LEED rating system and will increase the points a building will receive, POE's are becoming more and more popular and part of common practices. Not only will POE's help in the LEED rating of a building it also brings a financial benefit to the developer, which may include tax credits, tax breaks, density bonuses, reduced fees, priority or expedited permitting, grants and low-interest loans. The future of Post Occupancy Evaluations needs to transition its focus onto residential, especially to affordable housing. 
POE's "focus on a building's occupants and their needs, provides insight into the consequences of past design decisions and forms a sound basis for creating better buildings in the future" (Preiser, Rabinowitz \& White, 1988). Not only do the POE's help in future developments for affordable housing, it allows for feedback, troubleshooting and "documentation for successes and failures in building performance" (Preiser, et, al., 1988). Benefits of POE's for affordable housing, experience short term or long term benefits. Short term benefits can be as simple as changing the attitude of the occupants by education, whereas the long term benefits can include improved measurement of the buildings quality assurance.

POE is one of the methodologies to evaluate the build environment performance. It differs from other current methodologies because it considers not only the technical aspects (project and construction data) but also considers in a very important way aspects related to use, operation and maintenance of the build environment (Ralid, pg.2 )

There are many methods to conducting POE's, one of which is a survey or questionnaire. Also on-site observation visits that consist of photographing and documenting what is observed in the outside and inside space are used. A large issue surrounding affordable housing is the negative perception that affordable housing has to look affordable. The next section discusses this design stigma surrounding affordable housing. 


\subsection{DESIGN STIGMA SURROUNDING AFFORDABLE HOUSING}

Many negative connotations surround the word affordable housing. Often times when an affordable housing project is being newly constructed within a community and/or neighborhood, it is perceived negatively. Many people associate affordable housing with crime, increase traffic, decrease in property values, and discriminate; assuming a particular social class will be occupying the affordable units. However, studies have found these assumptions to be incorrect. Although there are many negative assumptions that are connected with affordable housing, design stigma seems to be a much larger factor.

One compliant about affordable housing is that the design and construction generally don't fit into the surrounding and nearby neighborhoods. The weakness encompassing affordable housing design is that it takes on an "institutional approach, which is to use indestructible materials, whether concrete blocks or metal, which means the interiors tend to be prison-like. It sends a message to the residents that they can't be trusted with their homes" (Ellwood, 2010). This raises the question: does the design of affordable housing have to look or appear affordable? The answer is no, the design and construction of an affordable housing project does not need to look affordable. There are examples of effective, well designed affordable housing projects which can illustrate a new and innovative approach to 
the construction of affordable housing and overshadow the existing design stigma.

\subsubsection{Why Design Matters}

"While design matters for all buildings, whether for rich or poor, residential or commercial, it has an added significance when it comes to affordable housing. Affordable housing, by its nature, is housing for people who have fewer resources and fewer options outside the home than more affluent families. As such its residents are likely to become more dependent on their immediate environment, both the individual dwelling unit and the building or complex of which it is a part, than are the residents of more expensive housing, who are more mobile and more able to pay for entertainment and travel outside the community" (Mallach, 2009, p. 54).

Another reason why design matters is to break the stigma surrounding affordable housing. This stigma has lingered with affordable housing projects throughout the history of affordable housing. " Although the first examples of American affordable housing were often well designed with appropriate facilities-like 1931 Carl Mackley Houses in Philadelphia, which included a nursery, a library, and a swimming pool-after the initial reformist zeal of the New Deal wore off, affordable housing, in architect Sam Davis's words, became "mean-spirited, the dwellings Spartan" (Mallach, 2009, pg. 55). By the 1940's the only reason to build affordable housing was for the purpose of public housing, which created cheap and austere housing. 
Some features that affect design are "demographic, in terms of such characteristics as age distribution, number of children, or the likely proportion of single-parent households; and economic, in terms of the incomes, jobs, and assets of the households" (Mallach, 2009, pg.59). Also cultural features should be taken into consideration when designing affordable housing.

In order to shift the stigma of design for affordable housing from this conceptualized idea of a sparse, cheap, ugly building to a lively, innovative and architecturally pleasing building, designers and planners need to come up with new ways to design affordable housing and come up with new ways to integrate the housing with the surrounding environments.

Affordable housing does no need to appear affordable. Planners and Architects can and are designing affordable units that fit in with both the fabric of the neighborhood and the surrounding architecture. "Compatibility between new and existing housing can often be eased by straightforward design guidelines that address such features as maintaining a consistent setback line or a consistent pattern of variation in setbacks, and replicating key design features, such as porches, stoops or gables" (Mallach, 2009, pg. 72). With proper design guidelines set forth by a city, the affordable housing projects can blend in with the surrounding housing development including the market rate housing. 
A new team called the Affordable Housing Design Leadership Institute brings together architects, planners, community developers and non-profit developers in a 2 day brainstorming session, which focuses on innovative and best practices in community design surrounding affordable housing. They explore possibilities from seven different projects that are in the schematic process and are faced with affordable housing design challenges to overcome. Many positive results have accompanied this process.

How can cities still be sure the design of the affordable housing won't look like every other drab affordable housing project? Along with separate design guidelines for affordable housing, and similar tactics generated by the Affordable Housing Design Leadership Institute, cities can create design toolkits to help improve upon the current design practices. Since, more and more affordable projects are being praised for their design; cities can take pieces from each of these projects to build upon an affordable housing toolkit. This can raise development leaders' capacity to produce more livable and sustainable housing for low and moderate-income people living in the U.S. Collaboration with communities and design professionals can help solve the issues surrounding the design of affordable housing. Exemplary case studies will be discussed in Chapter 3: Best Practices. 


\section{BEST PRACTICES}

\subsection{DESIGN CASE STUDIES}

The case studies presented are exemplary constructed housing projects. Three of the case studies discussed have earned Housing and Urban Development (HUD) awards in 2010 for the very prestigious Housing and Community Secretary Design Award. These awards are for excellence in residential housing design by HUD in conjunction with the American Institute of Architects (AIA). Shaun Donovan HUD's Secretary spoke of these projects as "developments that challenge the old ideas about how affordable housing can fit into the fabric of their surrounding communities, helping to build vibrant, sustainable communities starts at the drawing board and each of these developments proves that thoughtful design can create a lasting imprint on our neighborhoods" (HUD, 2010). The senior exemplary case study demonstrates how a senior affordable living center can be designed using green technology. The case studies to be discussed in this chapter have been selected because they demonstrate innovative and thoughtful design. They were chosen based on being award- 
winning designs for single-family, multi-family, live/work and senior residences.

Along with the case studies a cost analysis is made in order to compare subsidies and construction cost between an innovative and award winning design for an affordable housing project and a more typically seen design of a multi-family affordable housing project. The case studies chosen will demonstrate exemplary examples from California, Texas and Arizona. The four case studies demonstrating state-of-the-art design include Congo Street Initiative, located in Dallas Texas which is a single-family affordable housing unit, Yuma Senior Terraces, located in Yuma, Arizona, an affordable senior living center, The Arbor Lofts, located in Lancaster, California, a live/work affordable housing unit and Paseo Senter at Coyote Creek, located in San Jose, California which is a multi-family affordable unit. Also a brief discussion comparing the Paseo Senter; a new and innovative design to Dove Canyon Apartments; a more commonly seen typical design for affordable housing will be compared in terms of construction costs. This will help in analyzing if affordable housing designs similar to that of Paseo Senter are financially feasible and could possibly be the future of and illustrate the right track for affordable housing. 


\subsubsection{Single-Family Case Study}

Figure 3 Congo Street projects' before and after photos.
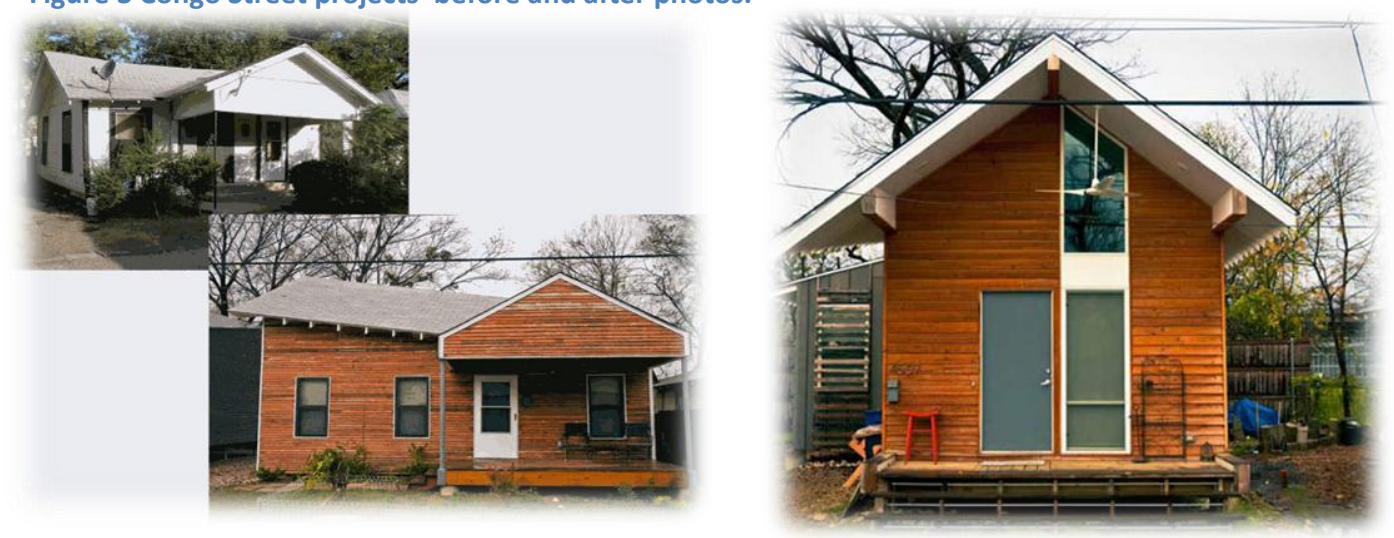

The first case study is a project located in Dallas, Texas and was initiated by Architect, Brent Brown. The Congo Street Initiative of Dallas redesigned and reconstructed the look of this narrow street, which houses 17 single family and duplex houses. Most of these buildings were built prior to 1910 . This project demonstrates that not all affordable housing needs to be new construction. With some innovative and inexpensive ideas, they were able to transform these outdated affordable homes to appear as anything but affordable. Most often people assume affordable housing is only high density, multifamily housing, but in this case these were single-family residences. In order to keep redevelopment cost down the homes were rebuilt using salvaged materials from their existing home. The concept behind this project was the "creation of a temporary home, or "holding house," to house the family whose home was currently under renovation" (AIA, 2010). 
The challenge was how to redevelop without relying upon relocation, even temporarily, or incurring steep financial burden" (AIA, 2010). The solution of this project was to keep residents on-site and connected to the construction of their new home. The residents were involved with both the design and construction process. This model of a holding house "challenges the current scope of urban revitalization, which prior to this have taken the approach of slum clearance or urban infill, and gives new value to disadvantaged communities by bringing innovative ideas to their front porch" (AIA, 2010).

\subsubsection{Senior Center Case Study}
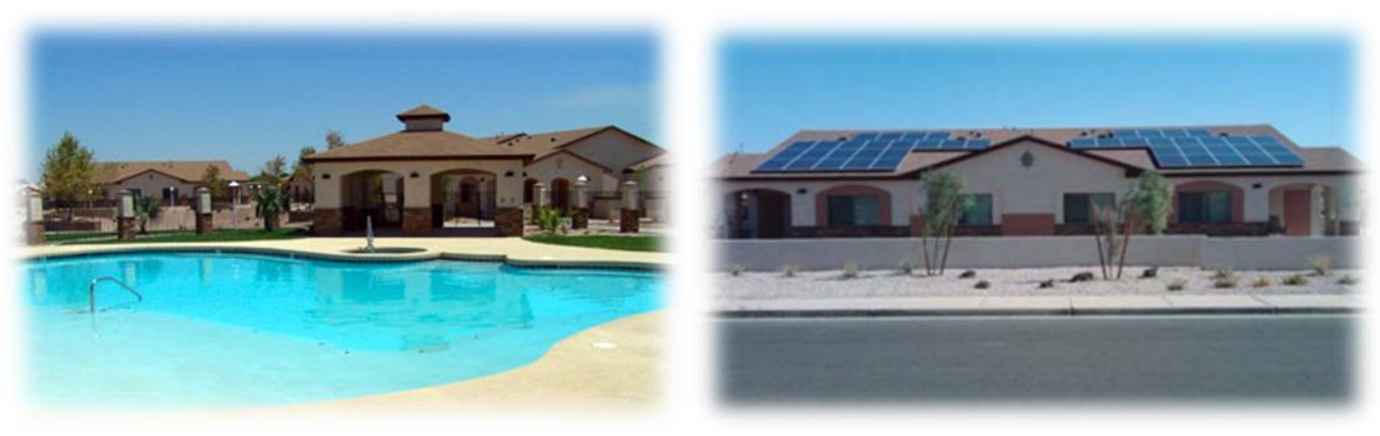

Figure 4 Large central pool and display of solar panels.

The second case study is Yuma Senior Terraces located in Yuma, Arizona. The Yuma Senior Terraces offers 60 affordable units to $65+$ seniors with a more resort-style community consisting of scheduled activities, formal dining rooms, country kitchens, dog park and pool. The main highlight of this senior living center is how it was constructed. It was constructed using green technology called Insulated Concrete Forms (ICF). This method reduces 
waste to the landfill, reduces energy costs by 50-60 percent, the material is inhospitable to pests and reduces insurance and maintenance cost. The ICF device consists of layers of foam insulation with an opened center cavity for concrete. Each piece interlocks with the next to form a dry-stacked modular unit. Then concrete is poured into the center cavity to form a structural element to the wall.

The project also has solar tubes in each unit to provide natural daylight and reduce electricity costs as well as solar panels to take advantage of the areas 328 days of sunshine per year. Along with the green technology the interior material used within the units are made of sustainable materials. The cabinets are made from composite wood that contains no urea-formaldehyde resins, the carpeting is part of the Carpet and Rug Institute Green Label Plus Program, and each unit is equipped with energy star rated appliances. This case study displays how a senior center can use green technology to not only lower greenhouse gas emissions, but provide affordable housing to senior citizens in a contemporary and architecturally attractive manner plus lower maintenance. 

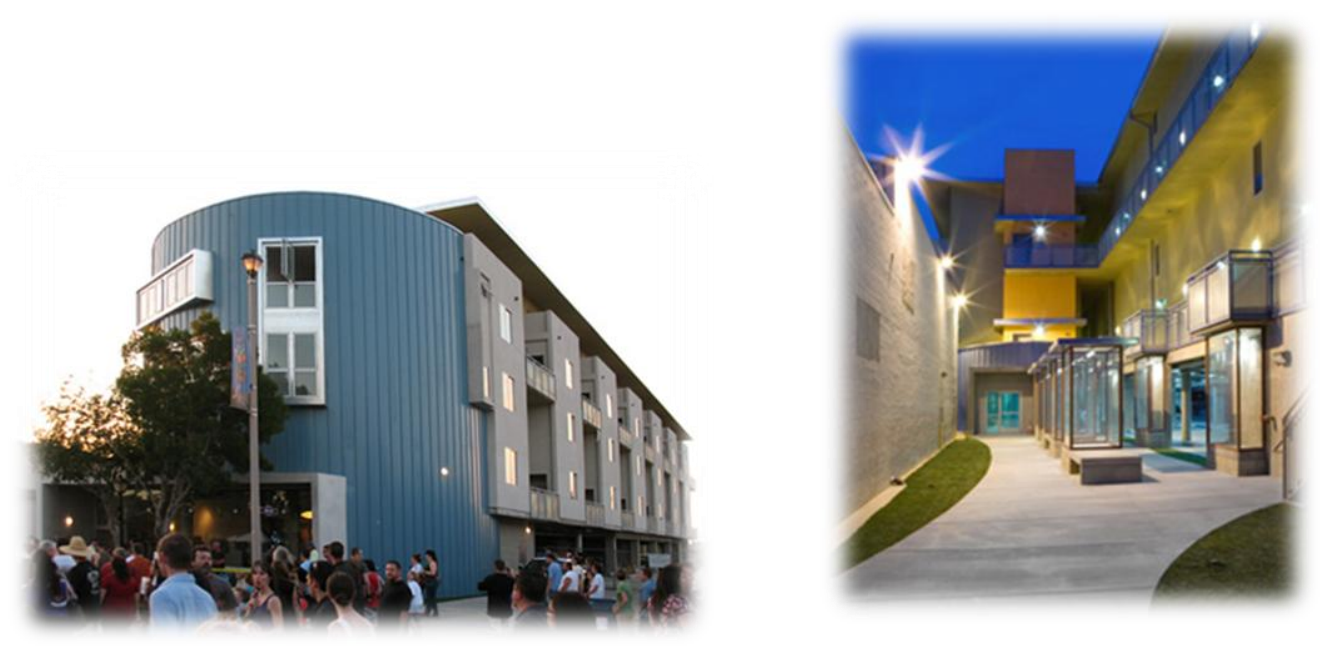

Figure 5 Arbor Lofts street view (left) and interior courtyard (right)

The third case study is by PSL Architects who completed the Arbor Lofts in 2009. Arbor Lofts are located in Lancaster, CA and incorporates a 21 unit affordable housing project at 29 du/acre. This infill project features a useful live/work space especially designed for local artists. These units are for those tenants who earn at least $50 \%$ of their income by making art and are below $60 \%$ of the area median income. The firm consulted with local artists to find out what amenities they would like to see in the live/work spaces. The feedback resulted in a 2-story building, with "open-plan units featuring concrete floors, exhaust vents to expel chemicals, and 220 -volt outlets to accommodate a kiln or welding equipment. Included in the design is a storefront community art gallery and a public sculpture garden. The design provides an iconic and richly articulated building to re-activate and anchor the city center" (PSL Architects, 2009). 
Although this affordable project is directed at artists, it illustrates the way design is made to fit the user and introduces innovative design methods in new affordable housing developments. The functionality of the building is directed towards artist to accommodate their materials and mediums, i.e. acrylic paint, spray paint, watercolors or resin which give off hazardous fumes. A live/work unit allows the user to work at home, which mitigates both gas and pollutants as well as the cost to rent a workspace on top of rent. This case study represents a new wave of future designs for affordable housing which allows families to earn a living from their homes.

\subsubsection{Multi-Family Case Study}
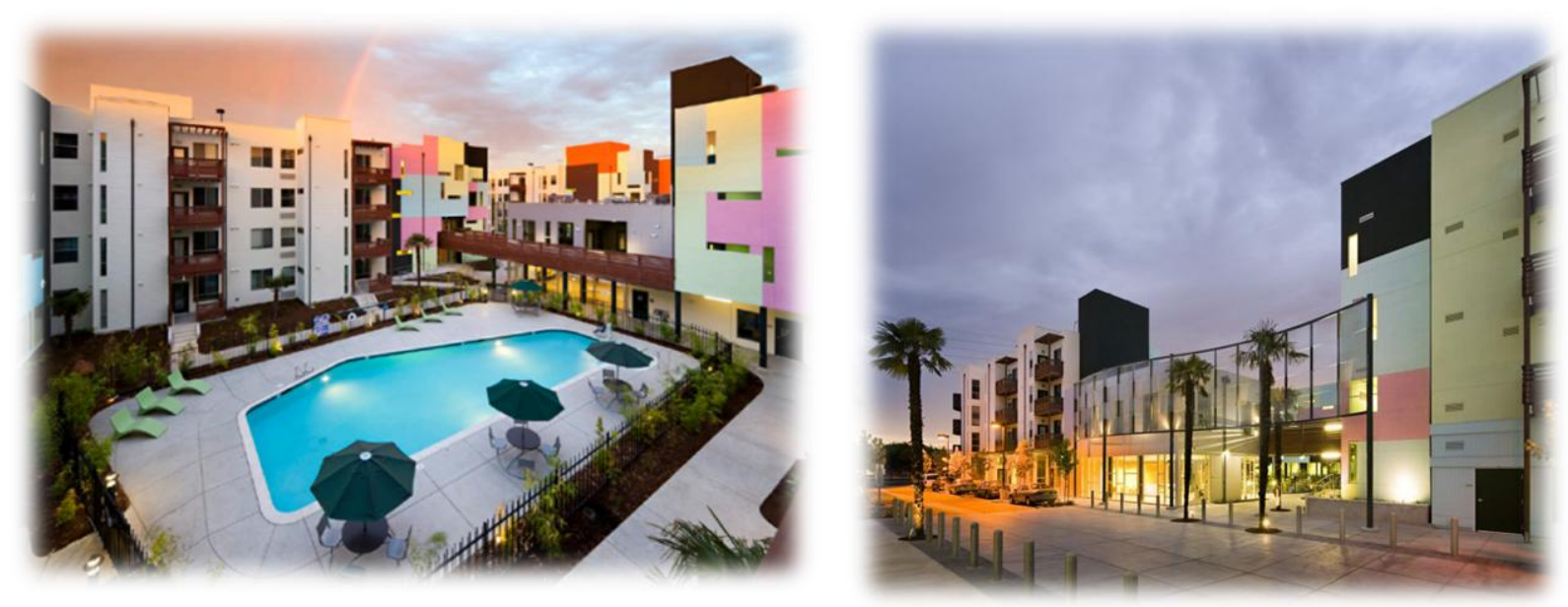

Figure 6 Paseo Senter inner courtyard (left) and exterior façade (right).

The fourth case study, Paseo Senter at Coyote Creek in San Jose, CA is designed by the architecture firm David Baker and Partners. This development is situated on 4.3 acres, which has not only created 218 affordable rental units consisting of 1 to 3 bedrooms, it has also included "pedestrian friendly uses, such as residential entry 
stoops, a community room, a library, social support spaces, and childcare and kin caregiver centers" (David Baker, 2008). The affordability level was $30 \%$ of the units were for extremely low households and $70 \%$ were targeted for very low households. The residential units stand at three-stories high and sit above retail-style service spaces.

This project has also received other awards for its state-of-the-art design, which included 2009 residential architect design merit and 2008 Silicon Valley business journal structures award: affordable housing development of the year. The projects main features are to "calm traffic and empower pedestrian use" (Baker, 2008). It has created a "place in a previously disconnected, disused section of the city and has responded to both the needs and constraints of affordable housing" (HUD, 2010).

The Paseo Senter not only surpasses the stigma of affordable housing appearing outdated, boring and bleak, it also has focused on the needs of the community. It has offered multiple options as far as bedrooms, for single residents to families, which creates a diverse housing community. The architecture and design are those seen in high-end, high density residential. If more affordable housing projects looked and functioned like this, less people would disapprove of affordable housing. Actually, most would not even know this project was affordable. However, how does this project compare both financially and aesthetically to another affordable project that is smaller in scale and a typical and/or simpler design? Can this type of well-designed project which is aesthetically pleasing also be affordable? 
As far as the cost and construction of the affordable housing project, the developers were Charities Housing Development Corporation and CORE. The construction of the project was built in phases, with the construction beginning in March 2006. Phase II opened first in May 2008 and Phase I opened in August 2008. Many times when affordable housing projects are built in phases, it is done more so on standards which are set by the lending bank. The bank may want a certain portion of the first phase to be completed and/or occupied before lending the remaining money.

Like most affordable housing projects, subsidies and funding from RDA's have been used to help offset the development cost. In this case, the project received funding from several entities: Centerline Capital Group, U.S Bank, City of San Jose, HCD, Federal Home Loan Bank-AHP, HUD McKinney, Housing Trust Fund of Santa Clara County, County of Santa Clara and Opportunity Fund. The original estimated project costs were estimated at $\$ 54$ million. Phase II, which provided 101 apartment homes, totaled $\$ 36,912,666$ with $\$ 5,939,550$ L\&M (Redevelopment's Low and Moderate) housing funding. In this project the funding from redevelopment agencies played a significant role in making this project possible, however with the loss of RDA's the possibility for more projects like this one may be scarce. 


\subsubsection{Traditional Approach to Affordable Housing Design-Senior Center}
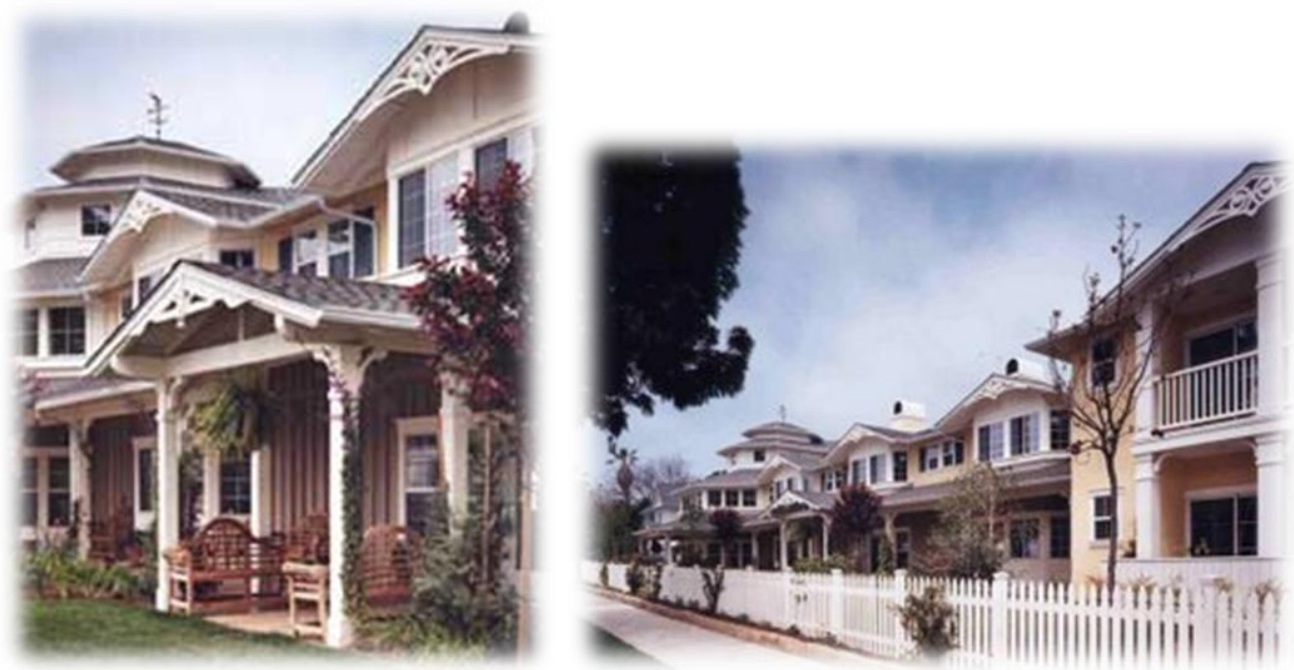

Figure 7 Entrance to multiple units (left) and street view (right).

The Garden Court at De La Vina in Santa Barbara, California is a more typical and more commonly practiced design for a senior living center. "The Garden Court was built in response to a desperate need for very low income housing for the frail elderly in Santa Barbara, California.

The Carrillo hotel demolition in 1994 was due to the state mandate that directed facilities to rebuild or renovate to meet certain earthquake standards. The property owners chose to demolish the building rather than having it retrofitted which cause the displacement of 120 seniors and exacerbated the need for affordable senior housing.

A public-private partnership consisting of resident and senior advocate groups were involved in the design, planning, and funding of Garden Court. The high density of Garden Court adds vitality to the downtown area, and its close proximity to services (1-2 blocks) such as, grocery, pharmacy, senior 
recreation center, transit center, downtown shopping makes it an ideal home for many seniors. Built on an infill site that contained derelict apartments on underutilized land, the Victorian styling and massing of Garden Court echoes the predominantly residential neighborhood in which it was built" (Design Matters).

This project is an illustrious example of affordable housing placement and/or location and has shown the significance placed on the surrounding amenities. It demonstrates why in an assessment survey, questions pertaining to location and access need to be asked. This project serves as an excellent example of sustainable affordable housing that responds to seniors need to be close to daily-use services and retail.

The next two case studies, demonstrate a more traditional and typical approach to affordable housing for multi-family situations and senior living. The architecture and design displays a more conservative side to affordable housing.

\subsubsection{Traditional Approach to Affordable Housing Design-Multi-Family}
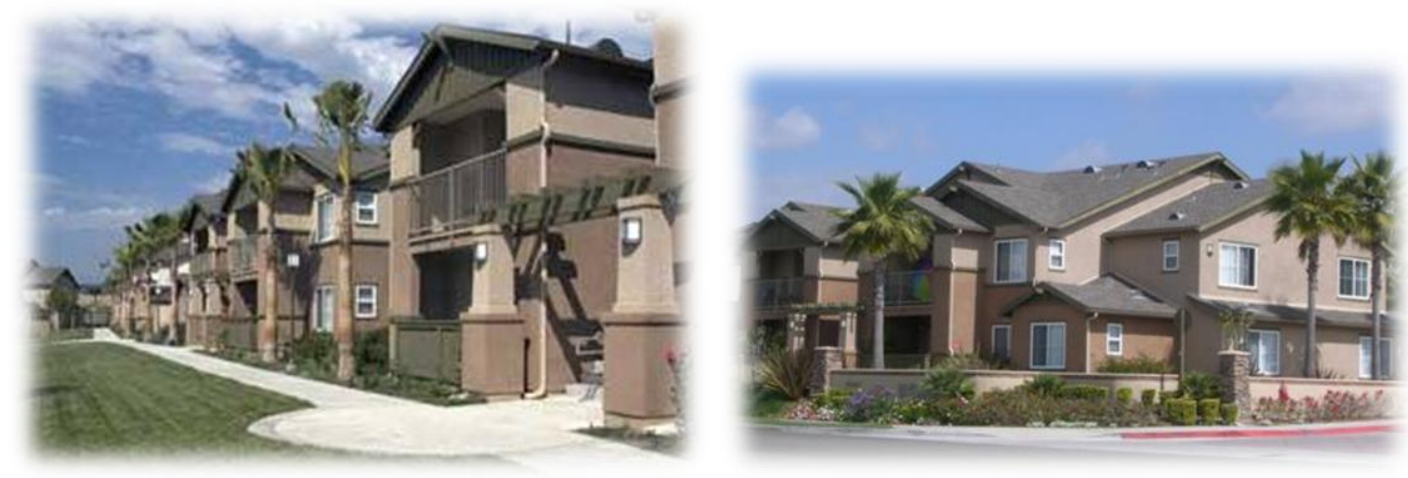

Figure 8 Exterior photos of Dove Canyon Apartments. 
Dove Canyon Apartments was designed by KTGY Group and is located in San Diego, CA. The designed was inspired by the Craftsman style. This style and similar styles are typically used in newer affordable housing complexes. The development offers a swimming pool, a large multipurpose community center and a computer-learning center. It also offers many outdoor activities, such as basketball courts, large picnic areas with BBQ's and a playground for the kids. It provides 120 units all of which are affordable. Although this design does not appear affordable, it also is not very innovative. The project value is much less than that of the Paseo Senter. The project totaled $\$ 15,500,000$, roughly $\$ 38$ million less than Paseo Senter. Although Dove Canyon has fewer units it breaks down to approximately $\$ 100,000$ less per unit than that of Paseo Senter. Many factors can determine the cost of a project, such as land costs and the median income in the area. There were financial partners and subsides involved which consisted of; Union Bank of California, Wells Fargo Bank, CalHFA, and County of San Diego Department of Housing and Community Development. It appears after the financial comparison that innovative design tends to be more expensive.

As seen in the case studies above, affordable housing does not need to appear affordable. Planners and Architects can design affordable units that fit in with both the fabric of the neighborhood and the surrounding architecture. "Compatibility between new and existing housing can often be eased by straightforward design guidelines that address such features as 
maintaining a consistent setback line or a consistent pattern of variation in setbacks, and replicating key design features, such as porches, stoops or gables" (Mallach, 2009, pg. 72). With proper design guidelines set forth by a city, the affordable housing projects can blend in with the surrounding housing development including the market rate housing. 


\section{MONITORING PROGRAMS}

\subsection{MONITORING PROGRAM CASE STUDIES}

Several cities already have adopted monitoring programs and procedures for their inclusionary housing units. These monitoring program case studies will serve as precedents for developing a monitoring program for the City of San Luis Obispo.

Each of the case studies will have segments of their monitoring programs that the City of San Luis Obispo can use in their development. The City of San Francisco's monitoring program serves as a great example for laying out a procedure manual that including all the basics of purchasing or renting an affordable unit on top of the monitoring procedures and enforcement for the units if deemed out of compliance. Whereas, the City of Pleasanton and the County of Santa Barbara have an example of a great survey and outlines specific restrictions the tenants must follow. The City of Santa Cruz has designed a simple monitoring process with an aggressive approach to resolving non-compliant units. 


\subsubsection{City of San Francisco}

The manual was adopted in 2007 by the City of San Francisco, CA. The manual describes the steps owners and renters must go through to qualify to purchase or rent an affordable unit. It also describes what shall be done in the efforts to monitor the units and execute the certification, which is required and governed annually by the San Francisco Mayor's Office of Housing $(\mathrm{MOH})$.

According to the planning code section 315 , it "requires that the $\mathrm{MOH}$ and the San Francisco Planning Department publish a Procedures Manual containing procedures for monitoring and enforcement of the policies and procedures for implementation of the program" (SF Inclusionary Affordable Housing Program Monitoring and Procedure Manual, 2007,pg. 2). The monitoring procedures for Below Market Rate (BMR) Ownership units require copies and evidence of occupancy certification on an annual basis. The owners of a BMR unit are required to submit an annual monitoring and enforcement report on a form provided by $\mathrm{MOH}$ and submitted on a date and at a location determined by $\mathrm{MOH}$. The report may involve information "regarding occupancy status, changes in title, and any other information $\mathrm{MOH}$ may reasonable require to monitor compliance with the BMR units specific planning approvals or other use restrictions" (City/County of San Francisco, 2007, pg. 30) 


\subsubsection{City of Pleasanton}

The City of Pleasanton was contacted to identify if they have implemented a monitoring program for their affordable units. Some background information was provided as well as a sample survey that the City sends out annually to their residents. The survey yields both demographic data and reminds owners of the key restrictions that were addressed in their affordable housing contract. It also reveals the steps the City took to implement the program (Scott Erikson, City of Pleasanton).

It took the City of Pleasanton several years to create a monitoring system for owner occupied units that included several components, including a periodic survey tool and a database to track and monitor data on units, owners and loan activity. The owners must submit annual reports and otherwise make their records available for inspection by the City at any time. The Housing Specialist also tries to make it out once a year to inspect the units if a property is absent of an on-site manager.

\subsubsection{Santa Barbara County Monitoring Program}

The County of Santa Barbara has a monitoring program in place for their ownership units. The Affordable Housing Ownership (AHO) restrictions include both a deed restriction, which places limitations on the unit for a period of time, i.e $10,20,30$, or 45 years 45 and a monitoring program. All the homes are subject to being monitored. Each year owners are required to complete and submit annual surveys or certifications regarding 
occupancy, financing, and compliance. The department reserves the right to conduct arbitrary site visits to their homes. The following is the information that is to be verified and restrictions that the owners are subject to.

- Owner agrees to occupy the property as his/her principal place of residence and live in the unit a minimum of 10 months out of a 12 month period. Owner may not rent out the property.

- The owner agrees to assist and cooperate with County sponsored annual surveys/certification regarding occupancy, financing, and use of the affordable unit. Each year, the owner is required to submit an annual certification (usually due March 1st of every year). This is the owner's opportunity to declare that they have complied with all the requirements of the restrictive covenant that was recorded on the property at the time of purchase.

- The restrictive covenant remains in effect until the unit's assigned expiration date, as outlined in the covenant.

- The terms of all financing at the time of sale, or any other time (i.e. refinancing or securing any additional financing) must be approved by the County of Santa Barbara in writing prior to executing.

- The County has the first Option to Purchase the property when the unit is offered for sale, goes into foreclosure, or falls into default.

- The owner may sell the property at any time for the restricted affordable price set by the County of Santa Barbara until the unit's 
assigned expiration date. The Owner must first notify the County of their intent to sell.

- An owner must sell their unit to another household that qualifies under the County's program until the unit's assigned expiration date.

- All individuals living in the household agree that the County may audit the household for re-evaluation purposes if it is suspected that false or misleading information was ever provided at any time prior to purchasing the unit or while owning the unit.

- Placing a unit into a trust or living trust is strictly prohibited.

- An affordable unit may be passed on to an heir, successor, executor, etc. However, the Restrictions will remain enforceable on the property. An heir, successor, etc. may keep the property only if they qualify for the program and will have to follow the same restrictions in the affordability covenants. If not, he/she/they must sell the property to a qualified household. (County of Santa Barbara HCD, 2012).

If any owner occupied unit is found out of compliance with the monitoring program, the County will take an aggressive approach and the County will enforce and remedy any breach.

\subsubsection{City of Santa Cruz}

The City of Santa Cruz annually monitors owner-occupied and rental inclusionary housing. Compliance with the monitoring requirement is established in the recorded affordability agreements. The monitoring process is: 
1. Staff sends a request for an Annual Compliance Report ("ACR") to owner-occupants and owners of rental units.

2. Staff reviews the ACR for compliance with the recorded affordability agreement.

3. Staff sends follow-up requests for the ACR if the ACR was never received.

4. Staff sends follow-up letters requiring compliance or correction.

5. Staff sends clearance letters.

"The City of Santa Cruz takes an aggressive approach to ensure compliance. Any out of compliance units receive demand letters to comply and are subject to administrative civil penalties (fines) under our municipal code. Court action is available as a last resort" (Email received from Norm Daly, City of Santa Cruz).

The monitoring program case studies highlighted here can serve as a starting point for the Monitoring Program Procedure Manual for the City of San Luis Obispo, which is Appendix A of this paper and a deliverable to the City. The simple and clear approach of a survey similar to that of the City of Pleasanton appears to serve as the best example to follow. This survey combined with a simple procedures manual with steps to follow in the future implementation of the program provide a good model for the City of San Luis Obispo. 


\section{ASSESSMENT OF THE CURRENT AFFORDABLE HOUSING STOCK}

The current affordable housing stock in the City of San Luis Obispo consists of roughly 230 affordable units. In order to obtain a valid assessment of the current quality, design and access to amenities, a survey was administered to residents of all affordable housing units in the City of San Luis Obispo.

\subsection{PROCEDURE + DESIGN OF SURVEY}

In the development of the survey, research was done to create questions pertaining to what creates good design as defined by planners and architects. The research involved, gathering information from sources and references that discussed design standards from the perspective of architects and planners. One source "discusses steps taken to design a residential home and what aspects an architect focuses on during the preliminary design efforts" (Malone, 2010). Another resource by APA (American Planning Association) discusses key elements that go into designing affordable housing based on planning for and preserving the affordable housing stock" (Mallach,2009). 
When it comes to good design from a planners approach, they often look into the larger picture of how housing fits into the surrounding environments. Whereas, the architects approach looks at more the aesthetics of the building, the built quality and indoor air quality. The architects approach focuses more on the building in itself rather than how it fits into the surrounding spaces. Within the survey, many questions encompass the location and use of a particular affordable unit in reference to local amenities; such as grocery stores, schools, bus stops, shopping, bike paths, parks, and laundry facilities. The evaluation of the proximity of the units to the surrounding services, offers an insight into walkability to amenities and support services. It offers an understanding to the question, Are affordable units being placed in the best possible location? Questions like these are often times asked by a planner, who need to look at overall city functions. In contrast an architect would ask questions relating to use of spaces within a home, perception of air quality and if energy saving appliance are being used to cut energy use and costs. Although a planner and an architect may have different ideas into what make good design for affordable units, the collaboration of both professions serves to achieve amazing results that meet the needs of residents both within and outside their homes which will be discussed in the following sections. The integration of the two types of questions were integrated within the surveys that were sent out in San Luis Obispo. They hopefully prove to be the best approach to residential POE's in San Luis Obispo, especially with respect to the affordable units. The 
background and layout of the survey incorporates questions based on the following information obtained from the research on key elements in design from an Architect's perspectives as well as a Planners perspective. Further information about the context of the survey will be discussed later on in this chapter.

\subsection{ARCHITECTS KEY ELEMENTS IN DESIGN}

In researching residential design from an architect's point of view a few key elements were discussed. Some key elements included: building size (sqft.), parking associated with building (i.e. garage, carport) as well as number of parking spaces, clear articulated circulation inside the building, the layout of spaces and the energy efficiency of the home. Architects don't want to design affordable housing that screams affordable or "cheap".

There has been a philosophy that said "anything well-designed will be too appealing to eligible tenants, thus discouraging them from ever leaving. So affordable housing should not only be cheap, it should look cheap. As a result, much affordable housing is more punitive than homey, by design. Fortunately, there are a number of architects and developers bucking this long-running and convoluted mindset. Architects, builders and developers have succeeded in designing affordable housing free from stigma and institutional homogeneity, creating projects that express hope and possibility." (Arieff, 2011). Some examples are as follows: 
1. Sierra Bonita Affordable Housing, West Hollywood, California (2010)

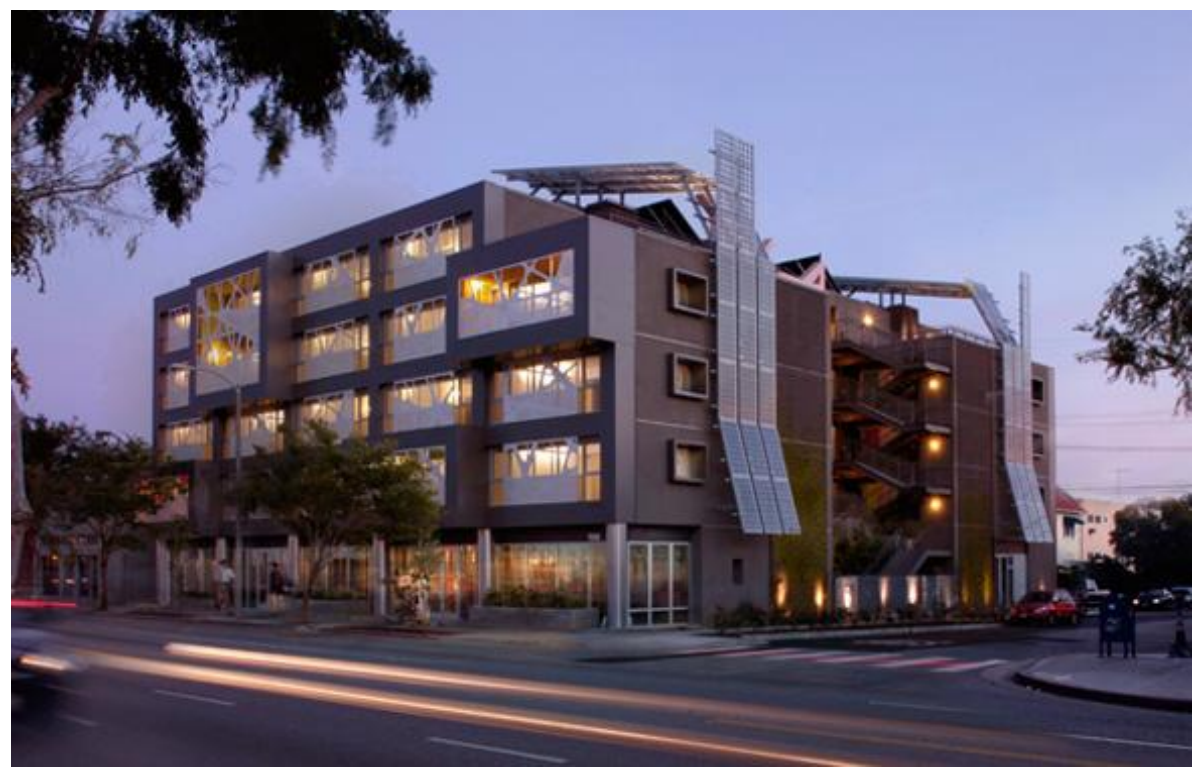

Figure 9 Street View

“The very antithesis of institutional is Architect Patrick Tighe's Sierra

Bonita building. Rivaling any luxury condo project but costing just $\$ 14$ million for 42-units, the energy-efficient, mixed-use building has a courtyard garden, integrated photovoltaic panels that double as shade canopies for the building's terraces, and a gorgeous laser-cut aluminum screen façade. The 50,000 square-foot structure serves people living with disabilities and houses non-profits such as AIDS Project Los Angeles on its ground floor." (Arieff, 2011). Again the cost of the land and median income in the area are determining factors for the overall costs to the project. Also the availability of vacant land or land designated for residential use is another determining factor. 
1. Via Verde, the Bronx, New York (2011)

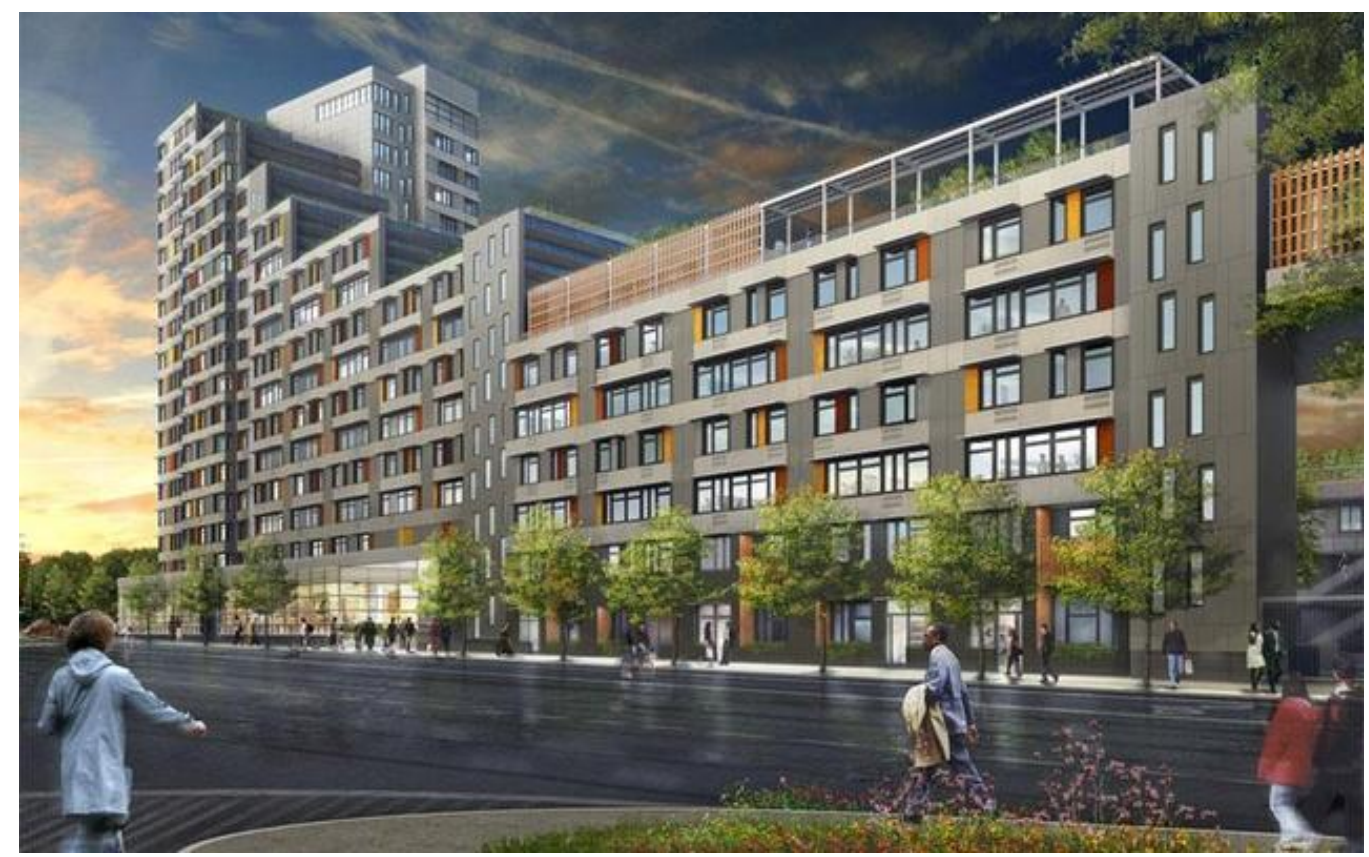

Figure 10 Rendered Exterior Street View

"Of this recently completed subsidized housing project in the Bronx, New York Times architecture critic Michael Kimmelman wrote, "Like all good architecture, it is handsome. Unlike too much, it goes out of its way to be healthy." In stark contrast to the proliferation of "green luxury" condos popping up all over New York, here sustainability isn't used as a marketing tool but rather as a way to create what residents wanted: a healthy place to live. Developed by Phipps Houses and Jonathan Rose Companies with Dattner Architects and Grimshaw to exceed LEED Gold standards, the project includes green roofs, solar shading, rainwater harvesting, has room for growing fruits and vegetables, and provides open space, bike storage, and a fitness center for residents." (Arieff, 2011). 
The two examples of good design by an architect discuss healthy living and or green design. Implications for the survey design, which will be discussed in greater detail in Section 5.4 and is seen in Appendix B, question 12 asks the participant to evaluate the number of hours spent in each room during an average work week. This question can tell the architect which spaces are being used the most frequently and which spaces in the home are the most essential to the user, thus relating to question 13 , which evaluates the air quality, ventilation, natural lighting and heating and cooling for the spaces discussed in question 12. This question relates back to the above example about creating a healthy place to live for the residents of affordable housing.

Question 6 in the survey (Appendix B) refers to the type of home the participant is living in. Many assume all affordable housing units are designed as multi-family units, however there are some detached single family residences located in SLO that are deemed affordable housing. Questions 7 and 8 deal with aesthetics of the building and how parking relates to the design. Often times, affordable housing units don't have garaged parking, as seen in market rate housing. Findings of these questions will be discussed in more detail in Section 5.6.

\subsection{PLANNERS KEY ELEMENTS IN DESIGN}

As mentioned earlier, a planner looks into the larger picture of design and an overall effect to the surrounding areas. According to the APA "housing 
is not a commodity. It is an all but permanent, all but immovable product that affects the lives not only of those who live in it, but those who live around it, whose experience is powerfully or subtly affected by it. How a house or housing development looks, and how well it works for those who live in it or observe it from the outside, is a matter of paramount importance, whether it is designed to accommodate the neediest or the most affluent." (Mallach, 2009, pg. 53).

Good design can provide benefits in all stages of the development. According to the APA book, designing affordable housing consists of a design considerations checklist, which was pulled from an online source called design advisor. Design Advisor suggests that there are 20 steps to design quality and excellence into affordable housing. The 20 steps are as follows:

1. Start a Design-focused Workbook for the Project.

2. Review Design Advisor resources: the Design Considerations Checklist, the Gallery of Successful Projects and the Tools section.

3. Understand where design fits in the development timeline.

4. Obtain professional design assistance at the very beginning.

5. Analyze target occupants and establish resident-related design goals for the project.

6. Analyze the surrounding neighborhood and establish communityrelated design goals for the project.

7. Analyze the potential site to make sure they can physically accommodate the proposed project and provide easy access to the amenities and services its residents will need.

8. Begin cost analyses. 
9. Assemble the right project design team.

10. Develop a minimum of 3 alternative site plan concepts for the project.

11. Use the Design Considerations Checklist to guide the design process.

12. Use the Operation \& Maintenance Considerations Checklist to reality check the design process.

13. Identify and prioritize the key design components of the project those that will do the most to meet user needs, respond to the context and enhance the neighborhood.

14. Stress the project's design quality in all funding and regulatory applications.

15. Identify and prioritize the key construction materials and systems for the project - those which are most critical to making the project "built to last."

16. Identify and prioritize the key finishes and hardware for the project those which are most critical to making the project "built to last."

17. Monitor bids and review any material, system, finish or hardware substitutions to ensure that design objectives, especially the "built to last" goal, are not compromised.

18. Monitor construction to ensure that all key design, construction and finish goals are being met.

19. Create an operation and maintenance manual for the project.

20. Complete Project Book

As seen in the above 20 steps; they have referred to many times the context of the site as being a key element in good design. The discussions of goals, analyzing surrounding neighborhoods (site context), analyzing the site, development of site concept plans and identifying and prioritizing key design elements such as those that will do the most to meet the user(s) needs by 
responding to the context and enhancing the neighborhood, are key objectives to creating good design from a planners perspective. The Planners perspective differs from that of an Architects perspective. The Planner looks at the outcome of good design to be primarily focused on the site as a whole and its effects on the surrounding neighborhoods.

Within the assessment survey (Appendix B), the questions involving discussion about proximity to surrounding amenities and mode of transportation are more related to questions that would be asked by a Planner. Question 14 and 15 ask, if relevant, where the participant is working and approximately how many miles they are traveling to work. This gives the Planner an idea of how many jobs are staying local to San Luis Obispo and if those living in an affordable unit have to travel excessively outside the area for work. Most often those living within a low income unit generally don't have a car and have to use another form of transportation. However, if many are traveling outside the area for work, this may be a clear sign that the City of San Luis Obispo is lacking jobs. Planners want to know if local amenities are within $1 / 4$ mile radius of a home. The $1 / 4$ mile radius is based off of a distance that is easily walkable by most within a short 10 or 20 minutes time frame. Question 18 helps to answer how conveniently located the majority of affordable units are to these amenities, i.e. groceries, schools, parks, bus stops, bike path, etc., which service basic everyday needs. 
The next section describes the assessment survey in more length and reviews the findings. Many of the questions in the assessment survey were generated to identify houses that are significant for both planners and architects with respect to the design and quality of an affordable home.

\subsection{THE PROCESS OF THE SURVEY}

The surveys that were sent out consisted of questions pertaining to demographics, indoor air quality, building quality, location to local services, amenities and overall likes and dislikes of the home. The surveys were packaged and mailed in November 2011 and allowed the participants two weeks to conduct the survey and mail them back. The survey included a cover letter explaining the purpose of the survey. The surveys also included a return envelope with postage paid, to encourage a quick and easy response.

The expected rate of return was $20 \%$. Whereas the actual rate of return was $30 \%$. The survey responses were manually inputted into Survey Monkey to create charts and diagrams. These charts and diagrams served as the basis for analyzing the quality and design of affordable housing in San Luis Obispo.

The open-ended questions were also inputted into Survey Monkey, but could not be condensed into a chart or graph. However the online program Wordle was used to create a word cloud which made it easy to determine the most common answers 


\subsubsection{Demographic questions}

The demographic questions are common questions asked at the beginning of surveys in order to get a sense of the population that has responded to the questionnaire. They ask for gender, age group and if the participant rents or owns. This allows the survey to be split up into owner and rental categories as well as to see what the common age group is living in the affordable housing units.

\subsubsection{Design/space quality questions}

The next sets of questions involve assessment of the interior spaces, type of home, parking facilities, build quality and amenities in the home. The question examining parking facilities is of great interest. It reveals if the perception that most affordable housing units don't come with garages is true or false for the City of San Luis Obispo. The survey has two tables for the participants to complete. The first asks the participant to specify how many hours a week they spend in the specified rooms; living room, dining room, kitchen, master bedroom, bedroom, bathroom, garage, common spaces and balcony/patio. The evaluation of the returned surveys provide a better idea of which rooms to possible make larger in the future design and construction of affordable units as well as the rooms that more design effort by the designer and contractor should go into to achieve higher satisfaction. The second table asks the participants to rate each room on a scale 1 to 5 based on air quality, ventilation, natural lighting, and heating/cooling. The evaluation of this table 
will provide a better sense of where the physical design of affordable units are lacking and succeeding.

The design and space quality questions are focused more on what makes good design from an architect's point of view. When it comes to residential design, architects are looking at designing for flexibility and cost savings as well as improving energy efficiency. Along with planners, the architects are also interested in "livable neighborhood design such as the accessibility of homes to transit, jobs, shops, park, and public services" (Bohl, 2007, pg. 113). The architects are not only interested in the exterior circulation, but also the flow and circulation of the interior spaces.

\subsubsection{Location/transportation questions}

The questions about the participants' travels and mode of transportation will give helpful insight into if many people living in affordable units have a vehicle or not. One myth about affordable housing projects is that an increase in traffic and congestion will occur because of the high density construction. However, in most cases those who live in affordable housing don't have a car and travel by either, walking, biking or taking transit. For the participants who are currently working, it will be interesting to see how far from their home they have to travel to get to their jobs. In many cases people may find themselves traveling outside of their city for work. However, in the case of San Luis Obispo, many people are traveling into town for work from the north and south counties. 


\subsubsection{User perception questions}

The last few questions are open-ended questions asking the participants for features they like and dislike about their home. The answers to these questions will show what aspects of a home are the most important to occupants and what portion of the home a designer or contractor should focus the most on. Also space for additional comments was created for any further information the participants feel is the utmost important.

\subsection{SURVEY YIELD}

A total of 231 surveys were mailed out. After a 2 week turn around, 89 surveys were returned. However, 17 were retuned as vacant and 2 were returned as no such number, leaving 70 surveys ( $30 \%$ rate of return) to analyze. Many of the respondents were within the 65 or older age group, mostly due to the fact that approximately 50 out of 231 surveys were sent to affordable senior housing residences. Out of the 50 surveys sent, 27 surveys (54\% rate of return) were returned from the 65 or older age group, where 24

of the surveys ( $48 \%$ rate of return) were from the senior housing developments; Judson Terrace and Carmel Housing. The residents in senior housing developments had a lot to say in the open-ended questions, which will be discussed later in this section. However, first the overall results to the multiple choice/check box questions will be examined followed by the openended questions. After discussion about the overall results, further analysis was done by splitting the findings into separate categories: senior response analysis, owner response analysis and renter response analysis. 


\subsection{OVERALL RESPONSE ANALYSIS}

\subsubsection{MULTIPLE CHOICE QUESTIONS}

1. Sex:

As seen in the chart above, large percentages (59.4\%) were females who responded to the survey, whereas $40.6 \%$ were male respondents.

Figure 11 Sex.

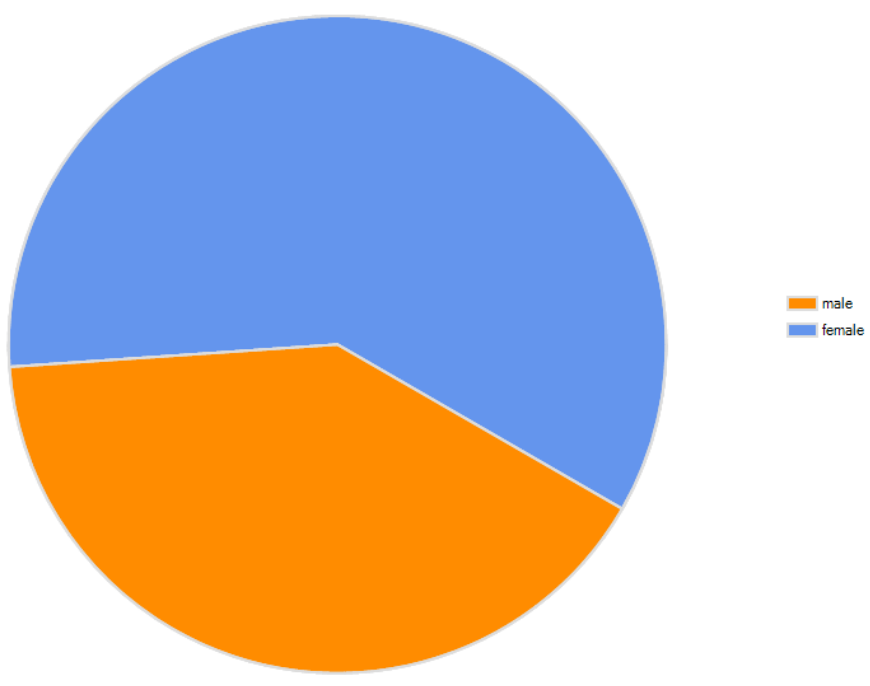

2. Age Group:

The dominant age of respondents was from the over 65 years or older group (39.1\%), reasons discussed earlier, and followed by 2635 years of age at $20.3 \%$. 
Figure 12 Age Group.

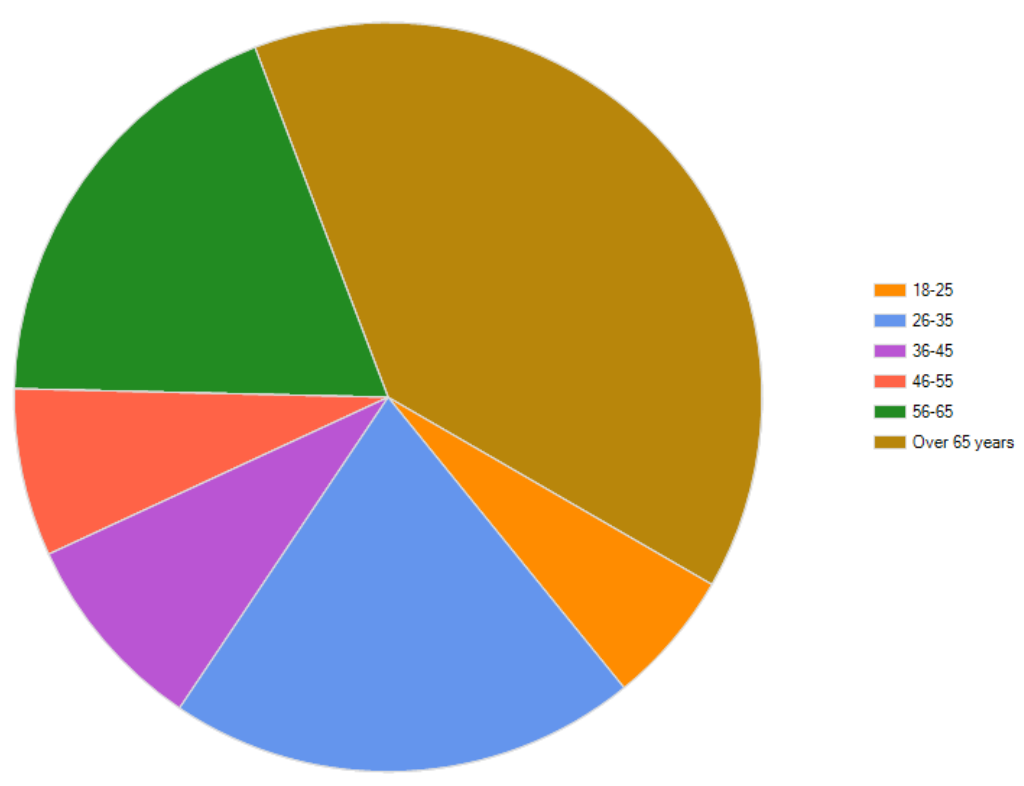

3. Do you rent or own?

Out of the 231 surveys that were sent out about $25 \%$ were owner occupied units.

Figure 13 Do you Own or Rent Analysis.

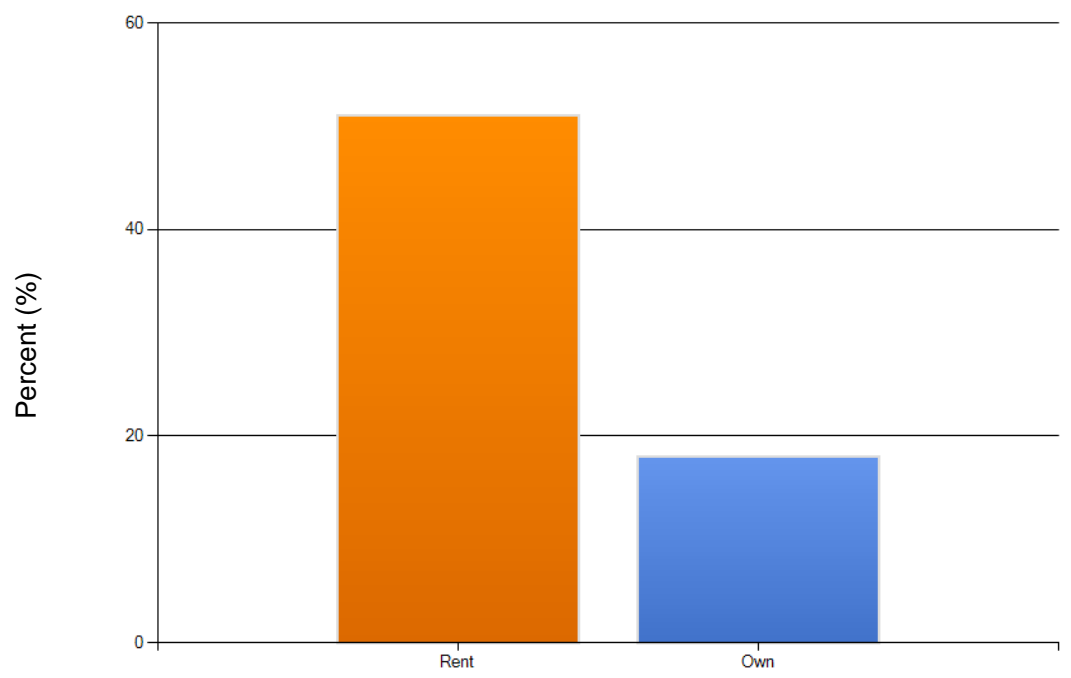




\section{How many bedrooms?}

$52.9 \%$ of the respondents live in a 1 bedroom 1 bath affordable unit which includes mostly rental units. Whereas, the owner occupied units ranged from 2 bedroom to 4 bedroom.

Figure 14 How Many Bedrooms Analysis.

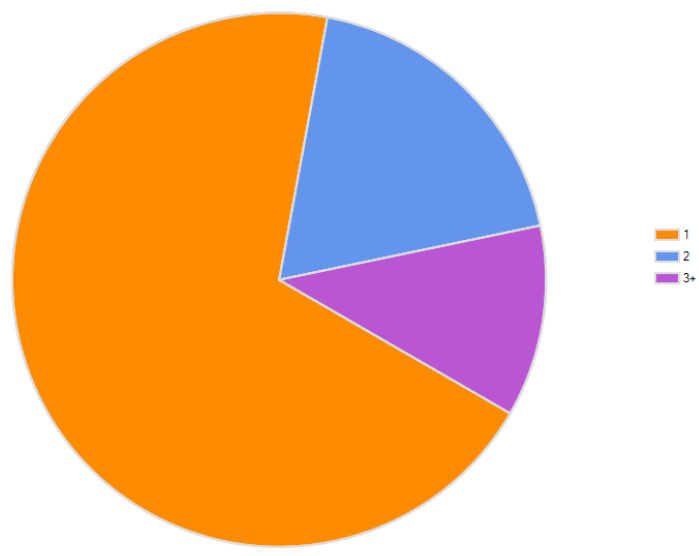

5. How many bathrooms?

Overall, the majority at $69.6 \%$ only had 1 bathroom, followed by $18.8 \%$ with 2 bathrooms and $11.6 \%$ with 3 or more bathrooms within the home.

Figure 15 How Many Bathrooms Analysis.

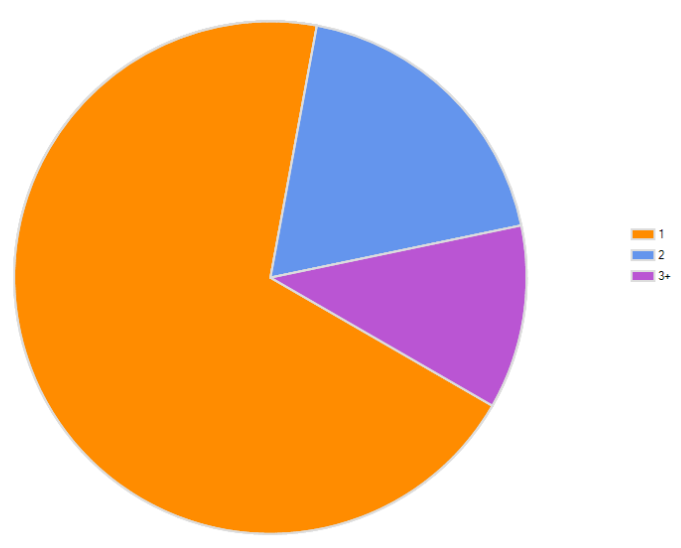


6. What type of home do you live in?

A large number (69.8\%) of affordable units are considered Multifamily (apartment style) units by the respondents. These units were mostly rental units, where the owner occupied units were the small number $(7.9 \%)$ of SFR detached homes as well as the semidetached home (shared wall).

Figure 16 Type of Home Analysis.

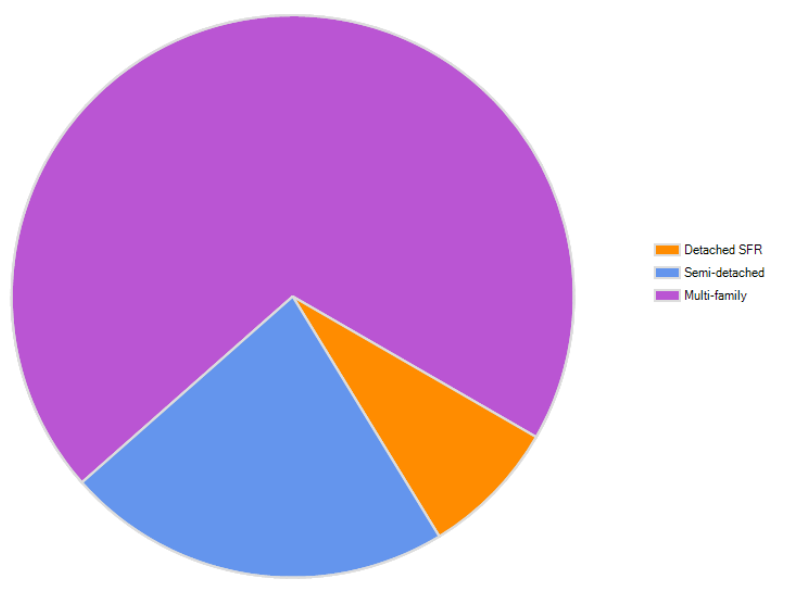

7. Which of the following parking facilities do you have?

The majority of the respondents (49.2\%) are provided with open air designated parking spots, however surprising enough $35.4 \%$ have garages. Most of those with garages are those that are owner occupied units. 
Figure 17 Parking Facilities Comparison.

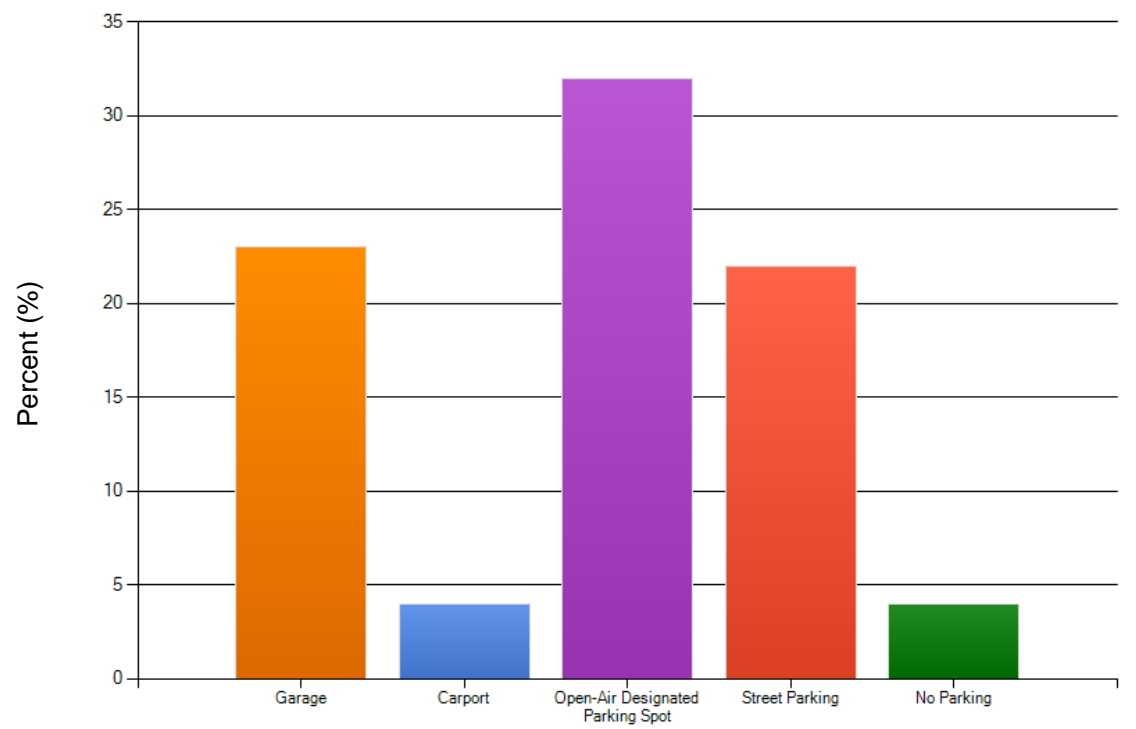

8. All in all, how would you rate the build quality and condition of your home?

The overall response to the build quality and condition of the home, almost $50 \%$ (32 respondents) felt that their home was overall in excellent shape.

Figure 18 Build Quality and Condition.

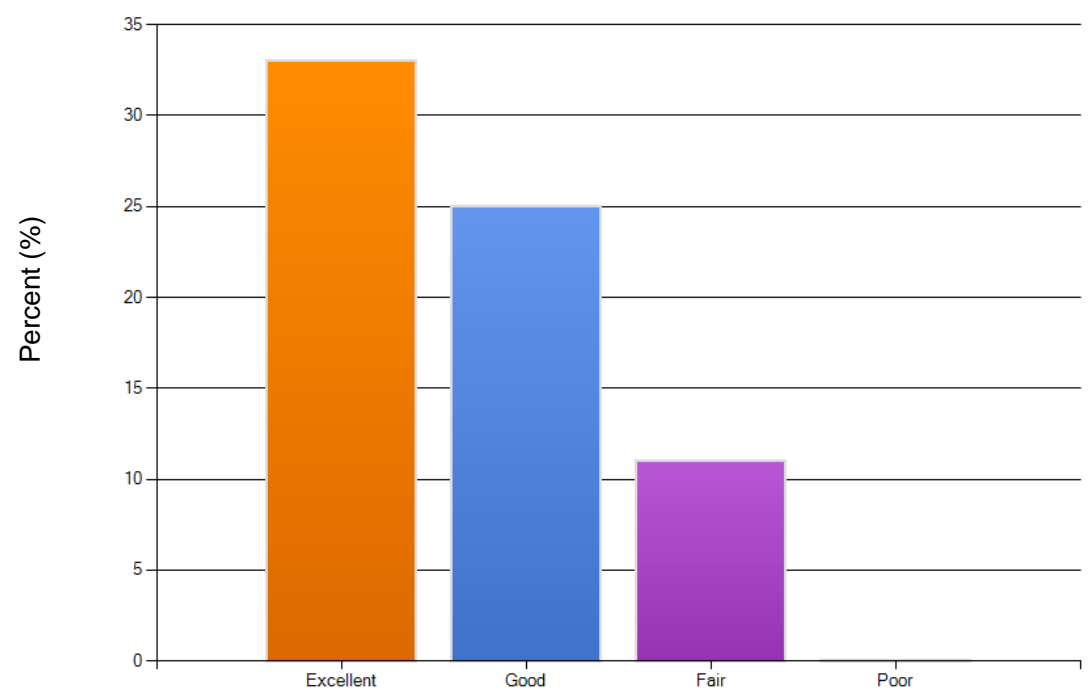


9. Do you have energy saving appliances? (energy star, water saving) About $58 \%$ have energy star or energy efficient appliances in their home.

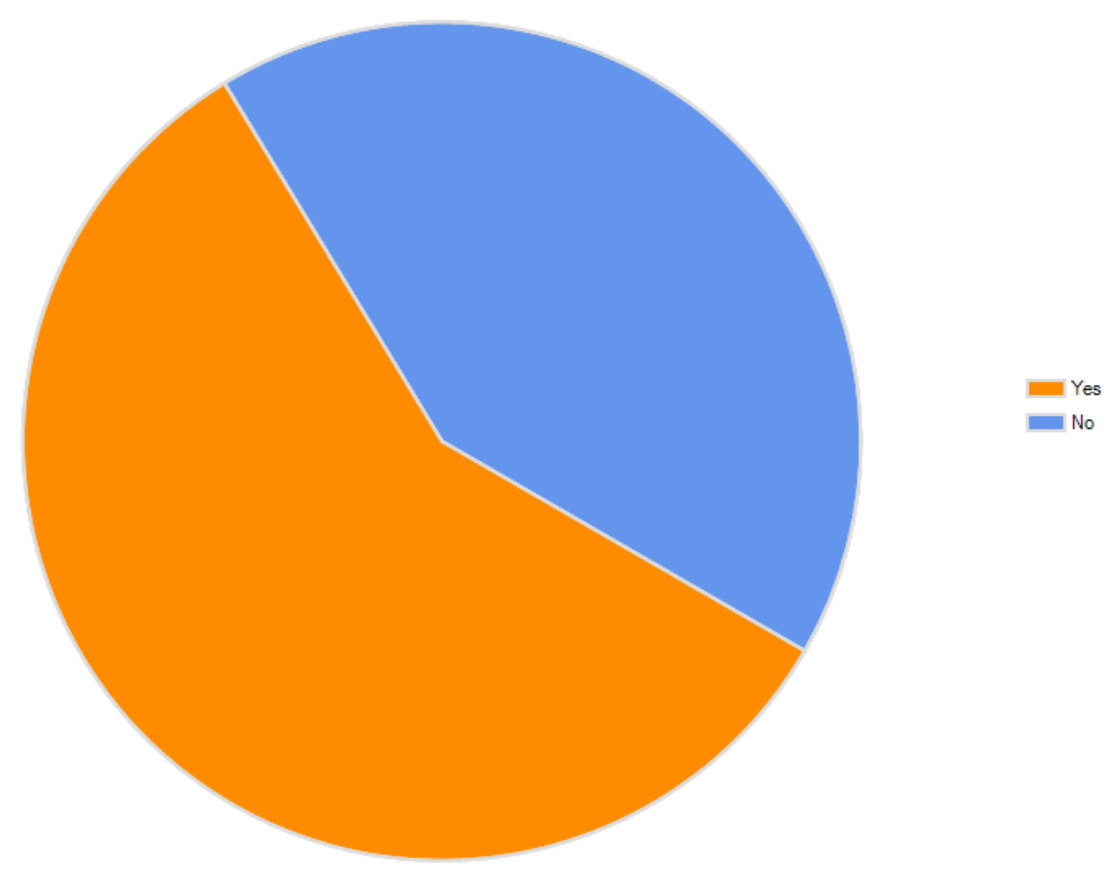

10. If so, which of the following are energy saving appliances?

Most of which are refrigerators followed by washers.

11. In an average work week, how many hours do you spend in the following types of spaces: (place a check mark in the appropriate box)

The chart above indicates that the Master bedroom is the most used space followed by the living room, whereas on the opposite of the scale the balcony and common space are the least used 
spaces. The common space can refer to hallways and/or community space as seen in the senior housing.

Figure 20 Parameter to Local Amenities.

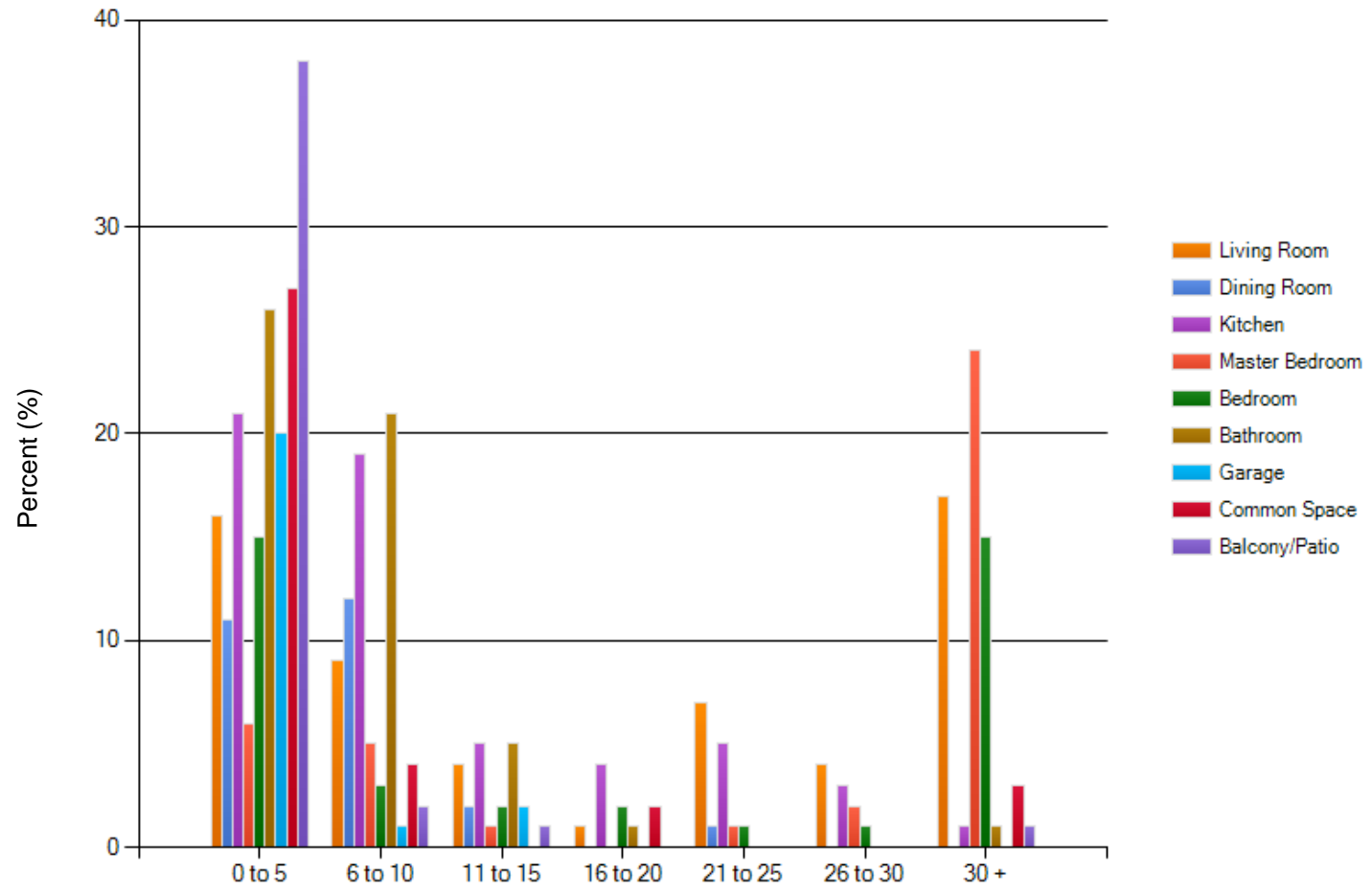

\subsubsection{SCALE RATING QUESTIONS}

12. Please rate the following on a scale from 1 (poor) to 5 (excellent) for the areas specified in the chart. (please write in 1,2,3,4 or 5 in the boxes)

The majority felt as though the air quality, ventilation, natural lighting and heating/cooling of the home was near to excellent. Those whom rated the categories closer to poor were mostly from the senior housing units. 
Table 1. Results from Assessment Survey rating Air Quality, Ventilation, Natural Lighting and Heating/Cooling of one's home.

Please rate the following on a scale from 1 (poor) to 5 (excellent) for the areas specified in the chart.

\begin{tabular}{|c|c|c|c|c|c|}
\hline \multicolumn{6}{|l|}{ Air Quality } \\
\hline Scale & 1 & 2 & 3 & 4 & 5 \\
\hline \begin{tabular}{|l|} 
Living Room \\
\end{tabular} & 2 & 6 & 13 & 18 & 28 \\
\hline \begin{tabular}{|l|} 
Dining Room \\
\end{tabular} & 1 & 2 & 6 & 11 & 20 \\
\hline Kitchen & 3 & 6 & 14 & 15 & 24 \\
\hline Master Bedroom & 2 & 3 & 8 & 10 & 20 \\
\hline \begin{tabular}{|l|} 
Bedroom \\
\end{tabular} & 1 & 5 & 11 & 8 & 22 \\
\hline Bathroom & 4 & 10 & 11 & 13 & 22 \\
\hline \multicolumn{6}{|l|}{ Ventilation } \\
\hline Scale & 1 & 2 & 3 & 4 & 5 \\
\hline Living Room & 2 & 4 & 17 & 14 & 28 \\
\hline Dining Room & 1 & 3 & 8 & 11 & 16 \\
\hline Kitchen & 5 & 9 & 14 & 15 & 19 \\
\hline Master Bedroom & 2 & 2 & 10 & 10 & 17 \\
\hline Bedroom & 1 & 6 & 11 & 11 & 18 \\
\hline Bathroom & 9 & 9 & 13 & 9 & 17 \\
\hline \multicolumn{6}{|l|}{\begin{tabular}{|l|} 
Natural Lighting \\
\end{tabular}} \\
\hline Scale & 1 & 2 & 3 & 4 & 5 \\
\hline Living Room & 6 & 8 & 9 & 17 & 25 \\
\hline Dining Room & 4 & 3 & 7 & 11 & 15 \\
\hline Kitchen & 15 & 4 & 9 & 15 & 17 \\
\hline Master Bedroom & 4 & 4 & 10 & 7 & 17 \\
\hline \begin{tabular}{|l|} 
Bedroom \\
\end{tabular} & 3 & 6 & 9 & 8 & 20 \\
\hline Bathroom & 21 & 7 & 9 & 7 & 12 \\
\hline \multicolumn{6}{|l|}{ Heating/Cooling } \\
\hline Scale & 1 & 2 & 3 & 4 & 5 \\
\hline Living Room & 5 & 6 & 18 & 12 & 22 \\
\hline \begin{tabular}{|l|} 
Dining Room \\
\end{tabular} & 3 & 2 & 13 & 10 & 12 \\
\hline \begin{tabular}{|l|} 
Kitchen \\
\end{tabular} & 3 & 8 & 18 & 13 & 18 \\
\hline Master Bedroom & 3 & 5 & 9 & 8 & 15 \\
\hline Bedroom & 3 & 6 & 10 & 9 & 17 \\
\hline Bathroom & 5 & 8 & 13 & 9 & 19 \\
\hline
\end{tabular}


13. If you are currently working, where is your job located?

The majority of the respondents (84.4\%) work in San Luis Obispo followed by 5 cities and Santa Maria at $6.3 \%$.

Figure 21 Location of Job.

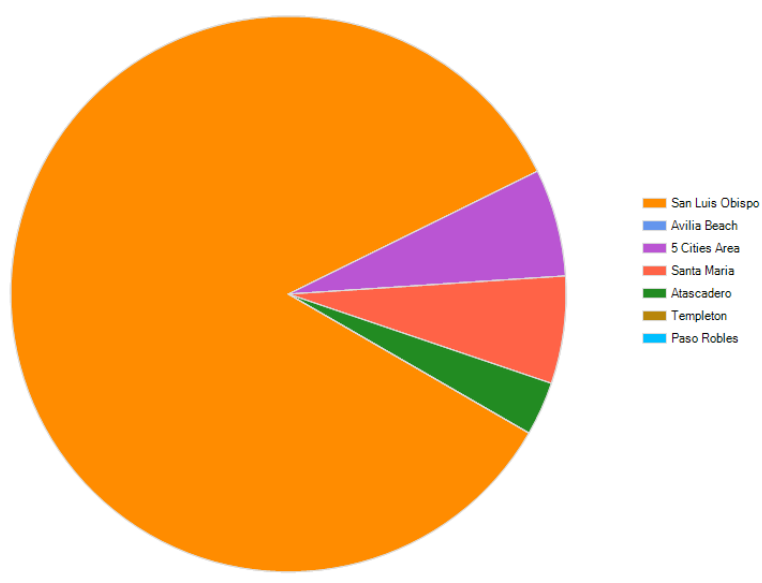

14. How far do you travel to work?

Since the overall respondents worked in San Luis Obispo, 54.1\% traveled anywhere from 0 to 5 miles to work. Whereas, $16.2 \%$ travels 5 to 10 miles, $13.5 \%$ travel 10 to 15 miles and $16.2 \%$ travel 15 or more miles to work.

Figure 22 Miles Traveled to Work.

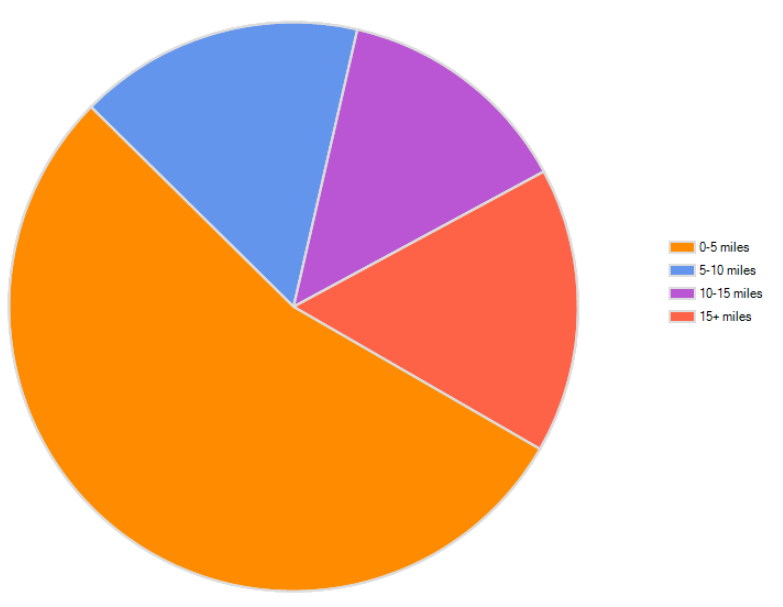


15. What is your primary mode of transportation?

The primary mode of transportation at $82.1 \%$ was auto, followed by bus at $9 \%$, bike at $6 \%$ and walking at $3 \%$.

Figure 23 Primary Mode of Transportation.

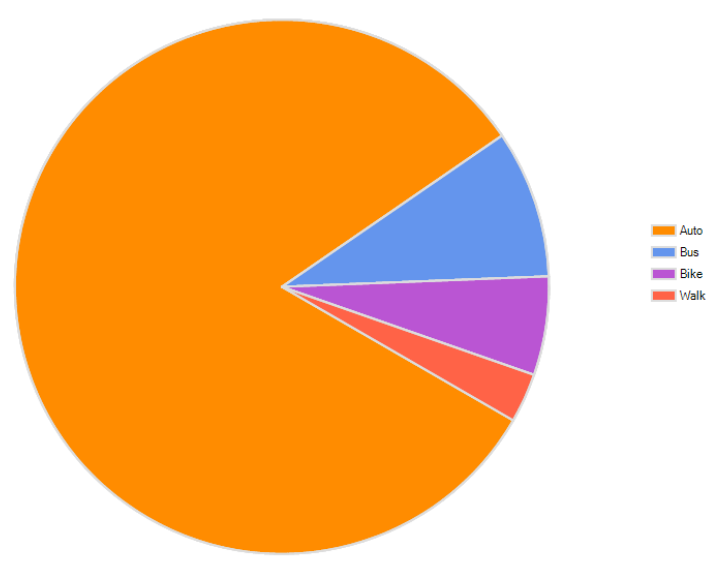

16. What is your secondary mode of transportation?

Besides using the automobile for transportation many responded saying they either don't have a secondary mode of transportation $(31.1 \%)$ or they walk (36.1\%). $16.4 \%$ of the respondents use a bike as a secondary mode of transportation, followed by a bus at $8.2 \%$.

Figure 24 Secondary Mode of Transportation.

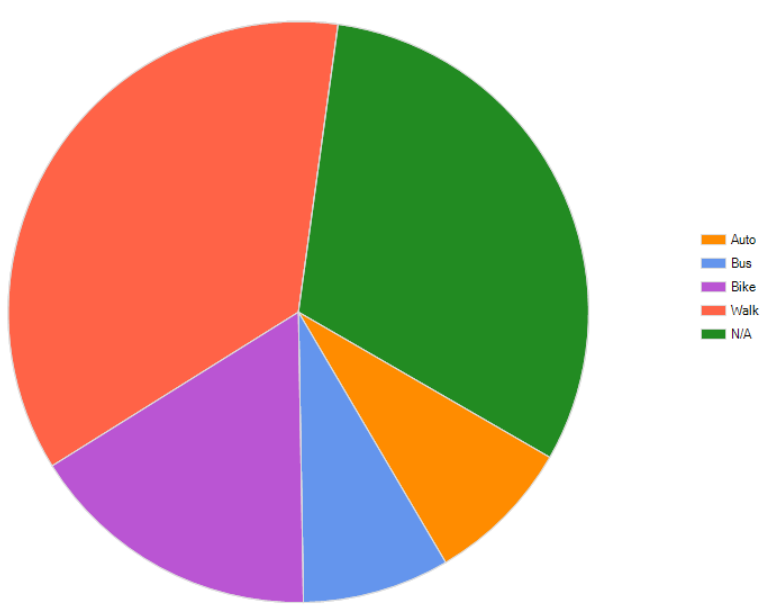


17. Please place a check mark in the following boxes to indicate distances to surrounding services in relation to your home?

As far as near-by amenities, most of the affordable housing units were within walking distance and/or $1 / 4$ mile radius of bus stops, parks, laundry facilities, shopping and bike paths. The furthest amenity was medical facilities and groceries.

Figure 25 Parameters to Local Amenities.

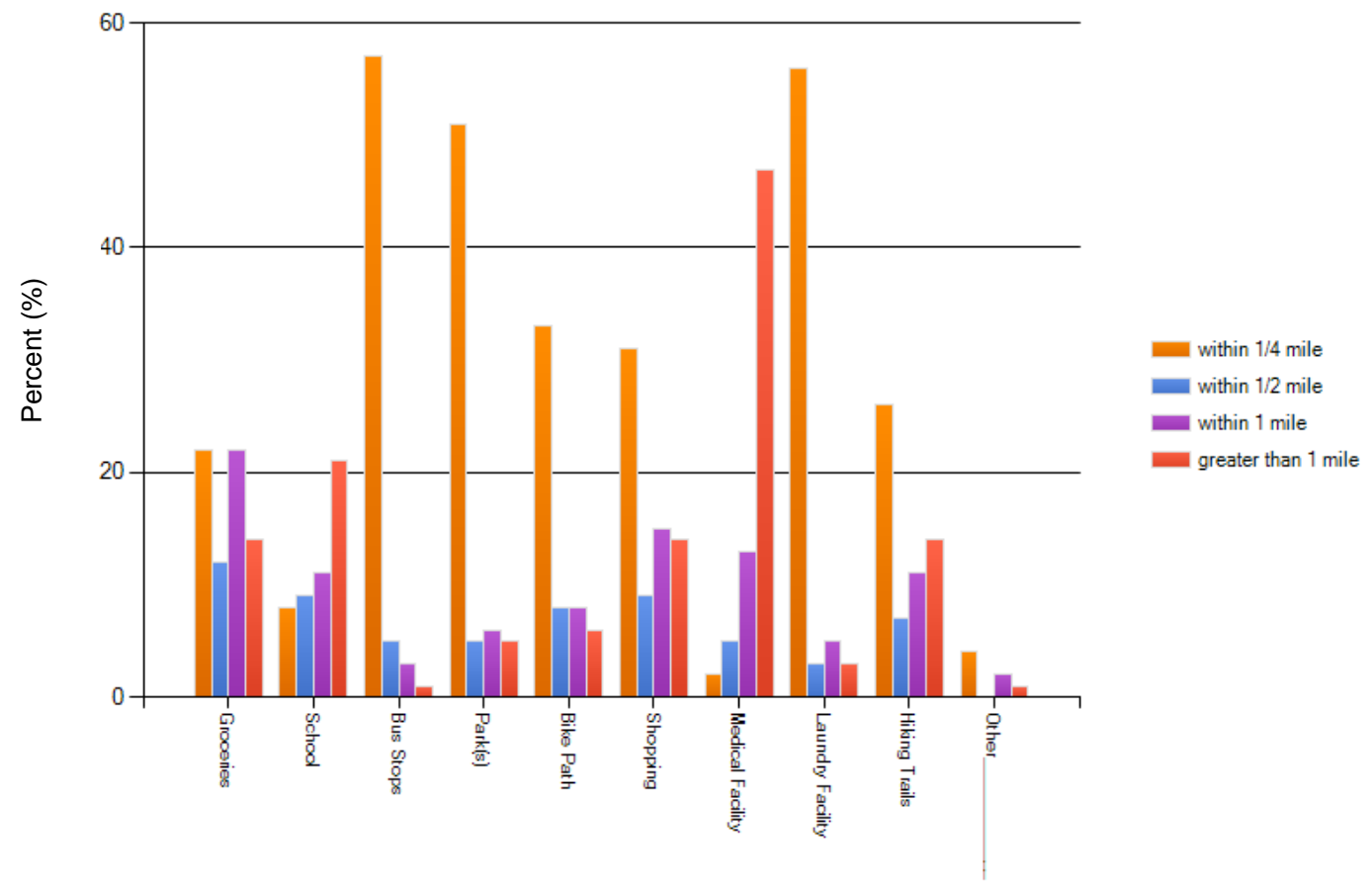

\subsubsection{OPEN-ENDED QUESTIONS}

18. If you could change 3 things about your home what would those be?

For the most part the respondents did not want to change much with their homes. A few respondents mentioned more light and windows would be nice, as well as a garage and better heating. 
However, the question arises, have these responses been

influenced by the previous question regarding air quality, ventilation, natural lighting and heating/cooling? This may be hard to determine. (Appendix G-1)

19. List the features of your home you are most satisfied with? The location of the homes was the most popular answer. Most of the units were very satisfied with being able to live in San Luis Obispo. Also they were very satisfied with having on-site laundry facilities as well as the closeness to downtown. (Appendix G-1) In comparison to the national trends, this overall analysis appeared to outshine those statistics. The City of San Luis Obispo is located within one of the highest median home value brackets in California, which is why a considerable amount of affordable housing is important to the area. However, many would assume in an area similar to San Luis Obispo it would be difficult to obtain an affordable home due to high housing costs and low median income. San Luis Obispo's affordable housing standards prove differently. The ranges that are considered lower or moderate income are much greater then compared to other cities. This is what allows a large percentage of the population to become eligible for an affordable unit. This data collected has proven that living in an affordable unit is really no different than living in a market rate home except for the cost savings.

The data showed that more parking is available than assumed. Generally income has a dramatic effect on vehicle ownership, the higher the 
income the more vehicles per household. However, according to the collected data all the affordable units in San Luis Obispo have access and available parking, if it is garages, carport parking or street parking. Almost $50 \%$ of all affordable units in the City have a designated parking spot associated with their unit. $35.4 \%$ of the units were equipped with a garage, whereas a small $4 \%$ stated they had no parking. The rest either had shared parking or a carport. The City provides more parking for their affordable units than other cities, which makes it easier for the community to choose to have their primary mode of transportation as a vehicle rather than a bike or taking transit. $82.1 \%$ of the participants stated that they use their car as a primary mode of transportation followed by $9 \%$ who take the bus. Although many of the people work in the City (84.4\%) they still choose to drive to work than any other mode of transportation. Although San Luis Obispo's cost of living is deemed higher nationally, those living in the affordable units are able to live in San Luis Obispo and work locally. Those who are seeking market rate housing are buying homes outside the area because of high market rate costs and needing to commute into San Luis Obispo where the majority of jobs are located.

Although the overall analysis showed many of the participants use a car rather than the bus to get around the City, the locations of $55 \%$ of the affordable units were within $1 / 4$ mile of a bus stop. The $1 / 4$ mile distance is generally equivalent to a 20 minute walk. More than $30 \%$ of all affordable units were located within $1 / 4$ mile radius of laundry facilities, parks, bike lanes 
and hiking trails. This statistic proved that the locations of the current affordable housing stock were planned with local services in mind. Overall the current affordable housing stock serves the current renters, owners and seniors with near-by amenities, plenty of parking and jobs within the City.

\subsection{SENIOR RESPONSE ANALYSIS}

The vast amounts of responses were returned by the senior age group of 65 or older as noted earlier. The majority of the responses were received from the local senior affordable housing facilities; Judson Terrace and Carmel Apartments. This analysis deemed as important due to the number of responses received. The senior community had a lot of information to share and discuss. There were a few responses received from the 65 or older age group that were not associated with the above listed senior housing, however this analysis focuses only on those responses from the senior housing.

\subsubsection{MULTIPLE CHOICE QUESTIONS}

1. Sex:

The responses from the senior respondents came back as $50 \%$ for both male and females.

Figure 26 Sex.

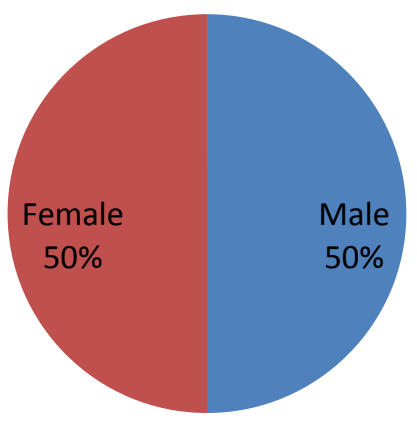


2. How many bedrooms?

$96 \%$ of the seniors live in 1 bedroom homes with 1 bath, whereas $4 \%$ live in studios.

Figure 27 Bedrooms

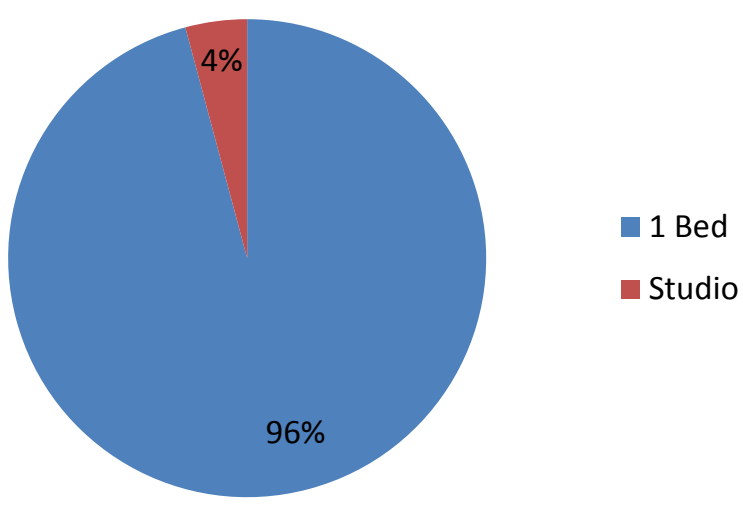

3. Which of the following parking facilities do you have?

The majority of the senior housing facilities have open-air designated parking spaces (50\%) where $38 \%$ off them have street parking. Many of the respondents don't have cars and don't use or need parking facilities.

Figure 28 Parking Facilities.

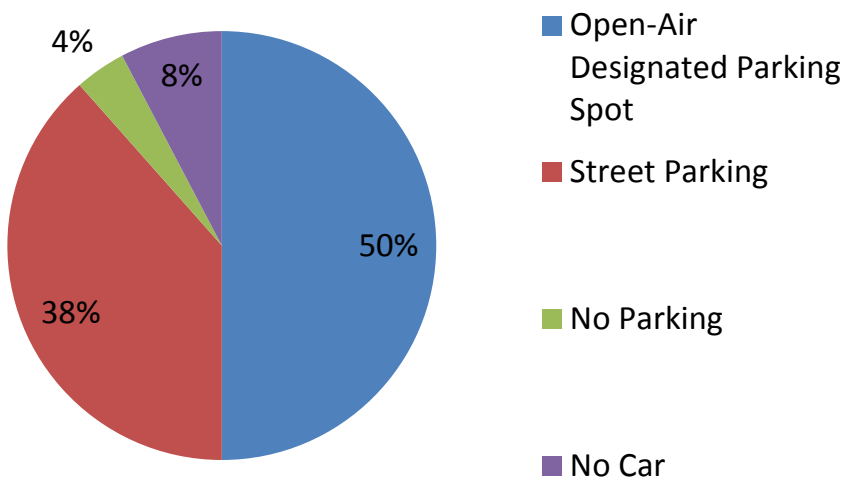


4. All in all, how would you rate the build quality and condition of your home?

$50 \%$ of the seniors rated their homes in excellent condition; however a high percentage (42\%) ranked their home a good condition. Only $8 \%$ ranked their home at poor quality.

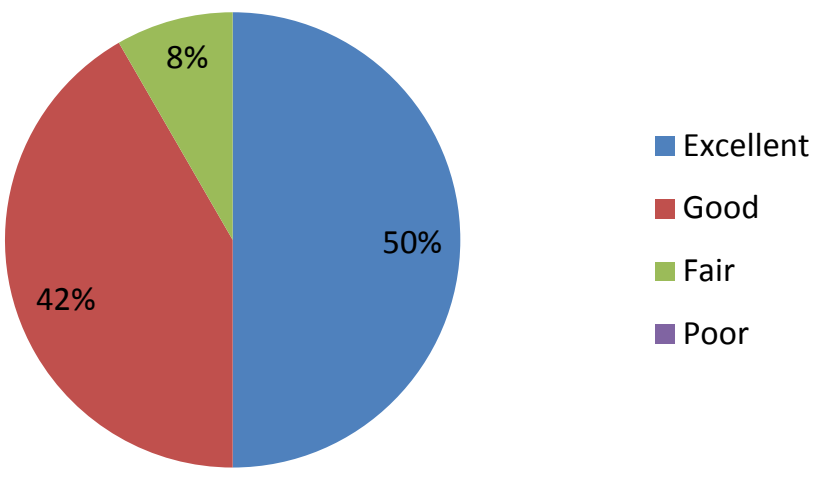

5. Do you have energy saving appliances?

$54 \%$ of the senior housing facilities had energy saving appliances.

Although the majority of the respondents had energy saving appliances, those that were laundry related were located on the property, but not necessarily within the home. 


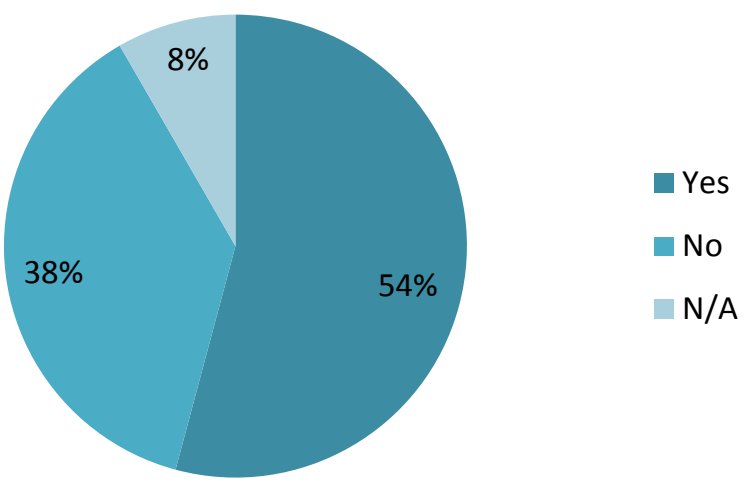

6. If so, which of the following are energy saving appliances?

$33 \%$ of the respondents have energy saving refrigerators followed by $10 \%$ having washer, dryers and water heaters.

Figure 31 Types of Energy Saving Appliances.

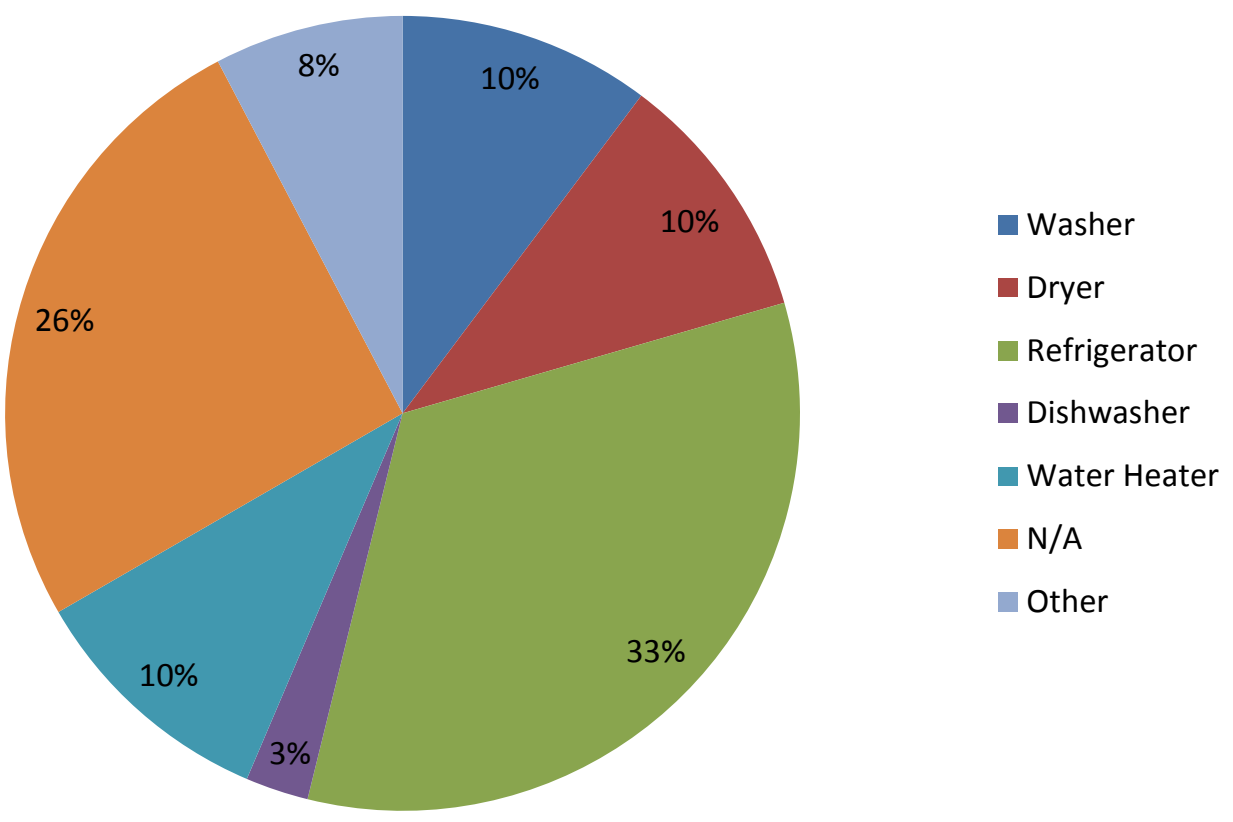


7. In an average work week, how many hours do you spend in the following types of spaces?

This question was a little confusing for the seniors, since the facility has many shared spaces; such as the dining room and kitchen.

Since many of the respondents have a living room and master bedroom within their unit, the hours spent within these spaces ranked at the highest (30 hours). The 0 to 5 hours range ranked high in the common space and balcony/patio spaces.

Figure 32 Hours Spent in Spaces of the Home.

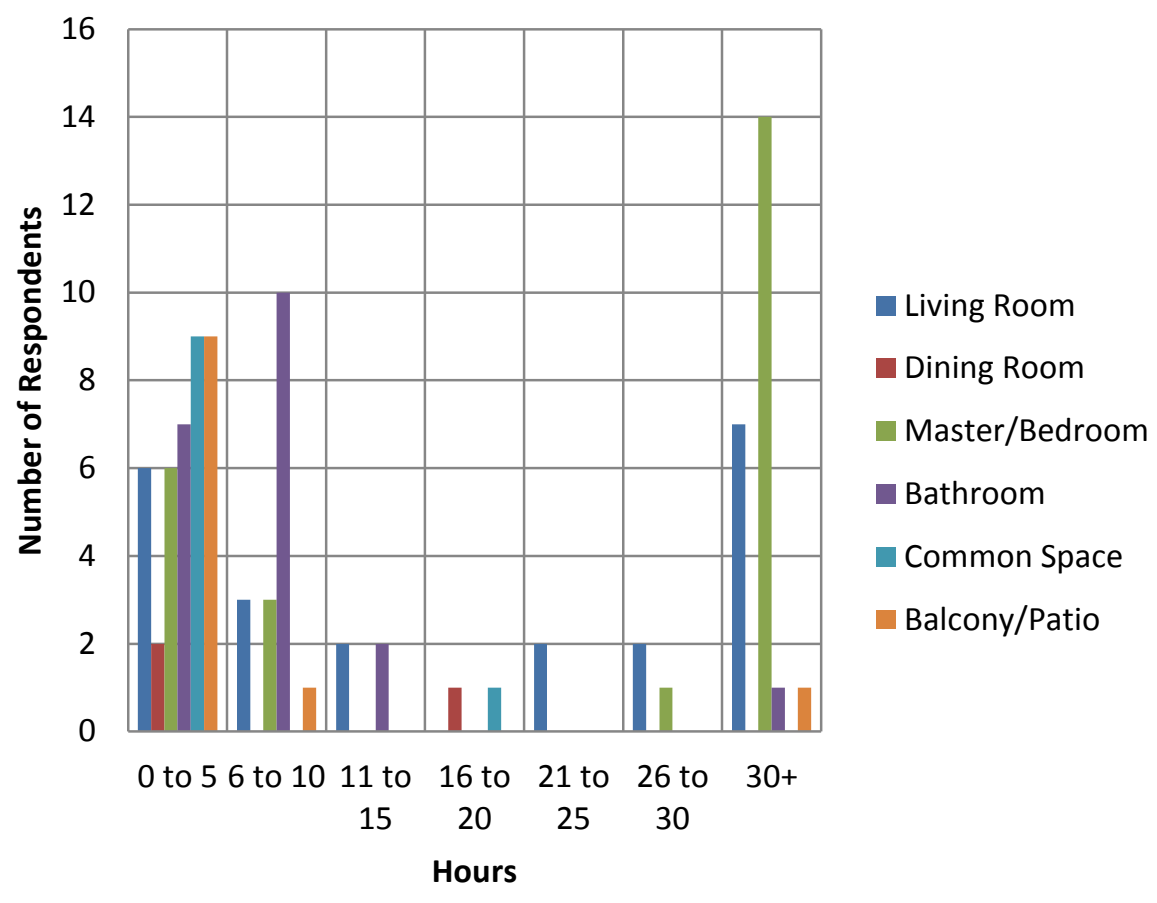

\subsubsection{SCALE RATING QUESTIONS}

8. Please rate the following on a scale from 1 (poor) to 5(excellent) for the areas specified in the chart. 
As far as air quality the respondents thought overall all rooms were excellent. However, a few thought the bathroom and master bedroom were closer to poor air quality rather than excellent. The respondents rated ventilation of the living room, master bedroom and kitchen in the excellent category. The dining room and bathroom appeared to be thought of as poorly ventilated spaces. This category was unbalanced. Many thought the kitchen had excellent natural lighting, but at the same time a large percentage thought the natural lighting was poor. The master bedroom and living room were ranked at good to excellent in the natural lighting category. However, the bathroom natural lighting ranked low, with many implying they either didn't have a window in the bathroom or that it was quite small. The heating and cooling category overall came back with a good to excellent response. The only space that ranked low was again the bathroom. 
Figure 33 Rating of Air Quality.

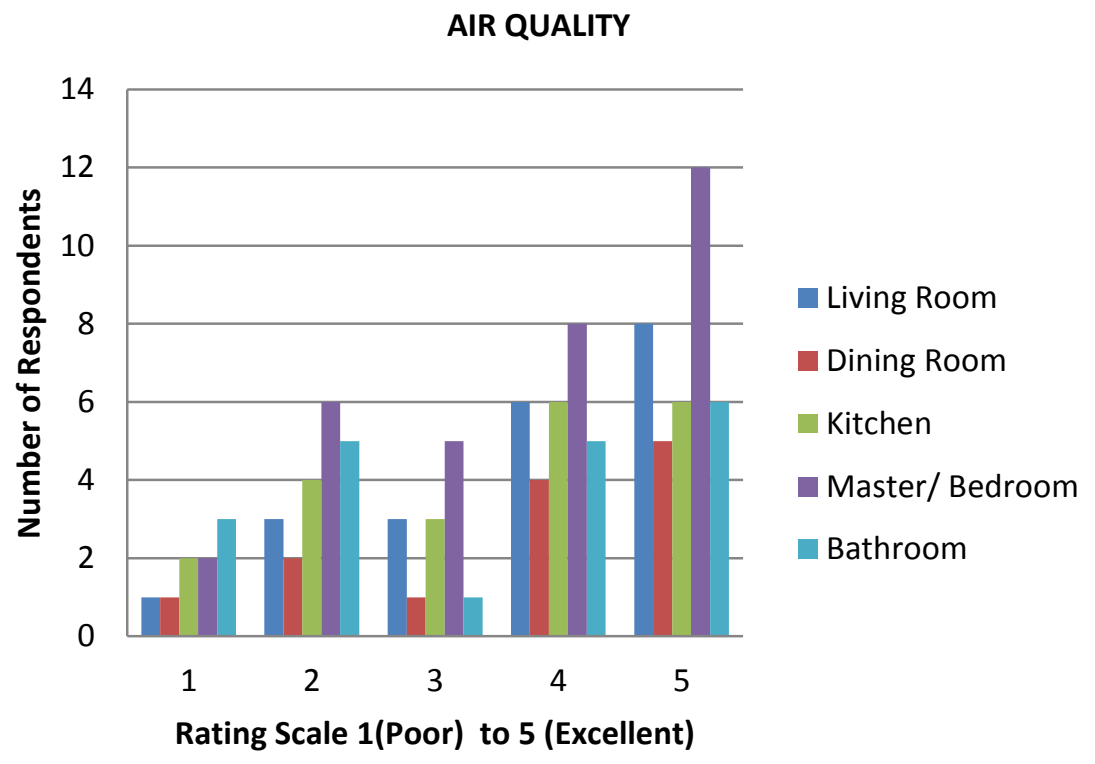

Figure 34 Rating of Ventilation.

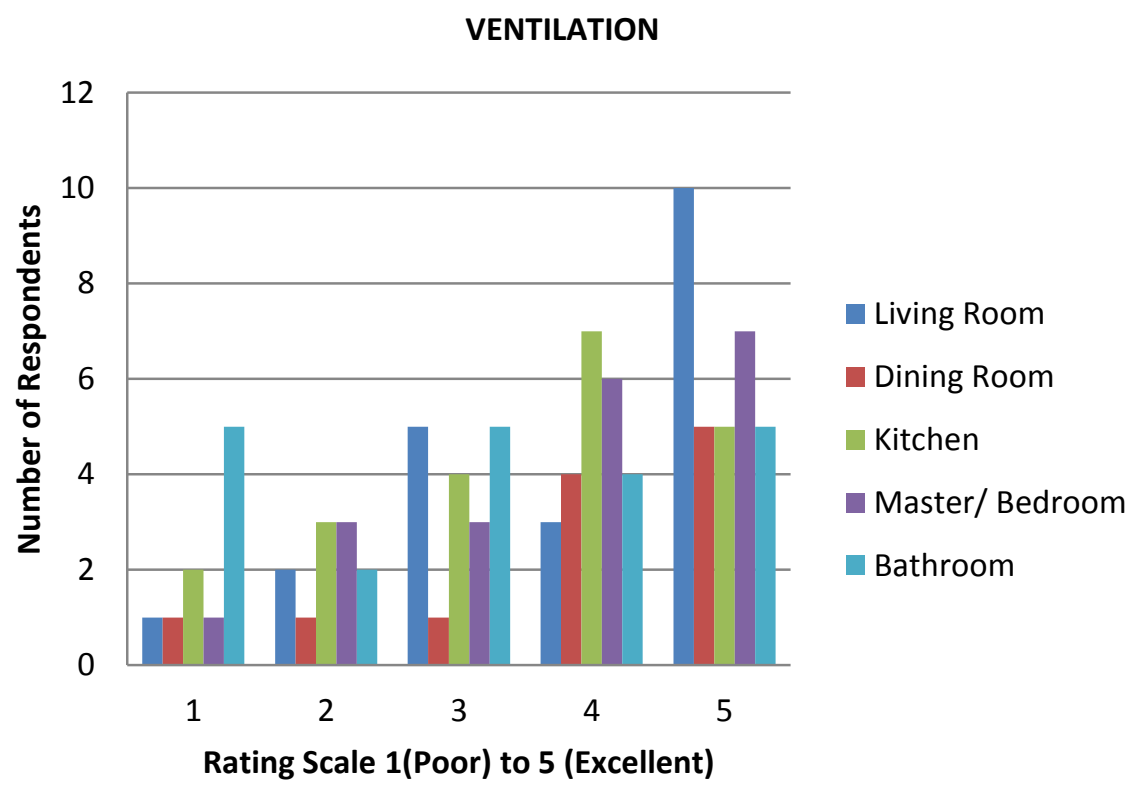


Figure 35 Rating of Natural Lighting.

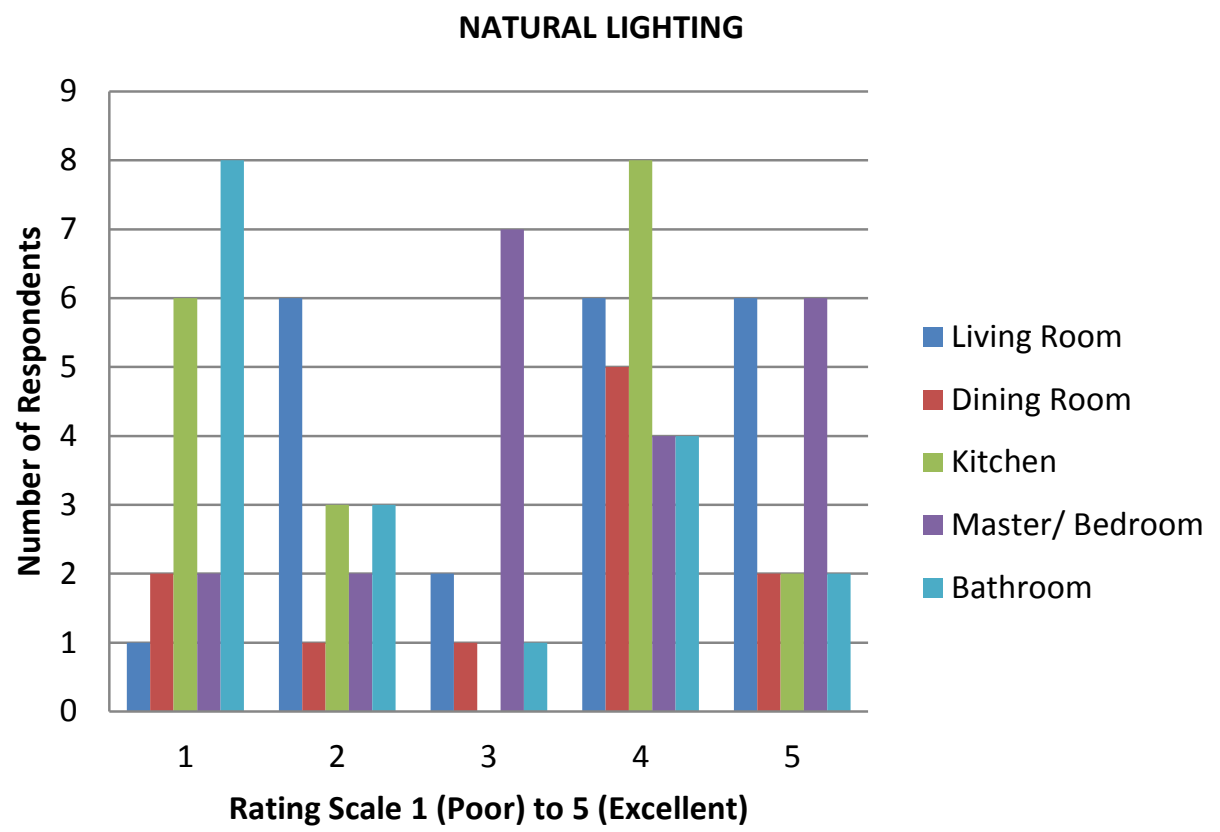

Figure 36 Rating of Heating/Cooling.

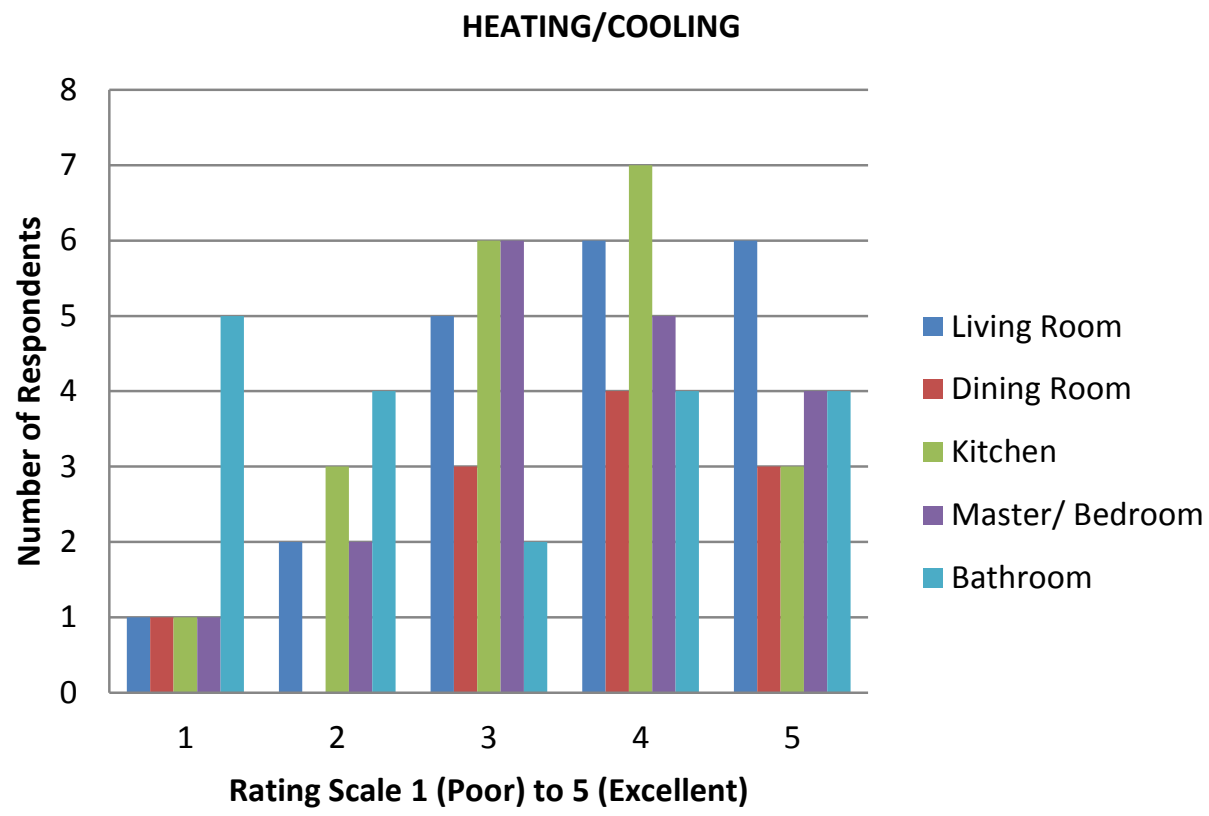


9. What is your primary mode of transportation?

Figure 37 Primary Mode of Transportation.

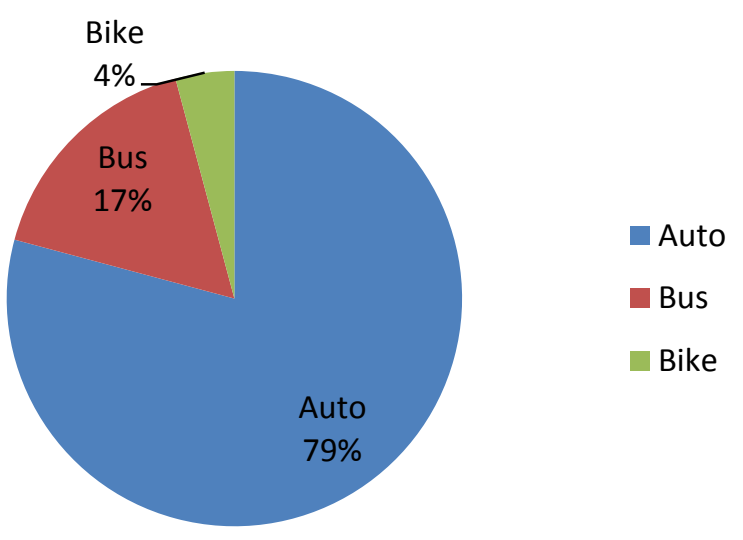

The majority at $79 \%$ preferred to use their automobile, where a few at $17 \%$ took the bus and even fewer (4\%) use a bike.

10. What is your secondary mode of transportation?

$56 \%$ would walk if they were not using their cars. Whereas around $15 \%$ the rest would bike, carpool or take the bus.

Figure 38 Secondary Mode of Transportation.

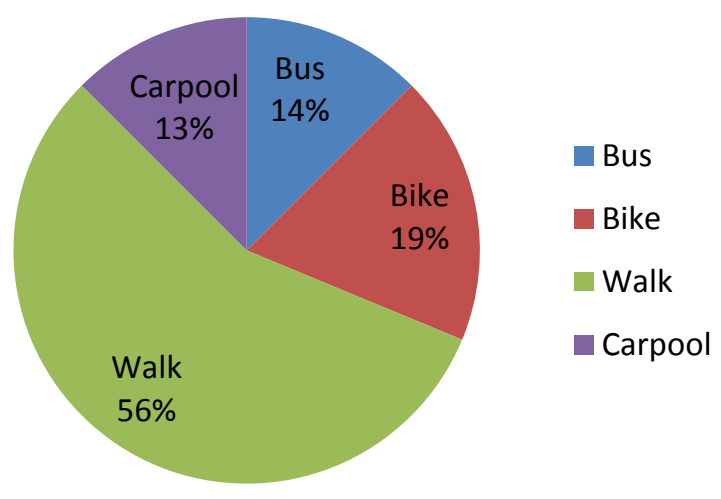

11. Indicate distances needed to travel to surrounding services. 
The facilities found mostly within $1 / 4$ mile of the home where: laundry facilities (most on-site), bus stops, parks and bike paths. This assumes these four facilities are within a 20 minute walking distance from someone's home. The remainder amenities would require further walking distances and/or the use of a vehicle, bus or bike in order to get to them.

Figure 39 Parameters to Local Amenities.

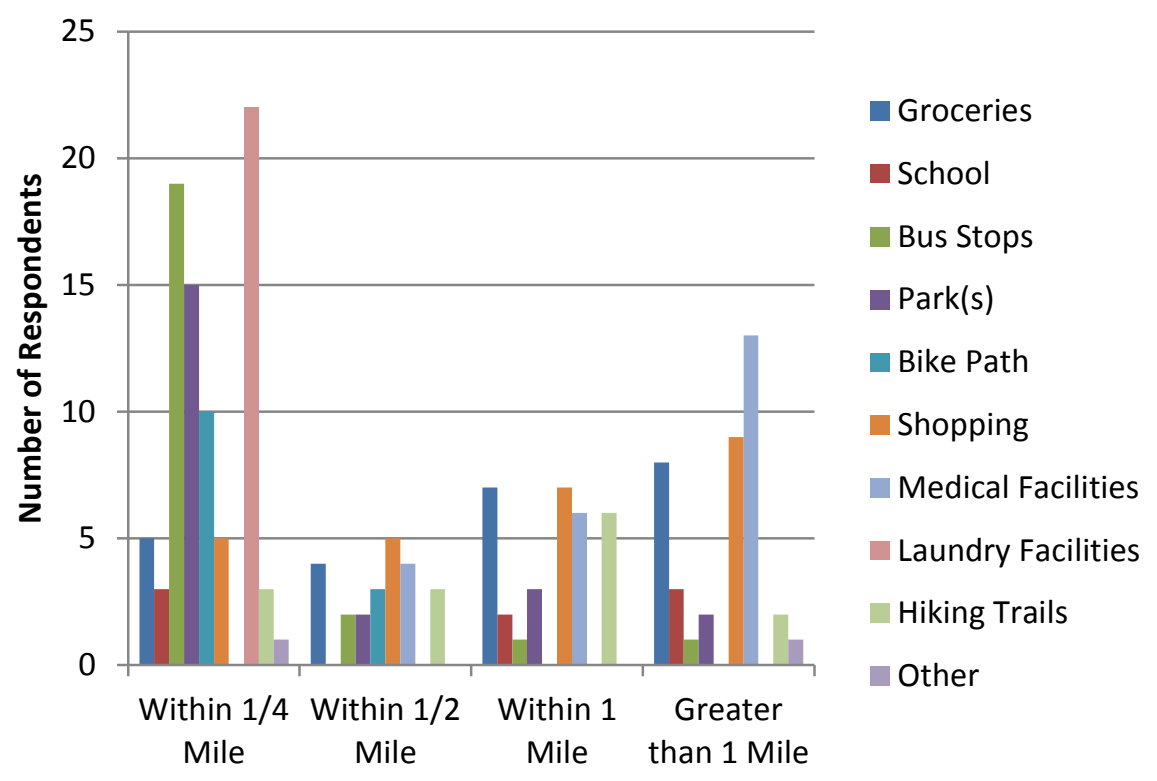

\subsubsection{OPEN-ENDED QUESTIONS}

12. If you could change 3 things about your home what would those be?

The top responses included wanting more parking and/or handicapped parking closer to the units, more windows to provide natural lighting, change out old dirty carpet for new carpet, better lighting and less noise was preferred. (Appendix G-2)

13. List the features of your home that you are most satisfied with? 
The top responses included the cost of rent, on-site laundry facilities, and views surrounding units, neighbors, management, and proximity to downtown and common spaces. (Appendix G-2)

The senior responses were a bit different from the overall analysis. Since many of the seniors were retired and not working they were not traveling within or outside the City for work. However, many would assume seniors would not own a vehicle or be driving. A high $79 \%$ of the seniors who responded stated their primary mode of transportation was the automobile. A larger percentage (17\%) did take the bus as a primary mode of transportation where the overall analysis showed a low $9 \%$. This is most likely due to fewer individuals having vehicles. Again, more than 30\% stated laundry facilities, parks, bus stops and bike paths were all within a 1/4mile radius of their home. When it came to overall quality and design, the senior responses had a bit more to say and rated the conditions predominately in the fair category; however, no ratings were labeled as poor conditions.

\subsection{OWNER RESPONSE ANALYSIS}

\subsubsection{MULTIPLE CHOICE QUESTIONS}

1. Sex:

The majority of the owner respondents were males at $82 \%$. 
Figure 40 Sex.

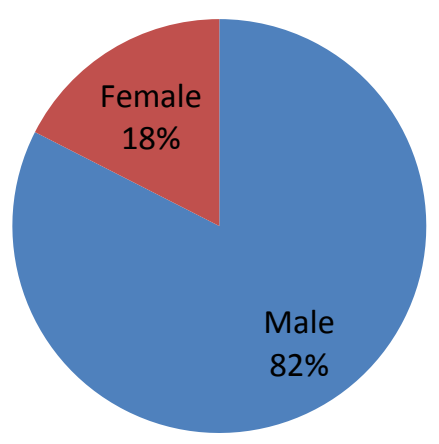

\section{Age Group:}

$50 \%$ of the owner responses were between the age group of $26-35$ years of age. This was followed by $36-45$ years (21.4\%) and $56-65$ years $(14.29 \%)$.

\section{Figure 41 Age Group.}

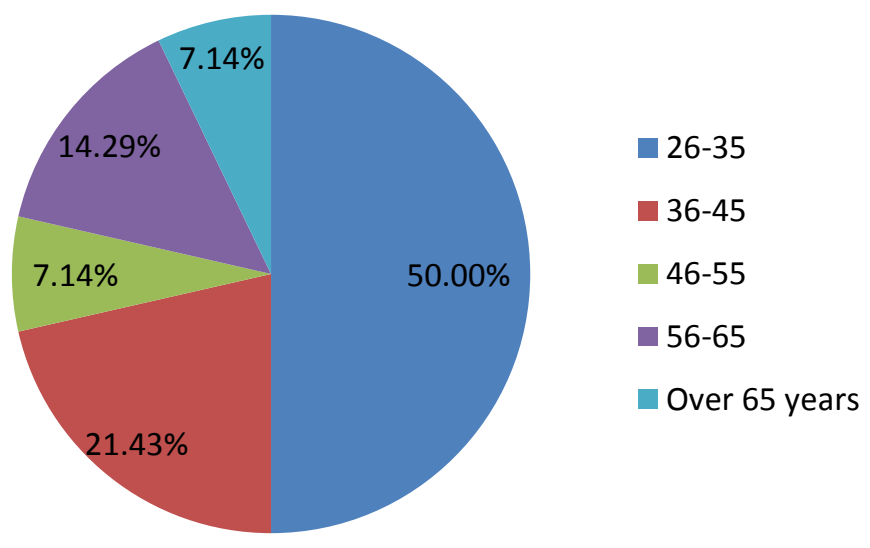

\section{Number of bedrooms?}

Many of the owner occupied homes have 3 bedrooms (64\%) and $22 \%$ have 2 bedrooms. 


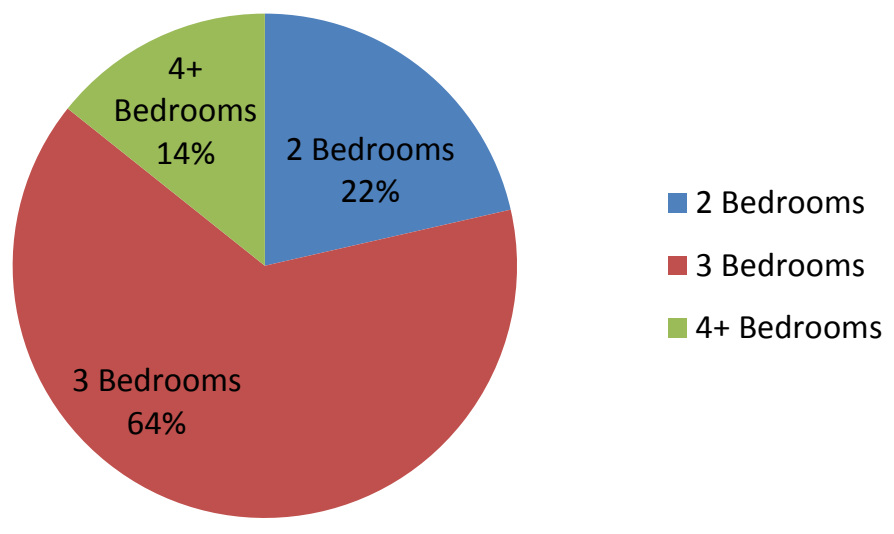

\section{Number of bathrooms?}

The majority at $57 \%$ have 2 bathrooms followed by 3 bathrooms.

Figure 43 Bathrooms.

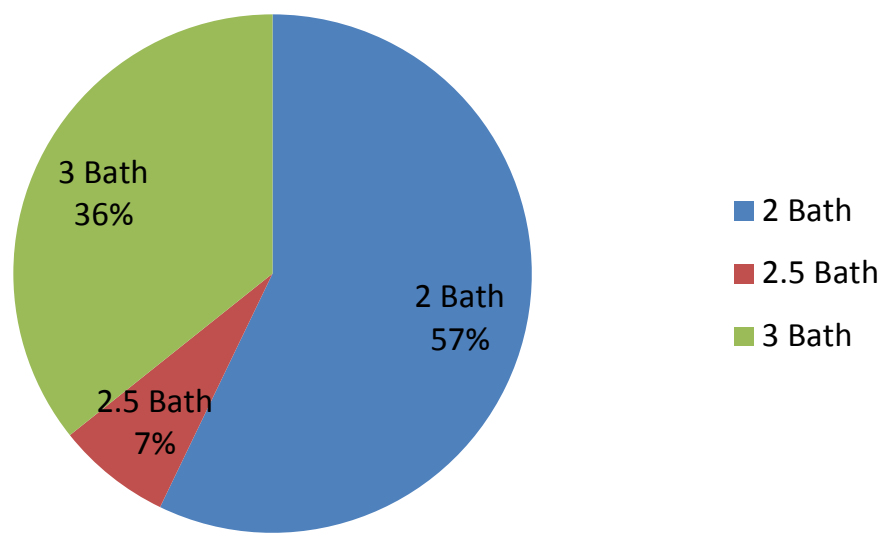

5. What type of home do you live in?

$64 \%$ of the owner occupied units were considered semi-detached dwellings.

$21 \%$ were detached SFR (single family residence) and $15 \%$ were multifamily. 
Figure 44 Type of Home.

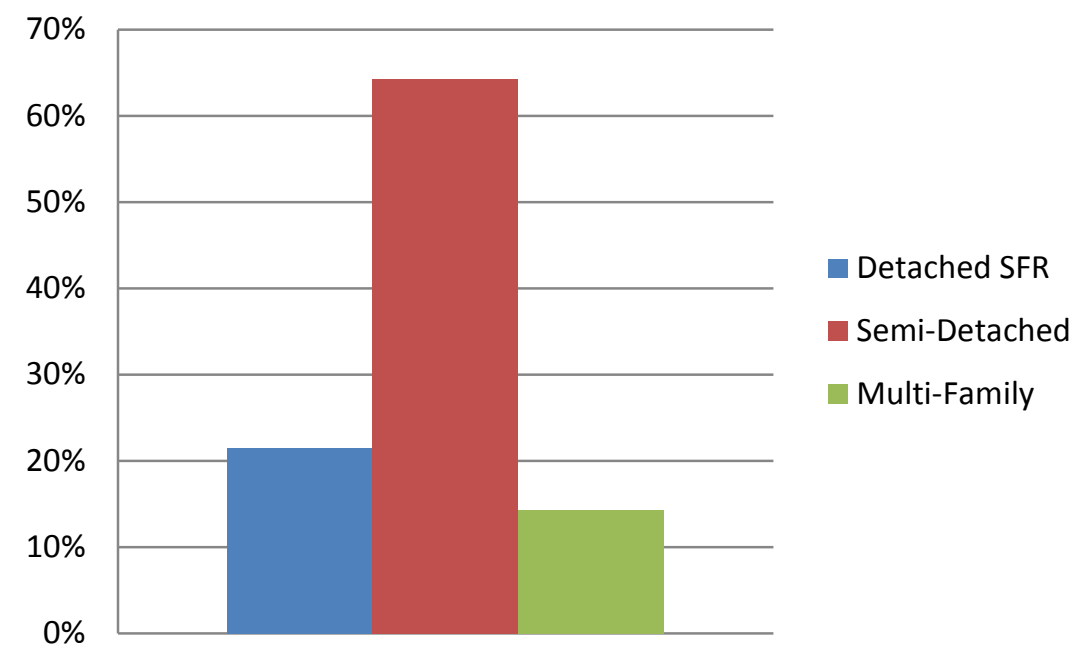

6. Which of the following parking facilities do you have?

A large number of respondents had garages (59\%) followed by $23 \%$ with street parking.

Figure 45 Parking Facilities.

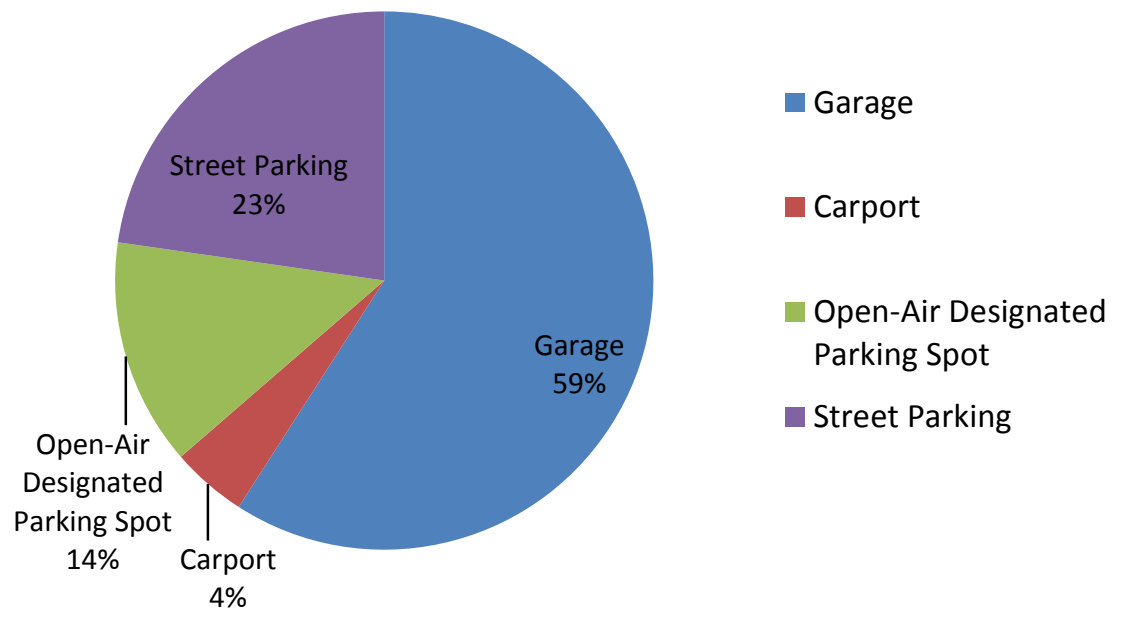

7. All in all, how would you rate the build quality and condition of your home?

At $61 \%$ the owners rated the build quality as excellent and $31 \%$ ranked their home as good quality. 
Figure 46 Build Quality and Condition of Home.

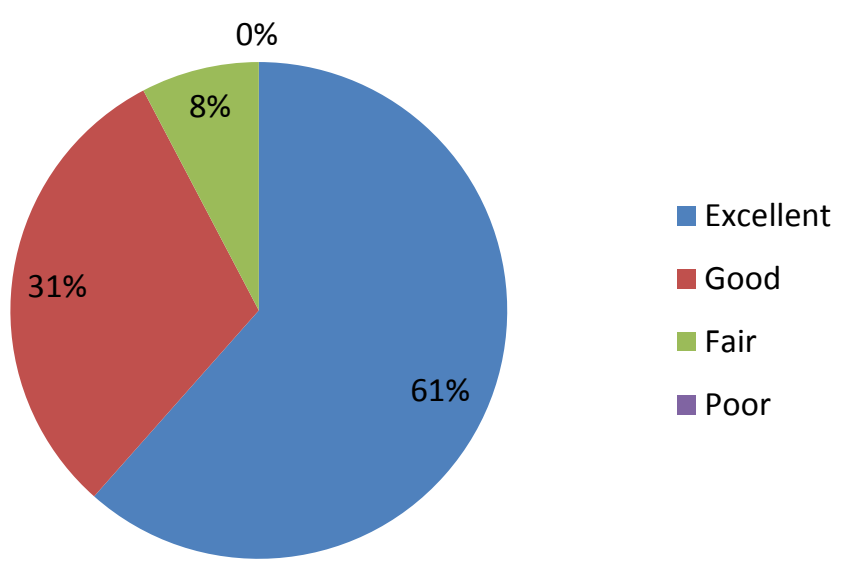

8. Do you have energy saving appliances?

Large portions $(80 \%)$ of the respondents do have energy saving appliances.

Figure 47 Energy Saving Appliances.

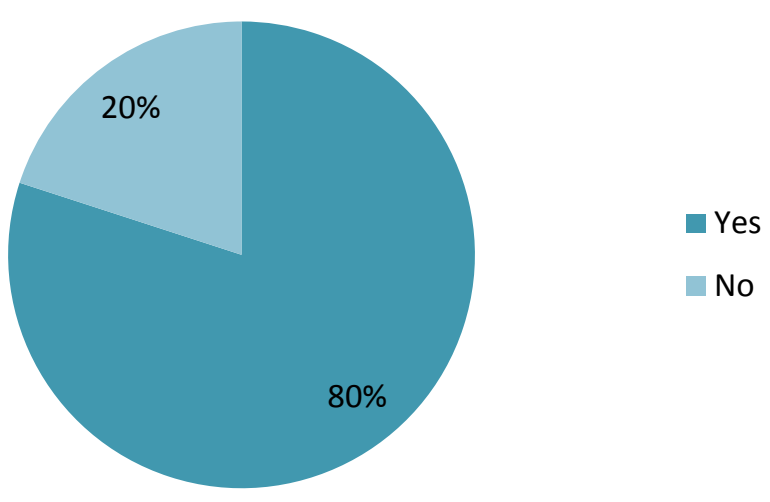

9. Which appliances are energy saving?

$27 \%$ of the owners have energy saving refrigerators followed by washers (21\%) and dishwashers (17\%). 


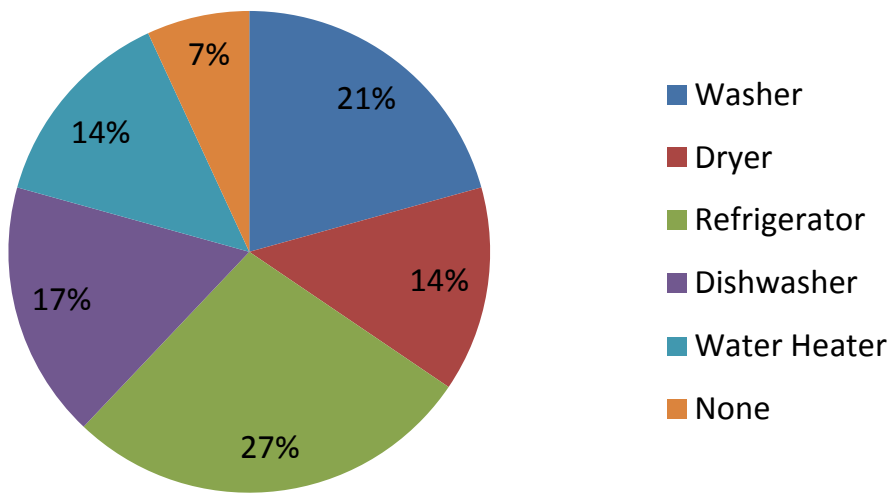

10. In an average work week, how many hours do you spend in the following types of spaces?

The majority of the hours are spent within the master bedroom and living room. The least used spaces, which average between 0 to 5 hours a week was the balcony/patio, garage followed by bathroom and common space. The kitchen seemed to be occupied between 21 to 25 hours a week.

Figure 49 Hours Spent in Spaces in the Home.

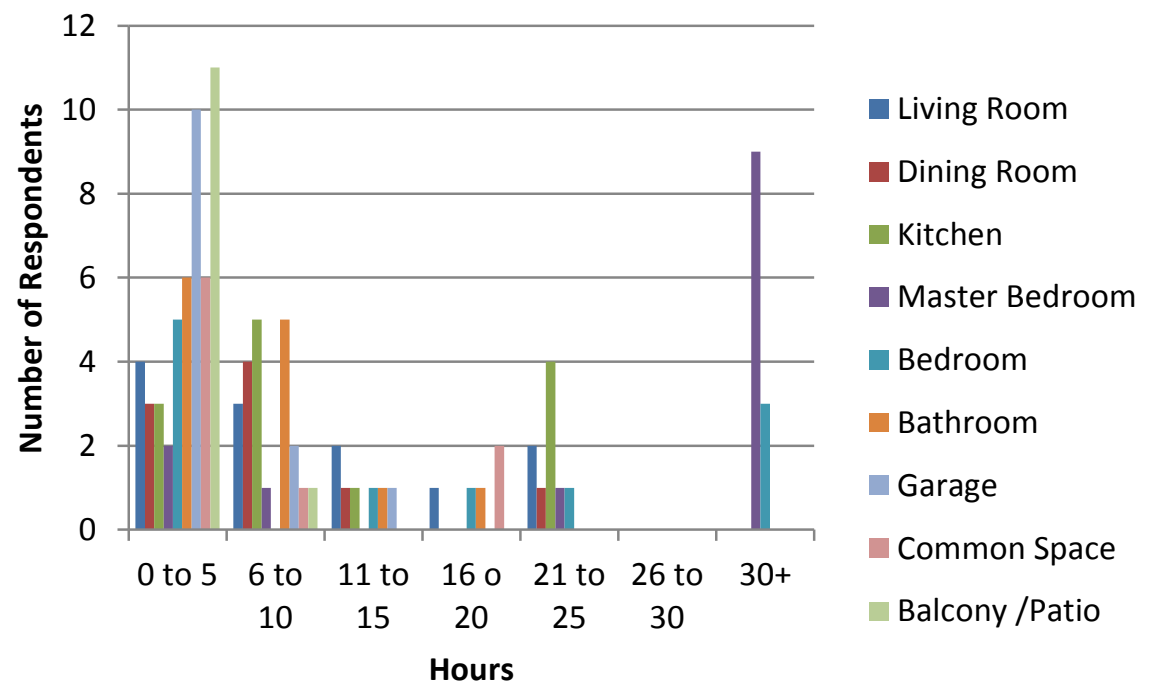




\subsubsection{SCALE RATING QUESTIONS}

11. Please rate the following on a scale from 1 (poor) to 5 (excellent) for the areas specified in the chart. (please write in 1,2,3,4 or 5 in the boxes)

The overall responses by the owners rated air quality for all spaces at a 4 or above. They seemed to be quite pleased with the existing air quality within the home. The values for ventilation ranged mostly from 3 to 5 for all spaces. However, many thought the ventilation in the bathroom was only seen as a 3 . The natural lighting category had a few more responses seen across the entire scale. A few rated the bathroom natural lighting closer to poor than excellent. However, the majority was pleased with the natural lighting within the master bedroom, living room, dining room and kitchen. Overall the heating and cooling category scored high marks for all spaces. All but one response thought the heating and cooling for all spaces were a 3 or higher. 
Figure $\mathbf{5 0}$ Rating of Air Quality.

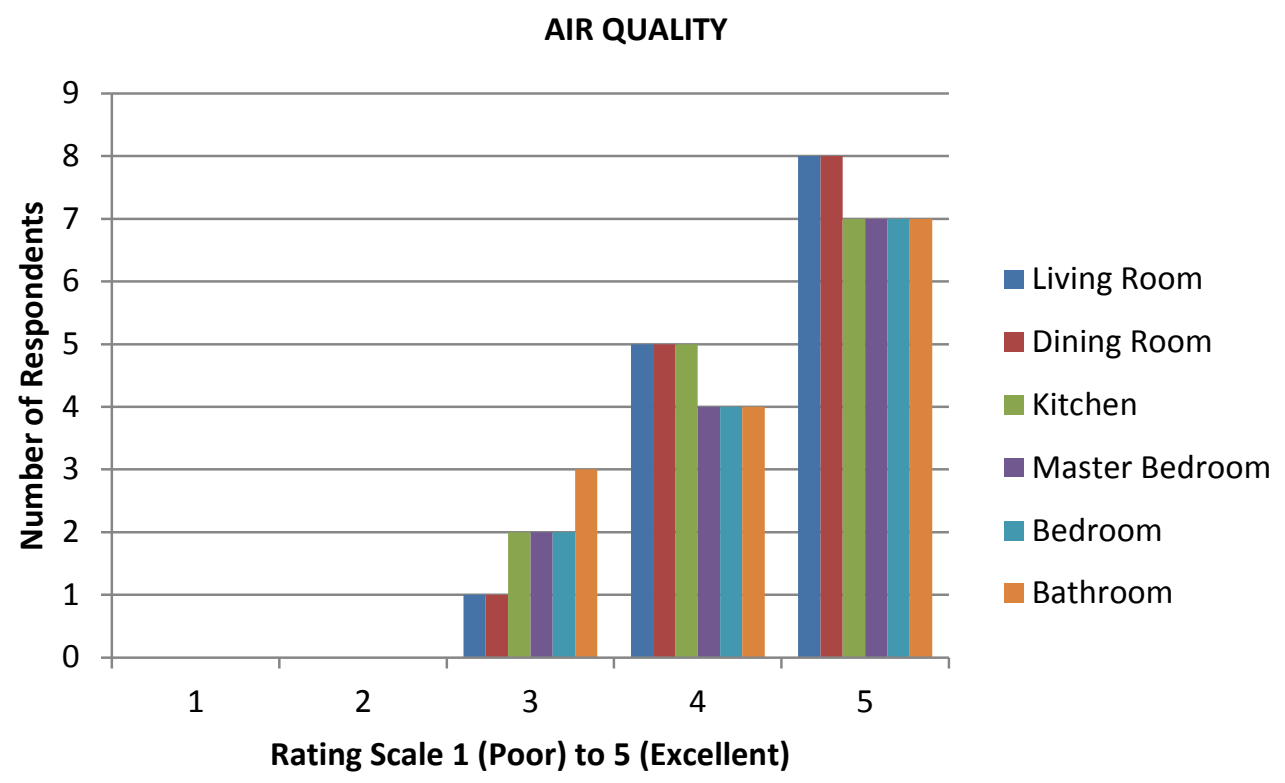

Figure 51 Rating of Ventilation.

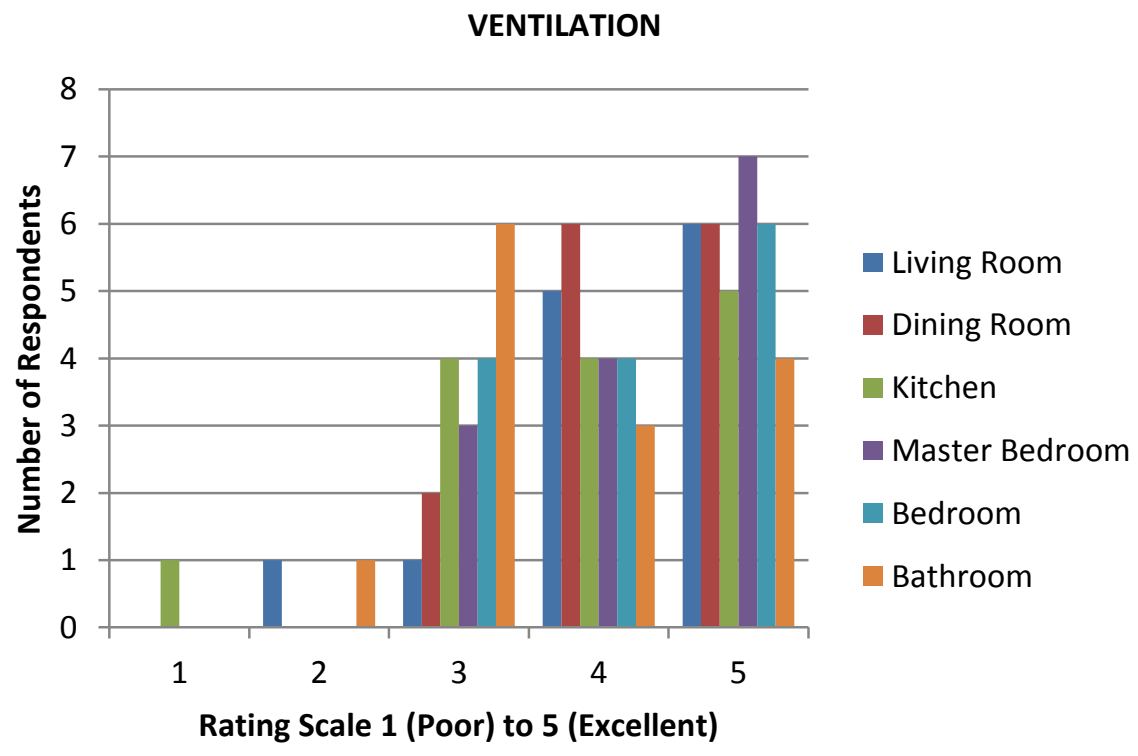




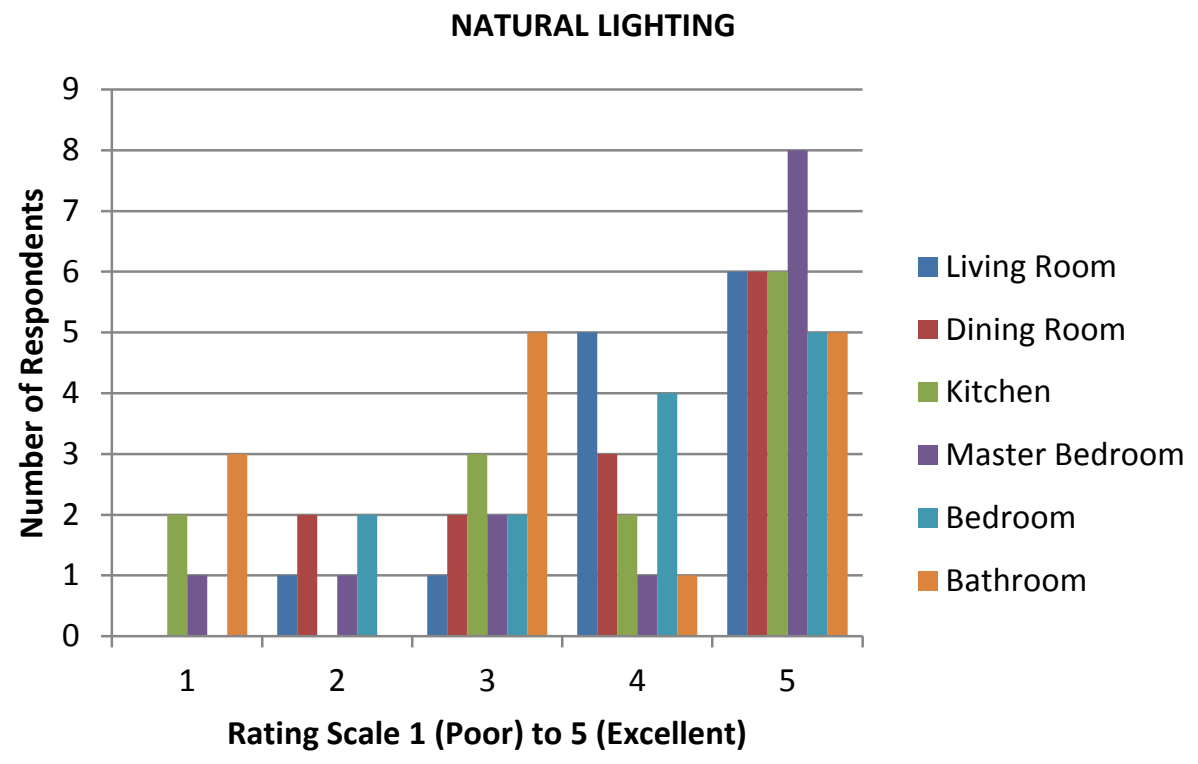

Figure 53 Rating of Heating/Cooling.

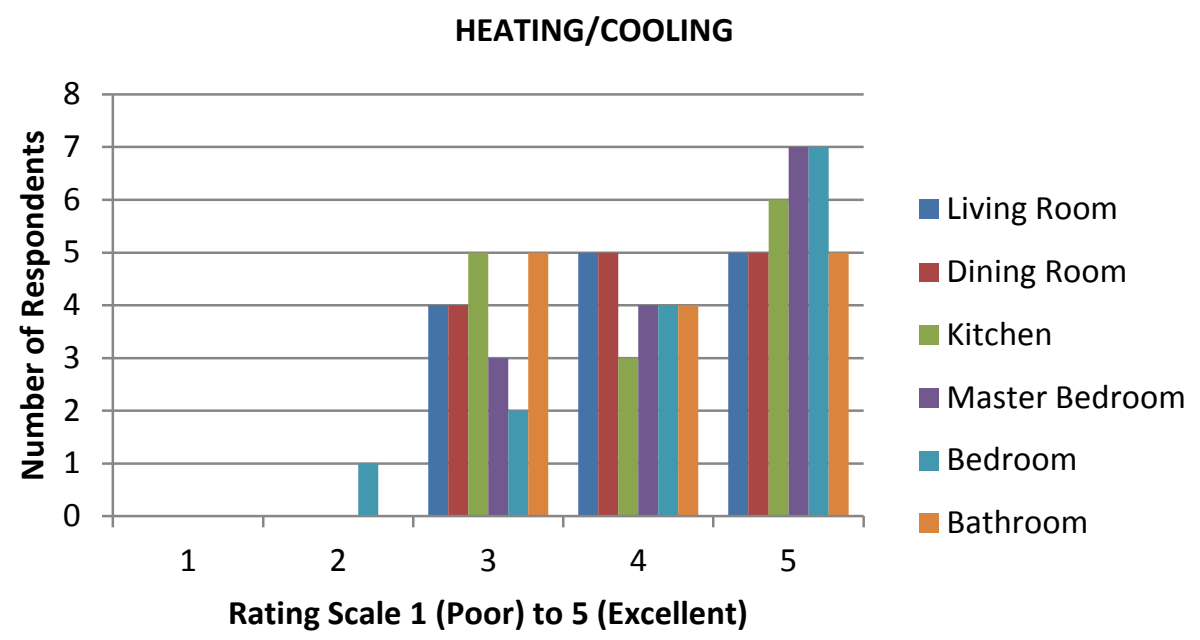

12. If you are currently working, where is your job located?

$53 \%$ of the owner's jobs, if working were located within San Luis

Obispo. The other locations which consisted of Avila Beach, 5 Cities 
area, San Barbara, Nipomo, Arroyo Grande and Morro Bay, were evenly disbursed between 6 to 7 percent of the remaining responses.

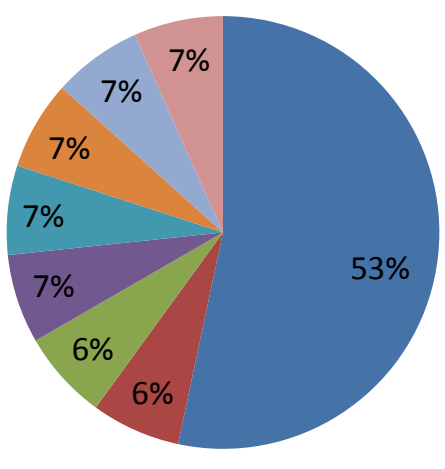

$$
\begin{aligned}
& \text { San Luis Obispo } \\
& \text { Avila Beach } \\
& 5 \text { Cities Area } \\
& - \text { Santa Barbara } \\
& - \text { Nipomo } \\
& \text { Arroyo Grande } \\
& \text { Morro Bay } \\
& \text { Retired }
\end{aligned}
$$

\section{How far do you travel to work?}

Since the majorities currently work in San Luis Obispo, many only traveled 0 to 5 miles to work (46\%). $23 \%$ travel 5 to 10 miles, whereas $16 \%$ travel 10 to 15 miles and $15 \%$ travel more than 15 miles to work.

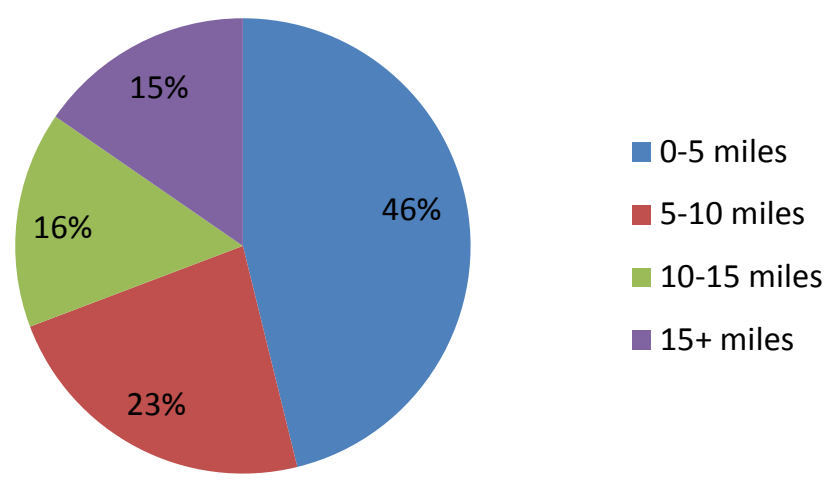

14. What is your primary mode of transportation?

A large $93 \%$ of the owners use the automobile as a primary mode of transportation. Only 7\% use their bike. 


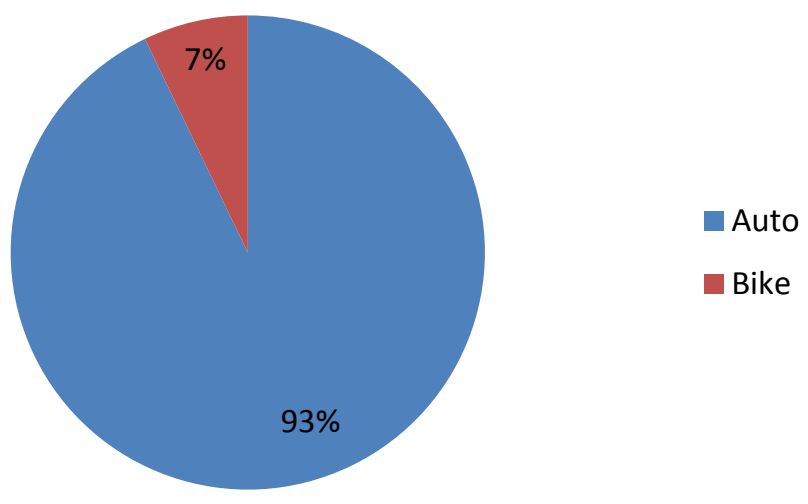

15. What is your secondary mode of transportation?

Many do not use a secondary mode of transportation (41\%). As far as walking, taking the bus and biking, only $17 \%$ said they use these forms of transportation as a secondary mode.

Figure 57 Secondary Mode of Transportation.

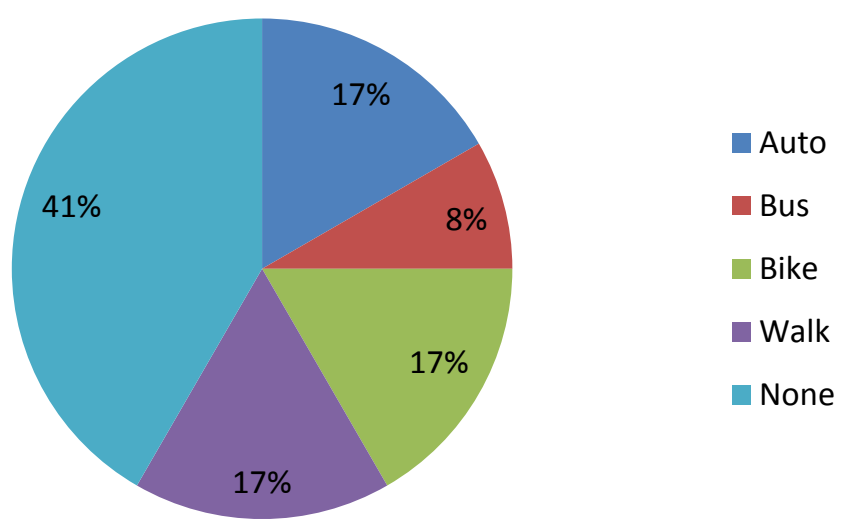

16. Indicate distances needed to travel to surrounding services.

The facilities found mostly within $1 / 4$ mile of the home were: parks, bus stops, and shopping and bike paths. This assumes these four facilities 
are within a 20 minute walking distance from someone's home. The remainder amenities would require further walking distances and/or the use of a vehicle, bus or bike in order to get to them. The furthest amenity was medical facilities.

Figure 58 Parameters to Local Amenities.

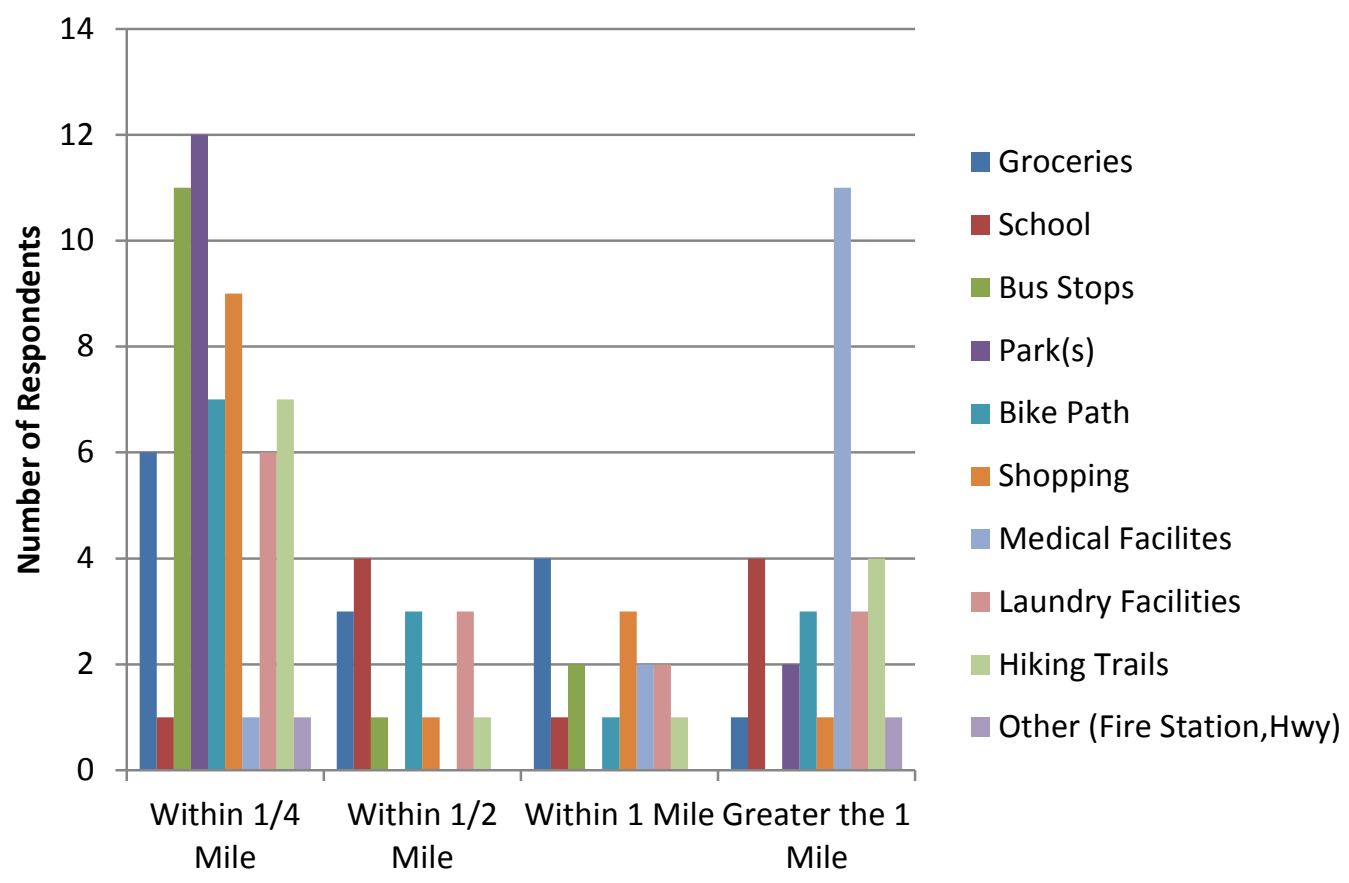

\subsubsection{OPEN-ENDED QUESTIONS}

17. If you could change 3 things about your home what would those be?

The top responses included wanting larger yards and/or patios and balconies, detached walls from neighbors, and better material finishes within the home. (Appendix G-3)

18. List the features of your home you are most satisfied with?

The top responses included location, the open floor plan and size of master bedroom and kitchen. Many were pleased with the newer 
constructed homes and the freshness of the materials and air quality. (Appendix G-3)

The owner responses were similar to the overall responses. However, the locations of jobs within the City were much less at $53 \%$ compared to the overall responses at $84.4 \%$. More owners were traveling greater than 5 miles to their jobs, $23 \%$ were traveling $5-10$ miles where the overall analysis showed $16.2 \%$. There was only a small difference in local services within a $1 / 4$ mile radius, the owners stated parks, bus stops, bike lanes and shopping were all within a 20 minute walking distance.

\subsection{RENTER RESPONSE ANALYSIS}

\subsubsection{MULTIPLE CHOICE QUESTIONS}

1. Sex:

The majority of the renter respondents were males at $53 \%$ followed by $47 \%$ females.

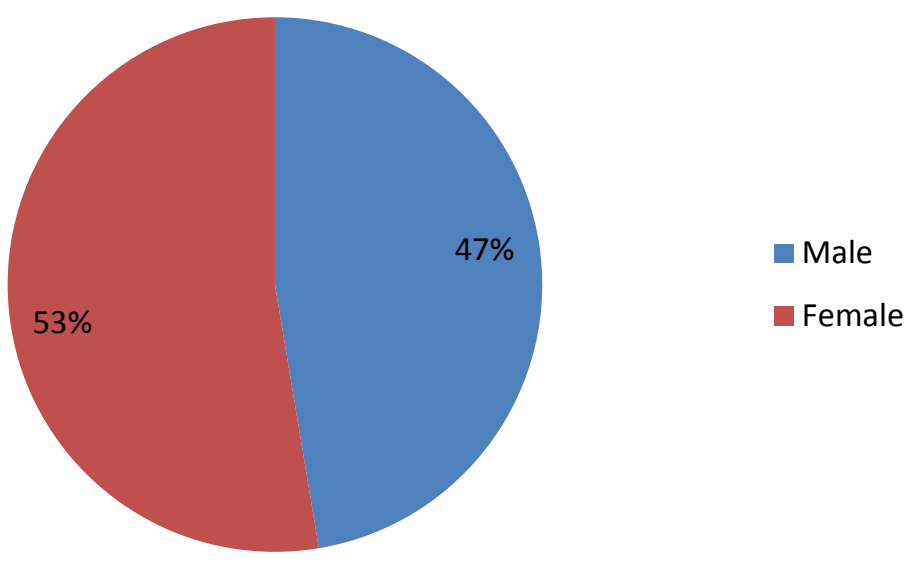


2. Age Group:

$52 \%$ of the renter responses fell into the age group of 65 years or older. This was mostly due to the majority of the senior housing units are rentals and were included within this count. This was followed by $26-35$ years $(17 \%)$ and $56-65$ years (17\%).

Figure 60 Age Group.

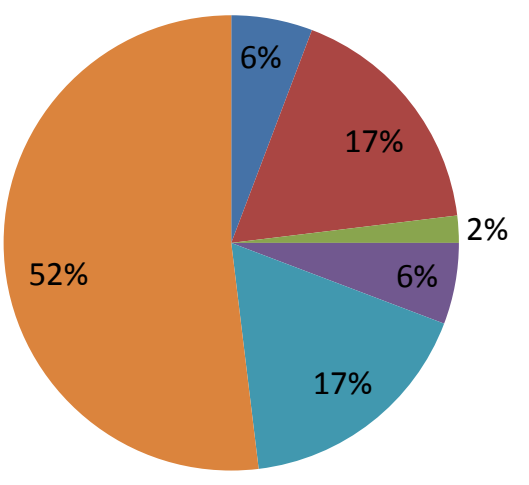

$$
\begin{aligned}
& 18-25 \\
& -26-35 \\
& 36-45 \\
& 46-55 \\
& 56-65 \\
& \text { Over } 65
\end{aligned}
$$

\section{Number of bedrooms?}

A large number of the renter occupied homes are 1 bedrooms (66\%) and $21 \%$ have studios.

\section{Figure 61 Bedrooms.}

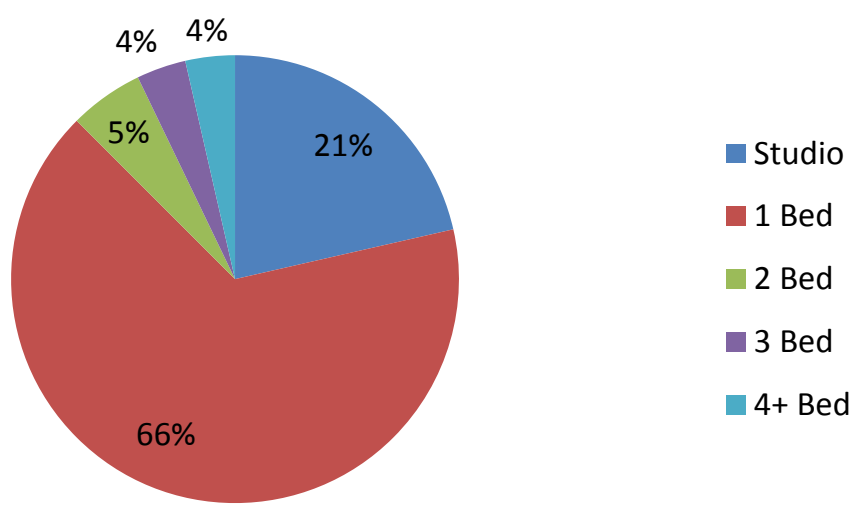


4. Number of bathrooms?

The majority at $87 \%$ have 1 bathrooms followed by $3+$ bathrooms $(9 \%)$.

Figure 62 Bathrooms.

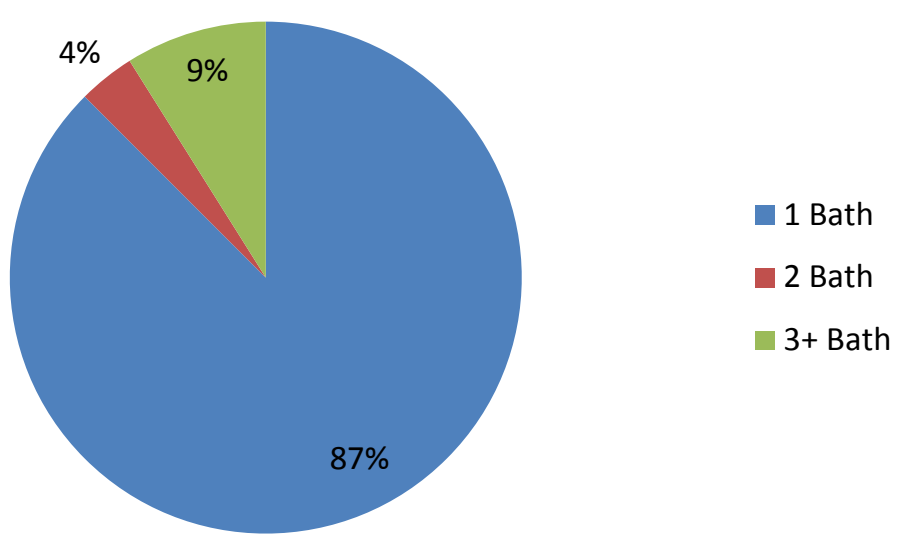

5. What type of home do you live in?

$87 \%$ of the renter occupied units were considered multi-family dwellings. $9 \%$ were semi-detached and $3 \%$ were detached SFR (Single Family Residence). 
Figure 63 Type of Home.

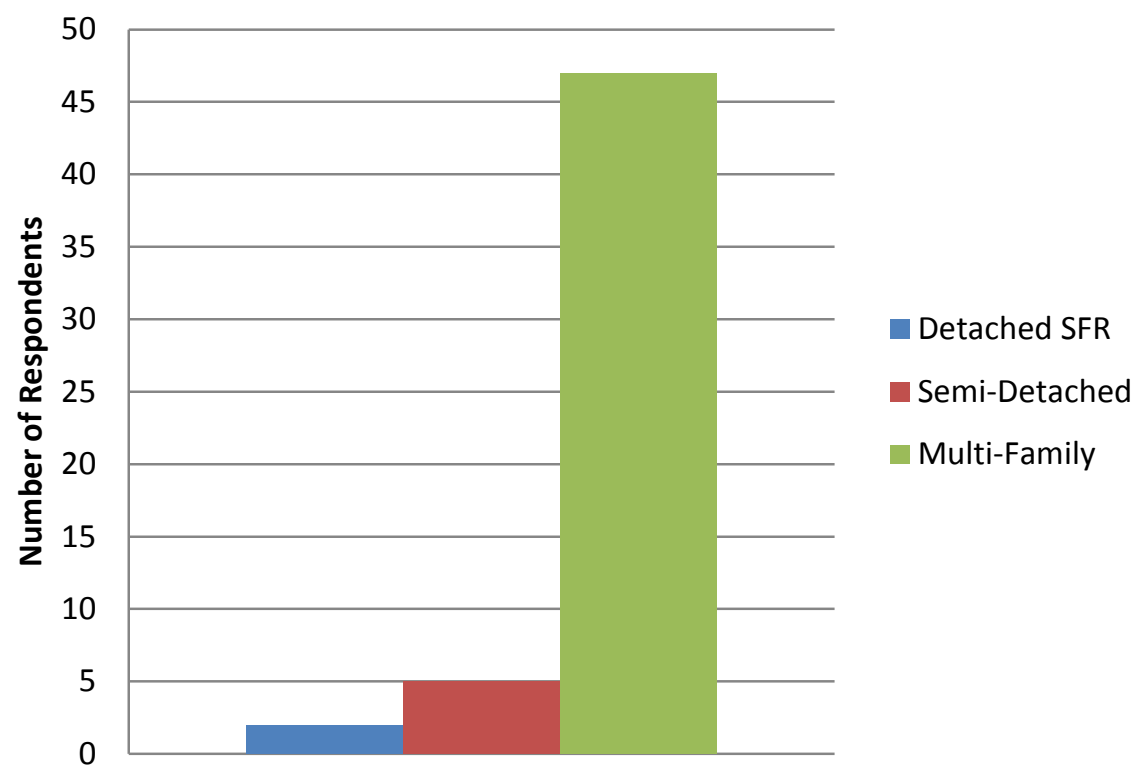

6. Which of the following parking facilities do you have?

A large number of respondents had open-air designated parking spots (44\%) followed by $30 \%$ with street parking.

Figure 64 Parking Facilities.

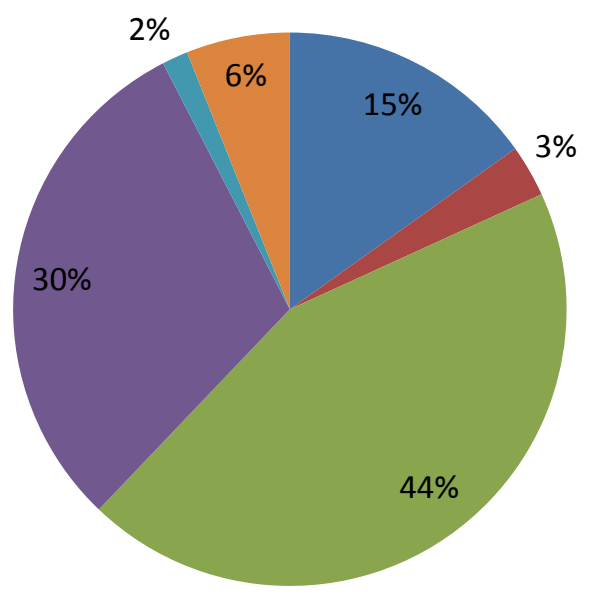

- Garage

Carport

- Open-Air Designatied Parking Spot

- Street Parking

- Shared Parking

No Parking

7. All in all, how would you rate the build quality and condition of your home? 
At $46 \%$ the renters rated the build quality as excellent and $36 \%$ ranked their home as good quality followed by $18 \%$ thought it was poor quality. Figure 65 Build Quality and Condition.

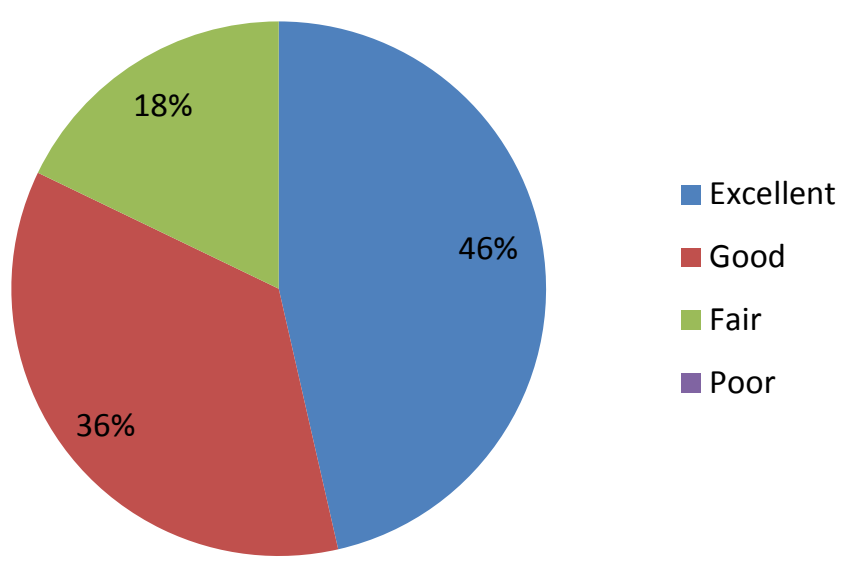

8. Do you have energy saving appliances?

$53 \%$ of the respondents do have energy saving appliances, where $40 \%$ did not.

Figure 66 Energy Saving Appliances.

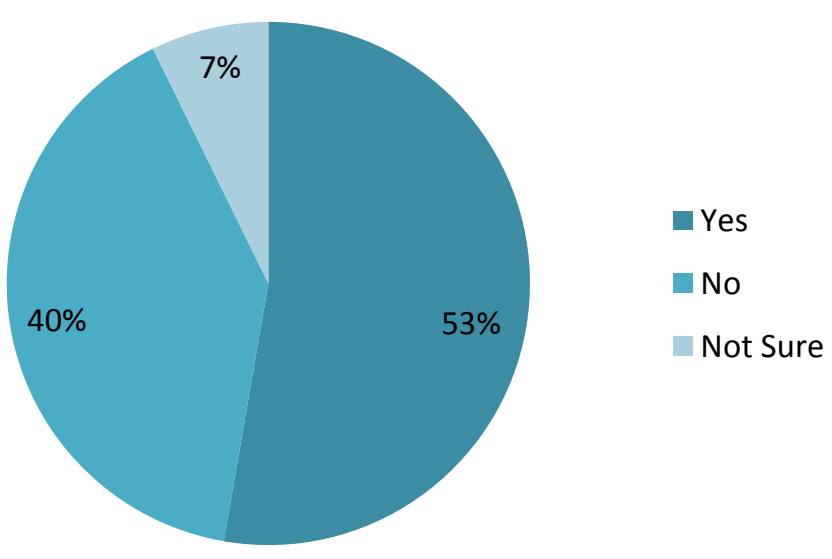

9. Which appliances are energy saving? 
$28 \%$ of the renters have energy saving refrigerators followed by washers $15 \%)$ and dryers (12\%).

Figure 67 Types of Energy Saving Appliances.

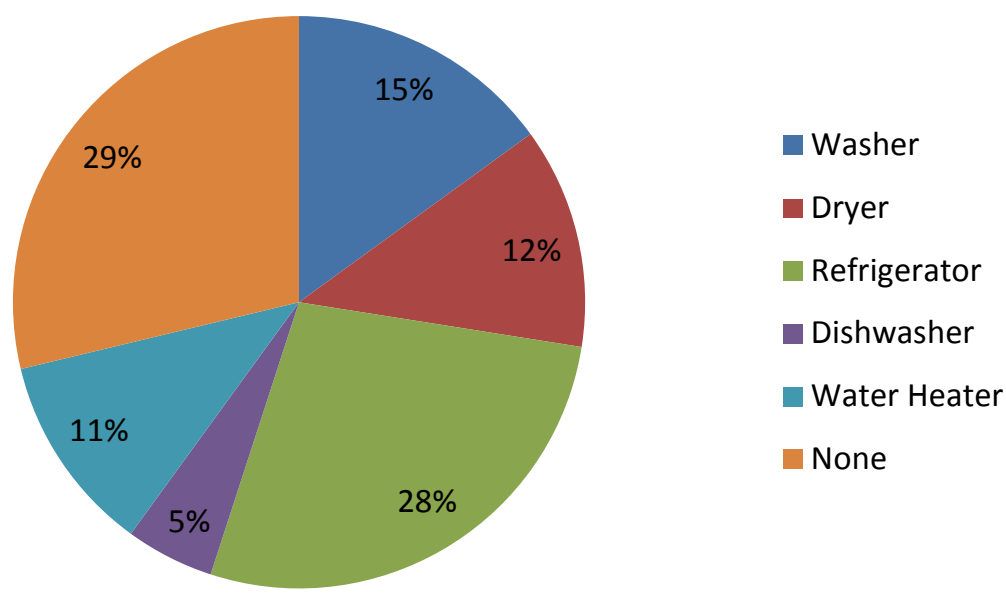

10. In an average work week, how many hours do you spend in the following types of spaces?

The majority of the hours are spent within the master bedroom and living room. The least used spaces, which average between 0 to 5 hours a week was the balcony/patio, common space, bathroom and kitchen. 
Figure 68 Hours Spent in Spaces in the Home.

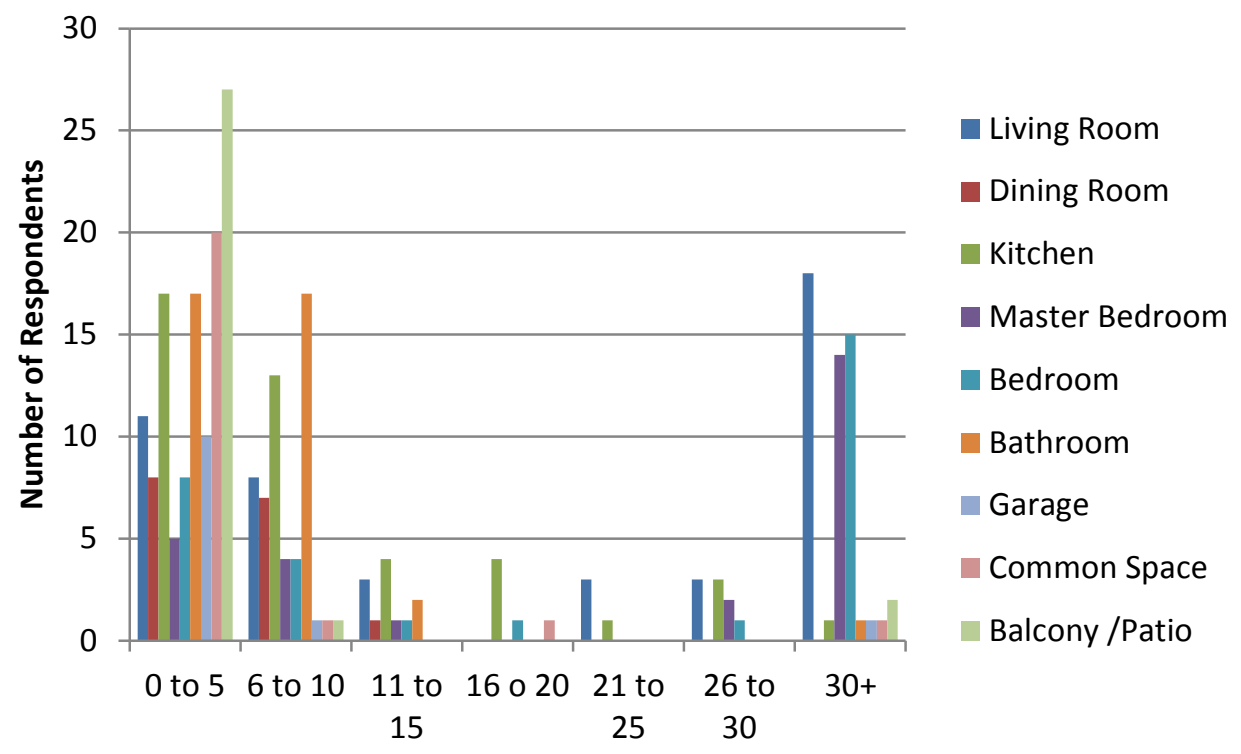

\subsubsection{SCALE RATING QUESTIONS}

11. Please rate the following on a scale from 1 (poor) to 5 (excellent) for the areas specified in the chart. (please write in 1,2,3,4 or 5 in the boxes)

The overall responses by the renters rated air quality for all spaces at a 4 or above except for a few who rated the bathroom air quality at poor. They seemed to be quite pleased with the existing air quality within the home. The values for ventilation ranged mostly from 3 to 5 for all spaces. However, many thought the ventilation in the bathroom; kitchen and living rooms were only seen as a 1 to 3 . The natural lighting category ranked poorly as far as the kitchen and bathroom. The living rooms and bedrooms seemed to be satisfactory or above had a few more responses seen across the entire scale. Overall the heating and cooling category scored high marks for all spaces. 
However, a few responses thought the heating and cooling for the living room, kitchen and bathrooms were closer to the poor side of the scale.

Figure 69 Rating of Air Quality.

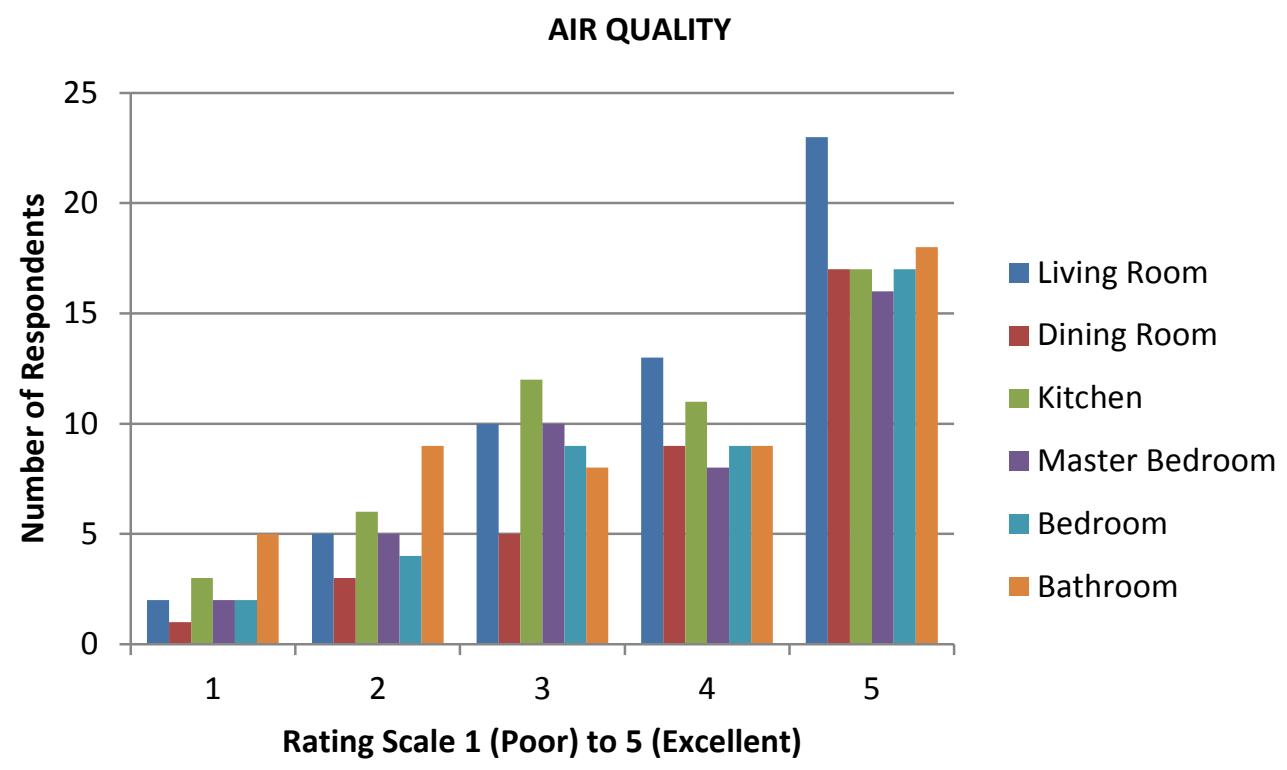

Figure 70 Rating of Ventilation.

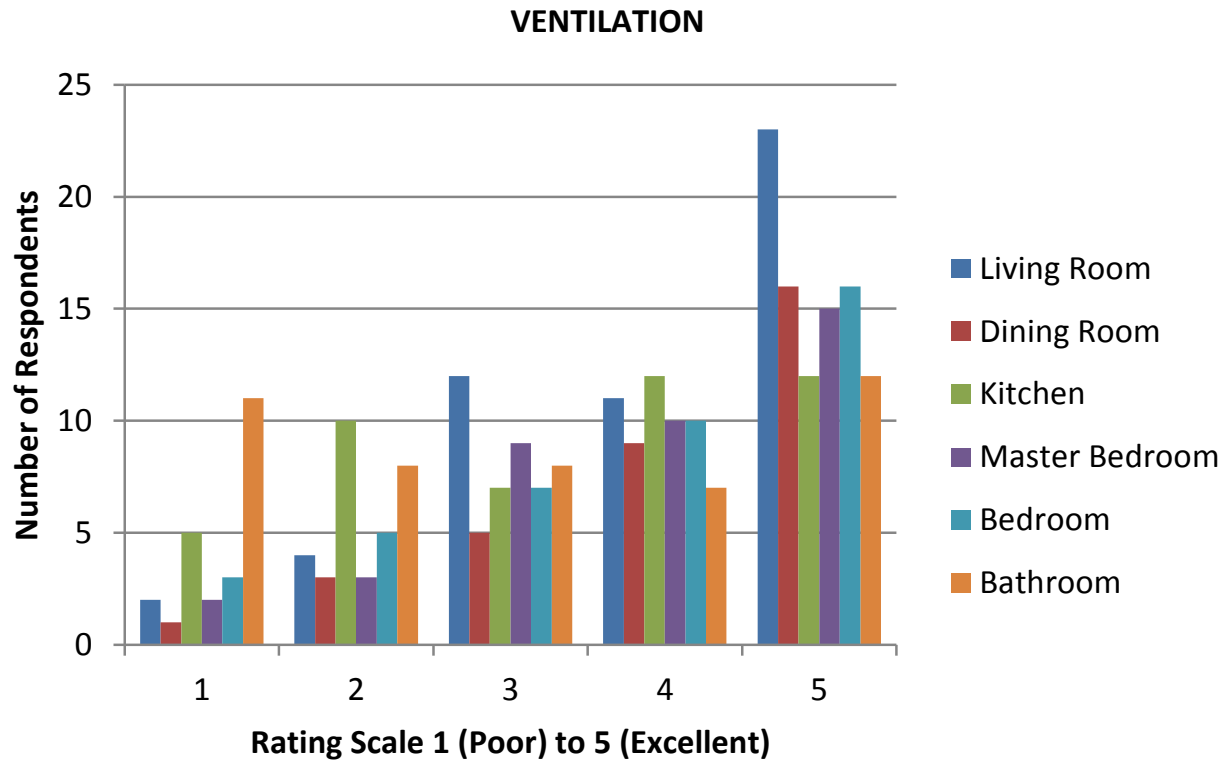


Figure 71 Rating of Natural Lighting.

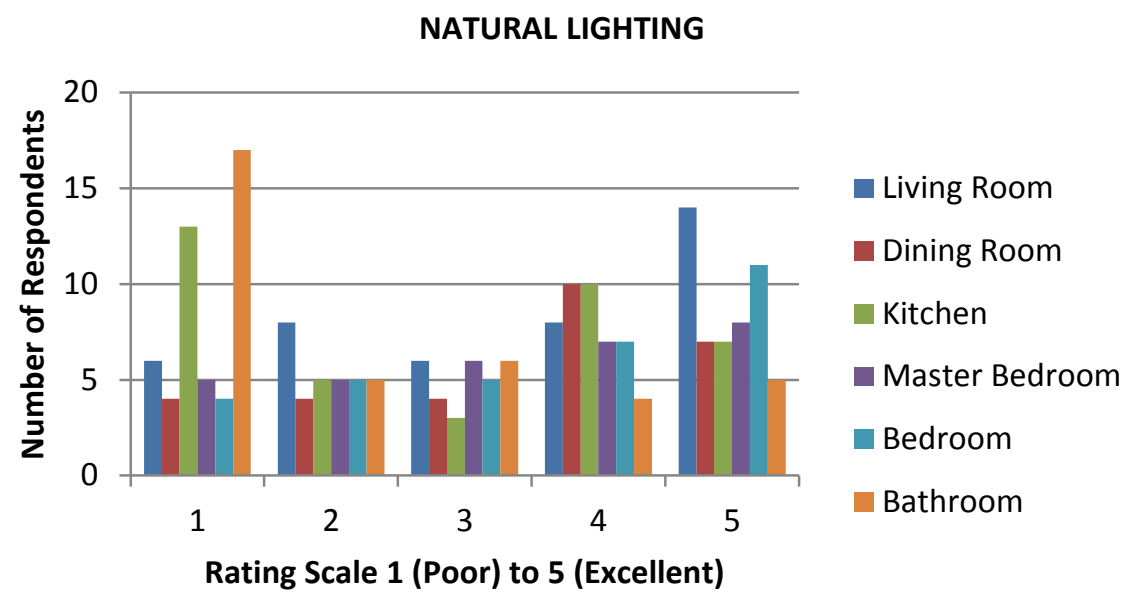

Figure 72 Rating of Heating/Cooling.

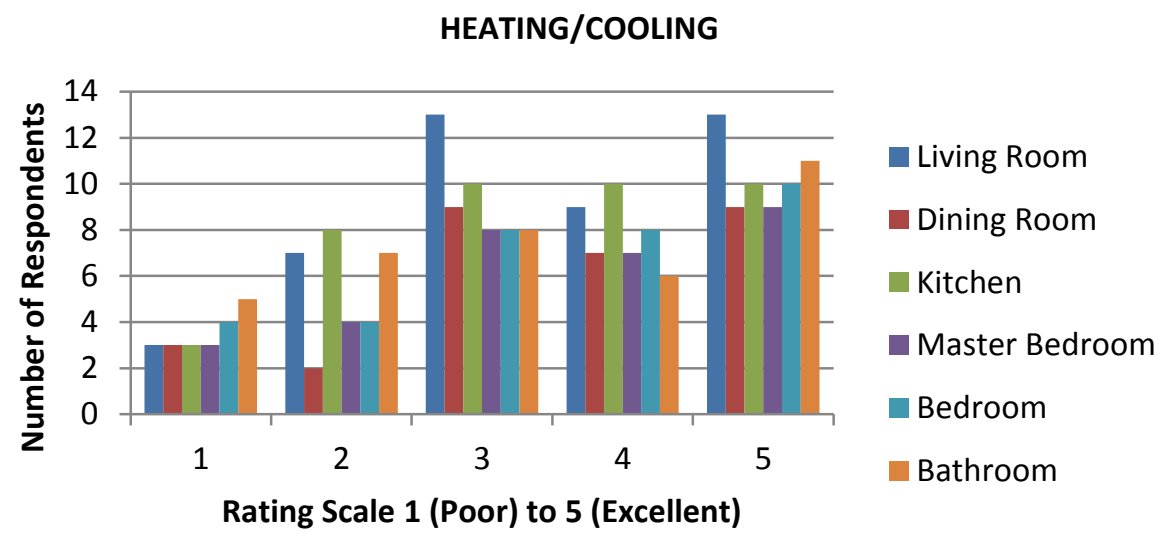

12. If you are currently working, where is your job located?

$39 \%$ of the renter's jobs, if working were located within San Luis

Obispo. The other locations which consisted of Avila Beach, 5 Cities

area, San Barbara, Nipomo, Arroyo Grande and Morro Bay, were

evenly disbursed between $2 \%$ to $7 \%$, where $24 \%$ were not working and $26 \%$ were retired. 


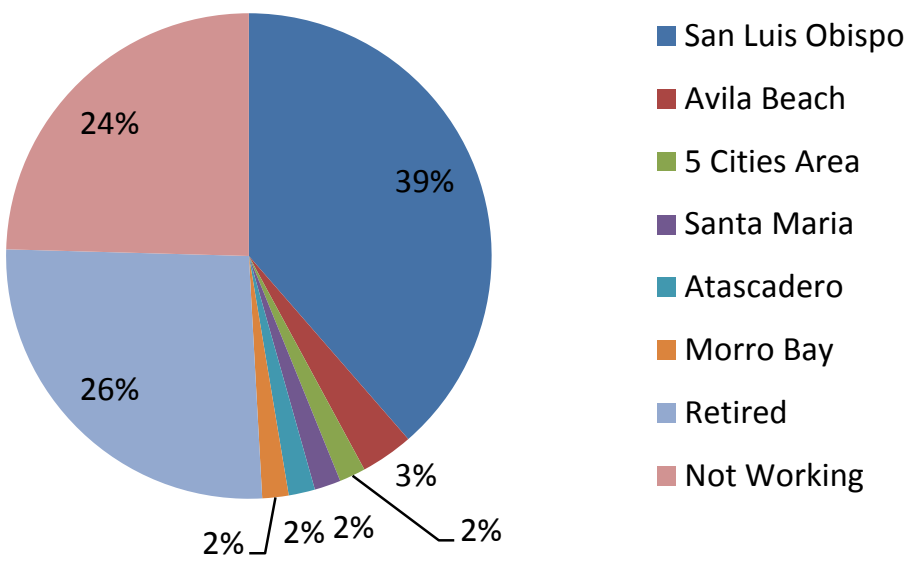

13. How far do you travel to work?

Since many renters were not working or retired, this question did not pertain to them. However those currently working (37\%) only travel 0 to 5 miles to work.

Figure 74 Miles Traveled to Work.

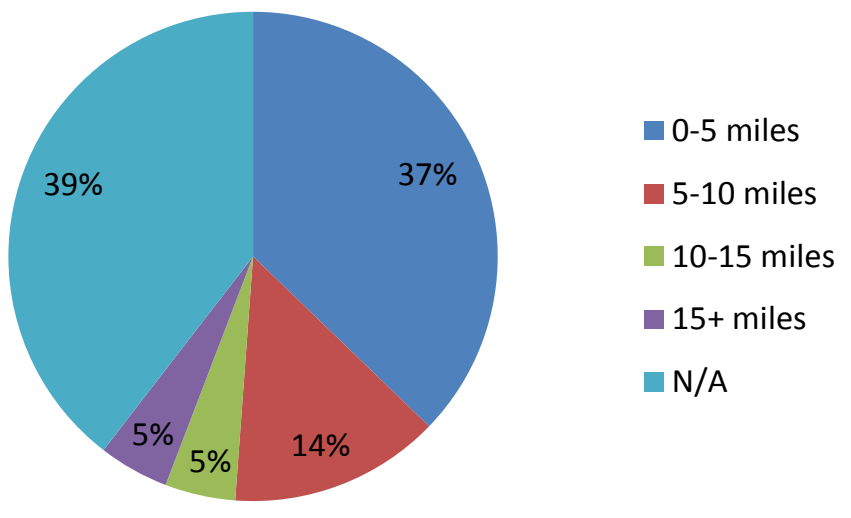

14. What is your primary mode of transportation?

A large $72 \%$ of the renters use the automobile as a primary mode of transportation. Only $11 \%$ use the bus, $7 \%$ bike and $4 \%$ either walk or carpool/rideshare. 


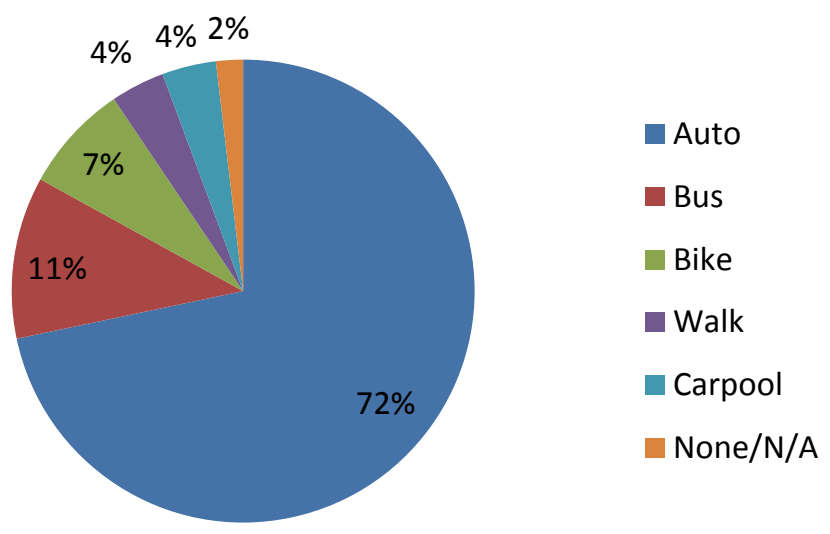

15. What is your secondary mode of transportation?
A large $40 \%$ choose walking as their second mode of transportation, $15 \%$ bike and $12 \%$ take the bus. Many do not use a secondary mode of transportation (40\%).

Figure 76 Secondary Mode of Transportation.

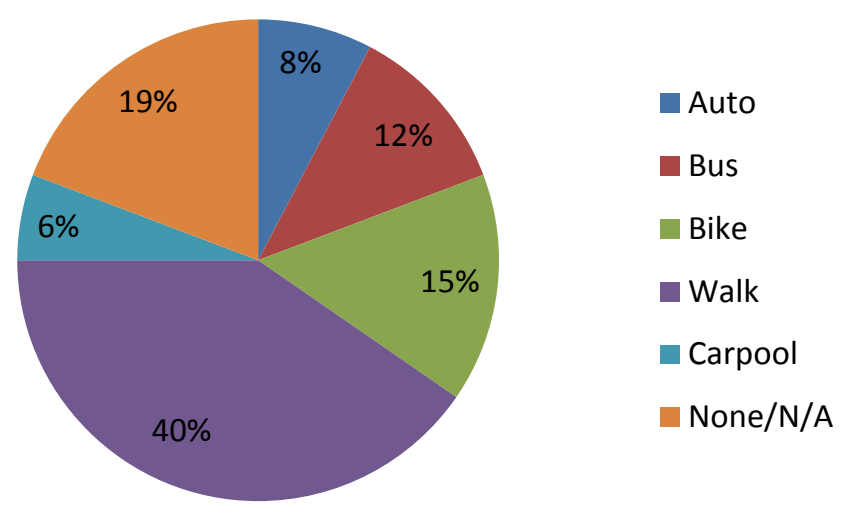

16. Indicate distances needed to travel to surrounding services.

The facilities found mostly within $1 / 4$ mile of the home were: laundry facilities (most were on-site), bus stops, and parks. This assumes these four facilities are within a 20 minute walking distance from 
someone's home. The remainder amenities would require further walking distances and/or the use of a vehicle, bus or bike in order to get to them. The furthest amenity was medical facilities.

Figure 77 Parameters to Local Amenities.

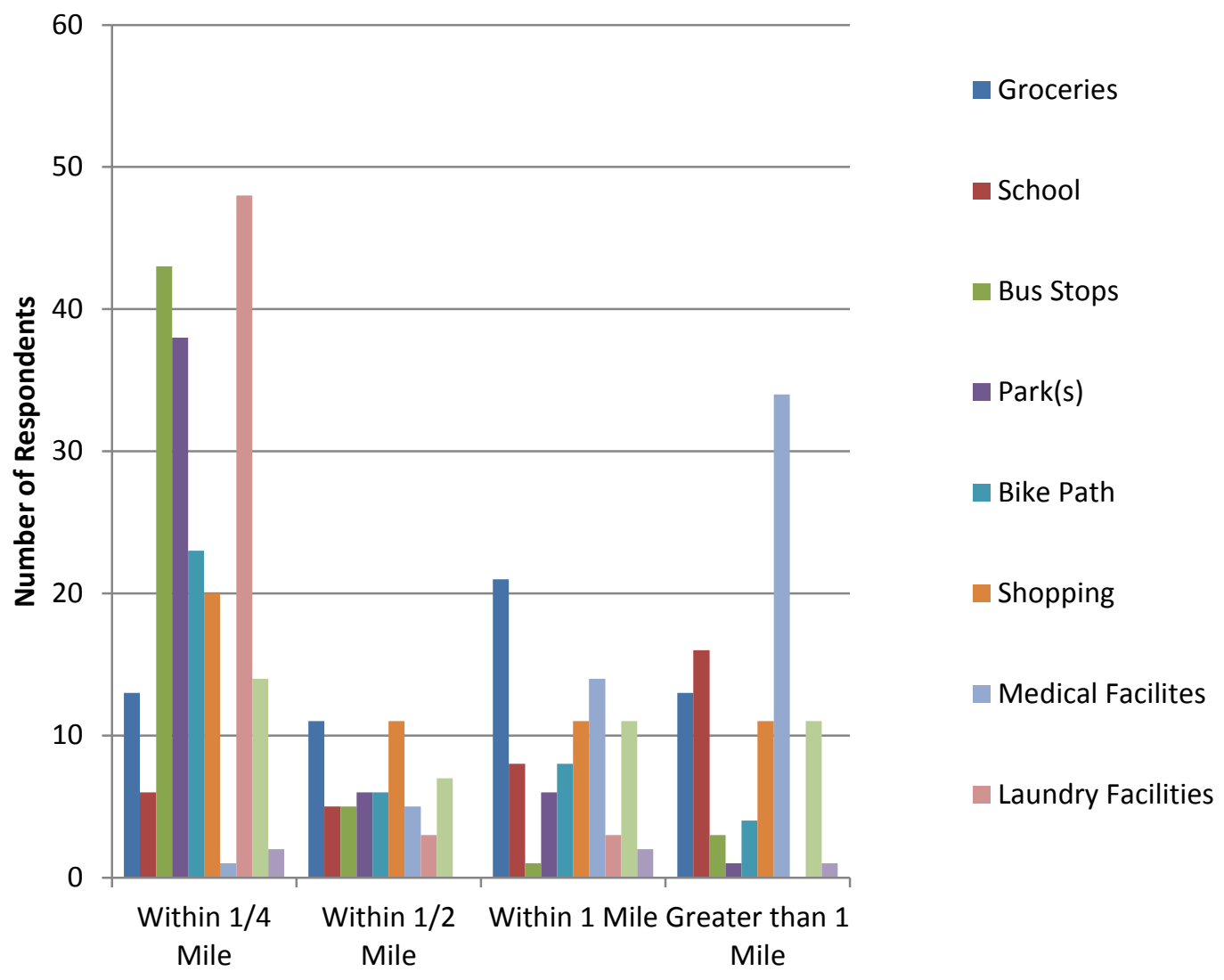

\subsubsection{OPEN-ENDED QUESTIONS}

17. If you could change 3 things about your home what would those be?

The top responses included wanting more parking, better natural

lighting, larger spaces within the home, better heating and less noise

from the surrounding area. (Appendix G-4)

18. List the features of your home you are most satisfied with? 
The top responses included location, on-site laundry, neighbors, cost of rent, and the views from their homes, maintenance and cleanliness of the units. (Appendix G-4)

The renters' responses showed a difference in the job situation to that of owners and overall analysis. A high $24 \%$ were not working; however the renter analysis included the senior responses since they were all renters as well. A low $39 \%$ were working in the City and $26 \%$ were retired. This analysis showed a decrease in the percentages for miles traveled to work. Only 37\% were traveling 0-5 miles and 39\% was deemed not applicable. Also as seen in the other analysis, $30 \%$ or higher stated laundry facilities, parks, bus stops and bike lanes were all located within a 20 minutes walking distance from their home.

The findings of the survey had a few surprises. Some surprises included the number of responses were much more than anticipated; where large amounts were from the affordable senior units located within the City. According to the responses, the senior units seem to be in much poorer shape than the other affordable units within San Luis Obispo. Further investigation into why this is, will be conducted at a later time. The outcome to the POE survey shows great promise as a task that could be completed by the City on an annual basis. These results can help shape the future for affordable housing no matter if it is owner occupied, renter occupied or housing for seniors. The design of a home should fit and accommodate the individual needs of the occupants, where at the same time create good 
design. The overall responses were positive and many of the participants enjoyed conducting the survey. The information gathered from these surveys will be translated into a GIS map showing possible future sites for affordable housing based on the information gathered from the surveys. This investigation will be discussed in the next section.

\subsection{BEST LOCATIONS FOR AFFORDABLE HOUSING IN SAN LUIS}

\section{OBISPO}

After collecting data from the assessment survey, many participates expressed one of the best attributes of their affordable housing units was the location. With this information, a GIS map was generated to show those that were pleased with their location. In addition to this information, a $1 / 4$ mile radius was generated in order to see if these "best location" units were properly located regarding access to local amenities and multi-modal transportation options. A third map was compiled showing possible future sites for affordable housing. This information was based upon the existing "best location" sites and their evaluation of the amenities. If the "best location" sites were not properly located to amenities and transportation, an adjustment was made. Figure 78 shows the existing location of the inclusionary housing units. These units were those units surveyed. Those units who expressed that their location was one of the features they were most satisfied with were generated into a best locations map, which showed three quadrants or areas in San Luis Obispo (Figure 79 and 80). The three areas include areas in the 
LOVR and Madonna road, area 2 is in the downtown core and area 3 is in the Orcutt and Johnson Ave area.

Figure 78 Existing Inclusionary Units.

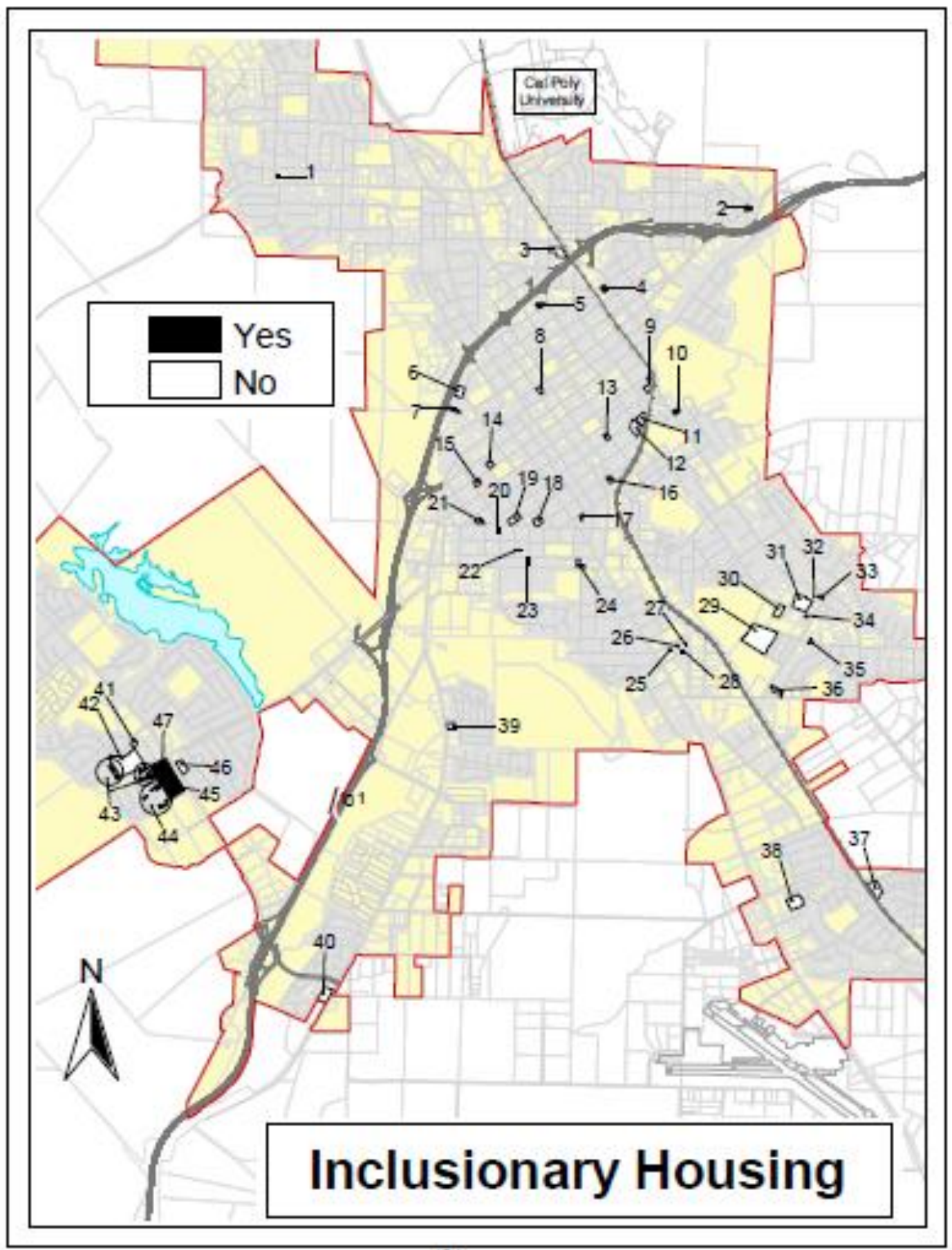

Source: 2010 Housing Element, City of San Luis Obispo 
Figure 79 Best Locations based on survey results

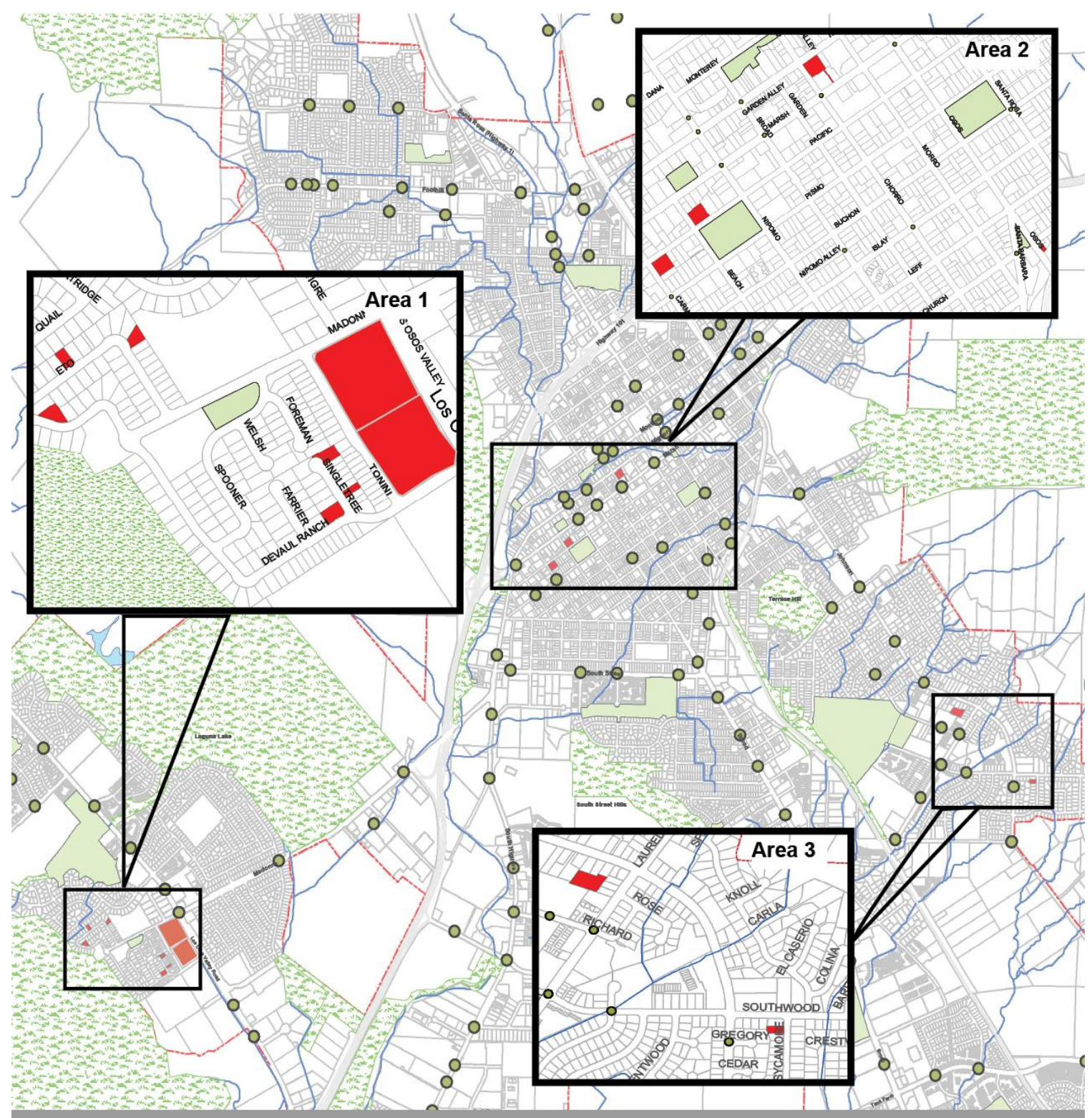

Affordable Housing "Best Locations"
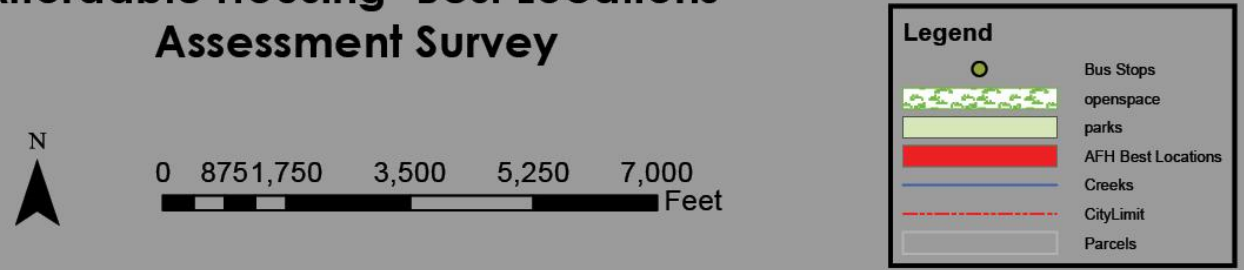
Figure 80 Best Locations based on survey results with $1 / 4$ mile radius

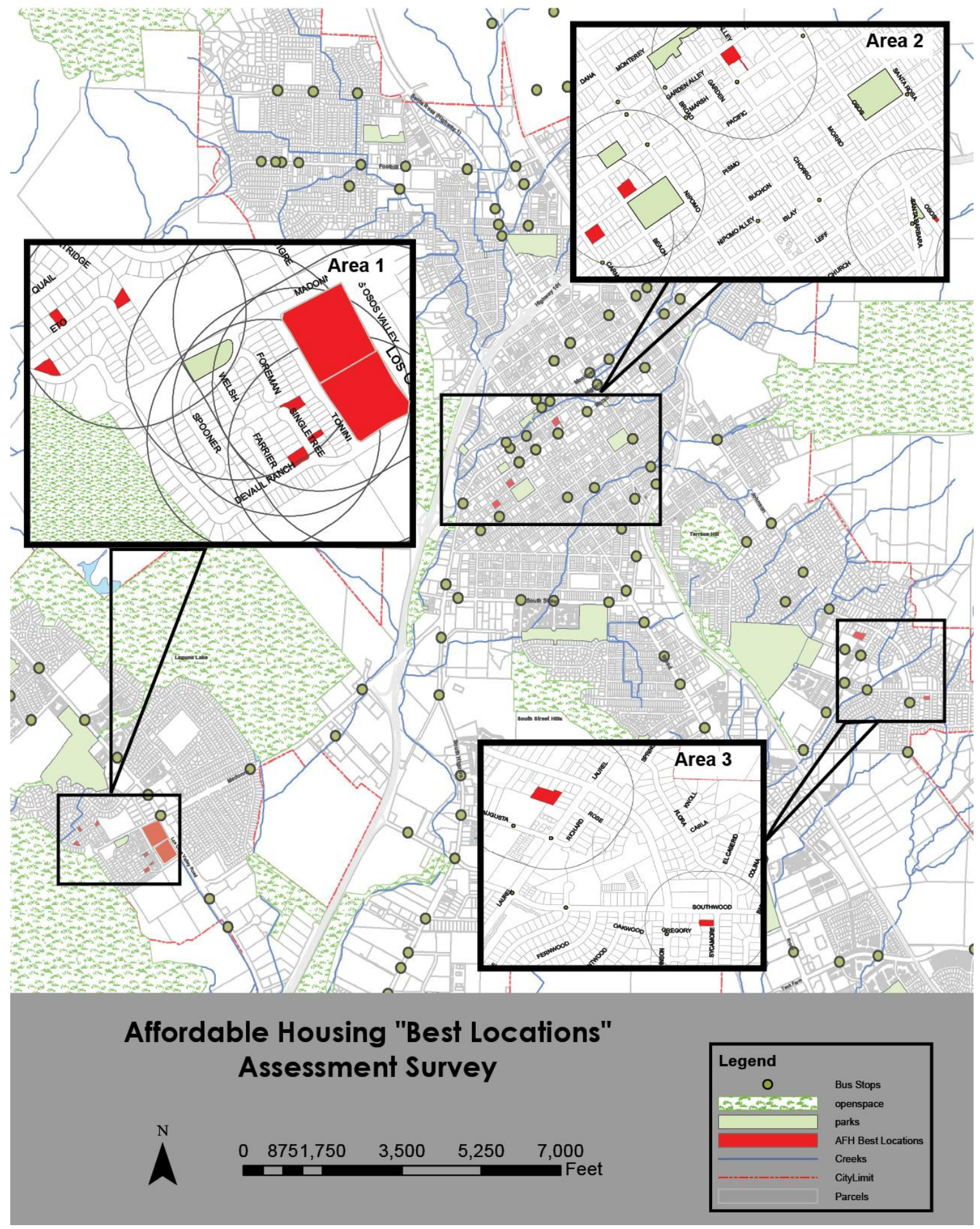




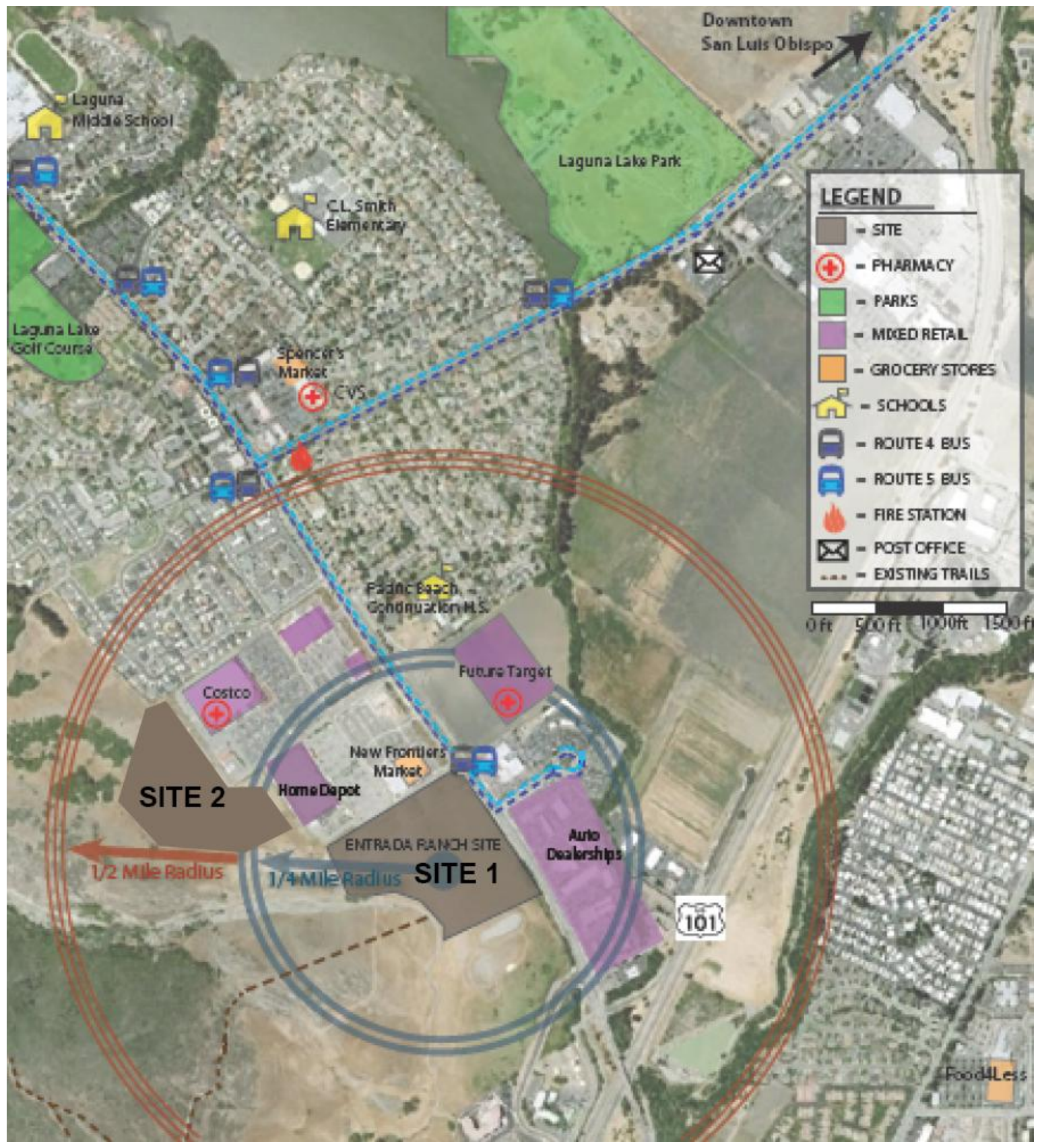

Source: Poly Housing Collaborative Bank of America Low Income Housing Challenge, 2011

Although the participants of the survey consider these examples as best locations, there still remains several site opportunities for affordable housing projects. Two sites in particular are along Los Osos Valley road.

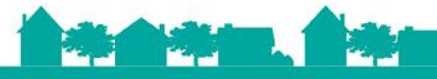


Figure 81 shows Site 1 which are currently under the jurisdiction of the County, but has been earmarked for future housing development. Site 2 shows the other possible site location for affordable housing and within the City limits. As you can see in figure 81 these two sites are located within walking distances of grocery stores, retail commercial and bus stops. The Poly Housing Collaborative team, developed a proposed plan called Entrada Ranch, which is specifically designed for affordable housing located on the larger of the two sites. A small sample of the project is located in Appendix $\mathrm{H}$.. Also the Margarita area and Orcutt area have both been recently annexed. They both have specific plans that can accompany 1,849 dwelling units, some in which can be affordable housing. The City hopes to accommodate at least 52 affordable units within the Margarita area specific plan, whereas the Orcutt area specific plan provides for about 147 affordable dwellings. Since, both plans are not centrally located, each plan calls for a mixed-use approach to provide basic amenities within walking distances for the future residents. 


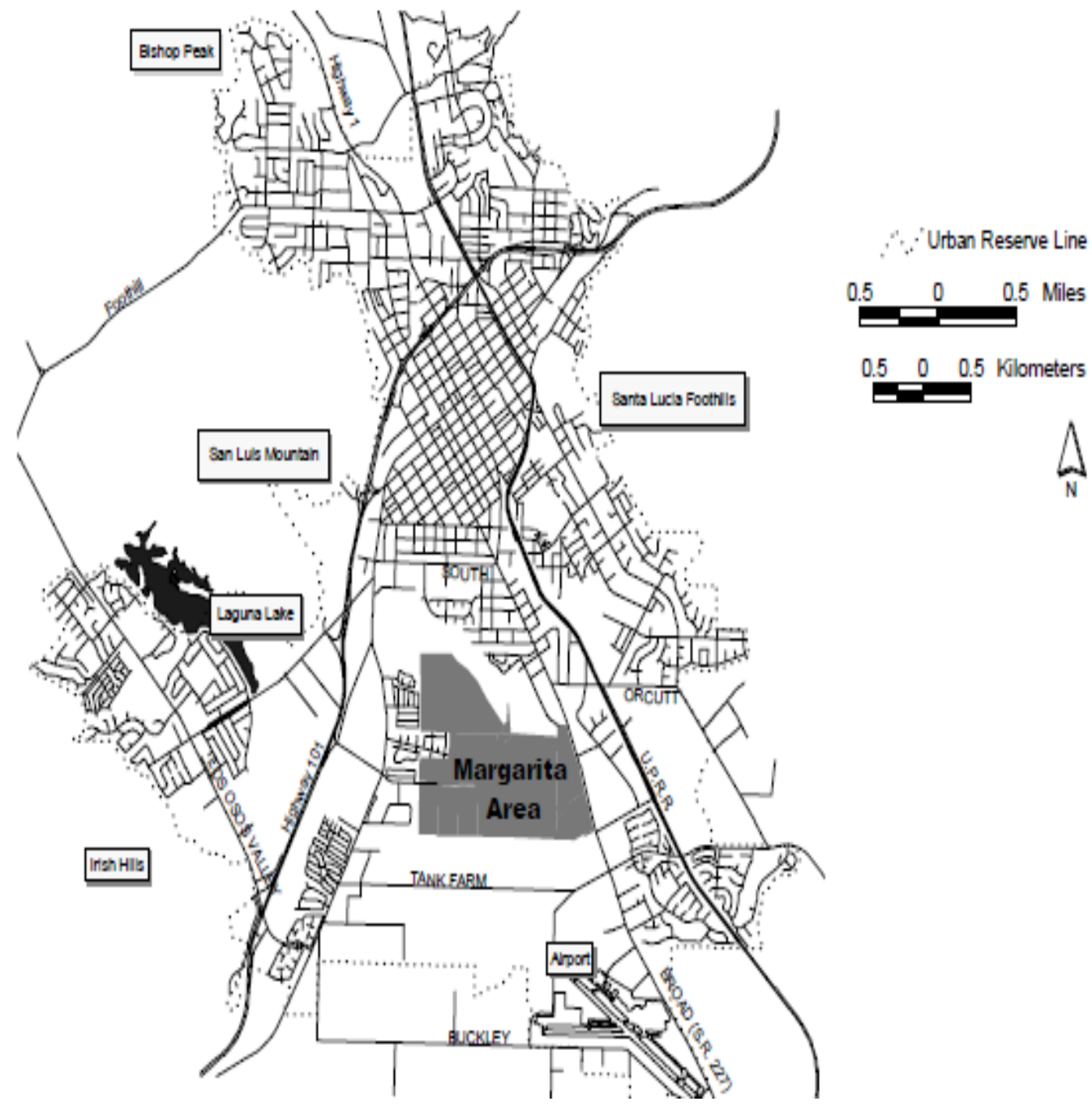

Source: City of San Luis Obispo Margarita Area Specific Plan, 2004 
Figure 83 Orcutt Area- Future Affordable Housing Site

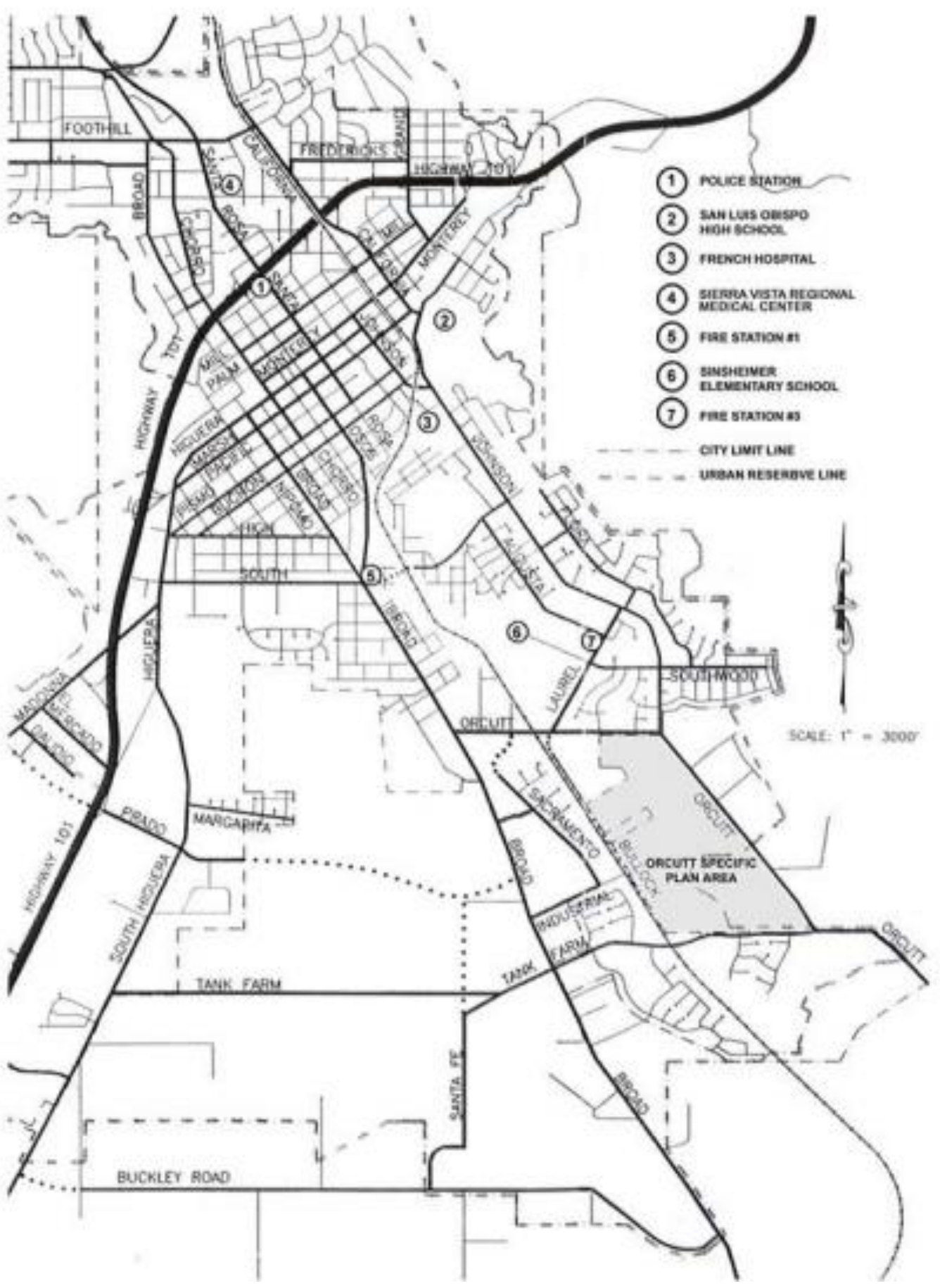

Source: City of San Luis Obispo Orcutt Area Specific Plan, 2010 


\subsection{DESIGN RECOMMENDATIONS FOR AFFORDABLE HOUSING IN}

SAN LUIS OBISPO

Based on the information gathered from the "best practices" case studies and the responses gathered from the assessment surveys, design recommendations were devised for the affordable housing units in San Luis Obispo. Overall, the survey responses were positive. Some negative comments included low quality of interior materials, lack of natural sunlight and parking issues. The design case studies incorporated multi-use facilities and state-of-the-art sustainable building practices, which were not mentioned in the returned surveys and do not seem to exist within the current affordable housing stock. With this gathered information a small list of broad design principles were created focusing on sustainable design and building practices, site planning, and architecture. These guiding principles reflect design recommendations for the affordable housing stock in San Luis Obispo.

\subsubsection{Sustainable Practices}

"The benefits of integrating sustainability and affordability include opportunities to evaluate and implement design features, building practices, and operational strategies that reduce consumption of natural resources, energy, and waste, while providing healthy, durable, and high quality homes" (Minnesota Green Affordable Housing Guide, 2010). In the development of a green affordable housing checklist, similar to the one developed by the City of Santa Monica (Appendix F) this type of tool can encourage developers of affordable housing projects to use environmentally sensitive building 
materials and systems. Only a few design recommendations to be considered for the future developments of affordable housing within San Luis Obispo are listed. These recommendations and categories could be the beginnings of a green affordable housing checklist for the City of San Luis Obispo.

\section{A. Building Materials}

1. Provide a well-insulated building that minimizes heat gain and loss with the use of recycled content insulation, such as recycled denim insulation, recycled newspaper, soy based foam, cotton or fiber.

2. Use recycled content consisting of rapidly renewable resource materials for flooring and finishes such as wheat straw board and bamboo.

3. Use locally available (within 500 miles) building materials that are recycled lumber or locally milled timber or Forest Stewardship Council (FSC) certified lumber.

\section{B. Lighting}

1. Provide natural day lighting with windows and skylights, but orienting the building to collect southern light exposure to the fullest.

\section{Indoor Air Quality}

1. Provide operable windows with screens to take advantage of natural cross-ventilation when possible.

2. Use low or no VOC paints, sealants, and finishes. 
3. Install flooring with low or no off-gassing such as concrete, ceramic tile, FSC certified wood flooring, or bamboo with low formaldehyde content.

4. Minimize the use of carpeting, which can hold dirt, mold and other allergens.

5. Install carbon monoxide detectors in living areas and garages.

\subsubsection{Architecture + Design}

As mentioned before, the architecture and design of affordable housing does not need to look affordable. With proper affordable housing design guidelines, the affordable units can be placed within a developed area and blend naturally with the surrounding spaces and places. Listed here are a few design recommendations.

1. The multi-family or single-family affordable housing should be designed to integrate the surrounding neighborhoods both in character and in scale of the existing buildings. If located in the Downtown Core, the Community Design Guidelines for Downtown should be followed.

2. The façades should be broken up with variations in color and texture in order to avoid stagnant, large-scale blank walls.

3. The stairways in the multi-family units should be designed to be hidden rather than a main focal point in the architecture.

\subsubsection{Access to Multi-Modal Transportation}


Many low-income households own fewer cars and drive less as described by HCD in their discussion about the top myths about affordable housing. In other words, residents of affordable housing need other modes of transportation to be convenient and easily accessible. The following is a brief recommendation for future affordable housing projects in relation to multi-modal transportation.

1. Provide for alternative transportation, e.g., bike paths, convenient bus stops car shares and pedestrian links.

2. Provide attractive well-lit pedestrian paths within the development and connect to existing public walkways.

3. Locate new developments within $1 / 4$ mile radius (equivalent to a 20 minute walk) of a bus stop and bike path.

\subsubsection{Access to Local Amenities}

Looking at the results from of assessment survey it appears that many residents were pleased with the convenience of near-by laundry facilities, but were often times far from bus stops and bike paths. The following recommendations were generated from the results retrieved from the assessment survey.

1. Locate new development $s$ within $1 / 4$-mile radius of a grocery or food store, laundry facilities and shopping.

2. Locate new developments within 1-mile radius of school, park(s) and open space and/or hiking trails. 
3. Locate new developments within 3-mile radius of a medical facility and affordable senior housing within 1-mile radius. 


\section{CONCLUSIONS AND FUTURE IMPLICATIONS}

Affordable housing continues to grow in San Luis Obispo. If the future of affordable housing in the City follows exemplary examples as discussed in Chapter 3, Chapter 5 and uses feedback obtained from the participants of the assessment survey it will surpass other affordable housing programs.

The development of the monitoring program is the beginning to a more all-encompassing affordable housing program. The monitoring program will ensure the current affordable housing units are being used appropriately and occupied by the correct and eligible people. The City wants to be sure all funding that go into the affordable housing projects are being used to house qualified residents. They want to be sure those that require living assistance receive it for as long as it is necessary.

While the suggested monitoring program will provide the base level of compliance and ensure the current stock is taken care of, additional efforts in supporting the development of affordable housing might include creating or forming a green affordable housing toolkit similar to the City of Santa Monica's green checklist (Appendix F). This checklist can serve as the basis for design guidelines specifically for affordable housing. By following green 
methods, it will save the developer money with incentives and the resident with lower utility cost.

However, the initial steps in enhancing the current affordable housing program have begun with the development of the monitoring program. The pilot run of the monitoring program proved to be very successful. Over 200 compliance questionnaires (Appendix C) were mailed out to owners, renters and property managers for the affordable housing units located within the City of San Luis Obispo. An initial utility check was done prior to mailing out the owner-compliance questionnaires. This entailed conducting a cross comparison between the name on the utility bill through the City's finance department and the name of the owner which was retrieved from the City's data system called Land Use. Once this check was done only four owner occupied units were sent questionnaires. This was because all the names matched the utility bills except for four owner occupied units. Since both the property manager and renter received a questionnaire, the City was able to conduct a side-by-side comparison to ensure both parties monthly rental rates matched. However, in the future only questionnaires will be sent to the property managers and owners. This initial analysis was only necessary for the pilot run to confirm both parties agreed upon the monthly rent.

The City received $100 \%$ of the owner questionnaires, $90 \%$ of the property management questionnaires and $80 \%$ of the renter questionnaires. The participants were given 2 weeks to respond and were provided a return stamp and envelope. 
Of all the questionnaires received only seven appeared to be out of compliance. The issue involved several units within one complex being charged extra for an attached garage and a monthly rent for a pet, which in turn pushed the overall monthly rent to exceed the Affordable Housing Standards. These flagged units are in breach of contract. The property owner will be receiving a notice in the mail to correct the violation within 30 days with the possibility of back pay owed to the renters. The enforcement of the out of compliant units are still being developed. Several meetings have been held with the City Attorney to discuss an aggressive action to correct the violations. Since this is only the beginning of the monitoring program, changes will occur as the affordable housing inventory increases and lessons are learned after the first enforcement action has taken place.

The future of the affordable housing program has room for multiple toolkits to help with conserving the current stock and enhancing the future developments. By using both the newly developed monitoring program along with a green affordable housing checklist, it can help enhance the affordable housing program in both quality assurance and preservation. The affordable housing program will not only be providing a place for lower income households, but will also be providing a well-designed, healthy environment. 


\section{BIBLIOGRAPHY}

1. Affordable Housing Design Advisor. Retrieved on November 22, 2011 from http://designadvisor.org/

2. AIA. (2010). Retrieved on March 4, 2012 from: http://www.aia.org/practicing/awards/AIAB083019

3. Alaghbari, Wa'el; Salim, Azizah; Dola, Kamariah; Abang Abdullah Abang Ali. (2011). Developing Affordable Housing Design for Low Income in Sana'a, Yemen. International Journal of Housing Markets and Analysis Vol.4. Â1, pages. 84-98.

4. Anonymous. (Winter 2010). The Washington Court Housing Survey: A Study of Accessibility and Universal Design in Affordable HousingExecutive Summary. Journal of Affordable Housing \& Community Development Law . Vol.19.Â, pages 191-204.

5. Arieff, Allison. Affordable Housing that Doesn't Scream Affordable. (October 2011). Retrieved November, 22, 2011 from http://www.theatlanticcities.com/design/2011/10/affordable-housingdoesnt-scream-affordable/326/

6. David Baker and Partners. (2008). Retrieved on March 4, 2012 from: http://www.dbarchitect.com/images/dynamic/projects/pdf//brochurem 2 0218 paseosenter.pdf

7. Basolo, Victoria. "City Spending on Economic Development Versus Affordable Housing: Does Inter-City Competition or Local Politics Drive Decisions?," Journal of Urban Affairs 22, no. 3 (September 1, 2000): 317-332.

8. Bohl,Charles, C., Rohe, William, M. and Watson, Harry, L. ( 2007). Chasing the American Dream. New York: Cornell University Press.

9. Calavita, Nico and Grimes, Kenneth. Inclusionary housing in California, 64150 (1998)

10. California Department of Housing and Community Development. Retrieved from http://www.hcd.ca.gov/

11. City of Pacific Grove. Retrieved from http://www.ci.pg.ca.us/boards/PC/minutes/2011/030311/7a.pdf

12. City of Pleasanton- Pleasanton Homeownership Assistance Program (PHAP) Survey

13. City/County of San Francisco (2007). Residential Inclusionary Affordable Housing Program Monitoring and Procedure Manual.Retrieved on March 30, 2012 from: http://sfmoh.org/Modules/ShowDocument.aspx?documentid=3216

14. City of San Luis Obispo Housing Element 2012, retrieved from http://slocity.org/communitydevelopment/housingelement2009/councila pprovedjanuary2010.pdf

15. Cocheo, Steve. "Affordable Housing: No Easy Answers," American Bankers Association. ABA Banking Journal 84, no. 10 (October 1992): 70. 
16. County of Santa Barbara. Housing and Community Development Department. Retrieved on March 30, 2012 from http://www.countyofsb.org/housing/default.aspx?id=4402

17. Design Matters-Best Practices in Affordable Housing. Retrieved from http://wall.aa.uic.edu:62730/ahc/catalog/search.html

18. Dewar, David. (Feb.2006). Guide Heralds Design Virtue. Planning 1656, page 20.

19. Edson, Charles L. "Affordable Housing-An Intimate History," Journal of Affordable Housing \& Community Development Law 20, no. 2 (Winter 2011): 193-213.

20. Ellwood, Mark (2010). All in the Detail. Financial Times Online.

Retrieved on February 29, 2012 from:

http://www.ft.com/intl/cms/s/0/655f2be6-2796-11dd-b7cb000077b07658.html?nclick check=1\#axzz1njkM88Dh

21. Enterprise Community Partners. (2012). Retrieved February 4, 2012 from: http://www.enterprisecommunity.com/solutions-andinnovation/design-leadership/affordable-housing-design-leadershipinstitute/ahdli-participants-and-projects

22. Erikson, Thor, (2010). The Process of Design for Affordable Housing in the Non-Profit Sector. (Master's Thesis). University of Cincinnati, Ohio.

23. Evans, Mariwyn "Making affordable housing work," Journal of Property Management 60, no. 2 (April 1995): 50.

24. Foong, Keat. "Experts provide affordable housing compliance tips at NAHMA conference," Multi - Housing News 38, no. 8 (August 2003): 4.

25. Forsyth,Ann, Nicholls, Gretchen, Raye, Barbara.(May 2012). Higher Density and Affordable Housing: Lessons from the Corridor Housing Initiative. Journal of Urban Design, Vol. 15. No. 2, pages 269-28.

26. Fulton, William \& Shigley, Paul. (2005). Guide to California Planning.California:Solano Press

27. Hall, Kenneth B., \& Porterfield, Gerald. (2001). Community by Design: New Urbanism for Suburbs and Small Communities. New York :McGrw-Hill

28. Harsch, Kelli et al., "Initiatives and Tools for the Preservation of Affordable Housing in Illinois," Journal of Affordable Housing \& Community Development Law 18, no. 4 (Summer 2009): 403-436.

29. Hayden, Kether. "Inclusionary Zoning for Increased Access to Affordable Housing in Los Angeles," Policy Studies Journal 35, no. 3 (August 2007): 550-551.

30. Hoving, Kimberly M, ( 2010 ). Mixed Income Housing: Assumptions and Realities. (Master's Thesis). California State University of San Luis Obispo, Ca.

31. Inhabitat. (2010).Affordable Artist Housing Helps Revitalize CA Town. Retrieved on February 4, 2012 from: http://inhabitat.com/affordableartist-housing-helps-revitialize-ca-town/arbor-lofts-5/ 
32. Kauffmann, Joanna. (Feb. 7, 2011). Partnership Works to Pair Good Design, Affordable Housing Arkansas Business. Vol. 28. Â6, page16.

33. Kimmelman, Michael "Via Verde in South Bronx Rewrites Low-IncomeHousing Rules," The New York Times, September 26, 2011, sec. Arts / Art \& Design, http://www.nytimes.com/2011/09/26/arts/design/viaverde-in-south-bronx-rewrites-low-income-housing-rules.html? $r=1$.

34. Lento, Rochelle E. "The Future of Affordable Housing," Journal of Affordable Housing \& Community Development Law 20, no. 2 (Winter 2011): 215-217.

35. Mallach, Alan. ( 2009). A Decent Home: Planning, Building, and Preserving Affordable Housing. Chicago: AIA.

36. Malone, Michael. (2010). The Architect's Guide to Residential Design. New York: Van Nostrand Reinhold Company.

37. Marin, Matthew.(2007). Green Initiatives Shapes Affordable Housing Model. Multi-Housing News. Vol. 42, Issue 11, page 8.

38. Martens, Betsey. Journal of Housing and Community Development 66. Â1 (Jan/Feb 2009): 6-8,10-12.

39. Minnesota Green Affordable Housing Guide. Retrieved March 20, 2012 from http://www.greenhousing.umn.edu/faq.html

40. O'Connell, Kim. (2004). Caught Between Housing and History. Journal of Housing and Community Development, Vol.61(5), pages 32-36

41. Preiser, Rabinowitz \& White Wolfgang F.E. (1988). Post-Occupancy Evaluation. New York: McGraw-Hill

42. PSL Architects. (2009). Retrieved on March 4, 2012 from: http://pslarchitects.com/arbor.html

43. Ralid, Renata C.B. (Unknown) Post Occupancy Evaluation as a tool for Better Quality Low-Income Housing: The Federal District's Vila Technolgica Project-Brazil. Retrieved from http://www.lth.se/fileadmin/hdm/alumni/papers/ad2001/ad2001-01.pdf

44. Rohe, William, M. and Watson, Harry, L. (2007). Chasing the American Dream. New York: Cornell University Press.

45. Rumpf, Bill. "Affordable Housing Preservation-The Sequel," Journal of Affordable Housing \& Community Development Law 20, no. 2 (Winter 2011): 243-245.

46. Rusk, David "Inclusionary Zoning: A Key Tool in the Search For Workable Affordable Housing Programs," PM. Public Management 88, no. 3 (April 2006): 18-20,22.

47. Sanoff, Henry. ( 2000 ). Community Participation in Design and Planning.Canada:John Wiley \& Sons

48. Schrand, Margaret "Banks and Affordable Housing-What Future?," Journal of Affordable Housing \& Community Development Law 20, no. 2 (Winter 2011): 237-239.

49. Southern Environmental Law Center. Retrieved on May 27, 2012.

Retrieved from: http://www.varems.org/connecting home and work.pdf 
50. Talen, Emily. (2010). Affordability in New Urbanist Development: Principle, Practice and Strategy. Journal of Urban Affairs. Volume 32, Number 4, pages 489-510.

51. Taylor, Waller. "Future of Affordable Housing \& Community Development," Journal of Affordable Housing \& Community Development Law 20, no. 2 (Winter 2011): 145-147.

52. The City of San Luis Obispo Community Development DepartmentHousing. Retrieved from http://slocity.org/communitydevelopment/housing/housing.asp

53. Tighe, J. Rosie "Public Opinion and Affordable Housing: A Review of the Literature," Journal of Planning Literature 25, no. 1 (2010): 3 -17.

54. Unknown. "Post-Occupancy Evaluation," Architecture Australia 100, no. 5 (Oct2011): 79.

55. U.S. Department of Housing and Development. Retrieved from http://portal.hud.gov/portal/page/portal/HUD

56. Williamson, Anne R. "Can They Afford the Rent? Resident Cost Burden in Low Income Housing Tax Credit Developments," Urban Affairs Review 47, no. 6 (November 1, 2011): 775 -799.

57. Wintford Thornton, "Public Financing for Creating Affordable Housing Options in the United States: Does It Work?," Real Estate Issues 30, no. 2 (Winter /2006 2005): 27-II.

58. York, Marie. (1991). The Orlando Affordable Housing Demonstration Project. American Planning Association. Journal of the American Planning Association, Vol. 57(4), pg. 490. 


\section{APPENDIX A: MONITORING PROGRAM PROCEDURES MANUAL(Deliverable to the City of San Luis Obispo)}




\section{2}

City of San Luis Obispo

Community

Development

Department

[AFFORDABLE HOUSING MONITORING

PROGRAM

PROCEDURES MANUAL] 


\section{PROGRAM OVERVIEW}

The Affordable Housing Monitoring Program was launch in April 2012. The purpose of this program is to ensure all of the City's affordable housing units are in compliance with the Municipal Code 17.91.160 (Management and Monitoring). The code states:

Inclusionary rental units shall be managed and operated by the property owner, or the owner's agent, for the term of the affordable housing agreement. Sufficient documentation shall be submitted to ensure compliance with this chapter, to the satisfaction of the director. (Ord.

$1508 \S 4$ (part), 2007)

The City wants to ensure that all owner occupied units are being occupied by the owner who signed the deed and promissory note and is not renting the unit without the owner residing at the residence. It is acceptable for the owner to rent out a room, but the owner must still be living on the property. The rental units must meet the Affordable Housing Standards set each year by the City. These standards are to be carried out by the property owner or property manager.

During the pilot program the City sent out three separate surveys; one for the renters, property management companies, and the owners. This initial study was to compare responses between the renter and property management company regarding the cost of rent and any additional fees. We wanted to be sure the responses were consistent with one another.

However, the future implementation of the Monitoring Program will only send out two surveys: property management surveys and owner surveys.

This manual will cover all the basic steps to implement the program with ease. As the program evolves, be sure to update the manual as needed. 


\section{PRIOR TO SENDING OUT SURVEYS}

\section{A. Affordable Housing Inventory:}

The Affordable Housing Inventory will continuously need to be updated as new projects are developed or a transfer in deed or title occurs. Before compiling the property and mailing addresses be sure the inventory is up to date. Also be sure that all listed properties in the Monitoring Program match the inventory list. If there are new addresses, copy and paste all the information from the inventory list to the Monitoring Program list. Location of the Affordable Housing inventory: [G: \CD-PLAN $\backslash$ Tcorey $\backslash L R \backslash A$ Affordable Housing \Affordable Housing Inventory]

* Please refer to the Affordable Housing Inventory Guidelines for more information on updating the inventory list: $\underline{G}: \backslash C D-P L A N \backslash T$ corey $\backslash L R \backslash$ Affordable $\underline{\text { Housing } \backslash \text { Affordable Housing Inventory } \backslash \text { Inventory Guidelines }}$

\section{B. Property Owner/Property Management Contact List:}

Before sending out the property management surveys make sure the property managers are still the same as listed in the Monitoring Program. This may be done by calling the property as listed online or seeing if the development has a website and retrieving information from there. You should also look in Land Use to get the property owners name if the rental is not being overseen by a property management company. Land Use is generally up to date with the owners name and mailing address.

*The property management list is the tab labeled Property Manager Info in the Monitoring Program Tracking Sheet. The tracking sheet location is discussed in Survey Tracking, Step 6. 


\section{INITIAL UTILITY CHECK}

Before sending out the surveys, you must first conduct a utility check for the owner occupied units. The utility check involves coordinating with the Jennifer Thompson in the Finance Department. [See sample initial utility check list sent and received by finance department on the following page]

1. Compose a excel sheet with all the owner addresses and owners' names. You can obtain the name of the owner through Land Use. (shortcut on desktop)

2. Send the list via email to Jennifer Thompson in Finance at jthompson@slocity.org

3. Ask her to check the utility bills against the addresses and names you have provided.

4. If they all come back matching the utility bills, you do not need to send out any of the owner surveys. Only send out surveys to the owners that show a discrepancy.

* Please note that this utility check is only for the owner occupied units, this does not include the property managers or property owners. 
SAMPLE

SENT UTILITY CHECKLIST

\begin{tabular}{|c|c|c|c|c|c|}
\hline $\begin{array}{l}\text { Number } \\
\text { of Units }\end{array}$ & Income Rate & $\begin{array}{l}\text { Rent/ } \\
\text { Own }\end{array}$ & Owner & $\#$ & Address \\
\hline 1 & MODERATE & Owner & Amy Lynne Hilderbrand & 3596 & BROAD \#202 \\
\hline 1 & MODERATE & Owner & Jeffrey W Sebern & 1963 & DEVAUL RANCH \\
\hline 1 & MODERATE & Owner & Kristen Fahs & 1965 & DEVAUL RANCH \\
\hline 1 & MODERATE & Owner & Briana Heywood & 1079 & ELLA \#3 \\
\hline 1 & MODERATE & Owner & Jennifer Beck & 1075 & ELLA \#3 \\
\hline 1 & VERY LOW & Owner & Emily Worrell & 1043 & ELLA \#8 \\
\hline 1 & MODERATE & Owner & Joseph \& Monica Reichmuth & 1582 & ETO \\
\hline 1 & MODERATE & Owner & Julie Fallon & 1586 & ETO \\
\hline 1 & MODERATE & Owner & John and Monica Marchetti & 1588 & ETO \\
\hline 1 & MODERATE & Owner & Samual and Dana Wooten & 1590 & ETO \\
\hline 1 & MODERATE & Owner & James and Hollie Buchanan & 1594 & ETO \\
\hline 1 & MODERATE & Owner & Greg Shearer & 1596 & ETO \\
\hline 1 & MODERATE & Owner & Josephine Sepulveda & 1598 & ETO \\
\hline 1 & MODERATE & Owner & Michael Wellman & 1724 & FARRIER \\
\hline 1 & MODERATE & Owner & Kathleen Ruiz & 1645 & FOREMAN \\
\hline 1 & MODERATE & Owner & Kevin Sass & 1664 & FOREMAN \\
\hline 1 & MODERATE & Owner & Harry and Della Coelho & 1680 & FOREMAN \\
\hline 1 & & Owner & Stephen Sicanoff & 1720 & JOHNSON \\
\hline 1 & LOW \& MODERATE & Owner & Patricia Galvan & 759 & LAWRENCE \\
\hline 1 & LOW \& MODERATE & Owner & Douglas Williams & 811 & LAWRENCE \\
\hline 1 & LOW \& MODERATE & Owner & Lori Stowe & 913 & LAWRENCE \\
\hline 1 & VERY LOW & Owner & Juan and Maria Rodriguez & 1320 & PHILLIPS \\
\hline 1 & VERY LOW & Owner & John and Jamie Avrett & 1324 & PHILLIPS \\
\hline 1 & MODERATE & Owner & Beth and Matthew Lodge & 2975 & Rockview \#19 \\
\hline 1 & MODERATE & Owner & Sabrina Haggie & 3591 & Sacramento \#10 \\
\hline 1 & MODERATE & Owner & Jamie Ballew & 3591 & Sacramento \#59 \\
\hline 1 & MODERATE & Owner & Michael Sathre 233 Mayfield Ct Newberry Park & 564 & SANDERCOCK \\
\hline 1 & MODERATE & Owner & Amanda and Parish Ruth & 1712 & SINGLETREE \\
\hline 1 & MODERATE & Owner & Francisco Vazquez & 1800 & SPOONER \\
\hline 1 & & Owner & & 902 & Tarragon \\
\hline 1 & & Owner & & 904 & Tarragon \\
\hline 1 & & Owner & & 910 & Tarragon \\
\hline 1 & & Owner & & 914 & Tarragon \\
\hline 1 & & Owner & & 916 & Tarragon \\
\hline 1 & & Owner & & 922 & Tarragon \\
\hline 1 & & Owner & & 928 & Tarragon \\
\hline 1 & & Owner & & 932 & Tarragon \\
\hline 1 & & Owner & & 934 & Tarragon \\
\hline 1 & & Owner & & 936 & Tarragon \\
\hline 1 & MODERATE & Owner & Lisa Castello & 1651 & TONINI \\
\hline 1 & MODERATE & Owner & Debra D Thompson & 1683 & TONINI \\
\hline 1 & MODERATE & Owner & Tania L Daniel & 1715 & TONINI \\
\hline 1 & MODERATE & Owner & Andreas Devitt & 1773 & TONINI \\
\hline 1 & MODERATE & Owner & Heidi L Hopkins & 1775 & TONINI \\
\hline 1 & MODERATE & Owner & Amanda \& Kevin Selman & 1799 & TONINI \\
\hline \multirow[t]{4}{*}{1} & MODERATE & Owner & Anna \& Nicholas Brannen & 2862 & VICTORIA \\
\hline & & Vacant & & & \\
\hline & & & & & \\
\hline & & & & & \\
\hline
\end{tabular}




\section{SAMPLE \\ RECEIVED UTILITY CHECKLIST}

\begin{tabular}{|c|c|c|c|c|c|}
\hline Income Rate & $\begin{array}{l}\text { Rent/ } \\
\text { Own }\end{array}$ & Owner & $\#$ & Address & Mailing Address \\
\hline MODERATE & Owner & Amy Lynne Hilderbrand & 3596 & BROAD \#202 & Same \\
\hline MODERATE & Owner & Jeffrey W Sebern & 1963 & DEVAUL RANCH & Same \\
\hline MODERATE & Owner & Kristen Fahs & 1965 & DEVAUL RANCH & Same \\
\hline MODERATE & Owner & Briana Heywood & 1079 & ELLA \#3 & Same \\
\hline MODERATE & Owner & Jennifer Beck & 1075 & ELLA \#3 & Same \\
\hline VERY LOW & Owner & Emily Worrell & 1043 & ELLA \#8 & Same \\
\hline MODERATE & Owner & Joseph \& Monica Reichmuth & 1582 & ETO & Same \\
\hline MODERATE & Owner & Julie Fallon & 1586 & ETO & Same \\
\hline MODERATE & Owner & John and Monica Marchetti & 1588 & ETO & Same \\
\hline MODERATE & Owner & Samual and Dana Wooten & 1590 & ETO & Same \\
\hline MODERATE & Owner & James and Hollie Buchanan & 1594 & ETO & $\begin{array}{c}\text { Name on utility account: Sherri L Canaday. Was in the name James } \\
\text { Buchanan until July } 2011 .\end{array}$ \\
\hline MODERATE & Owner & Greg Shearer & 1596 & ETO & Same \\
\hline MODERATE & Owner & Josephine Sepulveda & 1598 & ETO & Same \\
\hline MODERATE & Owner & Michael Wellman & 1724 & FARRIER & Same \\
\hline MODERATE & Owner & Kathleen Ruiz & 1645 & FOREMAN & Same \\
\hline MODERATE & Owner & Kevin Sass & 1664 & FOREMAN & $\begin{array}{l}\text { Name on utility account: Evan Melgares. Was in the name Kevin Sass } \\
\text { until October 2011. His final bill was mailed to } 521 \text { Crocker St Templeton } \\
93465-5109\end{array}$ \\
\hline MODERATE & Owner & Harry and Della Coelho & 1680 & FOREMAN & Same \\
\hline & Owner & Stephen Sicanoff & 1720 & JOHNSON & Same \\
\hline LOW \& MODERATE & Owner & Patricia Galvan & 759 & LAWRENCE & Same \\
\hline LOW \& MODERATE & Owner & Douglas Williams & 811 & LAWRENCE & Same \\
\hline LOW \& MODERATE & Owner & Lori Stowe & 913 & LAWRENCE & Same \\
\hline VERY LOW & Owner & Juan and Maria Rodriguez & 1320 & PHILLIPS & Same \\
\hline VERY LOW & Owner & John and Jamie Avrett & 1324 & PHILLIPS & Same \\
\hline MODERATE & Owner & Beth and Matthew Lodge & 2975 & Rockview \#19 & $\begin{array}{l}2975 \text { Rockview not individually metered. All dwelling units combined on } \\
\text { one utility account. }\end{array}$ \\
\hline MODERATE & Owner & Sabrina Haggie & 3591 & Sacramento \#10 & Same \\
\hline MODERATE & Owner & Jamie Ballew & 3591 & Sacramento \#59 & Same \\
\hline MODERATE & Owner & Michael Sathre 233 Mayfield Ct Newberry Park & 564 & SANDERCOCK & $\begin{array}{l}\text { Name on utility account: John Galbreath. Was in the name Michael } \\
\text { Sathre until January } 2011 .\end{array}$ \\
\hline MODERATE & Owner & Amanda and Parish Ruth & 1712 & SINGLETREE & Same \\
\hline MODERATE & Owner & Francisco Vazquez & 1800 & SPOONER & Same \\
\hline & Owner & Nathan Ryan and Marissa Perona & 862 & Tarragon & Same \\
\hline & Owner & William and Shelby West & 864 & Tarragon & Same \\
\hline & Owner & Michael Randall & 852 & Tarragon & Same \\
\hline & Owner & Erik Johnson & 844 & Tarragon & Same \\
\hline & Owner & Airlin Singewald & 858 & Tarragon & Same \\
\hline & Owner & David Lamb & 842 & Tarragon & Same \\
\hline & Owner & Margo Anderson & 866 & Tarragon & Same \\
\hline & Owner & William Lawrence & 830 & Tarragon & Same \\
\hline & Owner & Bret and Margaret Bodemer & 832 & Tarragon & Same \\
\hline & Owner & Luke Wallace & 838 & Tarragon & Same \\
\hline MODERATE & Owner & Lisa Castello & 1651 & TONINI & Same \\
\hline MODERATE & Owner & Debra D Thompson & 1683 & TONINI & Same \\
\hline MODERATE & Owner & Tania L Daniel & 1715 & TONINI & $\begin{array}{l}\text { Account in the name Tania L Daniel. Billing address: PO Box } 105 \text { San } \\
\text { Luis Obispo } 93406-0105\end{array}$ \\
\hline MODERATE & Owner & Andreas Devitt & 1773 & TONINI & Same \\
\hline MODERATE & Owner & Heidi L Hopkins & 1775 & TONINI & Same \\
\hline MODERATE & Owner & Amanda \& Kevin Selman & 1799 & TONINI & Same \\
\hline MODERATE & Owner & Anna \& Nicholas Brannen & 2862 & VICTORIA & Same \\
\hline
\end{tabular}




\section{SURVEY TEMPLATES}

There are two separate surveys you will be sending out: property management and owner surveys. These templates can be found in: IG: \CD-PLAN \Tcorey $\backslash L R \backslash$ Affordable Housing $\backslash$ Affordable Housing Monitoring Program $\backslash 3$. Survey Template].

To make any adjustments or changes to the template be sure to make edits in the appropriate InDesign files. Be sure not to save over the original. Make sure to label the new file as:

\section{Compliance_Survey_PM_Year or Compliance_Survey_Owner_Year.}

On the front side of the templates is a space for the property address. The property address refers to the address we are checking the compliance status; this is not necessarily the mailing address [See Sample Templates on Next Page]. Before submittal to the printing company be sure to create an excel spread sheet that lists property addresses and mailing addresses in separate columns. There will be two spreadsheets (tabs): one with the list of mailing addresses and property addresses for the property management surveys and another one for the owners [See Sample]. The location of this file is: [G: $\backslash C D-$ PLAN $\backslash$ Tcorey $\backslash L R \backslash$ Affordable Housing $\backslash$ Affordable Housing Monitoring Program $\backslash 3$. Survey Templates $\backslash$ Mailing-Property Address List] Also don't save over the original, make sure to save the new file with the appropriate year.

$\checkmark$ Be sure to check with Ryan Betz to find out if the printing company wants the City, State and Zip all in one column or separated into individual columns. 


\section{SAMPLE \\ SURVEY TEMPLATE-Property Management}

city of
san luis obıspo

$\widehat{A H M P}$

AFFORDABLE HOUSING

Monitoring Program

This is a compliance check that will be distributed on an annual basis to ensure that the affordable housing unit listed below is operating in compliance with the units' Affordable Agreement and Affordable Housing Standards set forth by the City.

Failure to complete and return this form to the City by 20 is a violation of Municipal Code 17.91.160 (Management and Monitoring).

A stamped envelope and return address have been provided for your convenience.

Your cooperation is appreciated. If you have any questions concerning this compliance check, please contact Tyler Corey, Housing Programs Manager, at 805. 781.7169 or via email Tcorey@slocity.org.
[Property Management Compliance Check]
Property Address:

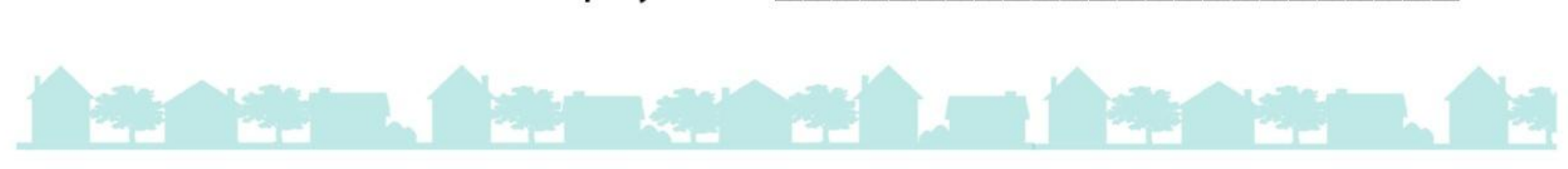

[1] What is the number of bedrooms in the unit?

Studio

1 Bedroom

2 Bedroom

3 Bedroom

4+ Bedroom
[2] Do you currently reside at the residence listed on this survey?
Thank you for your time.

[2a] If you do not reside at the residence, are you renting out the entire property?

$$
\begin{aligned}
& \square \text { Yes } \\
& \square \text { No }
\end{aligned}
$$

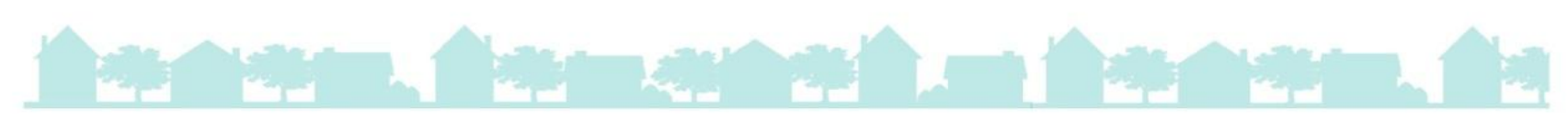




\section{SAMPLE \\ SURVEY TEMPLATE-Owner}

city of
san luis obispo AMHP
AFFORDABLE HOUSING
Monitoring Program

[Owner Survey]
This survey is being conducted by the City of San Luis Obispo on an annual basis in order to obtain statistical information and to ensure all affordable units located within the City are in compliance with Affordability Agreements and Affordable Housing Standards set by the City.

Please complete and return the survey no later than $20 \ldots$. A stamped envelope and return address have been provided for your convenience.

Your cooperation is greatly appreciated. If you have any questions concerning this letter or the survey, please feel free to contact Tyler Corey, Housing Programs Manager, at 805.781.7169 or via email Tcorey@slocity.org.

\section{Property Address:}

[1] What is the number of bedrooms in the unit?

$\square$ Studio

$\square 1$ Bedroom

$\square 2$ Bedroom

3 Bedroom

$\square$ 4+ Bedroom
[2] Do you currently reside at the residence listed on this survey?

$$
\begin{aligned}
& \square \text { Yes } \\
& \square \text { No }
\end{aligned}
$$
are you renting out the entire property? $\square$ Yes

Thank you for your time.

$\square$ No 


\section{MAILING OUT THE SURVEYS}

The processes of mailing out the compliance surveys will be through an outside source (i.e. Poor Richards Press). Be sure to clearly explain either via email or over the phone the exact contents of the survey. Contents of the survey are:

A. The Property Management or Owner Survey (references the property address on the front side of the survey)

B. A return envelope with stamp addressed to: Community Development Department ATTN: Tyler Corey- Housing Programs Manager City of San Luis Obispo 919 Palm Street

San Luis Obispo, CA 93401-3218

C. The exterior mailing envelope (references the mailing address)

However, the surveys must be prepared before sending off to the printing company. The participant should be allowed a $\mathbf{3 0}$ day response period. Make sure to update the return date on the surveys to reflect $\mathbf{3 0}$ days prior to mailing out the surveys. In addition to the "return no later than" date, allow an additional two weeks for printing and packaging. You may use Poor Richards Press or another printing company who will merge all addresses from the excel mailing list onto the survey templates, package them with return envelopes and mail out all the surveys. Please be aware this takes time, possibly two weeks, but be sure to ask the company for a job time estimate. When applying a return date be sure to add about $\mathbf{2}$ weeks to the $\mathbf{3 0}$ day turn around period. [Samples to follow this page].

\section{SURVEY TRACKING}


The first step is to print out the addresses for the property management and one for the owner. These lists are those generated for the printing company (5. Mailing Out The Surveys). As you receive surveys be sure to check them off the list. Next you will track the answers to the surveys in the excel spreadsheet called Monitoring Program Tracking. There will be multiple tabs set-up: one will be labeled Compliance Survey Year-PM (property management) and another Compliance Survey Year-Owner. Be sure to write in the year the compliance check is being done. For example the 2012 survey tabs were labeled Compliance Survey 2012-PM. You will see for 2012 a renters tab, ignore that tab. Remember this was part of the pilot program and won't be continued. Just create a PM and Owners tab with the year. The link to the Monitoring Program is found here: [G: \CD-PLAN \Tcorey $\backslash L R \backslash A$ ffordable Housing \Affordable Housing Monitoring Program $\backslash 6$. Survey Tracking $\backslash$ Tracking Spreadsheet]

If someone doesn't answer a questions just write N/A or leave blank. Some of the participants will be sending in a copy of their income certification. If this is attached be sure to scan it in and add a hyperlink in the Copy of Income Certification column. This is only asked from the property management and if they don't have them on file, we can follow-up with HALSO (Housing Authority of San Luis Obispo) and retrieve the remaining ones that are missing. See Tyler Corey for information on retrieving copies of income certifications from HALSO.

Be sure to flag any properties that may be out of compliance, i.e. renting out an owner occupied unit or exceeding the Affordable Housing Standards for rent. These properties will need to be further examined and possibly brought to the attention of the City Attorney. See the following section for procedures surrounding out of compliance properties. [Sample follows this page]. 


\section{SAMPLE}

\section{SURVEY TRACK SNAPSHOT}

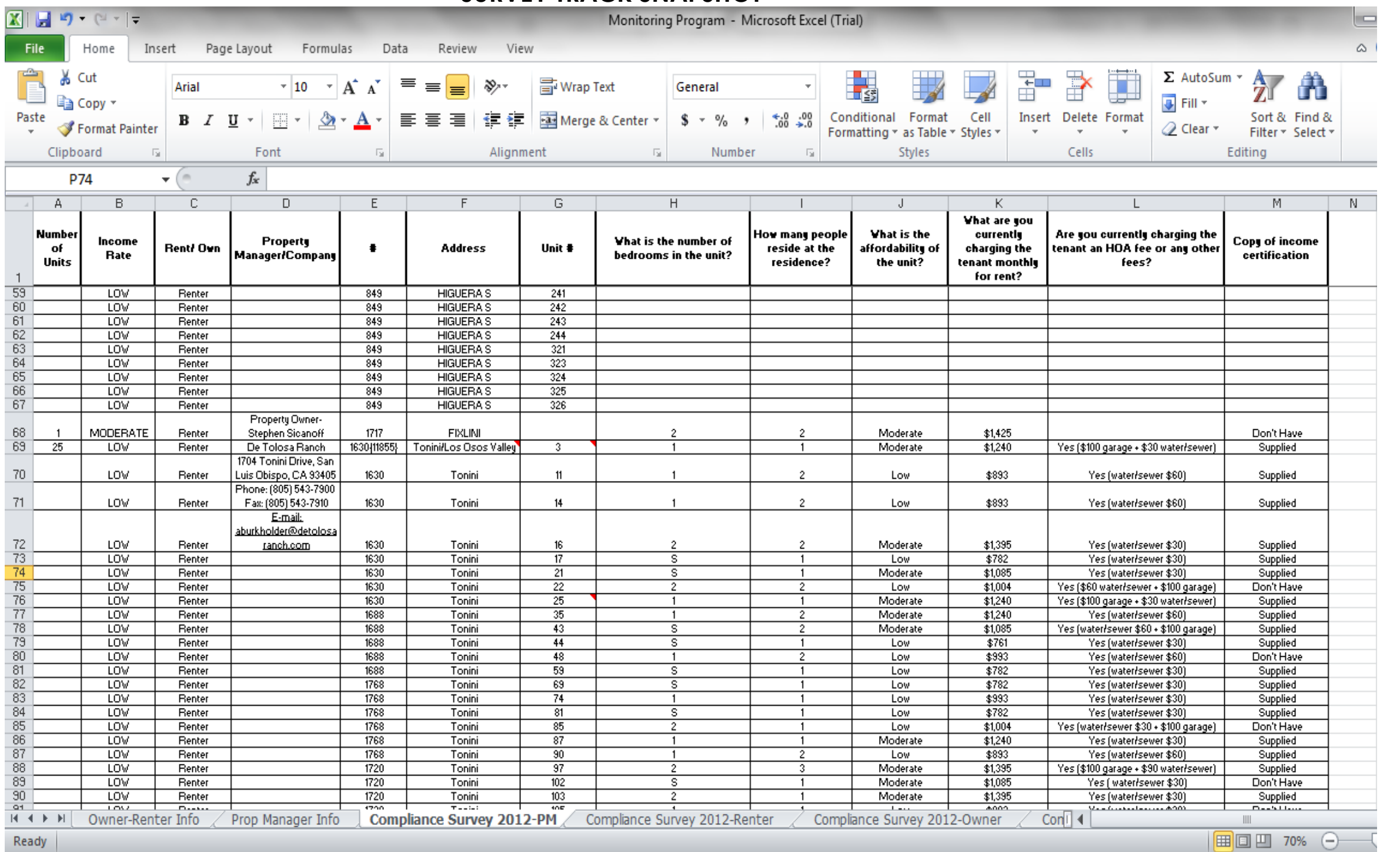

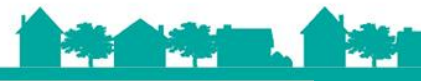




\section{OUT OF COMPLIANCE PROPERTIES}

During our pilot run of the program in 2012 we did flag several rental units that appeared to be out of compliance. The management company for the property was charging $\$ 100$ extra a month for garages and $\$ 35$ a month for pet rent. These extra fees pushed several unit rents over the maximum allowed by the City's Affordable Housing Standards.

If any properties are out of compliance schedule a meeting with the City Attorney. If this is a property management company or property owner charging rents exceeding the standards, try to obtain a copy of the lease agreement to give to the City Attorney. A copy of the lease agreement will provide the City Attorney with proof that the renters are being charge over the allowed amount. For those units or properties out of compliance, create an excel template with the property address, the rent being charge, extra charges (if any) and the total amount being charged (add the rent and extra fees). A sample can be seen following this page. Also include the Affordable Housing Standards amount for the appropriate year. The template

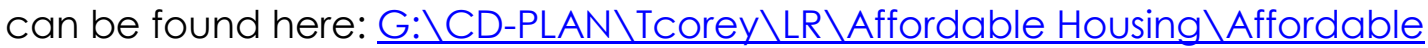
Housing Monitoring Program $\backslash 7$. Out of Compliance Properties $\backslash$ Out of Compliance Template.

Be sure not to save over the original. Rename the file with the corresponding year and save. Be sure to bring the "out of compliance" surveys and excel sheet you had just created to the meeting. The City Attorney will ask you to draft a letter to be sent to the "out of compliance" property(ies). She will then add the legal ramifications to your letter. The more information you add to the letter the better. In some cases involving renters being charged over the standards, the City Attorney may ask the property owner to pay back renters the additional money that they have collected that exceeded the standards within a one to four year period. See the City Attorney for guidance for enforcement procedure for both owner and rental properties. [Sample draft letter on next page]. 


\section{SAMPLE \\ CITY ATTORNEY DRAFT LETTER}

*To be added later

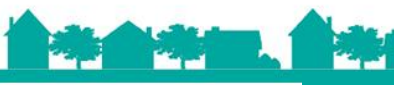




\section{Appendix B: ASSESSMENT SURVEY TEMPLATE}

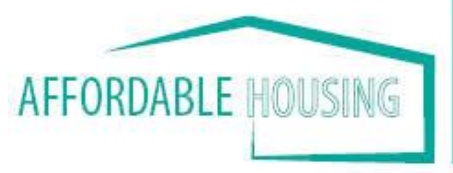

\section{Affordable Housing Survey \\ City of San Luis Obispo}

\section{CALPOIY CRP}

This survey will help to assess the current conditions and quality of the affordable housing units in San Luis Obispo. Please take a moment to complete the survey.

1. Gender

$\square$ Male

$\square$ Female

2. Age Group:
$\square$ 18-25
$\square$ 26-35
$\square$ 36-45
$\square$ 46-55
$\square 56-65$
$\square$ Over 65 years

3. Do you rent or own?
$\square$ Rent
$\square$ own

4. How many bedrooms?
$\square$ studio
$\square 1$
$\square 2$
$\square 3$
$\square 4+$

5. How many bathrooms?
$\square 1$
$\square^{3+}$

6. What type of home do you live in?

$\square$ Detached SFR (single family residence)

$\square$ semi-detached ( 2 house joined together)

$\square$ Multi-family (apartment style)

$\square$ other

7. Which of the following parking facilities do you have?

$\square$ Garage

$\square$ Carport

$\square$ Open-Air Designated Parking Spot

$\square$ street Parking

$\square$ No Parking

$\square$ other

8. All in all , how would you rate the build quality and condition of your home?
$\square$ Excellent
$\square$ Good
$\square$ Fair
$\square$ Poor

11. Do you have energy saving appliances? (energy star, water saving) $\square$ Yes

$\square$ No

11a. If so, which of the following are energy saving appliances?

$\square$ Washer

$\square$ Dryer

$\square$ Refrigerator

$\square$ Dishwasher

$\square$ Water Heater

$\square$ other

12. In an average work week, how many hours do you spend in the following types of spaces: (place a check mark in the appropriate box)

\begin{tabular}{|c|c|c|c|c|c|c|c|c|c|}
\hline & \begin{tabular}{|l|l|} 
Ling \\
Room \\
\end{tabular} & Dining Room & Kitchen & \begin{tabular}{|l} 
Messter \\
Bedrocm
\end{tabular} & Bedroom & Battroom & Garage & \begin{tabular}{|l|} 
Common \\
Space \\
\end{tabular} & \begin{tabular}{|l|} 
Batcoonyl \\
Patio \\
\end{tabular} \\
\hline 0 to5 & & & & & & & & & \\
\hline 6 to 10 & & & & & & & & & \\
\hline 11 to 15 & & & & & & & & & \\
\hline 16 to 20 & & & & & & & & & \\
\hline 21 to 25 & & & & & & & & & \\
\hline 26 to 30 & & & & & & & & & \\
\hline $30+$ & & & & & & & & & \\
\hline
\end{tabular}

13. Please rate the following on a scale from 1 (poor) to 5 (excellent) for the areas specified in the chart. (please write in 1,2,3,4 or 5 in the boxes)

\begin{tabular}{|l|l|l|l|l|}
\hline & $\begin{array}{c}\text { Air } \\
\text { Quality }\end{array}$ & Ventilation & $\begin{array}{c}\text { Natural } \\
\text { Lighting }\end{array}$ & $\begin{array}{c}\text { Heating/ } \\
\text { Cooling }\end{array}$ \\
\hline Living & & & & \\
Room & & & & \\
\hline $\begin{array}{l}\text { Dining } \\
\text { Room }\end{array}$ & & & & \\
\hline Kitchen & & & & \\
\hline $\begin{array}{l}\text { Master } \\
\text { Bedroom }\end{array}$ & & & & \\
\hline Bedroom & & & & \\
\hline Bathroom & & & & \\
\hline
\end{tabular}




\section{Appendix B: ASSESSMENT SURVEY TEMPLATE}

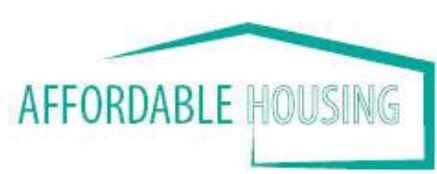

14. If you are currently working, where is your job located?

$\square$ San Luis Obispo

$\square$ Avila Beach

$\square 5$ Cities Area

$\square$ Santa Maria

$\square$ Atascadero

$\square$ Templeton

$\square$ Paso Robles

$\square$ Other

15. How far do you travel for work?

$$
\begin{aligned}
& \square \text { 0-5 miles } \\
& \square 5-10 \text { miles } \\
& \square 10-15 \text { miles } \\
& \square 15+\text { miles }
\end{aligned}
$$

16. What is your primary mode of transportation?

$$
\begin{aligned}
& \square \text { Auto } \\
& \square \text { Bus } \\
& \square \text { Bike } \\
& \square \text { Walk } \\
& \square \text { Other }
\end{aligned}
$$

17. What is your secondary mode of transportation?

$$
\begin{aligned}
& \square \text { Auto } \\
& \square \text { Bus } \\
& \square \text { Bike } \\
& \square \text { Walk } \\
& \square \text { Other }
\end{aligned}
$$

\section{Affordable Housing Survey}

City of San Luis Obispo

\section{$\underline{\text { CALPOLY }}$ CRP}

18. Please place a check mark in the following boxes to indicate distances to surrounding services.

\begin{tabular}{|l|l|l|l|}
\hline & $\begin{array}{l}\text { within } \\
1 / 4 \text { mile }\end{array}$ & $\begin{array}{l}\text { within } \\
1 / 2 \text { mile }\end{array}$ & $\begin{array}{l}\text { within } \\
1 \text { mile }\end{array}$ \\
\hline Groceries & & & \\
\hline School & & & \\
\hline Bus Stop & & & \\
\hline Park(s) & & & \\
\hline BikePath & & & \\
\hline Shopping & & & \\
\hline Laundry & & & \\
Facilities & & & \\
\hline Hiking Trails & & & \\
\hline Other & & & \\
\hline
\end{tabular}

19. If you could change 3 things about your home what would those be?

1

2

3.

20. List the features of your home that you are the most satisfied with?

21. Additional Comments:

Thank You for Participating in our Survey! 


\section{Appendix C: COMPLIANCE SURVEY TEMPLATE (Side One)}

crity of san luis obispo

$\widehat{\mathrm{AMHP}}$

AFFORDABLE HOUSING

Monitoring Program

This survey is being conducted by the City of San Luis Obispo on an annual basis in order to obtain statistical information and to ensure all affordable units located within the City are in compliance with Affordability Agreements and Affordable Housing Standards set by the City.

Please complete and return the survey no later than 20__ A stamped envelope and return address have been provided for your convenience.

Your cooperation is greatly appreciated. If you have any questions concerning this letter or the survey, please feel free to contact Tyler Corey, Housing Programs Manager, at 805.781 .7169 or via email Tcorey@slocity.org.

[Owner Survey]

Property Address:

city of san luis obispo

$\widehat{\mathrm{AMHP}}$

AFFORDABLE HOUSING Monitoring Program

[Renter Survey]
This survey is being conducted by the City of San Luis Obispo on an annual basis in order to obtain statistical information and to ensure all affordable units located within the City are in compliance with Affordability Agreements and Affordable Housing Standards set by the City.

Please complete and retum the survey no later than $20 \_$A stamped envelope and return address have been provided for your convenience.

Your cooperation is greatly appreciated. If you have any questions conceming this letter or the survey, please feel free to contact Tyler Corey, Housing Programs Manager, at 805.781 .7169 or via email Tcorey@slocity.org.

Property Address: city of san luis obispo

\section{$\widehat{\mathrm{AMHP}}$}

AFFORDABLE HOUSING Monitoring Program
This survey is being conducted by the City of San Luis Obispo on an annual basis in order to obtain statistical information and to ensure all affordable units located within the City are in compliance with Affordability Agreements and Affordable Housing Standards set by the City.

Please complete and retum the survey no later than 20_ A stamped envelope and return address have been provided for your convenience.

Your cooperation is greatly appreciated. If you have any questions concerning this letter or the survey, please feel free to contact Tyler Corey, Housing Programs Manager, at 805.781 .7169 or via email Tcorey@slocity.org.

[Property Management Survey]

Property Address: 


\section{Appendix C: COMPLIANCE SURVEY TEMPLATE (Side Two)}

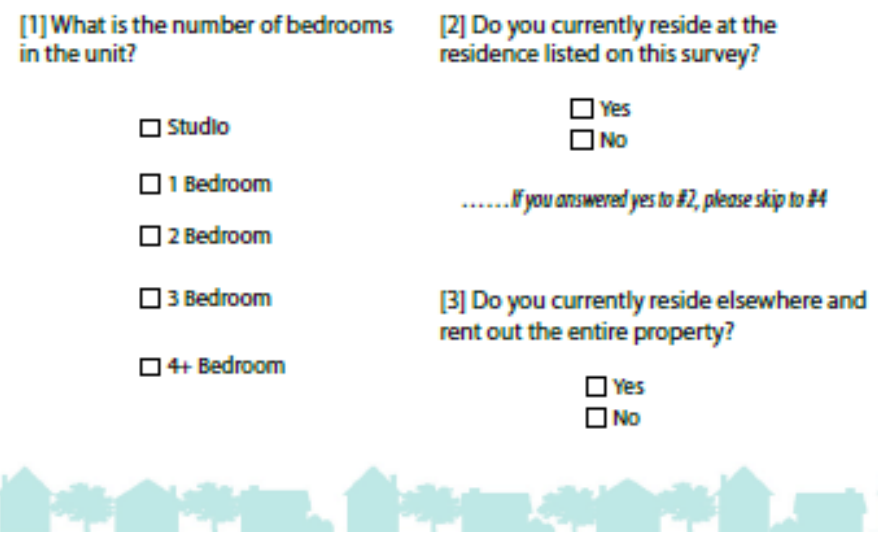

[1] What is the number of bedrooms

$\square$ Studio

$\square 1$ Bedroom
[2] Do you currently reside at the residence listed on this survey?

[4] What is the affordability of the unit?

\author{
$\square$ Extremely Low
}

$\square$ Very Low

$\square$ Low

$\square$ Moderate

UUnknown

Thank you for your time.
[1] What is the number of bedrooms in the unit?

$$
\begin{aligned}
& \square \text { Studlo } \\
& \square 1 \text { Bedroom } \\
& \square 2 \text { Bedroom } \\
& \square 3 \text { Bedroom } \\
& \square 4+\text { Bedroom }
\end{aligned}
$$

[2] How many people reside at the residence?
[3] What is the affordability of the unit?

$\square$ Extremely Low $\quad \square$ Moderate
$\square$ Very Low $\quad \square$ Unknown
$\square$ Low

[4] What are you currently being charged for rent?

\begin{tabular}{|c|c|}
\hline Feplesmption & Cox \\
\hline Fendescaption & $\cos$ \\
\hline
\end{tabular}

$\$$
[5] Are you currently being charged an HOA fee or any other fees?

$$
\begin{aligned}
& \square \text { Yes } \square \text { No } \square \text { Idon't know } \\
& \text { Ifyes, list:__ fellomintion } \$ \text { Cos }
\end{aligned}
$$

[6] Please attach a copy of your income certification for the address listed on this survey.

$\square$ I don't have a copy of the income certification

Thank you for your time.

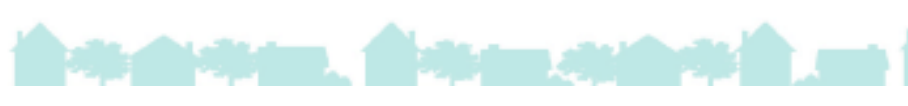

[1] What is the number of bedrooms in the unit?

$$
\begin{aligned}
& \square \text { Studlo } \\
& \square 1 \text { Bedroom } \\
& \square 2 \text { Bedroom } \\
& \square 3 \text { Bedroom } \\
& \square 4+\text { Bedroom }
\end{aligned}
$$

[2] How many people reside at the residence?
[3] What is the affordability of the unit?

$\square$ Extremely Low $\square$ Moderate
$\square$ Very Low $\quad \square$ Unknown

口Low

[4] What are you currently charging the tenant monthly for rent?
[5] Are you currently being charged an HOA fee or any other fees?

$\square$ Yes $\square$ No $\square$ Idon't know If yes, list:

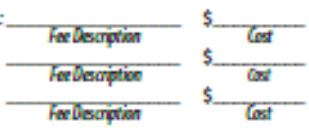

[6] Please attach a copy of the tenants' income certification for the address listed on this survey. $\square$ I don't have a copy of the
Income certification

person(s)

$$
\text { s }
$$$$
\text { Thank you for your time. }
$$ 


\section{Appendix D: AFFORDABLE HOUSING BROCHURE}
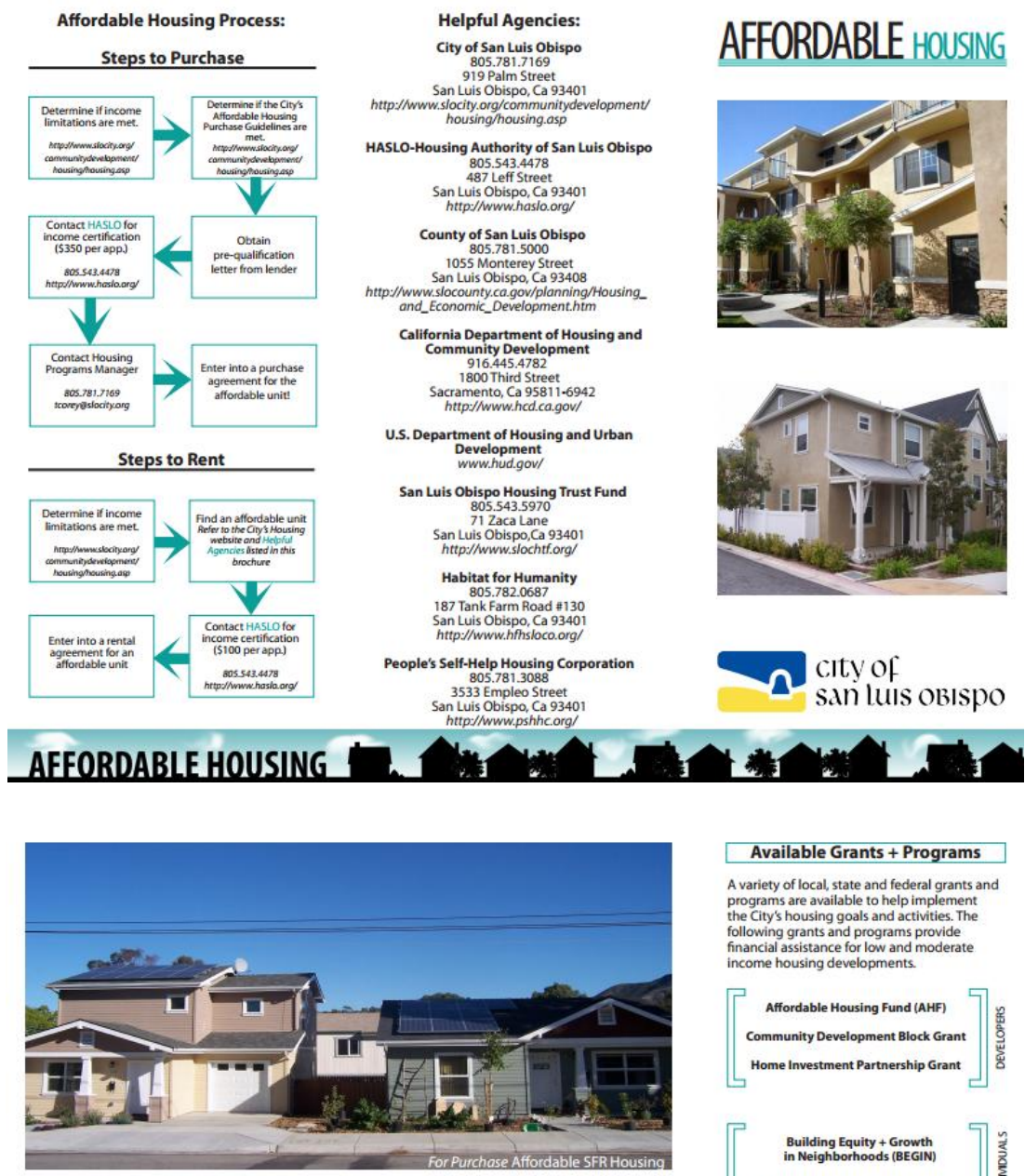

Available Grants + Programs

A variety of local, state and federal grants and programs are available to help implement
the City's housing goals and activities. The following grants and programs provide income housing developments.

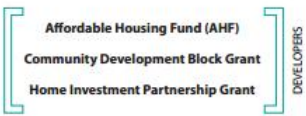

What is Affordable Housing? The generally accepted definition of affordability
is for a household to pay no more than $30 \%$ of monthly income to housing (Rent or Mortgage). The lack them from meeting their basic needs. This is why efforts to encourage and support the
construction of more affordable housing is vital.

Affordable Housing Standards The City of San Luis Obsipo publishes Affordable Housing Standards annually on April 1st. These per household that qualify for affordable housing. The standards also include maximum rent and sales prices for units within the City's Affordable housing standards visit the we a to hate slocity.org/communitydevelopment' slocity.org/communityding

Affordable Housing Incentives For Developers

The Affordable Housing Incentives are for developers interested in constructing affordable housing. These incentives are part of the City's

-Density Bonuses

-Impact and Development Fee Waivers - Direct City Financial Assistance - Exceptions to Subdivision and Property
Development Standards

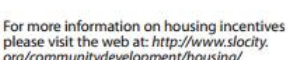
affordableincentives.asp

\section{AFFORDABIEHOUSING}
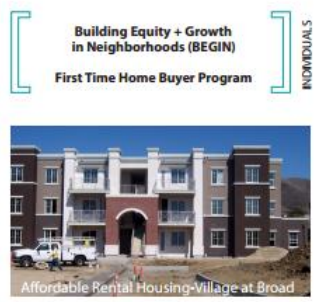

For More Information Contact: Tyler Corey-Housing Programs Manager

919 Palm Street
San Luis Obispo, CA. 93401-3249

tcoreyesoslocity.org $\mathbf{2}$
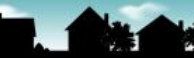


\section{Appendix E: AFFORDABLE HOUSING INVENTORY LIST}

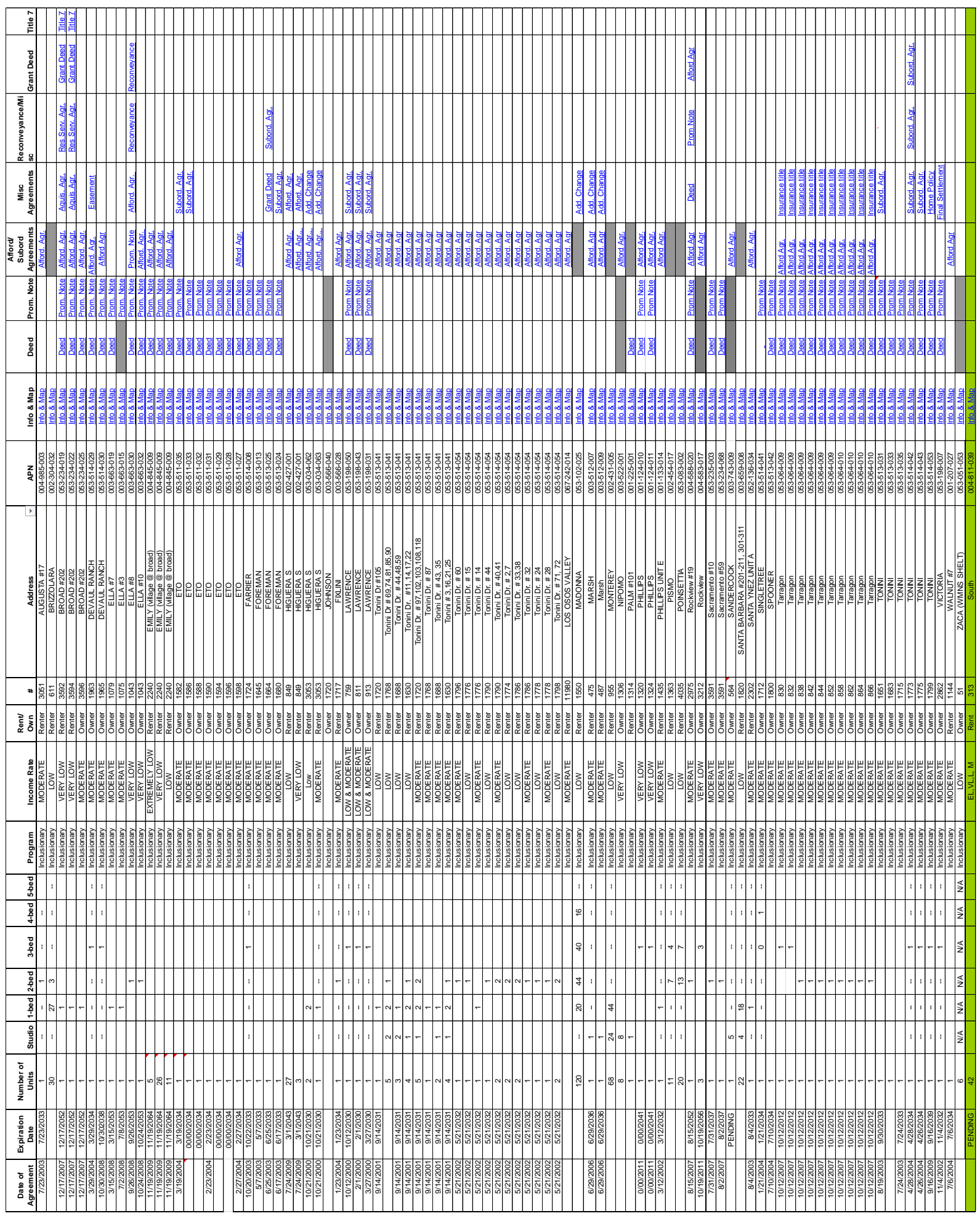




\section{Appendix F: CITY OF SANTA MONICA GREEN AFFORDABLE HOUSING CHECKLIST}

\section{GREEN AFFORDABLE HOUSING CHECKLIST}

\section{Purpose and Use of the Green Affordable Housing Checklist}

The City of Santa Monica Housing and Redevelopment Division strongly encourages the use of environmentally sensitive ("green") building materials and systems in affordable housing developments.

This checklist is intended to encourage developers to consider green building methods and practices in the earliest stages of project planning. On the checklist are a number of recommended green practices, including practices related to energy efficiency; landscaping; framing and carpentry; indoor air quality; and other building systems and materials. Keeping in mind the intended scope of each project, budgetary constraints, availability of materials, and other factors, our goal is that as many of these practices as possible be incorporated into each project.

It should be noted that many green building systems and materials are evolving and becoming increasingly available. Therefore, this checklist is a living document, to be updated as technology and construction practices change.

Costs

Some of these practices involve no additional costs. Others may involve marginally or significantly higher initial costs. Please do not dismiss some items just because they may cost more, as the City may be willing to fund the increased cost in the interest of promoting a healthy environment.

\section{Contractor Bid Packages}

If you do not have, or cannot obtain, current costs for certain items on the checklist, please include these as alternatives as part of the contractor bid package in order to determine the cost.

\section{Completing the Checklist}

Please complete this checklist to show which green building practices will be included in the project. If you do not intend to include certain practices, or if the practice is not applicable to the project, please provide an explanation on the checklist. Also, please indicate which items will be included as alternatives in the contractor bid package. To facilitate completion of the checklist, the City's Project Analyst is available to assist you.

\begin{tabular}{|c|c|c|c|c|c|c|}
\hline \multicolumn{7}{|c|}{$\begin{array}{c}\text { City of Santa Monica Housing and Redevelopment Division } \\
\text { - Green Affordable Housing Checklist - }\end{array}$} \\
\hline \multirow[b]{2}{*}{$\begin{array}{l}\text { Item and Santa Monica Green } \\
\text { Building Design and } \\
\text { Construction Guideline } \\
\text { (SMGBD\&CG) reference }\end{array}$} & \multirow[b]{2}{*}{ Description } & \multirow[b]{2}{*}{ Benefit } & \multicolumn{4}{|c|}{ Included in Project } \\
\hline & & & Yes & No & $\begin{array}{l}\text { Not Sure--Will } \\
\text { Include in Bid } \\
\text { Package to } \\
\text { Determine Cost }\end{array}$ & N/A \\
\hline \multicolumn{7}{|l|}{ Energy Efficiency } \\
\hline $\begin{array}{l}\text { Energy Efficient Lighting } \\
S M \text { GBD\&CG-ES2 }\end{array}$ & $\begin{array}{l}\text { Energy efficient exterior } \\
\text { lighting, such as high- } \\
\text { pressure sodium. Should } \\
\text { be appropriately sized for } \\
\text { the location. } \\
\text { Interior fluorescent bulbs } \\
\text { and (where practical and } \\
\text { appropriate) fixtures } \\
\text { produce light quantity and } \\
\text { quality that is comparable to } \\
\text { incandescents, while } \\
\text { expending less energy. }\end{array}$ & $\begin{array}{l}\text { Energy efficient lighting } \\
\text { reduces energy consumption } \\
\text { and lowers utility bills. One } \\
\text { compact florescent bulb will } \\
\text { pay itself back over ten times } \\
\text { over the course of its life } \\
\text { through reduced energy use. }\end{array}$ & & & & \\
\hline \multicolumn{7}{|c|}{ If included, please describe how the item will be used in the project. } \\
\hline \multicolumn{7}{|l|}{ If not included, please describe why. } \\
\hline $\begin{array}{l}\text { Resource Efficient Appliances } \\
\text { SM GBD\&CG-WS1 }\end{array}$ & $\begin{array}{l}\text { Refrigerators, water } \\
\text { heaters, stoves, } \\
\text { dishwashers, and washing } \\
\text { machines that are designed } \\
\text { to use less energy and } \\
\text { water. Most efficient } \\
\text { appliances qualify for } \\
\text { Energy Star designation. }\end{array}$ & $\begin{array}{l}\text { Appliances, particularly } \\
\text { refrigerators and water } \\
\text { heaters, are some of the major } \\
\text { sources of residential energy } \\
\text { use. Reducing energy and } \\
\text { water use lowers utility bills } \\
\text { while benefiting the } \\
\text { environment. }\end{array}$ & & & & \\
\hline \multicolumn{7}{|c|}{ If included, please describe how the item will be used in the project. } \\
\hline If not included, please describe wh & & & & & & \\
\hline
\end{tabular}




\begin{tabular}{|c|c|c|c|c|c|c|}
\hline \multicolumn{7}{|c|}{$\begin{array}{c}\text { City of Santa Monica Housing and Redevelopment Division } \\
\text { - Green Affordable Housing Checklist - }\end{array}$} \\
\hline \multirow[b]{2}{*}{$\begin{array}{l}\text { Item and Santa Monica Green } \\
\text { Building Design and } \\
\text { Construction Guideline } \\
\text { (SMGBD\&CG) reference }\end{array}$} & \multirow[b]{2}{*}{ Description } & \multirow[b]{2}{*}{ Benefit } & \multicolumn{4}{|c|}{ Included in Project } \\
\hline & & & Yes & No & \begin{tabular}{|l} 
Not Sure--Will \\
Include in Bid \\
Package to \\
Determine Cost \\
\end{tabular} & N/A \\
\hline $\begin{array}{l}\text { Combined Hydronic Heating } \\
\text { SM GBD\&CG-HSB }\end{array}$ & $\begin{array}{l}\text { This system uses hot water } \\
\text { from the water heater for } \\
\text { space heating. Applicable } \\
\text { for new construction and } \\
\text { major rehab only. }\end{array}$ & $\begin{array}{l}\text { Using the water heater for two } \\
\text { purposes uses energy more } \\
\text { efficiently. }\end{array}$ & & & & \\
\hline \multicolumn{7}{|c|}{ If included, please describe how the item will be used in the project. } \\
\hline \multicolumn{7}{|l|}{ If not included, please describe why. } \\
\hline \multicolumn{7}{|l|}{ Landscaping } \\
\hline $\begin{array}{l}\text { Low-Water Landscape } \\
\text { Designs } \\
\text { SM GBD\&CG-LA3 } \\
\text { See Zoning Ordinance } \\
\text { Section 9.04.010.04.110 Water } \\
\text { Conservation Landscaping }\end{array}$ & $\begin{array}{l}\text { Low-water landscape } \\
\text { designs, such as xeriscape, } \\
\text { reduce water use by } \\
\text { emphasizing native and/or } \\
\text { drought tolerant plants, } \\
\text { elimination of turf areas, } \\
\text { and minimizing } \\
\text { maintenance. }\end{array}$ & $\begin{array}{l}\text { Low-water designs reduce } \\
\text { water and maintenance bills } \\
\text { and impacts on local water } \\
\text { supply infrastructure. }\end{array}$ & & & & \\
\hline \multicolumn{7}{|c|}{ If included, please describe how the item will be used in the project. } \\
\hline
\end{tabular}

\begin{tabular}{|c|c|c|c|c|c|c|}
\hline \multicolumn{7}{|c|}{$\begin{array}{c}\text { City of Santa Monica Housing and Redevelopment Division } \\
\text { - Green Affordable Housing Checklist - }\end{array}$} \\
\hline \multirow[b]{2}{*}{$\begin{array}{l}\text { Item and Santa Monica Green } \\
\text { Building Design and } \\
\text { Construction Guideline } \\
\text { (SMGBD\&CG) reference }\end{array}$} & \multirow[b]{2}{*}{ Description } & \multirow[b]{2}{*}{ Benefit } & \multicolumn{4}{|c|}{ Included in Project } \\
\hline & & & Yes & No & $\begin{array}{l}\text { Not Sure--Will } \\
\text { Include in Bid } \\
\text { Package to } \\
\text { Determine Cost }\end{array}$ & N/A \\
\hline $\begin{array}{l}\text { Water-Efficient Irrigation } \\
S M G B D \& C G-L A b\end{array}$ & $\begin{array}{l}\text { Water efficient systems, } \\
\text { such as drip irrigation, place } \\
\text { the correct amount of water } \\
\text { directly at the base of each } \\
\text { plant thus reducing water } \\
\text { use and waste from } \\
\text { overwatering. } \\
\end{array}$ & $\begin{array}{l}\text { Water efficient systems help } \\
\text { plant growth and overall health } \\
\text { by eliminating over watering or } \\
\text { excessive drying. They also } \\
\text { lower water bills and reduce } \\
\text { impacts on water supply } \\
\text { infrastructure. }\end{array}$ & & & & \\
\hline \multicolumn{7}{|c|}{ If included, please describe how the item will be used in the project. } \\
\hline \multicolumn{7}{|l|}{ If not included, please describe why. } \\
\hline \multicolumn{7}{|c|}{ Engineered Lumber and Wood Alternatives } \\
\hline $\begin{array}{l}\text { Oriented Strand Board (OSB) } \\
S M G B D \& C G M A 3\end{array}$ & $\begin{array}{l}\text { OSB is an alternative to } \\
\text { plywood for sheathing, } \\
\text { flooring, and roofing. }\end{array}$ & $\begin{array}{l}\text { Plywood requires the use of } \\
\text { large-size, typically old growth } \\
\text { trees. OSB is made from } \\
\text { small pieces of wood, thus } \\
\text { eliminating or reducing } \\
\text { impacts to forests. }\end{array}$ & & & & \\
\hline \multicolumn{7}{|c|}{ If included, please describe how the item will be used in the project. } \\
\hline \multicolumn{7}{|l|}{ If not included, please describe why. } \\
\hline $\begin{array}{l}\text { Wood I-Beam } \\
\text { SM GBD\&CG-MA3 }\end{array}$ & $\begin{array}{l}\text { Wood l-Beams are an } \\
\text { alternative to } 2 \times 6 \mathrm{~s} \text { or } 2 \times 8 \mathrm{~s} \\
\text { used for floor and roof } \\
\text { joists. }\end{array}$ & $\begin{array}{l}\text { Wood I-Beams are engineered } \\
\text { to use less wood to perform } \\
\text { the same function and are } \\
\text { often straighter, thus } \\
\text { minimizing wood waste. }\end{array}$ & & & & \\
\hline
\end{tabular}




\begin{tabular}{|c|c|c|c|c|c|c|}
\hline & $\begin{array}{r}\text { City of Santa Monica Hc} \\
\text { - Green Affor }\end{array}$ & $\begin{array}{l}\text { using and Redevelopmen } \\
\text { lable Housing Checklist - }\end{array}$ & Divis & & & \\
\hline & & & Inclu & ed in & Project & \\
\hline $\begin{array}{l}\text { Item and Santa Monica Green } \\
\text { Building Design and } \\
\text { Construction Guideline } \\
\text { (SMGBD\&CG) reference }\end{array}$ & Description & Benefit & Yes & No & $\begin{array}{l}\text { Not Sure--Will } \\
\text { Include in Bid } \\
\text { Package to } \\
\text { Determine Cost }\end{array}$ & N/A \\
\hline If not included, please describe wh & & & & & & \\
\hline $\begin{array}{l}\text { Laminated Wood Fiber } \\
\text { Products } \\
\text { SM GBD\&CG-MA3 }\end{array}$ & $\begin{array}{l}\text { Gluelam, parlam, microlam, } \\
\text { etc. are alternatives to large } \\
\text { dimension lumber for } \\
\text { trusses, beams, and } \\
\text { headers. }\end{array}$ & $\begin{array}{l}\text { Laminate products provide the } \\
\text { same strength while } \\
\text { eliminating the need to use } \\
\text { large-dimension lumber from } \\
\text { old-growth sources. }\end{array}$ & & & & \\
\hline If included, please describe how th & e item will be used in the proje & & & & & \\
\hline If not included, please describe wh & & & & & & \\
\hline $\begin{array}{l}\text { Certified Wood } \\
\text { SM GBD\&CG-MA6 }\end{array}$ & $\begin{array}{l}\text { Certified wood is used like } \\
\text { conventional lumber for } \\
\text { framing, etc. Based on } \\
2001 \text { availability, may be } \\
\text { appropriate for new } \\
\text { construction and major } \\
\text { rehab projects only. }\end{array}$ & $\begin{array}{l}\text { Wood certified by the Forest } \\
\text { Stewardship Council has been } \\
\text { monitored from the forest to } \\
\text { the local supplier to ensure } \\
\text { that the wood is harvested, } \\
\text { milled, and delivered under } \\
\text { environmentally, and socially } \\
\text { responsible conditions. }\end{array}$ & & & & \\
\hline If included, please describe how th & e item will be used in the proje & & & & & \\
\hline If not included, please describe wh & & & & & & \\
\hline
\end{tabular}

\begin{tabular}{|c|c|c|c|c|c|c|}
\hline \multicolumn{7}{|c|}{$\begin{array}{c}\text { City of Santa Monica Housing and Redevelopment Division } \\
\text { - Green Affordable Housing Checklist - }\end{array}$} \\
\hline \multirow[b]{2}{*}{$\begin{array}{l}\text { Item and Santa Monica Green } \\
\text { Building Design and } \\
\text { Construction Guideline } \\
\text { (SMGBD\&CG) reference }\end{array}$} & \multirow[b]{2}{*}{ Description } & \multirow[b]{2}{*}{ Benefit } & \multicolumn{4}{|c|}{ Included in Project } \\
\hline & & & Yes & No & \begin{tabular}{|l} 
Not Sure--Will \\
Include in Bid \\
Package to \\
Determine Cost
\end{tabular} & N/A \\
\hline $\begin{array}{l}\text { Plastic Lumber } \\
\text { SM GBD\&CG-Mab } \\
\text { SM GBD\&CG-LA7 }\end{array}$ & $\begin{array}{l}\text { Plastic lumber is made from } \\
\text { recycled plastic products. } \\
\text { It can be used as an } \\
\text { alternative to wood in non- } \\
\text { structural applications such } \\
\text { as decking and fencing, } \\
\text { depending on field } \\
\text { conditions. }\end{array}$ & $\begin{array}{l}\text { Plastic lumber is highly } \\
\text { durable and is not susceptible } \\
\text { to rot or termite damage. It is } \\
\text { also an excellent use of } \\
\text { recycled plastics. }\end{array}$ & & & & \\
\hline \multicolumn{7}{|c|}{ If included, please describe how the item will be used in the project. } \\
\hline \multicolumn{7}{|l|}{ If not included, please describe why. } \\
\hline $\begin{array}{l}\text { Fiber-Cement Siding } \\
\text { SM GBD\&CG-Mab } \\
\text { SM GBD\&CG-MA4 }\end{array}$ & $\begin{array}{l}\text { Fiber cement siding can be } \\
\text { used as an alternative to } \\
\text { redwood or other types of } \\
\text { siding. }\end{array}$ & $\begin{array}{l}\text { Fiber cement siding is not } \\
\text { susceptible to rot or termites } \\
\text { and is fire resistant. }\end{array}$ & & & & \\
\hline \multicolumn{7}{|c|}{ If included, please describe how the item will be used in the project. } \\
\hline If not included, please describe why & & & & & & \\
\hline
\end{tabular}




\section{Appendix G-1: WORD CLOUDS (Overall)}

If you could change 3 things about your home what would those be?

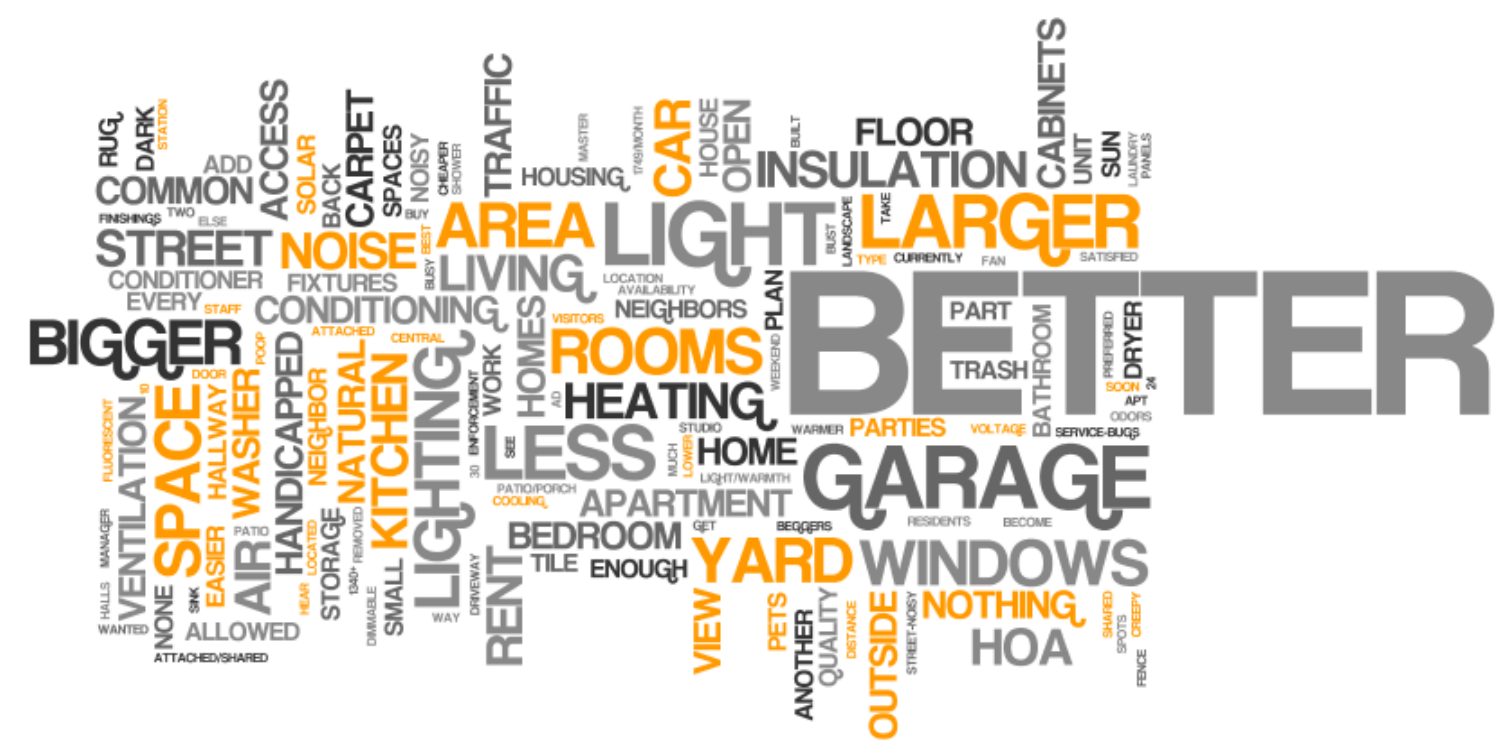

List the features of your home you are most satisfied with?

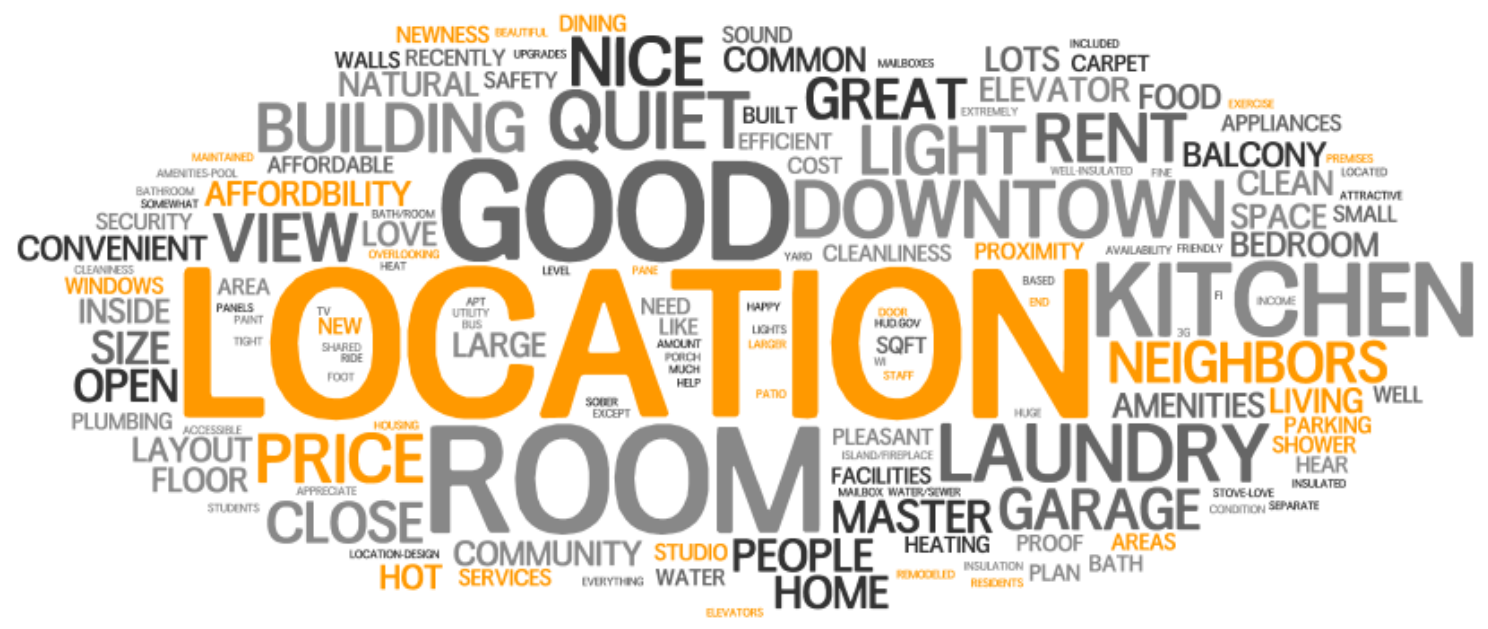




\section{Appendix G-2: WORD CLOUDS (Senior)}

If you could change 3 things about your home what would those be?

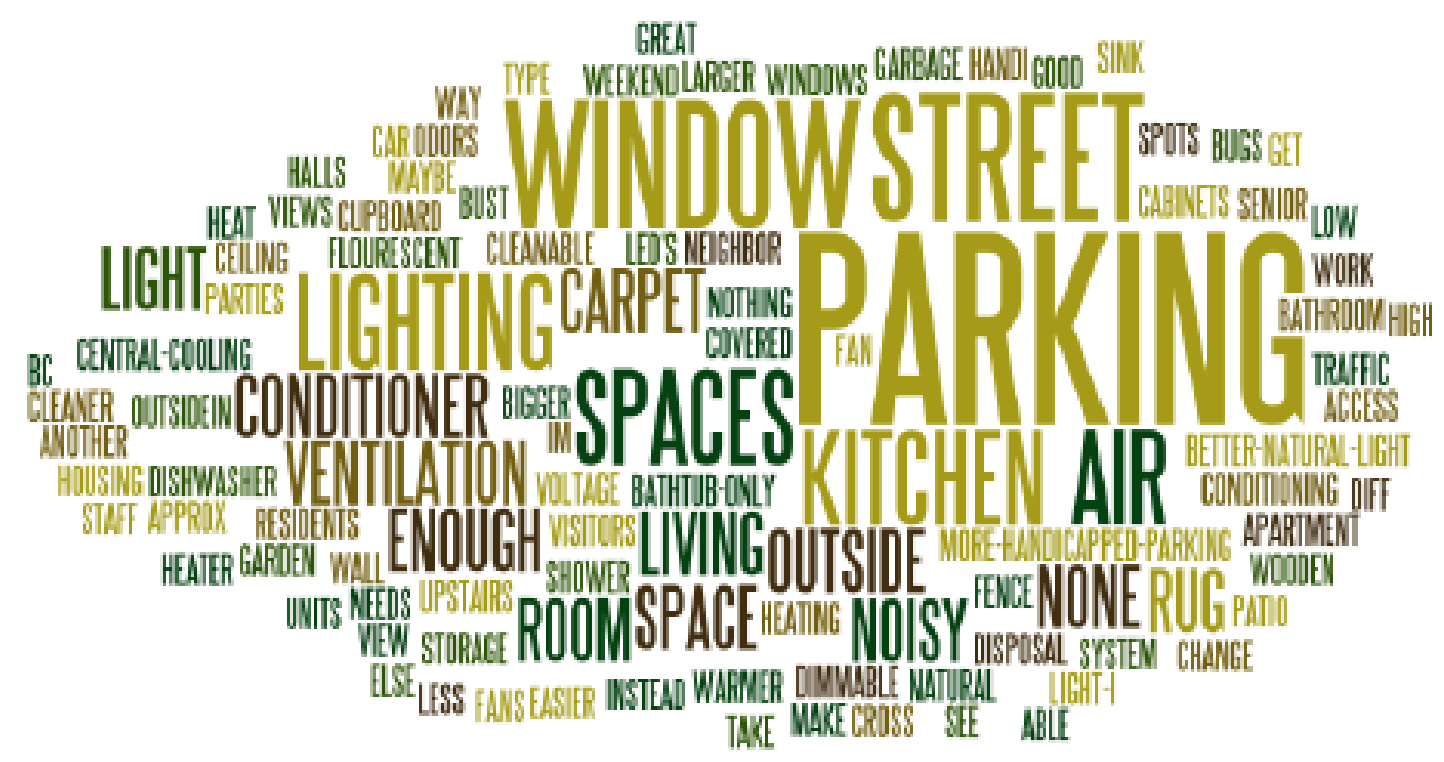

List the features of your home you are most satisfied with?

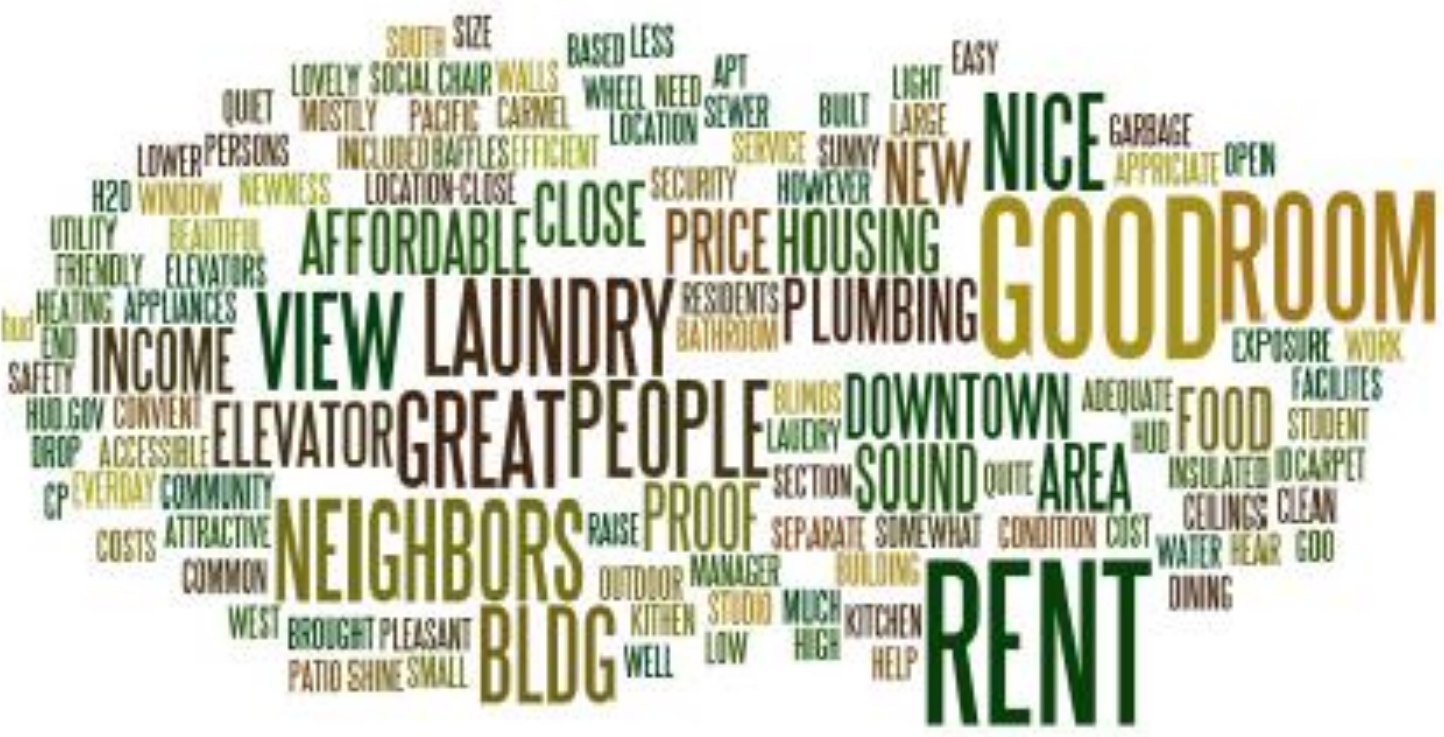




\section{Appendix G-3: WORD CLOUDS (Owner)}

If you could change 3 things about your home what would those be?

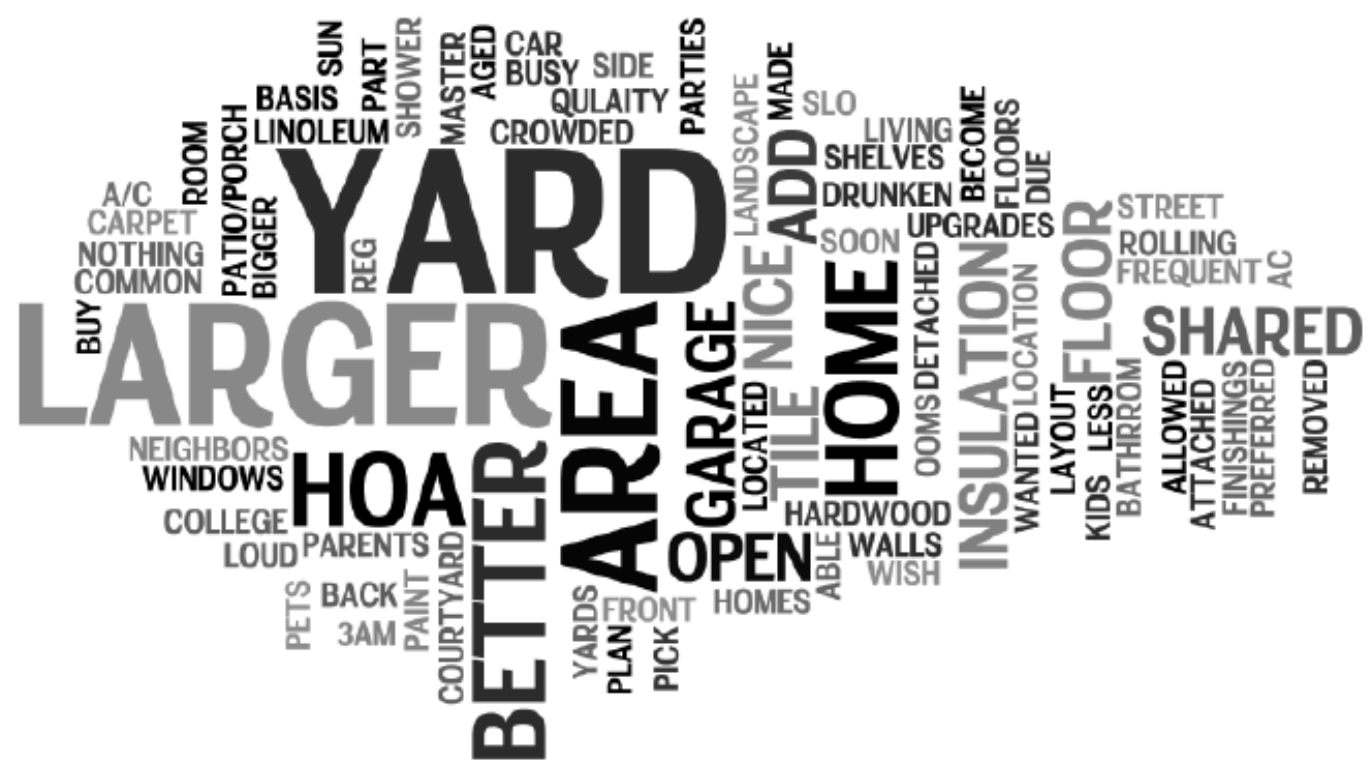

List the features of your home you are most satisfied with?

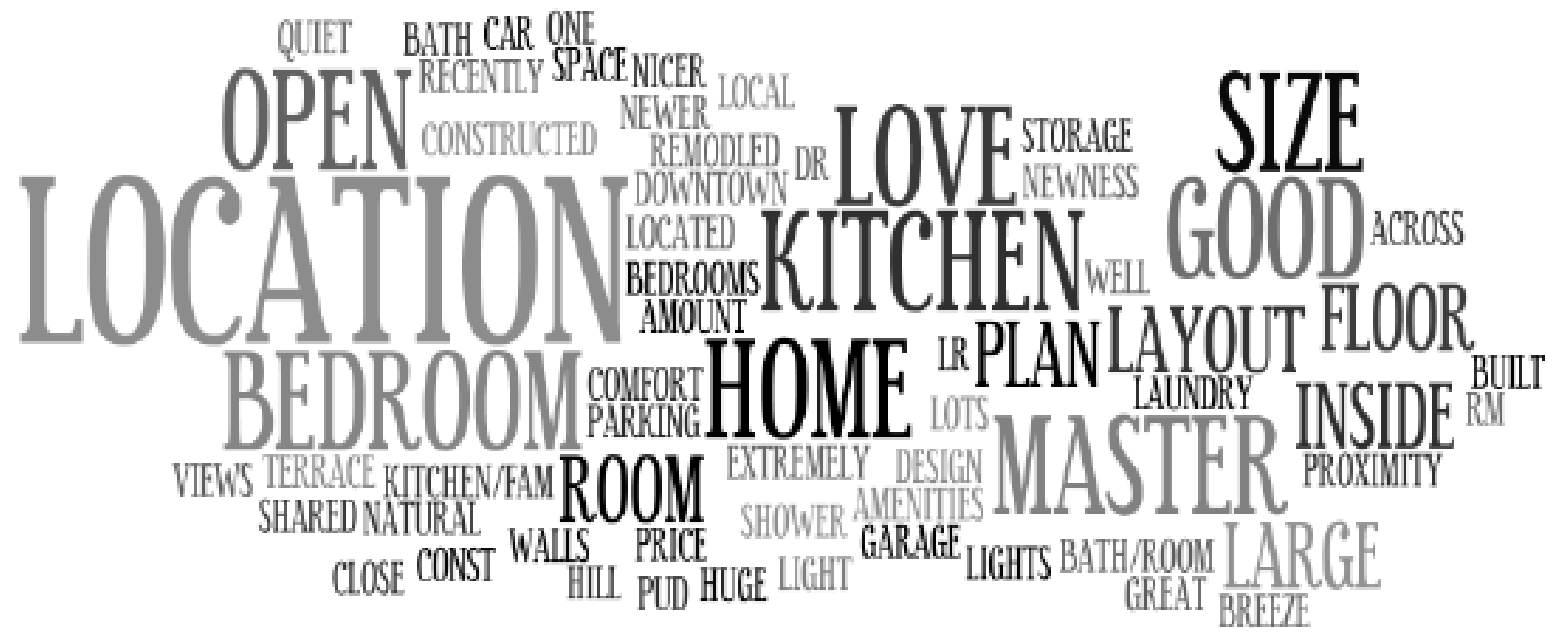




\section{Appendix G-4: WORD CLOUDS (Renter)}

If you could change 3 things about your home what would those be?

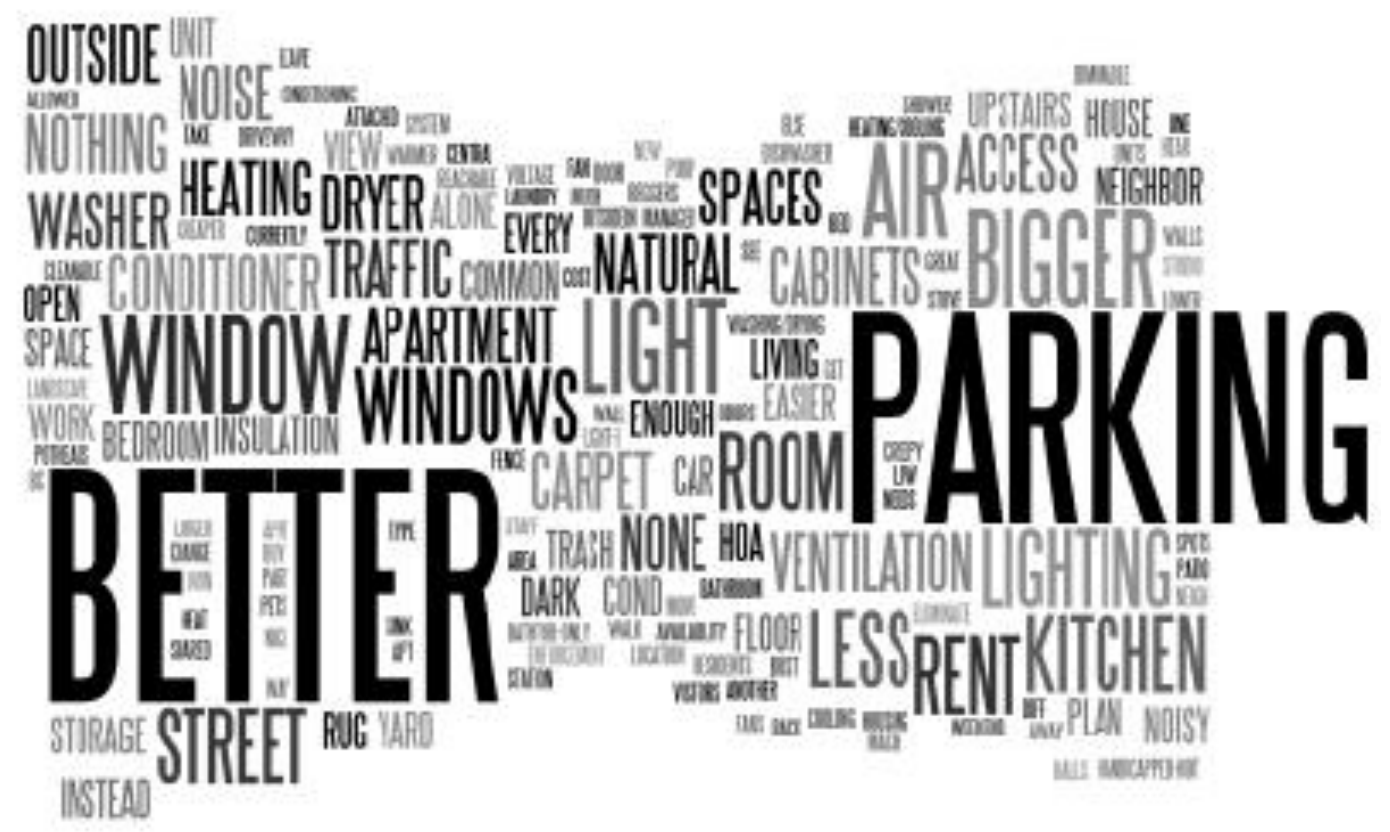

List the features of your home you are most satisfied with?

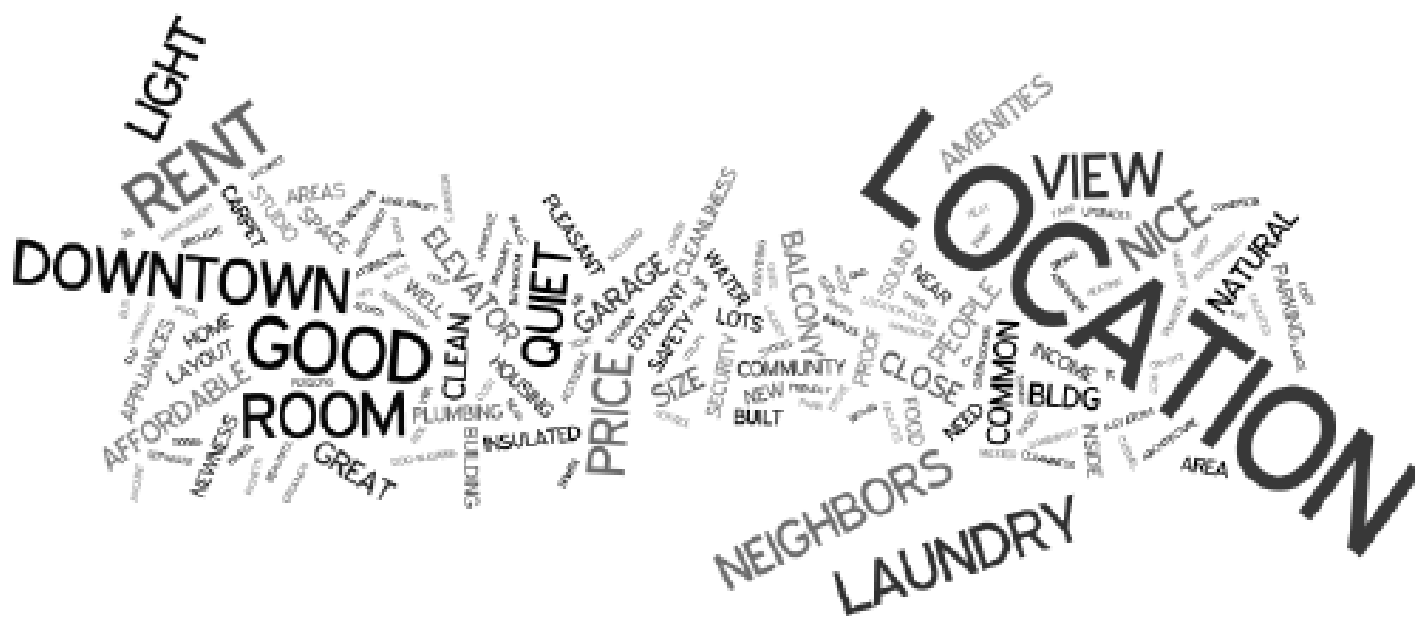




\section{ENTRADA RANCH}

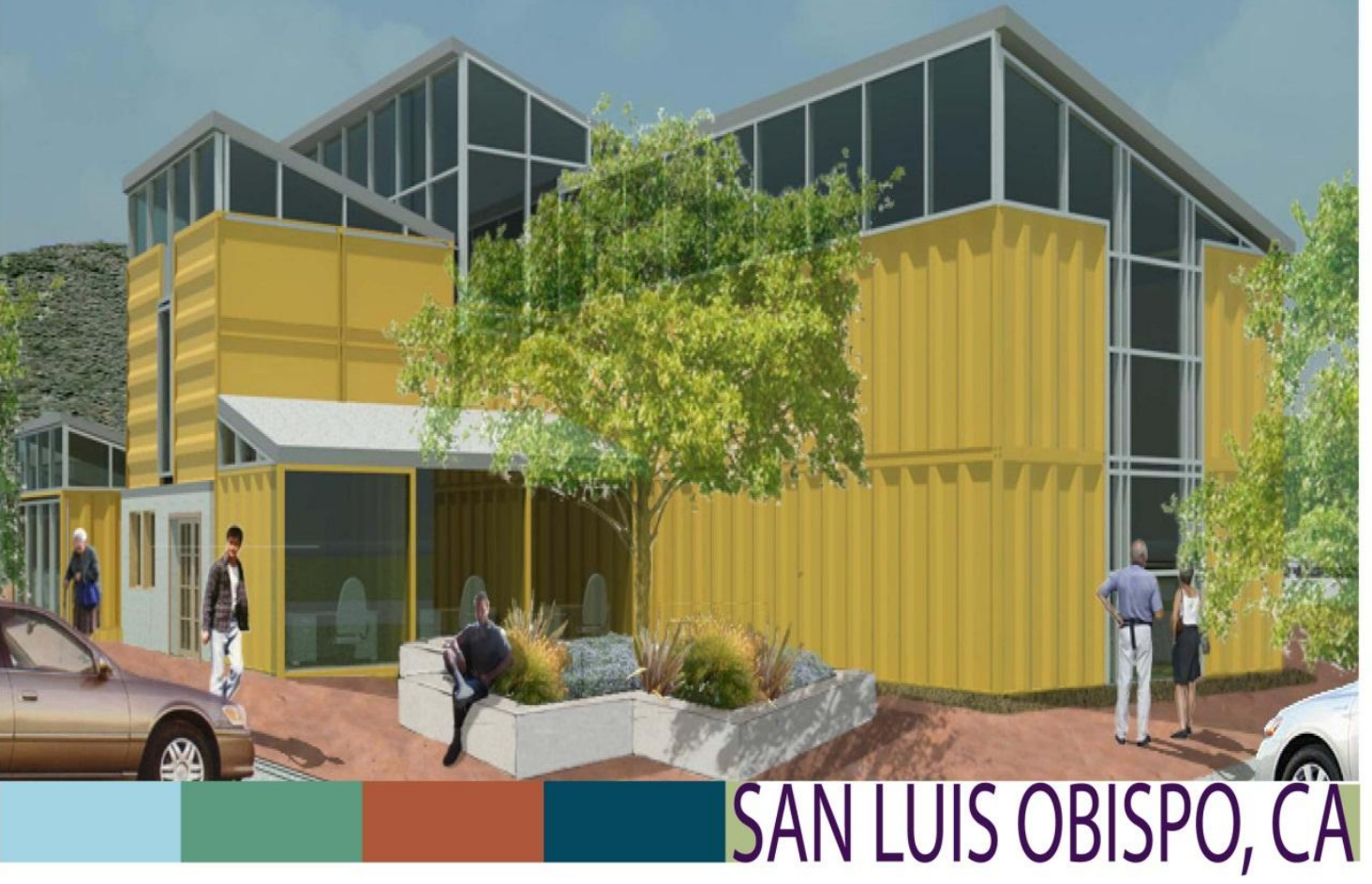

\section{Bank of America Low-Income Housing Challenge 2011}

Poly Collaborative Housing

California Polytechnic State University 


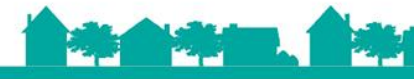




\section{ENTRADA RANCH}

\section{Acknowledgments}

The Bank of America Low-Income Housing Challenge brings an interdisciplinary team of students together to work on a realistic development. In the process, invaluable knowledge and experience is exchanged between teammates. However, the success of the project would not have been possible without the strong community support received from professors, professionals, and advisors always willing to offer support, critiques, and time throughout the project process. We thank all of our supporters for their ongoing encouragement. We would also like to thank Bank of America Merrill Lynch for facilitating this competition.

Clint Pearce

R. Thomas Jones

Hemalata C. Dandekar

Umut Toker

Jun Hyunh Kim

Gary Clay

Phillip Barlow

Scott Kelting

Mike Montoya

Tom Fowler

Walker Wells

Robert A. Hill

Stephen Rigor

Dana Lilley

Phil Dunsmore

Kim Murry

Tyler Corey

Tina Slusher

Shelly Stanwyck

Sheridan Bohlken

Neil Havlik

Ken Trigueiro

Joan Sullivan

James Ostrom

Jim Rendler

Maria Joyce Maynard

Lori Saito

Clay Appleton

M. Dolores Berber-Jimenez

David Headrick

Tim Banducci

Kim Mondelli
Developer, Madonna Enterprises

Dean, College of Architecture and Environmental Design, Cal Poly San Luis Obispo

City \& Regional Planning Department Head, Cal Poly San Luis Obispo

City \& Regional Planning Professor, Cal Poly San Luis Obispo

Landscape Architecture Professor, Cal Poly San Luis Obispo

Landscape Architecture Professor, Cal Poly San Luis Obispo

Construction Management Professor, Cal Poly San Luis Obispo

Construction Management Professor, Cal Poly San Luis Obispo

Construction Management Professor, Cal Poly San Luis Obispo

Architecture Professor, Cal Poly San Luis Obispo

Director of Green Urbanism, Global Green USA

Executive Director, The Land Conservancy

Arris Studio Architects

Supervising Planner, San Luis Obispo County

Long Range Planning, City of San Luis Obispo

Long Range Planning, City of San Luis Obispo

Housing Programs, City of San Luis Obispo

Permit Coordinator, City of San Luis Obispo

Parks \& Recreation Director, City of San Luis Obispo

Parks \& Recreation, City of San Luis Obispo

Natural Resources Manager, City of San Luis Obispo

People's Self Help Housing and Housing Authority

San Luis Obispo County Historical Society

Forest City Development- High Def Design

ForTheFuture Housing

Bank of America Merrill Lynch, Community Development Banking

Wells Fargo, Community Lending and Investment

Mission Community Bank

Department Chair, Cal Poly Liberal Studies

Cal Poly Organic Farm

California-West, Inc., Real Estate Management

CSG Advisors 
For Dan Panetta.

May your memory be eternal!

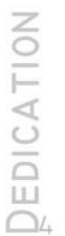

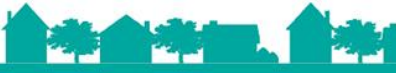




\section{ENTRADA RANCH}

\section{Table of Contents}

Acknowledgments

Project Introduction

Executive Summary

\section{The Market}

Needs Analysis...

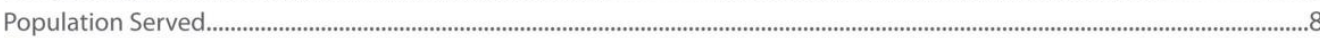

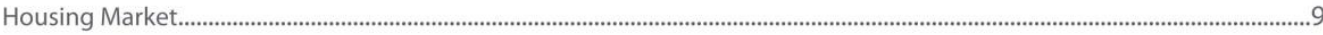

\section{The Site}

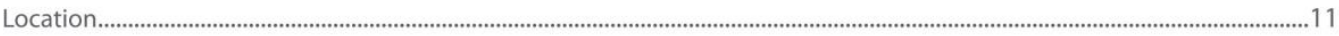

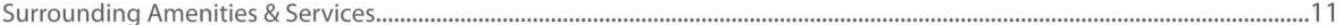

Existing Site Conditions...........................................................................................................................................................13

Environmental Review and Mitigation …………………......................................................................................................13

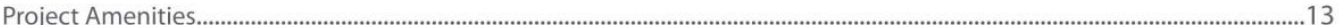

\section{Entitlements}

Regulatory Context.

\section{Design Concept}

Design Overview

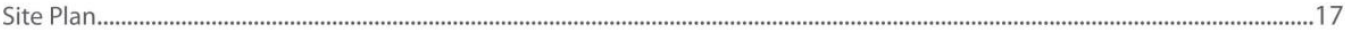

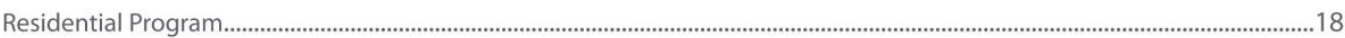

Floor Plans..................................................................................................................................................................................18, 20

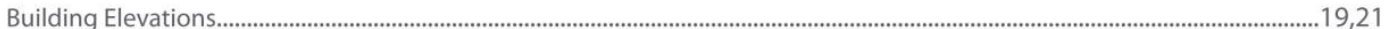

Building Perspectives......................................................................................................................................................................19, 21, 22

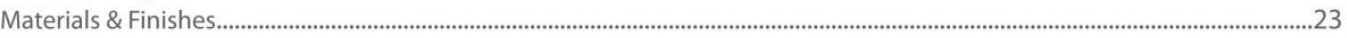

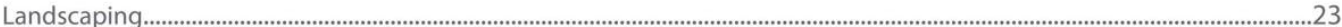

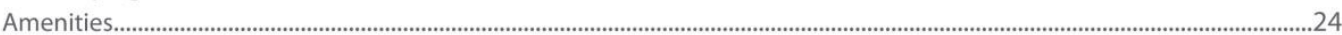

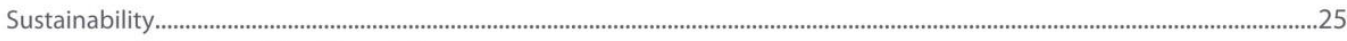

LEED for Neighborhood Development...............................................................................................................................................26

\section{Resident Services and Community Engagement}

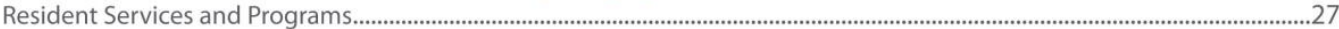

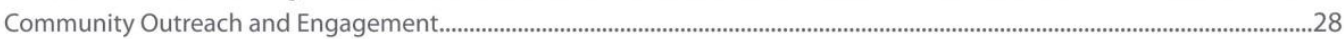

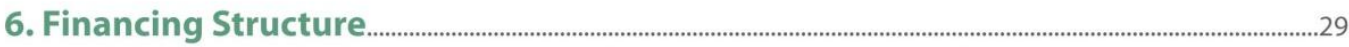

\section{Development Timeline}

Development Schedule..........................................................................................................................................................................38

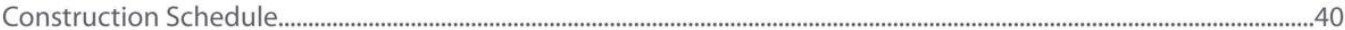

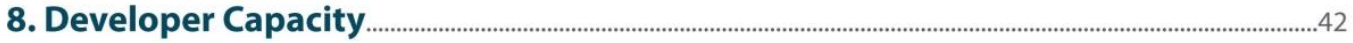

9. Work Product Disclosure \& Meet the Team.................................................................................................42, 43

10. Appendix 
Project Overview

Developer

Madonna Enterprises

\section{Location}

12615 Los Osos Valley Road,

San Luis Obispo, CA 93405

Total Site Acreage

11.6 Developable

Development Cost

TOTAL: $\$ 23,769,486$

\section{Key Financing Sources}

Construction \& Permanent Bond

San Luis Obispo County Housing Trust Fund

CA HCD Predevelopment Loan Program

Community Development Block Grant

HOME Investment Partnership

City of San Luis Obispo Affordable Housing Fund

4\% Federal Low Income Tax Credits

Sale of Single Family Lots

Sale of Commercial Lots

Developer Contribution
Unit Type

Rental

$100 \%$ Affordable

Total Units

135 Apartments \& Townhomes

Unit Breakdown

16 Studios

32 One Bedroom Units

44 Two Bedroom Units

27 Three Bedroom Flats

16 Three Bedroom Townhomes

Target Population

Low-wage-earning families

Amenities

Community Center

Wetlands

Trail Access

Healthy Living

Green Design Strategies

Woonerf Strategies

Community Gardens

Historic Reuse

Proximity to Services 


\section{Executive Summary}

The City of San Luis Obispo (SLO) is located in the heart of California's Central Coast and is home to approximately 45,000 residents. The population is composed of college students, retirees, and a professional workforce employed by governmental offices and institutions. This mix, combined with the City's long standing slow-growth policy, has made for a critical and chronic shortage of housing available to people of lower and moderate incomes.

The Poly Housing Collaborative (PHC), in partnership with Madonna Enterprises, proposes this innovative project to improve the affordable housing need with a mixed-use, residential and commercial project strategically located on a site within close proximity to existing and future jobs, services and amenities. The project will address the local and regional housing needs by providing 135 affordable units which includes: studios, one, two and three bedroom apartments and three bedroom townhomes on 11.6 developable acres.

The site has potential for creating successful affordable housing because:

- The City of San Luis Obispo has already earmarked this location in its General Plan Housing Element for acquisition and potential housing development

- It has a developer and property owner with a longstanding history of investments in the region

- It is close to services offered by both the public and private sectors

- There are a variety of well-established open space and recreational areas adjacent to the site

The natural features of the site include wetlands, creeks, trails and scenic views of the beautiful San Luis Obispo hills. These make the site conducive to successful affordable rental units. These features also make the case for both commercial feasibility and are attractive for potential development. The Project site is challenging because of its proximity to wetlands. However, PHC has worked with the Land Conservancy to fulfill proper impact mitigations, preservation, and to meet all regulatory requirements.
PHC proposes to develop Entrada Ranch, a sustainable, walkable, mixed-use and affordable community that enhances and diversifies the available housing stock in SLO. The project includes a substantial amount of low, very-low and extremely-low income housing units that are designed to receive cross-subsidy from the sale of undeveloped commercial and residential lots. Madonna Enterprises, our developer partner and owner of the site, supports our design solution which incorporates amenities, sustainable design, minimizes lifecycle energy consumption, facilitates healthy lifestyles and utilizes the surrounding natural landscape. By providing additional housing units at higher densities, PHC will support a local workforce that currently cannot afford to live within the City.

The project goals include:

- Creation of a development that is focused on healthy living practices

- Creation of a safe and enjoyable environment for families with access to amenities both on and off-site

- Implementation of sustainable design solutions, including LEED for Neighborhood Development certification

- Creation of an interactive and walkable community that will reduce residents' commute to work

- Establishment of a financially viable development

The Entrada Ranch project provides a valuable benefit for the San Luis Obispo community by offering a much needed supply of affordable housing in an innovative and environmentally friendly atmosphere that is close to job opportunities and amenities. 


\section{The Market}

\section{Needs Analysis}

The need for more affordable housing in San Luis Obispo is pressing. San Luis Obispo contains the largest concentration of jobs in the County. During the work week, the City's population increases from 45,000 to an estimated 70,000 persons (SLO 2010 Housing Element), and a portion of the commuting population would readily become residents if there was a greater supply of affordable housing. Due to the City's higher housing costs compared to nearby cities many must live elsewhere. Figure 1.1 compares San Luis Obispo with other cities in the county for percent of renters paying more than 30 percent of their income on housing according to the American Community Survey's 5-Year Estimates. The figure shows that 74 percent of renters in San Luis Obispo pay more than 30 percent of their income on housing costs, the highest percent in the county. Providing more affordable housing within the City will reduce the number of commuting workers and lower vehicle miles traveled. This, in turn, reduces emissions and helps the City meet the reduction goals set forth in the City's Climate Action Plan.

The lack of affordable housing might also contribute to the growing homeless population in the last few years. Since 2007 the number of homeless people in the county jumped from 2,400 to 4,000 with the number one reason cited being the inability to pay rent (2010 Enumeration Report). Rent costs are inflated within city limits because of its desirable location and landlords charging higher rents for individual rooms and units due to constant demand for housing by local college students. The City of San Luis Obispo has a responsibility, as well as the available land, to meet a growing need for more affordable housing.

\begin{tabular}{|c|c|}
\hline \multicolumn{2}{|c|}{ San Luis Obispo County } \\
\hline City & $\begin{array}{l}\text { Percent renters paying more than } \\
30 \text { percent of income }\end{array}$ \\
\hline San Luis Obispo & $74 \%$ \\
\hline Pismo Beach & $57 \%$ \\
\hline Paso Robles & $54 \%$ \\
\hline Atascadero & $53 \%$ \\
\hline Arroyo Grande & $51 \%$ \\
\hline
\end{tabular}

According to the U.S. Department of Housing and Urban Development (HUD) standards, households are rent-burdened if they pay more than 30 percent of annual income on rent and severely rent-burdened if they pay more than 50 percent. Figure 1.2 shows what is considered the maximum affordable rent based on income group and unit type. Currently, few rental units in the City of San Luis Obispo meet these price points.

Based on the Maximum Monthly Rent Affordability Standards described in Figure 1.2, the San Luis Obispo Council of Governments (SLOCOG) has allocated each city's fair share of affordable housing units for 2007-2014 to be 1,589 units as shown in Figure 1.3.

Poly Housing Collaborative's intention is to serve a majority of low-income individuals and families. Entrada Ranch helps fulfill part of the need for affordable housing based on workers' incomes and focuses on the need as a result of an increase in low-wage jobs. The average retail worker in San Luis Obispo earns approximately $\$ 9 /$ hour providing approximately $\$ 18,000$ annual income working a 40-hour work week. As Figure 1.4 indicates, based on this income level, the employee would fit the profile of someone in need of affordable housing.

\section{Population Served}

The Entrada Ranch project aims to serve the diverse population that is currently working within San Luis Obispo by increasing the amount of available affordable housing units. This population includes low income families and individuals. The development specifically targets the employees of the Irish Hills Plaza and other nearby businesses. It is anticipated that the Prefumo Creek Commons development, anchored by Target and currently under construction across the street from Entrada Ranch, will create over 250 jobs. The majority of employees at Irish Hills Plaza and the upcoming Perfumo Creek Commons development are paid salaries that would qualify them for affordable housing. 
ENTRADA RANCH

\begin{tabular}{|c|c|c|c|c|c|}
\hline \multicolumn{6}{|c|}{ San Luis Obispo 2010 Maximum Monthly Rent Affordability Standards } \\
\hline \multirow[t]{2}{*}{ Income Group } & \multicolumn{5}{|c|}{ Dwelling Size } \\
\hline & Studio & $1 \mathrm{BR}$ & $2 B R$ & $3 B R$ & $4 \mathrm{BR}$ \\
\hline Extremely Low & $\$ 381$ & $\$ 435$ & $\$ 489$ & $\$ 544$ & $\$ 587$ \\
\hline Very Low & $\$ 634$ & $\$ 725$ & $\$ 816$ & $\$ 906$ & $\$ 979$ \\
\hline Lower & $\$ 761$ & $\$ 870$ & $\$ 979$ & $\$ 1,131$ & $\$ 1,262$ \\
\hline Moderate & $\$ 1,057$ & $\$ 1,208$ & $\$ 1,359$ & $\$ 1,510$ & $\$ 1,631$ \\
\hline
\end{tabular}

\begin{tabular}{|l|c|c|c|}
\hline \multicolumn{3}{|l|}{ Regional Housing Need Allocation } \\
\hline $\begin{array}{l}\text { Income Category (\% of } \\
\text { County Median Income) }\end{array}$ & SFH & MFH & Total \\
\hline Extremely Low $(<30 \%)$ & 0 & 185 & 185 \\
\hline Very Low (30-50\%) & 0 & 185 & 185 \\
\hline Low (51-80\%) & 104 & 155 & 259 \\
\hline Moderate (81-120\%) & 118 & 177 & 295 \\
\hline Above Moderate (>120\%) & 266 & 399 & 665 \\
\hline TOTAL UNITS & $\mathbf{4 8 8}$ & $\mathbf{1 , 1 0 1}$ & $\mathbf{1 , 5 8 9}$ \\
\hline
\end{tabular}

Figure 1.3 City of San Luis Obispo Housing Need, Source: City of San Luis Obispo General Plan

\begin{tabular}{|l|c|c|c|c|c|c|c|}
\hline Income Group & \multicolumn{2}{|c|}{ Number of Persons in Household } & \multicolumn{4}{l|}{ ( } \\
\hline & 1 & 2 & 3 & 4 & 5 & 6 & 7 \\
\hline Extremely Low & 15,250 & 17,400 & 19,600 & 21,750 & 23,500 & 25,250 & 27,000 \\
\hline Very Low & 25,400 & 29,000 & 32,650 & 36,250 & 39,150 & 42,050 & 44,950 \\
\hline Lower & 40,600 & 46,400 & 52,200 & 58,000 & 62,650 & 67,300 & 71,950 \\
\hline Median & 50,750 & 58,000 & 65,250 & 72,500 & 78,300 & 84,100 & 89,900 \\
\hline Moderate & 60,900 & 69,600 & 78,300 & 87,000 & 93,950 & 100,900 & 107,900 \\
\hline
\end{tabular}

Figure 1.4 San Luis Obispo Maximum Income for Affordable Income Groups by Size of Household, Source: City of San Luis Obispo Affordable Housing Standards

\section{Housing Market}

The total number of households in SLO is approximately 20,222 , with an area median income of $\$ 39,827$ (CA Department of Finance, 2008). The available stock of housing units is approximately $8,322,42.4 \%$ of which are owneroccupied and 11,305 , or $57.6 \%$, are renter-occupied. The high percentage of renter occupied units is mostly attributed to the number of college students residing in the City. As of May 2009, there are 804 affordable housing units in the City. A summary of the existing affordability levels, term of affordability, and housing types are shown in Figure 1.5.

Along with the 804 affordable housing units that exist in SLO, there are many projects in the pipeline that were approved, are under construction, or were built since the most recent
Housing Element Update for the City's General Plan. Of the 1,589 housing units allocated to the City by SLOCOG from January 2010 to December 2014, 1,033 have met and exceeded the need for above moderate income housing units. However, there is still a need for 678 affordable units (moderate, low, very low and extremely-low).

According to the City of San Luis Obispo's General Plan, the cost of housing in San Luis Obispo has risen sharply in recent years while average household incomes have either slowly risen or remained steady. As a result, in 2008, approximately one half of households could afford a median-priced home based on their annual income. The median sale price for a single family home in San Luis Obispo was $\$ 454,000$ through 
February 2011 according to Zillow.com, an online real estate tracking database. The current housing market is still struggling to rebound from the 2008-2009 economic recession and building permits issued by the City declined by 40 percent from 2007 to 2008. Nearly 60 percent of San Luis Obispo householders are renters and according to the American Community Survey's 2007-2009 estimate, the median gross rent was over $\$ 1,100$.

Despite San Luis Obispo's unofficial "slow growth" policy, there is still plenty of space in which the City can grow and increase its housing stock. A City inventory of residential capacity conducted in 2009 revealed there are 640 vacant and underutilized parcels and nearly 800 additional acres within the Urban Reserve that could accommodate approximately 4,100 dwellings.

There are approximately 5,800 city residents that are eligible for affordable housing units in Entrada Ranch. These residents earn $50 \%$ or less of the Area Median Income and could potentially qualify for the low, very low, and extremely low residences that are built. This total number could be greater if people that currently work in SLO, but live elsewhere due to unaffordable housing costs, are included.

\section{San Luis Obispo Housing Element}

The San Luis Obispo Housing Element was updated in 2010 and includes the following basic objectives:

- Increase public awareness and understanding of the City's housing situation and goals to encourage public participation in addressing housing needs

- Provide a comprehensive document that includes goals, policies and programs to guide community efforts to meet housing needs through informed decision-making on land use and housing choices

- Develop more affordable housing and a wider variety of housing to meet the City's housing needs from January 1 , 2010 to December, 2014

- Track and document effectiveness of City programs in meeting housing needs, and evaluate opportunities for improving programs

- Enable the City to secure financial assistance for construction of affordable housing for very low-, low- and moderate income persons

. Full integration of environmental sustainability, "smart growth" and conservation strategies into housing policy.

(City of San Luis Obispo Housing Element, 2010)
The Entrada Ranch Development addresses these goals by educating stakeholders and the community on the project and need for affordable housing. It also provides a large contribution to reaching the Regional Housing Need Allocation while integrating sustainable design into the entire project through LEED for Neighborhood Development certification.

\begin{tabular}{|l|r|}
\hline Affordability Level & Number of Units \\
\hline Very Low & 37 \\
\hline Very Low and Low & 3 \\
\hline Low & 686 \\
\hline Low and Moderate & 47 \\
\hline Moderate & 31 \\
\hline Total & $\mathbf{8 0 4}$ \\
\hline
\end{tabular}

Figure 1.5 Existing Affordable Units in the City of San Luis Obispo, Source: City of SLO

\begin{tabular}{|l|r|}
\hline Affordability Term & Number of Units \\
\hline Indefinite & 689 \\
\hline 30 Years & 115 \\
\hline Total & $\mathbf{8 0 4}$ \\
\hline Figure 1.6 Affordability Term of Existing Units, Source: City of SLO
\end{tabular}

\begin{tabular}{|l|r|}
\hline Housing Type & Number of Units \\
\hline Apartment & 769 \\
\hline Condo & 7 \\
\hline Group & 0 \\
\hline Single Family & 22 \\
\hline Women's Shelter & 6 \\
\hline
\end{tabular}

\begin{tabular}{|c|c|c|c|}
\hline \multirow{2}{*}{$\begin{array}{c}\text { Income } \\
\text { Category }\end{array}$} & $\begin{array}{c}\text { New } \\
\text { Constructio } \\
\mathbf{n} \text { Need } \\
\text { (RHNA) }\end{array}$ & $\begin{array}{c}\text { Dwelling Units } \\
\text { Approved, } \\
\text { Under } \\
\text { Construction or } \\
\text { Built }\end{array}$ & $\begin{array}{c}\text { Remaining } \\
\text { Need } \\
\text { Dwelling } \\
\text { Units }\end{array}$ \\
\hline $\begin{array}{c}\text { Extremely-Low } \\
\text { (<31\% of AMI) }\end{array}$ & 185 & 8 & 177 \\
\hline $\begin{array}{c}\text { Very Low (31-50\% } \\
\text { of AMI) }\end{array}$ & 185 & 164 & 21 \\
\hline \begin{tabular}{c} 
Low (51-80\% of AMI) \\
\hline $\begin{array}{c}\text { Moderate (81-120\% } \\
\text { ogf AMI) }\end{array}$
\end{tabular}$\quad 259$ & 32 & 227 \\
\hline $\begin{array}{c}\text { Above Moderate } \\
\text { (over 120\% of AMI) }\end{array}$ & 665 & $1,033^{1}(665)$ & 253 \\
\hline Total Units & $\mathbf{1 , 5 8 9}$ & $\mathbf{1 , 2 7 9}(\mathbf{9 1 1})$ & $\mathbf{6 7 8}$ \\
\hline
\end{tabular}

Figure 1.8 Remaining Affordable Housing Need

Source: City of San Luis Obispo Community Development Department, 2010 1 No credit allowed for the number of units built that exceed RHNA. 


\section{ENTRADA RANCH}

\section{Location and \\ Surrounding \\ Amenities \& \\ Services}

2. The Site

The site is located off US

Highway 101, at 12165 Los

Osos Valley Road, a major

thoroughfare into the City

of San Luis Obispo (Figure

2.1). The project aims to

enhance this southern

gateway into the City.

This area of SLO

features many large-scale

commercial and retail

developments that can

support and serve a

project of this size. The

major developments

in the immediate

vicinity include: Irish

Hills Plaza and Prefumo

Creek Commons

with "big-box" retail,

several car dealerships

and a Marriot Hotel.

There are also many

local educational and

recreational services

such as schools, public

parks and public

transportation nearby

(Figures 2.2. and 2.3).

These amenities and

services make the

site very desirable

for future residential

development.

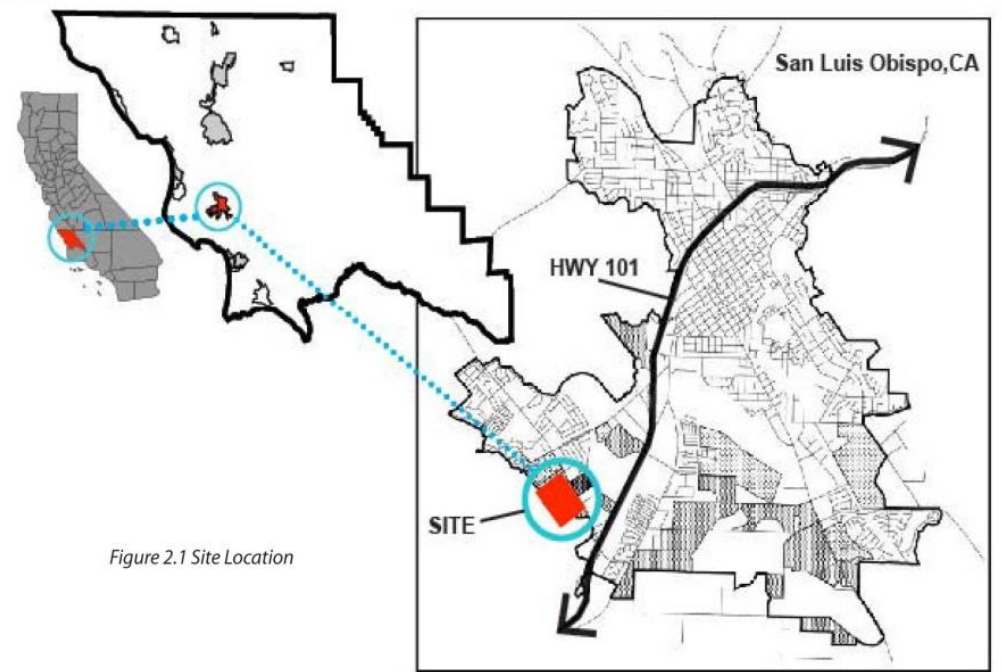

\begin{tabular}{|c|c|c|}
\hline Name & Service & Distance \\
\hline Fire Station 4, 1395 Madonna Road & Fire & $0.4 \mathrm{mi}$ \\
\hline New Frontiers & Grocery & $0.1 \mathrm{mi}$ \\
\hline Food 4 Less & Grocery & $1 \mathrm{mi}$ \\
\hline Spencer's Market & Grocery & $0.5 \mathrm{mi}$ \\
\hline French Hospital Medical Center & Hospital & $3.7 \mathrm{mi}$ \\
\hline Sierra Vista Regional Medical Center & Hospital & $5.4 \mathrm{mi}$ \\
\hline San Luis Obispo Library & Library & $3.3 \mathrm{mi}$ \\
\hline Irish Hills Natural Reserve & Open Space/Trails & $0.9 \mathrm{mi}$ \\
\hline Laguna Lake Park & Park & $1.6 \mathrm{mi}$ \\
\hline Laguna Hills Park & Park & $1.4 \mathrm{mi}$ \\
\hline Vista Lago Park & Park & $1.1 \mathrm{mi}$ \\
\hline Costco & Pharmacy/Grocery/Retail & $0.35 \mathrm{mi}$ \\
\hline Target & Pharmacy/Grocery/Retail & $0.25 \mathrm{mi}$ \\
\hline CVS Pharmacy & Pharmacy & $0.6 \mathrm{mi}$ \\
\hline U.S. Post Office, 1655 Dalidio Drive & Post Office & $1.1 \mathrm{mi}$ \\
\hline Route 4 Bus Stop & Public Transportation & $0.1 / 0.3 \mathrm{mi}$ \\
\hline Route 5 Bus Stop & Public Transportation & $0.1 / 0.3 \mathrm{mi}$ \\
\hline Downtown San Luis Obispo & Retail and Services & $3.1 \mathrm{mi}$ \\
\hline Laguna Village Shopping Center & Retail and Services & $0.5 \mathrm{mi}$ \\
\hline Irish Hills Shopping Center & Retail and Services & $0.25 \mathrm{mi}$ \\
\hline Perfumo Creek Commons & Retail and Services & $0.25 \mathrm{mi}$ \\
\hline Laguna Middle School & School & $1 \mathrm{mi}$ \\
\hline C.L. Smith Elementary & School & $1.2 \mathrm{mi}$ \\
\hline
\end{tabular}

Figure 2.2 Neighborhood Services 


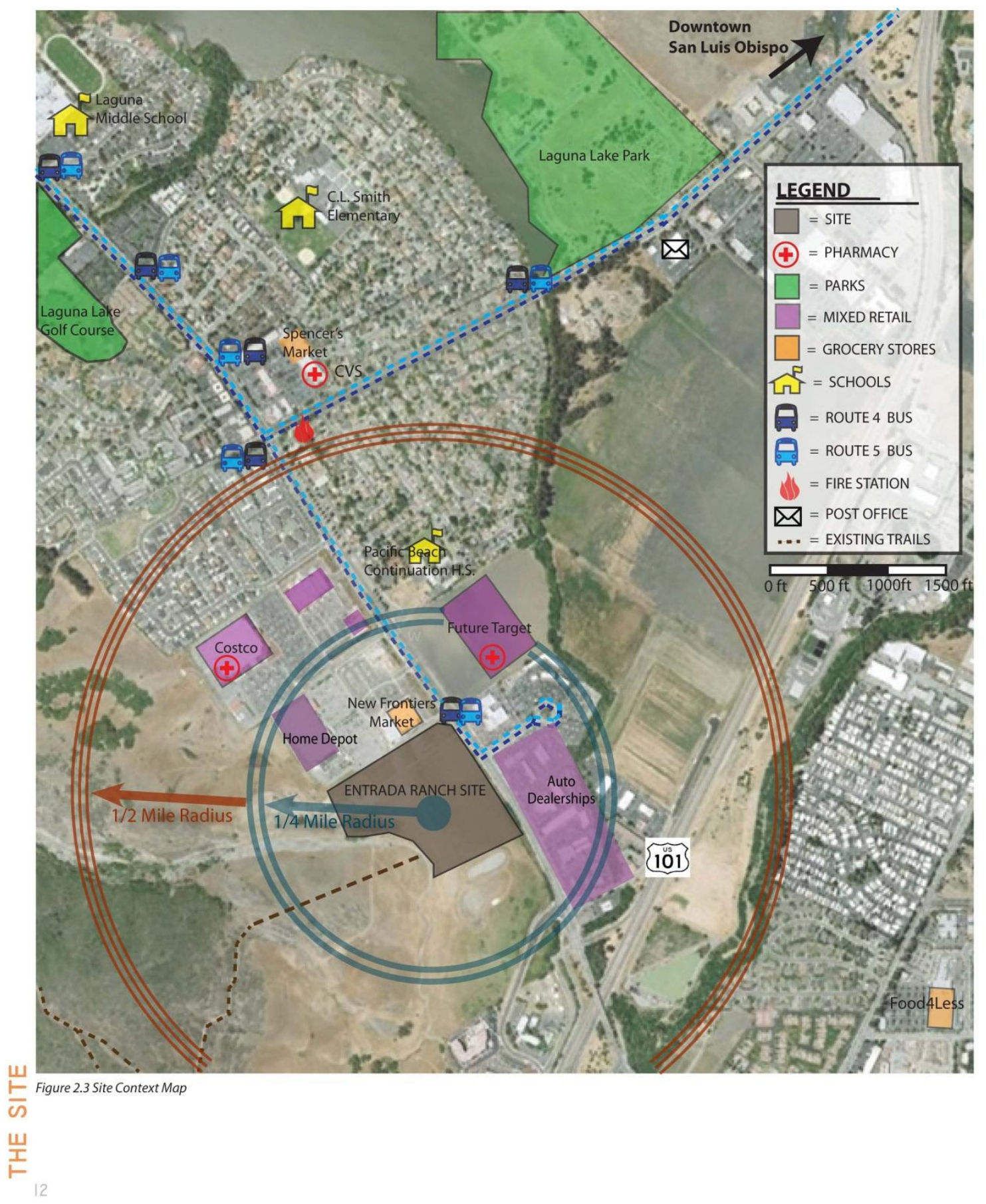




\section{Existing Site Conditions}

The proposed project is located adjacent to City of San Luis Obispo's southwestern boundary. The project site is less a mile from Madonna Road and South Higuera Street, two major local thoroughfares into and out of the City, and less than half a mile from Highway 101. Access to the site will be from Los Osos Valley Road via any of the three thoroughfares.

Currently the project site is at the foot of the Irish Hills and is undeveloped vacant land composed of wetlands and the Froom Creek, two important land features. There are approximately ten acres of wetlands that form a natural eastern boundary and buffer to Los Osos Valley Road while Froom Creek, which takes a "U" shape, forms a natural western boundary between the hillside and project area.

The land for the planned Entrada Ranch development is currently owned by PHC's developer-partner Madonna Enterprises. In exchange for the development fee and becoming a partner of the Entrada Ranch LP after syndication is completed, Madonna Enterprises is willing to donate the land. Due to the current ownership of the land and the desire of our developer-partner to build low-income housing on this site, there should not be any issue maintaining site control during the various approvals and subdivisions prior to construction.

A survey of the existing conditions reveals that approximately nine acres of the total 11.6 developable acres are composed of cropley clay and about 2.2 acres of Diablo and cibo clays. Cropley clays are usually found on alluvial fans, floodplains, and basins while Diablo and Cibo clays are found on hillsides. Given the mix of soil types and slow surface runoff properties of Cropley clay, the site is ideal for building housing.

\section{Environmental Review and Mitigation}

The project site contains areas that are delineated as wetlands pursuant to Federal and State standards. An Environmental Impact Determination of the project will be completed prior to development to ensure the built environment will not interfere with the wetlands. The site currently contains a storm water retention pond that serves the Irish Hills Plaza and was built with a holding capacity that will serve the Entrada Ranch development. The retention pond was built to the highest standards of the Army Corps of Engineers to comply with CEQA regulations (California Environmental Quality Act). The following permits will be collected prior to development to ensure minimal disturbance of wetlands:
- Department of Fish and Game 1600 Permit

- Permit from the Water Quality Control Board

- Nationwide permit from the Army Corps of Engineers

- National Pollutant Discharge Elimination System Permit Given the presence of the wetlands and natural water drainage on the site, PHC will properly mitigate and plan for future restoration of the sensitive habitats on the site. Some roads and all parking lots will be paved with pervious materials to minimize the amount of storm water runoff from impervious materials. There will not be any development located within the required setback of the wetlands and the project incorporates the natural environment into its design solutions thus reducing the overall impact of development on the land.

\section{Project Amenities}

Entrada Ranch amenities encourage a healthy lifestyle for its residents and includes several amenities to enhance the quality of life for the community while conserving the surrounding natural habitat. Future commercial development, a community center at the heart of Entrada Ranch, community gardens, and trail access will be connected by a centrally located and pedestrian-only axis. Through innovative streetscape design, the site will tie into the other nearby commercial amenities. Other strategies that contribute to the living experience at Entrada Ranch development include green design features that minimize human impacts on the built environment and a cultural preservation plan to adaptively reuse the structures on the historic Froom Ranch property to the Southwest of the project.

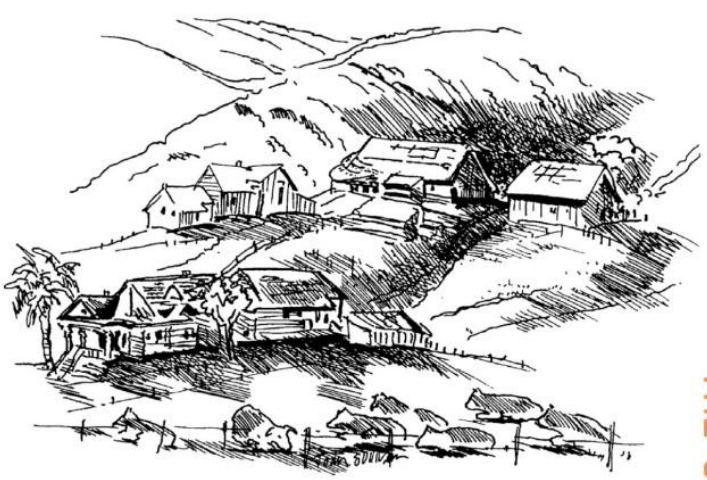

Figure 2.4 Sketch of the Historic Froom Ranch by local artist Joan Sullivan 


\section{ENTRADA RANCH}

\section{Meet the Team}

Stephan Jackson : Project Manager City and Regional Planning, Senior San Jose, CA

This is Stephan's 3rd year working on the Cal Poly BofA team. After his return from serving with the Peace Corps, he hopes to work in the field of advocacy planning and affordable housing.

Jenna Hahn: Planning Team City and Regional Planning, 4th Year Minors in Sustainable Environments and Anthropology \& Geograpahy Pleasanton, CA

Jenna has passions for social equity and outreach, environmental justice, and sustainability. After earning a Master's degree, she hopes to pursue an innovative career working with urban infill and international development focusing on public welfare, poverty, and climate change.

Hannah Edelsberg: Planning Team City and Regional Planning, Senior Minor in Sustainable Environments San Francisco, CA

Hannah has always had an interest in the social aspects of urban planning and spent most of her senior year at Cal Poly focusing on healthy community planning and housing. She hopes to work in the field of either affordable housing of public health planning in the Bay Area, and eventually receive her Master's degree in a related field.

Dan Findley: Planning Team Master of City and Regional Planning, 1st Yea Belle Mead, NJ

Dan has worked for a consulting company building communities in project areas throughout Peru, and was most recently a project manager for an affordable housing developer in San Francisco. Dan joined the Bank of America Low-Income Housing Challenge team as a planner, and will use this experience to prepare him for a career in affordable housing and community planning.

\section{Lisa Snyder: Design Team}

Architecture, 4th Year

Lebanon, $\mathrm{OH}$

Lisa serves as part of the design team working primarily on digital design work. Joining the team to expand upon the integrative process of design Lisa hopes to take her education and continue to grow in areas regarding historic preservation and architectural history.

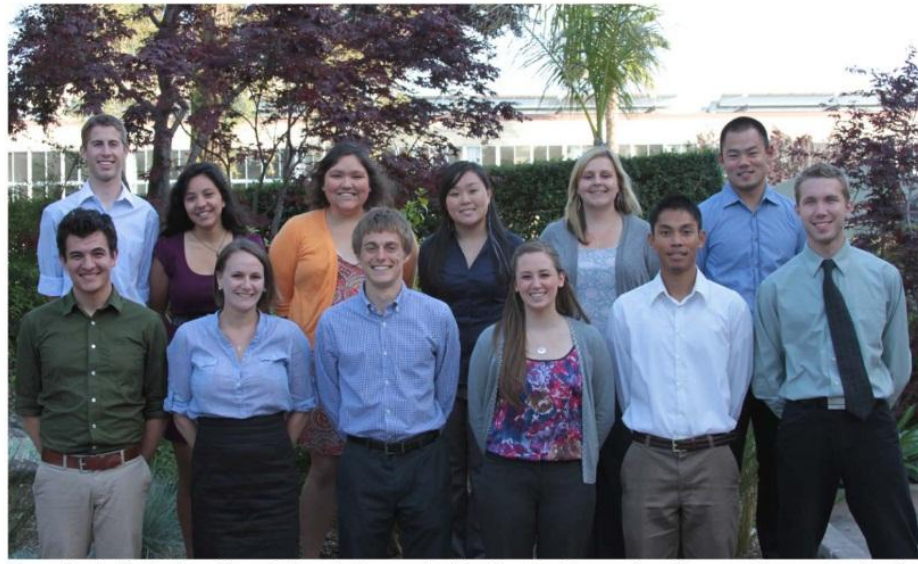

From Top Left: Andrew Nowak, Yesenia Fernandez, Lisa Snyder, Danette Lee, Shannon Thompson, Curtis Suda; From Bottom Left: Stephan Jackson, Hannah Edelsberg, Will Conner, Jenna Hahn, Dan Findley, Enrique lvers

Shannon Thompson: Design Team BARCH + Master of City and Regional Planning, 1st Year Santa Barbara, CA

Shannon has a passion for design and planning for those who are less fortunate. She wanted to be involved with the low income housing challenge in order to be a part of a team that would create a place that would give everyone the chance to have a roof over their head. In the future, she hopes to open her own planning and architecture firm specializing in both community spaces and low-income housing projects.

Yesenia Fernandez: Design Team Landscape Architecture, 3rd Year Belmont, CA

Yesenia joined the Bank of America LowIncome Housing Challenge team because, along with the opportunity to learn about low-income housing work, the project we took presented a great site for its design. While currently learning design, I will soon be studying sociology and I am excited fo the opportunities that my knowledge in both disciplines will bring.

Andrew Nowak: Design Team Landscape Architecture, 3rd Year San Jose, CA

As a Landscape Architecture student he has a strong passion for social and environmental justice and art. Andrew joined the team to future progress his interest and learn more about low-income housing. This collaborative involvement strengthened his interests in becoming a Landscape Architect and an ambition to design sustainable communities.
Will Conner: Finance Team Business Administration, Senio Los Altos, CA

Will intends to return to the Bay Area after graduating to begin work as a consultant for Ernst and Young.

Danette Lee: Finance Team Business Administration , 3rd Year Sunnyvale, CA

Danette joined the finance team to better understand the financing plans that go into building a development, especially with affordable housing. She one day hopes to work in a multinational corporation's real estate division.

Curtis Suda: Finance Team Senior, Business Administration, Senior Moraga, CA

Curtis plans to move to San Francisco upon graduation in June. Curtis has a strong interest in institutional real estate and hopes to one day form a REIT.

Enrique Ivers: Construction Construction Management, 3rd Year Sacramento, CA

Having lived abroad in Mexico and Uruguay for a number of years before coming to Cal Poly, Enrique enjoys the interpersonal aspect of construction that allows him to work with others and learn from their unique experiences. He hopes to work in mid-rise and highrise construction domestically, and eventually work abroad. 